\title{
EIGHTH REPORT
}

\section{THE COMMISSIONERS}

EXHIBITION OF 18.51,

m भा!:

RIGHT HON. WINSTON CHURCHILI, M.P.

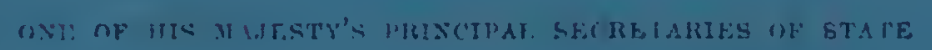

LONDON:

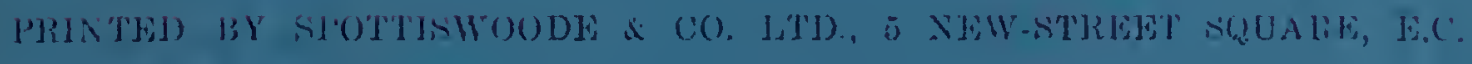





ROYAL COMMISSION FOR THE EXHIBITION

1851.

KENSINGTON GORE ESTATE

1910. 



\section{EIGHTH REPORT}

$\mathrm{OH}$

\section{THE COMMISSIONERS}

FOR THE

\section{EXHIBITION OF 1851,}

TO THE

RIGHT HON. WINSTON CHURCHILL, M.P.

ONE OF HIS MAJESTY'S PRINCIPAI, SECRETARIES OF STATE

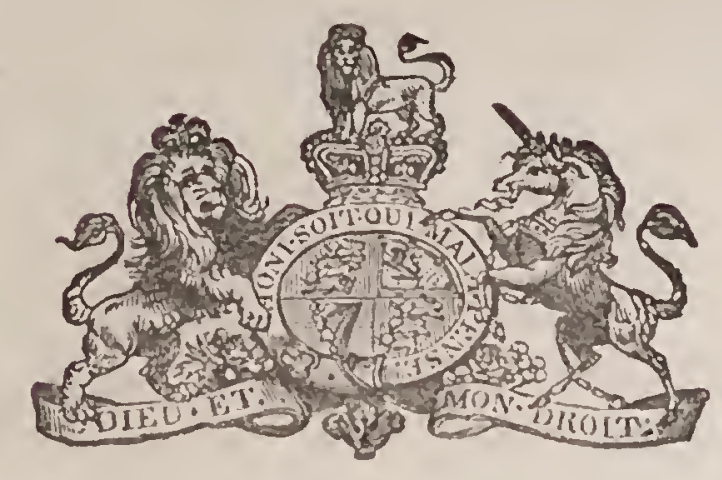

LONDON:

PRINTED BY SPOTTISWOODE \& CO. LTD., 5 NEW-STREET SQUARE, E.C. 


\section{TABLE OF CONTENTS.}

REPORT

Page

Appendix.

A.-List of the Mrumers of the Royal Commission since its Formation ... _.. i34

B.-Dend of Conveyance to H.M. Governarent of the Sitre sontl of the Taprirata

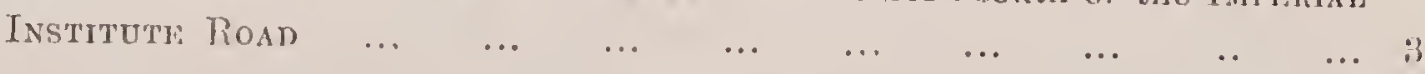

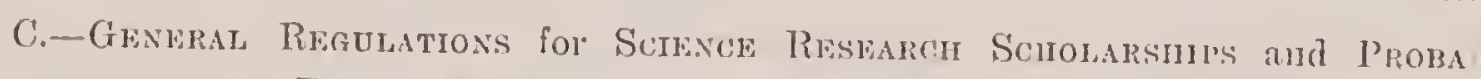

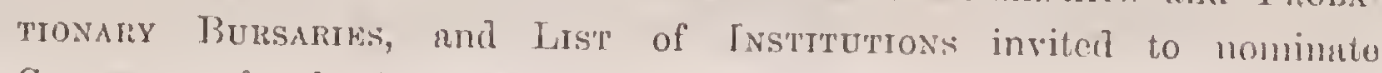

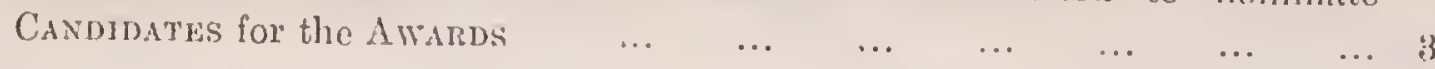

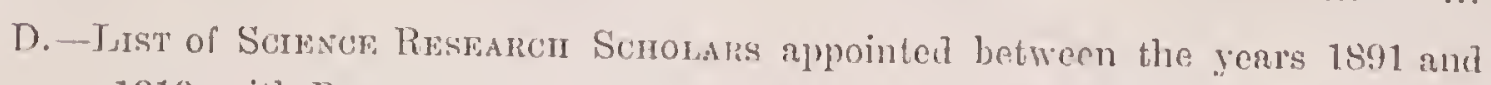

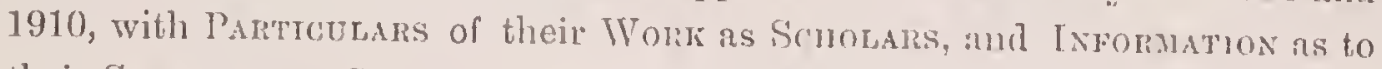

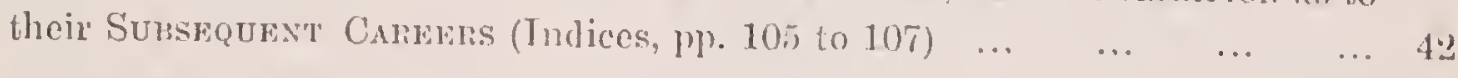

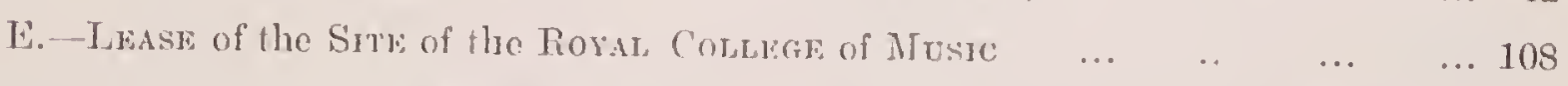

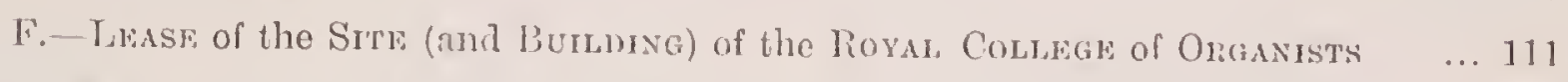

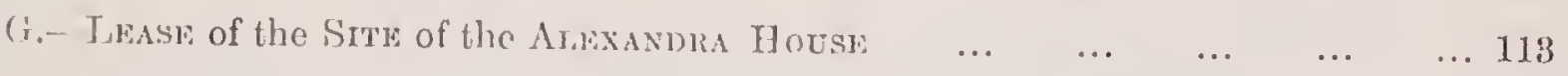

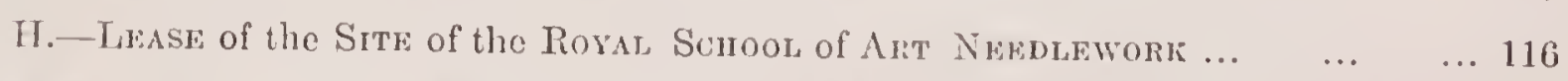

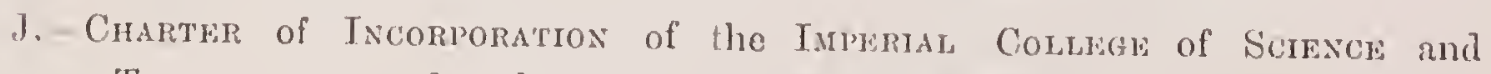
TrehNology, and subsequent OrDFRs in Couxila nllowing amendment $\begin{array}{lllllllllllll}\text { of } \text { sime } & \ldots & \ldots & \ldots & \ldots & \ldots & \ldots & \ldots & \ldots & \ldots & \ldots\end{array}$

K.- Lmasi: of the Sitres of the Impeniat College of Schincis and Tronnology ... 136

L. - Mramoliat addressed to the President of the lionkd of Foucation in favour of the Provision of More Suituml: Accomsondion for the Nationat.

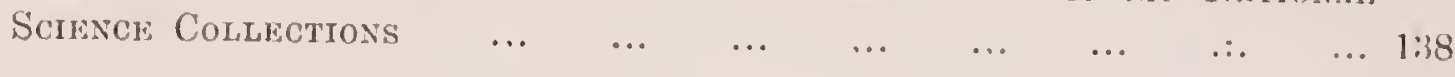

M.-Account of the Receipts and Payuents of the lioyal Comission from

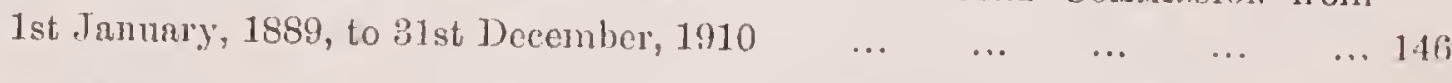

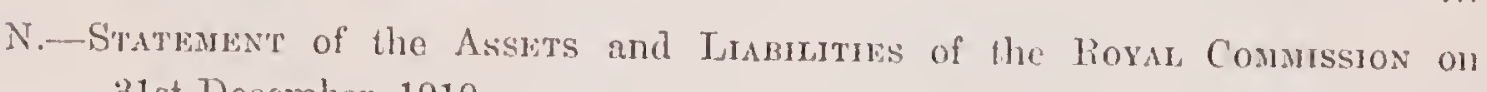
31 st December, 1910

... 145

Pluns.

Plan of the Fensington Gore Estate as at present appropriated... To face Title Puge.

Phan of the Properties composing the Fexsington Gore Estatr, as originally purchased by the Commisstonfrs

At end of lolume. 



\section{COMMISSIONERS FOR THE EXHIBITION OF 1851,}

TO THE

RIGHT HON. WINSTON CHURCHILL, M.P.

One of His Majesty's Principal Secretaries of State.

SIR,

Since the issue of our last Report on 23rd July, 1889, we have regularly submitted to the Home Office for presentation to the Sovereign particulars of the principal transactions in which we have been engaged from year to year, as well as our annual financial statements, and in conformity with the provisions of the Supplemental Charter, which Her Majesty Queen Victoria was graciously pleased to grant to us on 2nd December, 1851, we have now the honour to transmit to you, for the approval of His Majesty the King, a summary of those transactions in this, the Eighth Report of our proceedings.

During the interval that has elapsed since the issue of our Seventh Report the nation has been twice plunged into heartfelt mourning by the loss of the reigning Sovereign.

The gracious regard which Queen Victoria evinced for our pro- Queen ceedings was continued to the end of her reign, and it is a matter for Victoria. much satisfaction that Her Majesty was able to witness the gradual realisation of the great conceptions which the Prince Consort, our illustrious First President, bequeathed to us after a life spent in ceaseless activity in the cause of Science and Art.

King Edward the Seventh, after acceding to the throne, graciously King continued to extend to our proceedings the same interest he had Edward. shown during the thirty-one years in which as Prince of Wales he had acted as President of our body. His complete sympathy with the ideals of his honoured father was an influential factor in the success that attended his long tenure of the Presidency. 
King

George.

Prince

Arthur of Connaught.

Changes in Commission.

After the accession of His late Majesty in 1901, His Royal Highness the Prince of Wales (now King George the lifth) became our President, and his intimate knowledge of our work and his wise counsels and judicious advice have been of the greatest value to the Commission. We feel assured that as Sovereign His Majesty will deign to continue to us his gracious guidance and support.

His Majesty's accession to the Throne has necessitated the election of a new President, to which office we have appointed, with the approval of the King, His Royal Higlmess Prince Arthur of Connaught, thus securing a continuance of the direct interest in our labours that has always been evinced by the Royal Family.

Since our last Report, we have, under the power conferred by our Supplemental Charter, elected as Commissioner's* : His Royal Highness the Prince of Wales (now our gracious Sovereign), the Duke of Norfolk, the Duke of Fife, the Duke of Argyll, the Earl Spencer, Viscount Esher, Lord Kelvin (since deceased), Lord Rayleigh, Lord Welby, Lord James of Hereford, Lord Courtney of Penwith, the Right Hon. Sir Henry Campbell-Bannerman (since deceased), the Right Hon. Herbert Asquith, the Right Hon. Thomas Henry Huxley (since deceased), Lieut.-Colonel the Right Hon. Sir Fleetwood Edwards (since deceased), Lieut.-Colonel the Right Hon. Sir Arthur Bigge, the Right Hon. Sir Francis Mowatt, the Right Hon. Sir Edward Walter Hamilton (resigned 1908, and since deceased), the Right Hon. Sir Henry Roscoe, the Right Hon. Sir George Murray, Baron Ferdinand de Rothschild (since deceased), Sir John Everett Millais (since deceased), Sir Charles Lister Ryan, Sir Norman Lockyer, Sir Archibald Geikie, Sir Robert Morant, Sir Arthur Rücker, Dr. William Garnett, Dr. Richard Tetley Glazebrook, and Mr. Francis Ogilvie.

We have to record the death of the following members of the Royal Commission: His Royal Highness the Duke of Edinburgh, His Royal Highness the Duke of Cambridge, His Serene Highness the Duke of Teck, the Duke of Sutherland, the Marquis of Salisbury, the Marquis of Ripon, the Earl Granville, the Earl of Selborne, the Earl of Carnarvon, the Earl Spencer, Viscount Wolverhampton, Viscount Sherbrooke, Lord Playfair, Lord Thring, Lord Aberdare, Lord Sandford, Lord Leighton, Lord Herschell, Lord Kelvin, the Right Hon. William Ewart Gladstone, the Right Hon. Sir Henry Campbell-Bannerman,

* A complete list of the Commissioners appointed since the formation of the Commission will be found in the Appendix (A, page 34). 
the Right Hon. Hugh C. E. Childers, the Right Hon. Anthony John Mundella, the Right Hon. Thomas Henry Huxley, General the Right Hon. Sir Henry Ponsonby, Lieut.-Colonel the Right Hon. Sir Fleetwood Edwards, Admiral of the Fleet Sir Alexander Milne, Baron Ferdinand de Rothschild, Sir William Anderson, Sir Richard Wallace, Sir Sydney Waterlow, Sir Frederick Bramwell, Sir John Everett Millais, and Mr. Thomas Field Gibson.

We desire especially to place on record our appreciation of the long and devoted services of the late Lord Playfair, and our sense of the great loss we sustained by his death in the year 1898. As Dr. Playfair, he acted as Special Commissioner in comnection with the Exhibition of 1851, and from that time became an active leader in the movement for improving industrial education in this country. After his election as a member of the Royal Commission in 1869, he took a prominent part in its executive duties, and for several years acted as Deputy Chairman of the Board of Management. He also acted as Honorary Secretary to the Royal Commission from 1883 to 1889, and, mainly owing to his skill in conducting our aflairs during that period, the previous deficit in our income was converted into a surplus of more than $\{5,000$ a year, with a prospect of considerable increase, which has since been realised. The scheme of Science Research Scholarships, to which, as will hereafter be shown, we have devoted a considerable portion of our surplus income, originated with Lord Playfair, and, for the first five years of its working, he, as Chairman of the Scholarships Committee, took upon himself the burden of the management. On Lord Playfair relinquishing his more active duties in 1896, Sir Henry Fowler (afterwards Viscount Wolverhampton) was appointed Deputy Chairman of the Board of Management, and Sir Henry Roscoe Chairman of the Scholarships Committee.

His Royal Highness the Prince Christian of Schleswig-Holstein Prince resigned his position of Chairman of the Board of Management in Christian 1904, after having discharged the duties of that office for no less than twenty-three years. His services during that long period were of inestimable value to the Commission, and his retirement from the executive of the Commission due to the increasing number of his public engagements caused the greatest regret to our whole body.

His Royal Highness was succeeded as Chairman of the Board of Succeeded Management by the late Lord Wolverhampton, who, to our great by Viscount regret, in the early part of last year, was compelled by failing hampton. health to relinquish that post. His recent death following so closely on his retirement from public affair's we deeply deplore, and 
we cannot refer to the loss we have thus sustained without bearing testimony to his unremitting zeal and assiduous interest in our work, for which we owe him a profound debt of gratitude. No details of our work were too minute for his consideration, and during the twenty-one years in which he was closely associated with the Board of Management he brought to bear upon the affairs of the Commission an administrative ability which has done much to bring our deliberations to a successful issue.

Viscount Esher.

Death of Lord Thring.

Lord Kelvin.

Sir Edward Hamilton.

Sir Arthur Ellis.

Sir Arthur Bigge elected Secretary.

His resignation and appoint. ment of now Secretary.
An his auccessor in the office of Chairman we have been fortunate enough to secure the services of Viscount Esher, who for several years has taken an active part in the duties of the Board of Management.

General Sir Dighton Probyn was elected Treasurer of the Royal Commission in 1896 in succession to the late Lord Aberdare.

By the lamented death of Lord Thring in 1907 we were deprived of the assistance of a member of our body who had always taken a conspicuous part in the management of our affairs since his election in 1861 .

The valuable services rendered by the late Lord Kelvin during the seventeen years in which he acted on the Commission, especially in connection with the Science Research Scholarships Committee, of which he was an original member, deserve our grateful acknowledgment.

We are specially indebted to the late Sir Edward Walter Hamilton for his careful attention to our finances during the time he served on the Board of Management prior to his resignation in 1908.

We sustained a severe loss through the death of Major-General Sir Arthur Ellis in 1907. Originally appointed a Commissioner in 1877, he resigned his membership in 1889 to become our Secretary, the duties of which office he discharged with signal advantage to the Commission until the day of his death.

On the death of Sir Arthur Ellis, Lieut.-Colonel the Right Hon. Sir Arthur Bigge, who had previously been an active member of our Board of Management, was elected Secretary. During his tenure of this office he displayed conspicuous ability, and it was with much regret that we learned in July last that the calls upon his time would prevent him from giving us the benefit of his valuable services in the future. We reluctantly accepted his resignation and elected in his place Mr. Evelyn Shaw, who has served us as Assistant Secretary for the past six years. 
We mentioned in our last Report that in our dealings with the Kensington Gore Estate, we had kept in mind the probable requirements of His Majesty's Government for buildings connected with Science and the Arts, and had accordingly reserved for such requirements about $4 \frac{1}{2}$ acres of land on the south of the Imperial Institute Road. In July, 1888, we had addressed a letter to the Lords of the Treasury offering to convey this plot, which was of the estimated value of $£ 200,000$, to the Government for the sum of $£ 70,000$ on condition that it should be permanently used for purposes connected with Science or the Arts. We had pointed out that if the Government should accept this offer, and should also exercise their option to purchase the freehold of the central portion of the south Arcades, then in lease to them at a rent of $£ 1,500$ a year, they would become possessed of a compact piece of ground north of the Natural History Museum sufficient for a site for a Patent Museum or other public buildings.

In the spring of 1890 the Government accepted this offer, and at the same time agreed to purchase for the sum of $₫ 30,000$ the freehold of the building in question.

The necessary vote having been passed by the House of Commons, the purchase was completed on the 31st March, 1890, and the purchase money was applied in reduction of the mortgage debt as hereafter mentioned. The conveyance * provided that the property should be permanently used for purposes connected with Science or the Arts; but that the Government should be released from the covenant contained in the conveyance, made in 1864, of the site of the Exhibition of 1862, restricting its use to purposes connected with Science or the Arts, as far as such covenant applied to the frontage in Queen's Gate, lying between the Commissioners' estate and the boundary of the grounds of the Natural History Museum, a plot about 240 feet in length.

The Government have not, however, availed themselves of the removal of this restriction, and we understand that it is their intention to reserve this plot of land for the future requirements of the Board of Education in connection with Science and Art.

Since the purchase was effected, the Government have devoted a New buildportion of the site abutting on the Imperial Institute Road to the new $\begin{gathered}\text { ings- } \\ \text { Physical }\end{gathered}$ buildings containing the Physical and Chemical Laboratories of the and Chemical

* A copy of the Conveyance will be found in the Appendix (B, p. 36). Laboratories, \&c. 
Imperial College of Science and Technology, and the Science Tibrary. At the north-east corner they have erected a building for the Meteorological Office, the ground floors of which accommudate the District Post Office, which hal been established since the year 1872 in temporary premises in Lxhibition Road. The remaining portion of the site has been occupied by buildings, mainly of a temporary character, under the control of the Board of Education. We have, however, recently learned that the Government hope shortly to erect a permanent building for the National Science Collections on a portion of this site as indicated in the plan attached to this Report (facing tille-page). It is contemplated that the building will have a frontage on Exhibition Road between the new Post Office on the north and the Gardens of the Natural History Museum on the south, and will extend in a westerly direction along the north of the Natural History Museum as far as Qucen's Gate.

If this plan be carried out, the whole of the land lying between the Physical and Chemical Laboratories of the Imperial College and the Natural History Museum will be fully developed.

Science

Scholarships.

Awarded for research.

We stated in our last Report that we had resolved to allot an annual sum of not less than $\$ 5,000$ a year towards the establishment of scholarships, for the purpose of aiding the development of scientific culture and technical training in the manufacturing districts of the country, as it appeared to us that scholarships intended to enable students in provincial colleges of science to extend their studies would be the best means of recognising the claims of the provinces to participate in the resources at our disposal.

A Committee of gentlemen, especially conversant with the working and needs of scientific education, was thereupon appointed, with the late Lord Playfair as Chairman, to prepare a scheme for the distribution and regulation of the scholarships, so that they might be supplementary to and not in competition with scholarships provided by the Government or public bodies or by private endowment. This Committee pointed out at an early stage in its proceedings that very little would be gained by our action unless the scholarships awarded differed from those already existing, and that therefore they should be of a higher order, and awarded for research in the experimental sciences bearing upon the industries.

The recommendations of this Committec received our unanimous approval, and we resolved to adopt them as embodying the principles on which the scholarships should be founded. 
Although it was originally intended to confine the award of these scholarships to students of provincial colleges, it wis found on more detailed consideration that it would be desirable to extend Extension of scheme to the the benefits of the scheme to the colonies, and in the selection of universities and colleges to be invited from time to time to nominate candidates certain colonial institutions were included where special attention is given to scientific instruction. The scheme was subsequently extended to include further institutions in the Colonies, and one in the Metropolis. A list of the institutions included in the scheme showing the manner in which the nominations are distributed will be found in the Appendix (C, page 41).

As an epitome of the general regulations which have governed the award and tenure of our scholarships since their establishment in 1891 is given in the Appendix (C, page 38) it will be enough here to explain that these scholarships are awarded to students who have passed through a university curriculum and have given distinct evidence of capacity for original research, to enable them to continue the prosecution of science, with a view of aiding its advance, or its application to the industries of the country.

The scholarships are of the amnual value of $£ 150$, and are ordinarily tenable for two years, the continuation for the second year depending on the reports of the scholars' first year's work being satisfactory to the Scholarships Committee. The Committee may renew a limited number of the scholarships for a third year, where they are of opinion that the renewal is likely to result in work of scientific importance. The scholarships are annually awarded to persons primarily recommended by the governing bodies of the institutions to which nominations are from time to time allotted, and the holders are required in the absence of special circumstances to proceed to an institution other than that by which they were nominated, the institution selected and the work proposed to be carried out being subject to the approval of the Scholarships Committee.

In 1900 our scheme of scholarships was supplemented by the Proestablishment of a system of Probationary Bursaries, to be awarded in certain cases where the nominee of an institution appears not to be immediately qualified for a scholarship, but gives promise of becoming so after a year's experience of research work. Under the regulations drawn up for the award of these bursaries, the applicant has to satisfy the Scholarships Committee that he is not in a position to undertake post-graduate work without assistance, and 
that there is not available for him any scholarship or similar fund at the disposal of the university or college.

Their A bursary is tenable for one year, and is of the value of $£ 70$, and value. the holder may be advanced to a scholarship at the end of his term, if, in the opinion of the Scholarships Committee, his work during his tenure of the bursary is sufficient to entitle him to the award. A list of the regulations for probationary bursaries is given in the Appendix (C, page 39).

Satisfactory There will also be found in the Appendix (D, page 42) a complete results of scheme. list, in chronological order, of the scholars and bursar's appointed since the establishment of the scheme in 1891, with brief particulars of their work as such, and information regarding their subsequent careers. 'T'his list, containing as it does the names of so many persons who have already distinguished themselves in their professions, furnishes ample evidence of the educational value of the scholarships. Moreover, we believe that for the majority of those whose careers have been attended with so much success, the scholarship came at a time when the special opportunities it aftorded had a marked effect in raising the level upon which the scholar could employ his talents in the advancement of science. Indeed, many of the scholars themselves have informed us that, had it not been for the scholarship, they would have been compelled, for want of financial assistance, to discontinue the prosecution of science or to take up a position in which their natural ability would have found but little scope. We have further received the strongest evidence from persons interested in the progress of science throughout the empire of the beneficial influence which our scholarships have exerted, not only on the scholars themselves, who have obtained high positions in pure and applied science, but upon the colleges and universities which have benefited by our scheme, inasmuch as the scholarships have tended to raise the standard of the teaching in these institutions.

The successful working of our scheme, which was the first of its kind to be established in England and has led the way to the further provision of similar endowments in this country and abroad, confirms us in the belief that we are justified in continuing to dispose of a portion of our income towards this object.

We cannot omit to mention the valuable services rendered to us in an honorary capacity by the past and present members of the Scholarships Committee, which, presided over first of all by Lord Playfair, and then by Sir Henry Roscoe, has always 
discharged its duties in a manner deserving of our special acknowledgment.*

In our last Report we described in detail the steps which had been Royal taken to establish the Royal College of Music on our estate in the year 1882. We explained that the new College had been created College of Music. as the result of a movement initiated by His late Majesty, when Prince of Wales, to supersede and develop the work, on a permanent basis, of the National Training School of Music, which had occupied, since 1876, the house on our estate given by the late Sir Charles Freake to the Prince of Wales as our President in trust for the nation. We referred to our decision to contribute the annual sum of $£ 500$ to the funds of the College, and stated that in view of the success which had attended the College and the insufficiency of accommodation afforded to the growing number of its pupils we had resolved to allocate a site, 200 feet square, on the northern portion of our estate, for a new building, the funds for the erection of which had been generously provided by Mr. Sampson Fox, of Leeds.

Shortly after the issue of our Report, Sir Arthur Blomfield's design for the elevation of the building was approved by us, on the advice of Mr. Waterhouse, R.A. The first stone of the building was laid by the Prince of Wales on 8th July, 1890, and on its completion in 1892 we granted a lease $\nmid$ of the site for 999 years at a ground rent of $£ 5$ a year, the College being permitted to retain possession of the former premises as long as they should be required.

Since our last Report we have been represented on the Council of the College by the late Mr. Childers, the late Baron Ferdinand de Rothschild, and, since 1899, by Earl Spencer.

In March, 1903, the Council of the Royal College of Organists addressed to us a memorial asking for a lease of the house previously occupied by the Royal College of Music, and offering to

The Royal College of Organists.

* Past and Present Members of Scholarships Committeo: Lord Playfair, 1890-1897, Chairman 1890-1896; Mr. Nundella, 1890-1897; Sir Henry Roscoe, since 1890, Chairman since 1896; Lord Felvin, 1890-1907; Professor Huxley, 1890-1896; Sir Norman Lockyer, since 1890; Dr. William Garnett, since 1890; Lord Rayleigh, since 1896; Lord Comrtney of Penwith, since 1898; Sir Arthur Rücker, since 1898; Dr. W. J. Russell, 1898-1908; Professor W. E. Ayrton, 1904-1908; Professor J. N. Collie, since 1904; Sir Archibald Geikie, since 1906; Professor J. D. Cormack, since 1906 ; Dr. R. T. Glazebrook, since 1908; Dr. Horace Brown, since 1908.

† A copy of the lease to the Royal College of Music will be found in the Appendix (E, page 108). 
render it suitable for their purpose by effecting alterations estimated to cost $£ 3,000$.

The work of the College appeared to us to be in complete accord with the objects for which the building had been originally erected by Sir Charles Freake, and we considered that the provision on our estate of a home for the College would come within the scope of our trust. On the completion, therefore, of the proposed improvements a lease* of the premises was granted for 99 years at a rent of $£ 1$ a year, on condition that the building should be used only for the purposes of the College. Alexandra Our last Report gave an account of the erection, through the Association. munificence of Sir Francis Cook, of the Alexandra House, a home for female students attending various institutions on the estate. The formation of a governing body and the mode of government were then under consideration and it was stated that, on these matters being settled with our approval, we should be prepared to grant a lease of the building and its site at a nominal rent and on suitable conditions. The scheme for the government of the Institution having subsequently received the approval of Her Majesty Queen Alexandra (when Princess of Wales) as President, of Sir Francis Cook, as Founder, and of ourselves, a lease $\nmid$ was granted in 1894 for a term of 999 years at a rent of $£ 5$ a year. The institution was incorporated under the Companies Acts as a Company limited by guarantee, with the name of the Alexandra House Association, and its general management was vested in a Council representative of the several parties interested and including three members appointed by ourselves.

The House has accommodation for one hundred students, who are comfortably provided for at the inclusive cost of about $f 66$ a year.

Since its foundation in 1887 the House has received 1,290 students from all parts of the Empire, and the long list of candidates for admission promises a continuance of its prosperity.

We cannot close our reference to this institution without recording our sense of gratitude to the Bishop of Peterborough, the late Baron Ferdinand de Rothschild and the late Sir Joshua Fitch, as our original * A copy of the lease to the Royal College of Organists will be found in the
Appendix (F, page 111). t A copy of the lease to the Alexandra House Association is given in the
Appendix $(G$, page 113). 
representatives on the Council of the Alexandra House; and to Lord Farquhar, Canon Pennefather and the late Sir Fleetwood Edwards, who in 1909 accepted the invitation of His Royal Highness the Prince of Wales to represent our body on the Council for a further term of five years. Sir Caspar Purdon Clarke has been appointed to fill the vacancy occasioned by the recent death of Sir Fleetwood Edwards.

Since our last report, our financial arrangements with the Corporation of the Royal Albert Hall have received careful consideration, and we are glad to report that a settlement has been arrived at, which is satisfactory both to the Corporation and to ourselves.

At the time our last report was issued there was outstanding a a sum of $£ 4,000$ advanced by us to the Corporation in 1876 to pay off the debt then due for the construction of the Hall.

In 1898 we provided the sum of $£ 7,566$ for the construction of a new south entrance, necessitated by the removal of the conservatory of the Royal Horticultural Society and of the northern ends of the Arcades, which, during their existence, formed a convenient entrance for visitors to the Hall approaching from the south side. Two-fifths of this expenditure was regarded as our share of the cost of the work and the remaining three-fifths, which amounted to $£ 4,540$, was treated as a loan to the Corporation.

We pointed out in our last report that the Act of Parliament passed in 1876, which authorised the annual levy of a seat rate, not

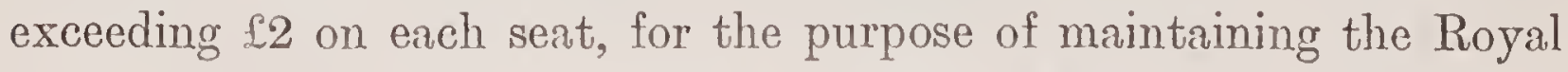
Albert Hall, had imposed on us a heavy liability in respect of our 800 seats in the Hall. This liability was slightly reduced by the proportion of the annual profits derived from letting the Hall which we received from the Corporation in return for their use of our seats, but even so, the net charge falling upon us was unduly heavy, seeing that the Hall was not, in our opinion, exclusively used for such purposes of public interest as could be considered to justify the annual application of our funds towards its support.

Our negotiations with the Corporation, which had extended over Financial several years, were brought to a definite issue in 1908, when the following agreement was made:--

The Corporation released us from all liability for seat rate as from 31st December, 1908, and we assigned our 800 seats to the Corporation for the remaining period of their lease of the Hall.

In return for the loss of income to the Corporation entailed by this 
arrangement, we relieved the Corporation of all liability in respect of the two loans already referred to, amounting together to $£ 8,540$, and we undertook to provide for the cost of further works connected with the completion of the south entrance to the Hall, and the construction of two vaults under the adjacent roadway, amounting to $£ 3,505$, treating two-fifths of this sum as our share of the expenditure and the remaining three-fifths as a loan to the Corporation, to be repaid in five annual instalments with interest at 4 per cent. The works in question have since been completed, and the Corporation have repaid to us two instalments of the loan, which became due in January, 1910 and 1911.

Imperial Institute.

Contribution to Research Depart. ment.

Transference of Imperial Institute to H.N. Govern. ment.

In our last Report we presented an account of the establishment of the Imperial Institute, and stated that we had appropriated nearly 7 acres of our land as a site for the building which was then in course of erection. Shortly after the opening of the building by Her Majesty Queen Victoria on 10th May, 1893, the Executive Committee of the Institute approached our body with a view to enlisting our support in the creation and maintenance of a department where the investigation and testing of the natural products of India and the Colonies could be carried on. As it seemed to us that such a department would have for its purpose the extension of the influence of science upon productive industry and would therefore come within the scope of our charter, we resolved to make an annual contribution of $£ 260$ for five years to be applied towards the salary of an investigator and assistant in the research laboratory. After the department had been in operation for the space of two years, and we had satisfied ourselves of the importance and value of the work conducted in the laboratory, we increased our annual contribution to $£ 1,000$, and further to $£ 2,000$ in 1898 and in each of the following years, until 1905, in which year the grants were to cease in accordance with a resolution passed in 1904 .
By an Act of Parliament which came into operation on lst January, 1903, the Imperial Institute was transferred to, and the control of the research department passed into the hands of, H.M. Government. In these circumstances, and in view of our previous determination that the grants should cease at the end of 1905, we did not consider ourselves called upon to continue our support to the laboratory, towards the expenses of which we had contributed a total sum of
$£ 18,520$. 
At the time of our last Report the Royal School of Art Needlework continued, on payment of a rent of $£ 236$ a year, in possession of temporary buildings in Exhibition Road, which it had occupied since its establishment in 1874.

In February, 1892, Her Royal Highness the Princess Christian of Schleswig-Holstein, the President of the School, addressed to us a letter asking for a grant of a site for a permanent building for the School, and suggesting as suitable for the purpose a piece of land at the corner of the Exhibition and Imperial Institute Roads. In consideration of the important work which the School was carrying on in its own department of art, in which it was recognised as a leader both in this country and abroad, we resolved to offer the Executive Committee of the School the land referred to, which was valued at $£ 18,120$, on a lease for 999 years at a ground rent of $£ 200$ a year.

The cost of a building commensurate with the importance of the Advance of site was estimated at $£ 32,000$, but for want of the necessary funds, for new building operations were deferred for several years. In March 1898 building. we learned that the Executive Committee of the School had succeeded in raising a building fund sufficient only to enable them to proceed with a portion of the design, and recognising that it would be desirable to ensure its completion without further delay we agreed to advance the necessary funds for the purpose. Our advances, amounting to $£ 20,000$, were secured, as to $£ 16,000$ by charging a redeemable rent of $£ 480$ a year, and as to $£ 4,000$ by a mortgage at 3 per cent. interest on the land and building; and on the completion of the building in 1901 a lease* was granted as from the 1st of September of that year. Arrangements were also made with our approval to underlet a portion of the building to the City and Guilds of London Institute for a term of twenty-one years at a rent of $£ 600$ a year, thereby providing an additional security for the payment of the interest on our loan.

In our last Report we stated that our Eastern and Western Eastern Exhibition Galleries, which had been built for our scheme of Annual and International Exhibitions of the Fine Arts and recent Scientific Exhibition Inventions held during the years 1871 to 1874 , were under lease to Galleries. the Government at rents amounting to $£ 3,000$ a year. The Eastern Galleries were occupied by the India Museum and the Western Galleries by portions of the collections under the charge of the Department of

* A copy of the lease to the Royal School of Art Needlerwork is given in the Appendix (H, page 116). 
Science and Art. We referred to certain improvements that were being made to the Galleries by continuing them at the south ends up to the Imperial Institute Road and by building entrances both at the south ends and at the north ends abutting on the Prince Consort Road, which we had decided to construct across the upper portion of the main square of our estate. These improvements were ultimately completed at the joint expense of ourselves and of the Organising Committee of the Imperial Institute in accordance with the terms of their lease.

In the year 1890 we had under consideration a proposal for the establishment in our Eastern and Western Galleries of a representative collection of works of Fine Art of the British School on the general lines of the Musće de Luxembourg in Paris. Although the scheme was eventually abandoned by the Government, we refer to the subject here, as our desire to secure the establishment on our Estate of the British Art Collection led us to adopt a suggestion for connecting our Eastern and Western Galleries by a communicating gallery. We had disposed of all the land lying between the two Galleries with the exception of a piece from 9 feet to 10 feet wide at the south of the site

Contribu-

tion to

Imperial Institute for communicating gallery.

Lease of Galleries to H.M. Government.

granted to the Royal College of Music. We had, therefore, to approach the Organising Committee of the Imperial Institute, whose co-operation in the scheme was required in order that the necessary passage between the two ranges of Galleries might be constructed on a portion of the site of the Imperial Institute adjoining the narrow strip in our possession. As the result of our negotiations, the Organising Committee undertook, with the assistance of a grant from us of $£ 3,000$, and of a lease of the strip of land on the south side of the Royal College of Music, the erection of a cross gallery, 25 feet wide, connecting on its upper floor our Eastern and Western Galleries. The Committee also arranged to lease the upper floor to His Majesty's Government for a term of years corresponding with the lease of the Eastern and Western Galleries. As soon as this provision had been made for the erection of the cross gallery, we executed a lease of our Eastern and Western Galleries, and of the adjoining portions of the Arcades, to the Commissioners of Works for a term of fifty years from 1891, at a rent of $£ 3,500$ a year. We subsequently increased this rent by the sum of $£ 154$, representing 4 per cent. interest on the cost of tiling the ground floors of the galleries and relaying the fire mains, which improvements we had undertaken at the instance of the Commissioners of Works in accordance with the terms of their lease. The rent we have received for these galleries 
is equivalent to interest at approximately 3 per cent. on the sum we have expended on them.

We recently made arrangements with His Majesty's Office of Demolition Works for the surrender to us of the north end of the Eastern Exhibition Galleries, intersecting the two adjoining sites granted by us to the Imperial College of Science and Technology. This portion of the Galleries has been demolished so that the Imperial College, as explained below in our account of that Institution, might possess a compact piece of ground with a frontage on Exhibition and Prince Consort Roads on which to erect the new section of their buildings which is to be devoted to mining and engineering. In consideration of this surrender the total rent of $£ 3,654$ a year, payable for the galleries by the Office of Works, has been reduced by the sum of $£ 720$, the abatement representing the approximate rental value of the surrendered portion, as based on the existing rent.

In our last Report we described the plan we had adopted for appropriating a part of the upper portion of our unoccupied estate on the north of the Imperial Institute for private building purposes. We explained that after provision had been made for the construction across the estate of a new road (Prince Consort Road) from Exhibition Road to Queen's Gate, there would be laid out a central space forming an approach from the new road to the south side of the Royal Albert Hall having on each side of it two large sites suitable for mansions, and that on the south side of the road there would be two further plots that would also serve as sites for private buildings, one on each side of the land which we had allotted to the Royal College of Music. We stated that we had already accepted a tender for a building lease of the two sites on the north of the new road at a rent of $£ 5,000$ a year, and that we had given the lessee the option of taking the two remaining sites on the south of the road at a rent of $£ 3,000$ a year, which he subsequently exercised.

The lessee proceeded to erect a block of flats on the plot on the east of the open space leading to the Royal Albert Hall, but the work had only been partially completed when the failure of the Liberator Building Society, which had undertaken to finance him, prevented the continuation of his contract. The building remained in its unfinished state for a considerable time, and as no measures were taken to continue the work, on which $£ 120,000$ had been expended, or to develop the remaining plots within the period provided for in the building agree-

The derelopment of the estate. end of Eastern Galleries. Private buildings.

Contract for their erection unfulfilled 
ment, we resumed possession in 1894. Meanwhile our new road, named after our illustrious first President, had been completed, and the Removal of statue of the Prince Consort had been removed from the position it statue of

Prince

Consort. formerly occupied in the centre of the Horticultural Gardens to its present position on the central space leading from Prince Consort Road to the Royal Albert Hall.

Albert

Court syndicate.

Our subsequent negotiations to re-let these building plots resulted in the execution of a building agreement with the Albert Court Syndicate, Limited, under which the Syndicate were to complete the halffinished building, and, subject to the fulfilment of the conditions specified in the agreement, were to be entitled to a lease of the site and building for ninety-nine years from 25th March, 1895, at a peppercorn rent for the first year, and at a rent of $£ 2,750$ for subsequent years, with the option of purchase. By virtue of their agreement, the Syndicate exercised in 1898 their option to purchase the freehold of the property for the sum of $£ 82,500$, being thirty years' purchase of the ground rent.

The other sites remained vacant and unoccupied, except for temporary purposes, until, as we explain elsewhere, they were appropriated, together with the site at the corner of Prince Consort and Exhibition Roads, for the purposes of the Imperial College of Science and Technology.

Laying out of central space completed.

Grant of site fol a church.

Prince Consort Road taken over by Westminster City Council.

In 1898 we completed the laying out of the central space, but the work for the construction of the new entrance to the Albert Hall, which had been delayed in consequence of the afore-mentioned failure of the contractors to fulfil their undertaking, was only partially completed in that year through want of funds on the part of the Corporation. The recent completion of this work has already been referred to in the account of our transactions with the Albert Hall.

In 1901 we conveyed to the Ecclesiastical Commissioners, for the sum of $£ 6,000$, a portion of the plot west of the central space, containing about 12,000 superficial square feet, as a site for a church, which we had decided to grant on the most favourable terms in consequence of representations made to us by the incumbents of the district parishes of All Saints' and Holy Trinity, Knightsbridge.

In 1907 the Westminster City Council took over the control of the Prince Consort Road, but as a condition precedent to the transfer we had to provide for the cost of paving it with wood. We are at present in negotiation with the Westminster City Council for taking over the remainder of our property in the roadways converging on the courtyard of the Royal Albert Hall, and we have included in our 
proposals to that body the transfer of the courtyard of the Royal Albert Hall.

In 1905 we agreed to grant a sum of $£ 1,000$ to the National Associa- National tion for the Promotion of Technical and Secondary Education, of which body the late Duke of Devonshire was President. The Association performed, during its rather brief career, a most useful function as a centre for information regarding the developments of technical and secondary education throughout the country, and also as advisers to various local authorities in the difficult and important work entrusted to them by Parliament.

Our attention was drawn in 1902 to an important proposal for making provision at South Kensington for a great Central College of Applied Science. His late Majesty King Edward was much interested in this proposal, and it was by his command that the late Duke of Devonshire, the Earl of Rosebery, and Mr. Balfour addressed to us a Memorandum in which it was formulated. After alluding to the inadequate provision in this country for the most advanced training and research in various branches of science, especially in their application to industry, and emphasising the desirability of establishing a College on the lines of the Royal Technical High School, Berlin, the Memorandum indicated certain sites on our estate as most suitable for the erection of buildings that would be required in connection with the proposed Institution.

In the same year a striking report had been presented to the Report of London County Council by its Technical Education Committee on the application of science to industry, in which it was clearly shown that several industries in this country had suffered, and were still suffering, L.C.C. Teclunical Education Committee. from the inadequate provision made for advanced instruction and research in scientific technology. The report stated that the Committee were "unable to resist the conclusion that various branches of industry have, during the past twenty or thirty years, been lost to this country owing to the competition of foreign countries; that in many others our manufacturers have fallen seriously behind their foreign rivals ; that London, in particular, has distinctly suffered; that these losses are to be attributed in no small degree to the superior scientific education provided in foreign countries."

In June of the following year there appeared in the press Lord Lord Rosebery's letter to the late Lord Monkswell, at that time Chairman Rosebery's of the London County Council, in which he alluded to the report Lord 
referred to, and outlined proposals for the institution in London of a centralised College which should provide the highest form of technical training, adding that he and certain other Trustees had received munificent offers of contributions towards the cost of building and equipment. As to the site, Lord Rosebery suggested that in view of the national importance of the scheme, we might be willing to place a site on our estate at the disposal of the trustees. Govern- Much public attention was directed to the proposal as a whole, enquiry by Departmental Committee. and in April, 1904, the Board of Education appointed a Departmental Committee to enquire into the working of the Royal College of Science, including the Royal School of Mines, and to consider in what manner the buildings and appliances then in occupation, or in course of construction, might be utilised to the fullest extent for the promotion of higher scientific studies.

During the progress of the deliberations of this Departmental Committee we were made acquainted with the main outlines of the scheme which the Committee proposed, and we allowed our opinion to be known that the appropriation of a portion of our unoccupied estate to the furtherance of such a scheme would be in accordance with the objects of our trust, provided that funds for the crection, equipment, and proper maintenance of the building were forthcoming.

Preliminary In a Preliminary Report, issued in February, 1905, the Departmental
Report. Committee, referring to the support that might be cxpected from private sources, stated "that the Commissioners of the 1851 Exhibition are prepared with their accustomed liberality where the advancement of higher education is concerned, to make available for a scheme, such as we have sketched, the additional site which will be required."

Final Report.

The Departmental Committee submitted its Final Report in January, 1906, and its main conclusions were as follows :-

" 1 . That the position of this country makes further provision for advanced technological education essential.

"2. That the students, by whose advanced technological education the nation would profit, are not actually obtaining it to the extent which is desirable, and that this is due to :-

"(a) The lack of facilities for instruction in certain important subjects ;

"(b) The absence of such co-ordination among existing institutions of technological education as would permit the concentra- 
tion of the more advanced courses in a limited number of institutions;

"(c) An insufficient appreciation, especially on the part of employer's, of the value of such education.

" 3 . That the opportunities for research in our technological institutions are inadequate to the industrial needs of the Empire, owing not to any want of ability on the part of the professors, but to the fact that much of their time is frequently absorbed in the giving of comparatively elementary instruction in Pure and Applied Science.

"4. That in any institution in which the highest technological education is given, the equipment should be adequate for the purpose, and the staff should include, at the head of the several specialised branches of the work, men of the first rank in their profession."

As a result of these conclusions they made recommendations which Summary they summarised thus :of recommendations.

"That the present combination of conditions at South Kensington points to the desirability of so utilising the resources there available, and of making additions to these, as to form on that site an institution of the highest standing, an institution which, with the staff, equipment and students that it will command, would go far towards remedying the above-mentioned defects."

The first section of this Report concluded with the following words :-

* There is a special fitness in closing this Section of our Report with some appreciation of the work of another body, the Commissioners of the Great Exhibition of 1851, who, by the manner in which they have executed their trust throughout the half century of their existence, have been intimately associated with, and in a large measure responsible for, the educational developments of South Kensington, and who are now crowning their services to higher scientific education by their willingness to place an extensive site on their estate at the disposal of a scheme designed to carry out the objects contemplated in our Recommendations, subject, of course, to their approval of the form which the scheme shall eventually assume. 'This body received power, by their Supplemental Charter, to apply the

Appreciation of the work of the 1851 Commissioners. 
surplus arising from the Great Exhibition to "purposes strictly in connection with the ends of the Exhibition." The Commissioners, acting, till his death, under the Presidency of His Royal Highness the late Prince Consort, to whom more than to any other individual was due the conception of the ends of the Exhibition, as well as its success, have from the first set before themselves, in pursuance of their charter, the advancement of higher education, particularly in the sciences applicable to industry. It is a gratification to us that the conclusions at which we have arrived, and the Recommendations which we are about to submit, are in close conformity with the aims and policy of the Commissioners as indicated in their periodical reports and their public action."

Royal

College of Sciencenew buildings.

Imperial CollegeCommissioners' approval of scheme.
Site of $3 \frac{1}{2}$ acres given.

The year which saw the publication of the Committee's Report was also notable for the opening of the new buildings of the Royal College of Science, which contain probably the most complete and best equipped laboratories for advanced study in Chemistry and Physics at present existent in this country. These buildings had been erected on a portion of the site of $4 \frac{1}{2}$ acres which we sold to the Government in 1890 and to which we have already alluded in the beginning of this
Report.

Steps were next taken to procure the grant of a Royal Charter for the incorporation of a new Institution on the lines which had been suggested, and we were given the opportunity of carefully considering the final details of the scheme before the Petition for the grant was presented to His late Majesty.

We came to the conclusion that an Institution or group of associated Colleges with the name of the Imperial College of Science and Technology under a single Governing Body, such as had been indicated, would be in a strong position to promote the organisation of advanced education and research in Science as applied to Industry, and we decided that its establishment was in complete accord with the original intention of the Commission as expressed in their Supplemental Charter, which declares "that no measures could be so strictly in accordance with the ends of the Exhibition as those which might increase the means of industrial education, and extend the influence of science and art upon productive industry." We accordingly resolved to place at the disposal of the Governing Body, as soon occupying about $3 \frac{1}{2}$ acres. 
His late Majesty was graciously pleased to grant to the Imperial Grant of College a Charter * of Incorporation on Sth July, 1907, and two Charter. members of our Commission (Viscount Esher, and Lieut.-Colonel the Right Hon. Sir Arthur Bigge) were appointed as members of the first Governing Body.

The Charter laid down that the purposes of the Imperial College "are to give the highest specialised instruction, and to provide the fullest equipment for the most advanced training and research in various branches of Science, especially in its application to Industry, and to do all or any of such other things as the Governing Body hereinafter constituted consider conducive or incidental thereto, having regard to the provision for those purposes which already exists elsewhere. And for these purposes the Governing Body, subject to the provisions of . . . the Charter, shall carry on the work of the Royal College of Science, and the Royal School of Mines, and may establish Colleges, or other Institutions, or Departments of instruction. And any Institution or Department so established and . . . the Central Technical College of the City and Guilds of London Institute shall be integral parts of the Imperial College ....'

Shortly after the establishment of the Imperial College we received an application from the Governing Body for a further site on our estate at South Kensington, which we had previously reserved for a sites. proposed Institute of Medical Sciences, but which, owing to the abandonment of the scheme, was no longer required for the purpose. This plot, which lies to the north of the City and Guilds College, at the corner of Prince Consort Road and Exhibition Road, and comprises nearly three-quarters of an acre, we resolved to add to our other appropriation of land for the purposes of the Imperial College.

In October, 1909, effect was given to these appropriations by Grant of the granting of a lease $\dagger$ of the four sites on our estate, abutting on 999 years' Prince Consort Road, to the Imperial College for the period of 999 years at a yearly rental of $£ 5$.

More recently we have added a further site, containing about a quarter of an acre, which was occupied by the north end of the Eastern Exhibition Galleries housing the India Collection of the

* A copy of Charter, together with subsequent Orders in Council allowing amendment of same, will be found in the Appendix (J, page 120).

† A Copy of the lease will be found in the Appendix (K, page 136).

Demolition of part of Eastern Galleries to allow extension of Engineering Department. 
Victoria and Albert Museum. This building intersected the sites allotted to the Imperial College and greatly impaired their value, and so, by arrangement with His Majesty's Office of Works and the Board of Education, this portion of the Galleries was demolished, in order that the Imperial College might be in possession of a compact piece of ground on which to build the proposed extension to their Engineering Department.

The result of these grants to the Governing Body of the Imperial College of Science and Technology is that a total area of approximately $4 \frac{1}{2}$ acres of our estate has been made available for the development of the College.

Foundation stone of new buildings laid by King Edward.

On 8th July, 1909, His late Majesty the King was graciously pleased to lay the foundation stone of the new buildings which are to be erected on the site, and are intended to afford accommodation for the departments of Mining, Metallurgy and Geology, and for an extension to the Engineering Department of the City and Guilds College. In the remarkable speech which His Majesty delivered on that occasion he gave expression to a sentiment with which we are so completely in accord that we cannot do better in concluding this paragraph of our Report than quote his very words :

His words.

"In recent years the supreme importance of higher scientific education has, I am happy to say, been fully recognised in England; and as time goes on I feel more and more convinced that the prosperity, even the very safety and existence, of our country depend on the quality of the scientific and technical training of those who are to guide and control our industries."

Science Nuseumproposed establish. ment of permanent building.
In July, 1909, the question of providing a permanent building at South Kensington for the accommodation of the national Science Collections was brought to the notice of H.M. Government by an influential deputation which waited upon the President of the Board of Education with a memorial * signed by many eminent men directly interested in Science and its application to industry.

The object of the deputation was to call attention to the crowded

* A Copy of the Memorial is givon in the Appendix (L, page 138). 
and unsatisfactory condition of the science collections at South Kensington, and to ask that these collections should have room for rearrangement and expansion, and that such a museum which represented the application of science to material should be placed by the Government in the same position as art and natural history.

In the early part of last year H.M. Government showed that they fully recognised the importance of the subject by appointing a Committee to prepare a scheme for the re-organisation and proper housing of the collections which are mainly contained in temporary buildings at South Kensington.

We welcomed this practical step on the part of the Government towards satisfying a national want, especially as we had long regarded the establishment of such a museum as an essential complement to the group of buildings already erected on our estate.

Our association with the Museums at South Kensington is of long standing, and has not been confined to the provision of sites. We presented to the nation the collection of animal products which formed an important feature of the South Kensington Museum when it was first established on our estate in 1857, and we also assisted at that time in the provision of the Museum building. The Royal Commission on Scientific Instruction and the Advancement of Science in their Fourth Report, 1874, recommended the establishment of a National Museum of Collections illustrating Science and Invention. Our desire to see this proposal realised led us to offer in 1876 a site, and funds to the extent of $£ 100,000$, for the erection of a permanent building. Although our offer, which was again repeated in 1878, was subsequently declined by the Government, we considered that the establishment of such an institution could only be a question of time, and we therefore continued to reserve a site for the purpose.

But the pressure of a somewhat heavy mortgage debt and the encroachment made on our resources in favour of other public institutions induced us in 1890 to sell to the Government, for considerably less than its value, the site we had so long reserved for the new museum. We have already described this transaction in the earlier part of this Report.

The public attention directed to the new scheme and the strong evidence submitted in support of the proposals for a new museum by those who are best qualified to judge of the present needs of scientific education, convinced us that H.M. Government could not fail to appreciate the urgency of the matter. But realising that a 
Offer repeated this year.

List of institutions on the property. considerable sum of money would be required to complete the scheme, we caused H.M. Government to be informed that we were prepared to assist them in providing for the cost of the museum by a grant from our investments of $£ 100,000$, provided we were satisfied that sufficient funds were forthcoming to ensure the erection of a suitable building at South Kensington. The Government have recently expressed their pleasure in accepting our ofier, but are not yet in a position to communicate to us the details of the scheme, which is still under the consideration of a Committee of the Board of Education.

We affix to this Report a plan (at end of volume) of the freeholds acquired by us in the years 1852 and 1853, and also a plan (facing title page) showing the present state of the development of the property.

Of the 87 acres originally purchased with the proceeds of the Great Exhibition of 1851, about 18 have been absorbed by roadways in the course of developing the estate, 17 have been appropriated for private residential purposes, and the remaining 52 have been devoted to public purposes.

The following list of institutions now situated on the property will show how the main portion of the estate has been appropriated:

1. The Victoria and Albert Museum.

2. The Royal College of Art.

3. The Natural History Museum.

4. The Science Museum.

5. The India Museum.

6. The Royal Albert Hall.

7. The Royal College of Music.

8. The Royal College of Organists.

9. The Alexandra House.

10. The Royal School of Art Needlework.

11. The Meteorological Office.

12. The Imperial Institute, including headquarters of the University of London.

13. The Imperial College of Science and Technology, including (1) the Royal College of Science; (2) the Royal School of Mines; (3) the City and Guilds College.

Finance and Accounts.

In continuation of the financial statement appended to our Seventh Report, we now submit (see Appendix M, page 146), a duly audited 
Statement of our Receipts and Payments from 1st January, 1889, to 31st December, 1910, together with a statement of our Assets and Liabilities at the conclusion of that period (see Appendix N, page 148).

At the date of our last Report our mortgage debt amounted to $£ 134,325$. With the money realised by the sale of a portion of our estate to the Government in 1890, and by the sale of ground rents on the residential part of our estate, we succeeded in paying off the whole of this debt in the year 1893, when the cstate was declared to be absolutely free from all charges for the first time since our dissolution of partnership with the Government in 1858.

During the period covered by this Report, we have expended nearly $£ 44,000$ on improvements to the estate and buildings, structural alterations, road making, etc. We have advanced on loan to the Royal School of Art Needlework the sum of $£ 20,000$, and we have afforded financial support to the Royal Albert Hall to the extent of $£ 32,000$.

After the extinction of the mortgage debt we invested our Increase of surplus income and the moneys realised by the sale of ground rents, with the result that in recent years our revenue has considerably increased, and we are thus enabled to give greater effect to the furtherance of the objects for which we were incorporated.

We showed in our last report that we had contributed to public Contribupurposes money and property amounting to over $£ 800,000$.

Since that time about $4 \frac{1}{2}$ acres of land, valued at $£ 200,000$, have tions to public purposes. been allotted to the Imperial College of Science and Technology; $£ 105,000$ has been provided for the creation and maintenance of our system of Scholarships and Bursaries; the sum of $£ 18,520$ has been contributed towards the upkecp of the Research Laboratory attached to the Imperial Institute, and subscriptions to the Royal College of Music, amounting to $£ 11,000$, have been devoted to musical education.

By the sale to the Government in 1890 of the $4 \frac{1}{2}$ acres of land south of the Imperial Institute Road, at less than half its value, we presented to the nation a gift of more than $\mathcal{1} 100,000$. We have leased to the Royal School of Art Needlework a site worth at least $£ 18,000$ at a rent equal to about one-third of its annual value, and we have leased at a nominal rent to the Royal College of Organists the valuable site and house formerly occupied by the Royal College of Music. Thus our contributions to public purposes up to the present time approach the considerable sum of $£ 1,250,000$. 
Considera-

tion of

Future

Policy.
One of the objects which the Commissioners had in view in purchasing the Kensington Gore Estate with the surplus funds of the Great Exhibition, was to form a centre for such institutions as were engaged in the promotion of Science and Art, and more especially in their application to industry. The list of institutions, to which has been assigned the greater portion of the original estate, will show that this object has been successfully carried out.

When we became free from the encumbrance of a heavy mortgage debt we were enabled to devote a considerable portion of our income to Scholarships for Scientific Research. The remainder has been invested from time to time, so that we are now in a position to increase the scope of our activities.

We have accordingly considered the uses to which we should apply our funds in the immediate future. It is not contemplated to disturb the existing provision of Scholarships for purposes of research ; but in our opinion a point has been reached when the capital resources of the Commission should no longer be applied to assist in the erection of buildings at South Kensington, and when the balance of the income derived from our present funds should be so used as to give a further impetus to scientific and artistic training consistent with the objects of our Charter. We believe that our income can be used to great advantage by the provision of Scholarships and Bursaries endowed not for all time, but for limited periods, and directed specially to encourage not only research work, but also the training of "Captains of Industry." We shall, moreover, endeavour to include in any extension that we may hereafter devise for our scheme of Scholarships some provision for encouraging the study of the Fine Arts on lines corresponding to those which have proved so efficacious in relation to Science and its applications. In such assistance as we may afford from time to time to the solution of problems affecting the industrial welfare of the nation, we shall have regard principally to schemes which from their nature require support from other than ordinary sources.

We shall, therefore, make it our duty to apply such sums as we think fit to the promotion of these objects, while avoiding as far as possible any further diminution of the corpus of our estates and invested funds, or any permanent alienation of our income.

Conclusion. We camnot conclude this Report without recalling that it is to the far-seeing wisdom of our Tirst President, His Royal Highness the Prince Consort, by whose advice the surplus funds of the Great Exhibition were invested in the purchase of the Kensington Gore Estate, that 
we owe in large measure our present position with its possibilities of increasing usefulness; and we feel confident that our future policy carried out on the lines we have suggested, will prove in its results not unworthy of those great ends which His Royal Highness had in view.

It only remains for us humbly to express the hope that we may merit from His Majesty the same confidence as has ever in the past been reposed in us by the Sovereign, and to pray that His Majesty may deign to vouchsafe to us, as King, that gracious interest which, as our President, he always showed in our endeavours to advance the cause of Science and Art for the promotion of which we were incorporated.

Given under our Corporate Seal at St. James's Palace, this thirteenth day of March, 1911.

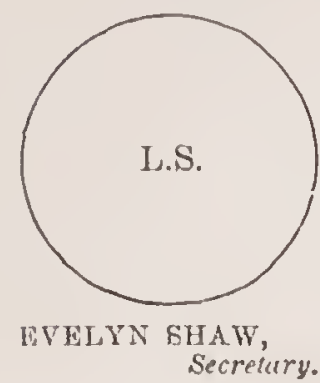

ARTHUR FREDERTCK.

ARTHUR.

CHIRISTIAN.

NORFOLK.

ARGYLL.

LANSDOWNE.

ROSEJERY.

BEAUCHAMP.

SPENCER.

ESHER.

MORLEY OF BLACKBURN.

RAYIEIGH.

IVELBY.

JAMES OF IIEREFORD.

COURTNEY OF PENIVITH.

H. H. A.SQUI'TH.
D. ILOYD GEORGE. SYDNEY BUX'TON. FRANCIS MOWATI. G. H. MURRAY. HENRY E. ROSCOF. I). M. PROBYN. ARTHUR BIGGL: ARCH. GEIKIE. CHARLES L. RYAN. NORMAN LOCKYER. ROBERI T. MORANT. F. G. OGILVIE. WM. GARNETT. ALEX. SIEMTNS. W. W. WA'T'L'S. 

APPENDICES. 


\title{
APPENDIX A.
}

(See Report, page 6.)

\section{List of the Royal Commissioners for the Exhibition of 1851 from the Formation of the Commission to the Present time.}

\author{
Presidents of the Royal Commisston.
}

His Royal Highness the Prince Consort. Appointed 3rd January, 1850. Died 14th December. 1861 .

Suceceded by

The Right Honourable Edward Geofirey, 14th Earl of Derby. Appointed Nember of the Commission 3rd January, 1850. Eileeted President 16th April, 1864. Died 1869.

Sueceeded by

His Royal Highness the Prince of Wales. Eleeted Member of the Commission and President 18th February, 1870. Came to the Throne 22nd January, 1901. Died 6th May, 1910.

Suceceded by

His Royal Highness the Prince of Wales. Elected Nember of the Commission 15th June, 1896. Elected President 10th February, 1903. Came to the Throne 6th IIay, 1910.

Succeeded by

His Royal Highness Prince Arthur of Connaught. Eleeted Nember of the Commission and President 13th Mareh, 1911.

Members of the Royal Commission.

Elected 16 Feb. $1872 *$ His Royal Highness the Duke of Edinburgh.

16 Fob. 1872 His Royal Highness Prince Arthur (Duke of Connaught).
" $\quad 21$ Oct. 1872 *His Royal Highness the Duke of Cambridge.

" $\quad 18$ Feb. 1870 His Royal Highness the Prinee Christian [Acting Chairman of General Purposes Commillee 7th February, 1871, to 16th June, 1871. Chairman of Board of Management 1881 to 1904].

"18 July $1870 *$ His Serene Highness the Duke of 'l'eck.

Appointed by Royal Commission-

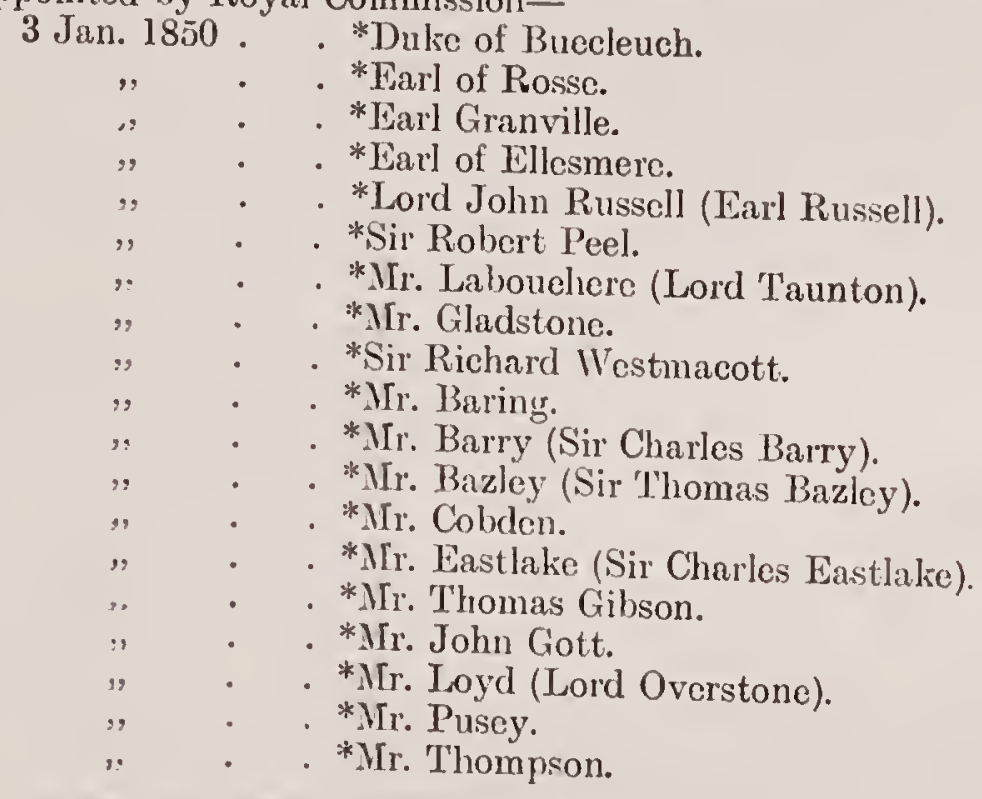

* Deceased. 
Appointed by Royal Cliarter-

15 Aug. $1850 *$ Mr. Robert Stephenson.

Eleeted 5 Mrar. 1851 *Sir Charles Lyell.

"14 Jan. 1852 *Sir William Cubitt.

" 24 April $1852 *$ * ${ }^{2}$. Dille (Sir Charles Wentworth Dilke).

" 24 April $1852 *$ Mr. John Shepherd.

"24 April $1852 *$ Nr. Alexandcr Spearman.

" 29 June 1852 *Mr. Walter Coulson.

" 25 Jan. 1853 *Mr. Disraeli (Earl of Beaconsfield).

" 30 Juuc 1855 *Sir Roderick Murchison.

" 14.Feb. 1857 *Lord Portman (Viscount Portman).

" 1 May 1858 *Sir George Cornewall Lewis.

" 3 May 1861 *Marquis of Chandos (Duke of Buckingham)

" 3 May 1861 * Mr. Larbairn (Sir Thomas Fairbairn).

3 May 1861 * Mr. Thring (Lord 'l'hring).

30 June $1863 *$ Mr. Lowe (Viscount Sherbrooke).

30 June $1863 *$ Sir Stafiord Northcote (Earl of Iddesleigh).

30 Junc $1863 *$ Sir Morton Peto.

30 July $1866 *$ Mr. Bruce (Lord Aberdare).

30 July 1860 *Sir Liancis Giant.

8 July 1869 Mr. Bowring [formerly T'reasurer and Member of Finance and General Purposes Commillees].

8 Jily 1869 *Gencral the Hon. Charles Grey.

8 July 1869 *Sir Francis Sandford (Lord Sandford).

8 July 1869 *Dr. Lyon Playfair (Lord Playfinir).

$18 \mathrm{Feb} .1870$ *Edward Henry, 15th Larl of Derby.

12 May 1870 * Major-General Sir Thomas Biddulph.

12 May 1870 *Colonel Ponsonby (Sir Henry Ponsonby).

$18 \mathrm{July} 1870$ * Earl de Grey and Pipon (Marquis of Ripon).

18 July 1870 *Sir William 'Iite.

, 18 July 1870 * Mrr. Beresford Hope.

, 13 Aug. 1872 *Sir William Anderson.

, 13 Aug. 1872 * JIr. Cole (Sir Henry Cole).

, 21 Oct. 1872 Marquis of Lansdowne [fomerly Member of General Purposes Cum millee and Board of Management].

22 lich. 1873 * Earl of Carnarvon.

22 Feb. $1873 *$ Mr. Childers.

22 Feb. 1873 *Sir Anthony de Rothsehild.

22 lieb. 1873 * Sir Richard Wallace.

22 Feb. 1873 *Sir Henry Bartle Frere.

8 Dee. 1873 *General Sir Williarn Knollys.

8 Dee. 1873 Major-Gencral Probyn (Sir Dighton Probyn) [Treasurer].

25 Mar. 1874 *Earl Spencer.

9 May 1874 Earl of Rosebery [formerly Member of Board of Management].

24 May 1876 * Marrquis of Salisbury.

20 July $1877 *$ Admiral Sir Alexander Milne.

20 July 1877 †Colonel Ellis (Sir Arthur Ellis).

- 29 July $1878 *$ Dute of Sutherland.

, 26 July 1879 * Earl of Dudley.

26 July $1879 *$ Sir Frederick Leighton (Lord Leighton).

, 12 July 1881 *Lord Selborne (Larl of Selborne).

, 12 July 1881 *Sir Sydney Waterlow.

, 12 July 1881 *Mr. Bramwell (Sir Frederick Bramwell).

, 25 July $1883 *$ Nr. Mindella.

", 12 Mar. 1887 *Lord Hersehell.

" 16 Mlay 1889 *.Mr. Fowler (Sir Henry Fowler and Viseount Wolverhampton) [late Chairman of Board of Management].

, 27 July 1891 Duke of Fife.

, 27 July 1891 * Baron Ferdinand de Rothschild.

, 27 July 1891 *Sir William 'Thomson (Lord Kelvin).

,. 27 July 1891 Sir Henry Roscoe [Member of Board of Management and Chairman of Scholarships Commillee].

, $\quad 27$ July 1891 *Professor Huxley.

" 27 July 1891 Marquis of Lornc (Duke of Argyll).

", 27 July 1891 Professor Lockyer (Sir Norman Lockyer) [Member of Scholarships Commitlee].

, 15 June 1896 Lord Welby.

* Deceasel.

$\dagger$ Resigned in 1889 on being appointed Secretary of the Royal Commission; died 1907. 


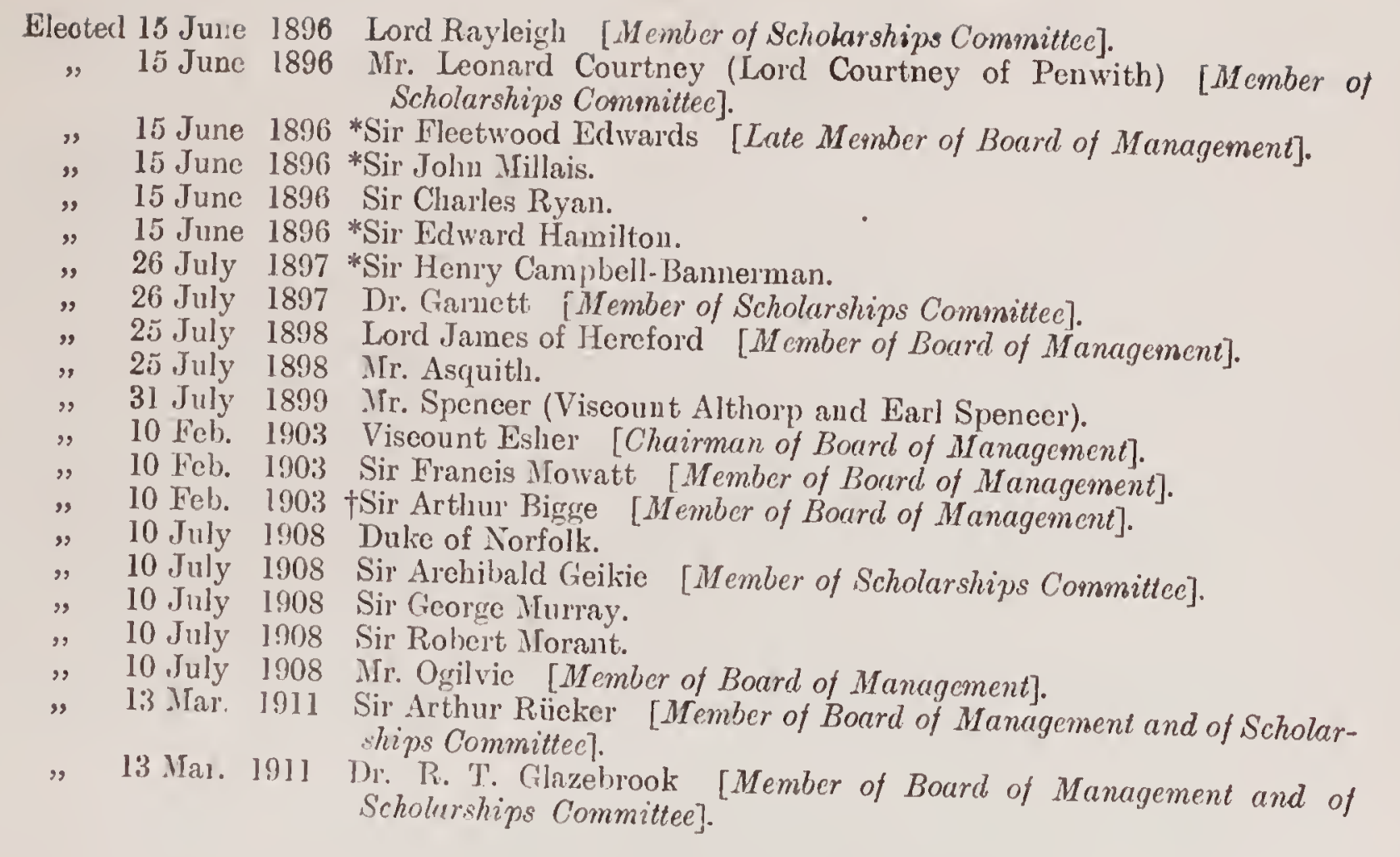

Appointed by Royal Commission3 Jan. 1850 . Chairman of the Court of Direetors of the East India Company.
Ceased 1858.

$\because \quad$. President of the Geological Society. (Professor W. W. Watts)

Elected 23 Feb. 1853 Lord President of the Comeil. (Viscount Morley Alexanler Siemens)

$" \quad 23$ Feb. 1853 Finst Lord of the Treasury. (Mr. Asquith)
$" \quad 23$ Feb. 1853 Chaneellor of the Exehequer. (Mr. Borley of Blackburn)

$" 23$ Feb. 1853 President of the Board of Trade (Mr. Lloyd George)

"2 23 Feb. 1853 First Commissioner of Worles. (Mr. Sydney Buxton)

$" \quad 14$ Feb. 1857 Vice-President of of Works. (Farl Beauchamp) 1899.

\section{APPENDIX B.}

(See Report, page 9.)

\section{Deed of Conveyance to H.M. Government of the Site South of the Imperial Institute Road.}

This Ividexure, made the 31st day of March 1890, between the Commissioners for the Exhibition of 1851, incorporated by and for the purpose of two several Royal Letters Patent under the Great Seal dated respectively the 15th day of August 1850 of the one part, and the Commissioners of called "the Exhibition Commissioners"), acting in execution of the Act 15th and 16ther Majesty's Works and Public Buildings, after called " the Commission Commissioners are seised for an estate in $f^{\text {f }}$, of the other part: Whereas the Exhibition and hereditaments hereinafter described simple in possession of the lands, buildings

* Deccrsed.

1911, after resigning Secretaryship. 
the lands, buildings and hereditaments eoloured pink on the plan drawn hereon) free from ineumbrances: AND wHEREAs the Commissioners of Works are seised for an estate in fee simple in possession of the lands and hereditaments situate on the east side of the road known as Queen's Gate (being the lands eoloured blue on the said plan drawn hereon), whieh said lands and hereditaments were, with other lands and hereditaments, conveyed to the Commissioners of Works by the Exhibition Commissioners by an Indenture dated the 14th day of September 1864, subject to a stipulation that the said lands and hereditaments thereby eonveyed shonld be permanently used for purposes eonneeted with scienee or the arts: AND WHEREAs the Commissioners of Works have, with the consent of the Lords Commissioners of Her Majesty's Treasury, agreed with the Exhibition Commissioners for the purchase, out of moneys voted by Parliament for that purpose, of the said lands, buildings and hereditaments eoloured pink on the said plan at or for the priee of $£ 100,000$, and on the treaty for sueh purehase it was stipulated by the Exhibition Commissioners that the said lands, buildings and hereditaments so to be purehased should be permanently used for purposes eonneeted with seienee or the arts, and it was stipulated on the part of the Commissioners of Works that so much of the lands and hereditaments comprised in the said Indenture of the 14th day of September 1864, as is eolomred blue on the said plan hereinbefore referred to, should be released from the stipulation that the same should be permanently used for those purposes to which the Exhibition Commissioners assented on the Commissioners of Works agreeing to enter into the eovenants hereinafter eontained restrieting the user of the last-mentioned lands and hereditaments to sueh extent as hereinafter appears: Now this Indexture witxessetil that for effeetuating this said Agreement and in consideration of the sum of $£ 100,000$ paid by the Commissioners of Works to the Exhibition Commissioners at or immediately before the exeeution of these presents, the reeeipt of whieh said sum of $£ 100,000$ the Exhibition Commissioner's do hereby aeknowledge, the Exhibition Commissioners, as benefieial owners, do hereby grant and eonvey unto the Commissioners of Works, their sueecssors and assigns, Alu that piece or pareel of land, situate in the parishes of St. Margaret, Westminster, and St. Mary Abbott, Kensington, respeetively, in the eounty of Middlesex, bounded on the north by a new road called or intended to be called the Imperial Institute Road, on the east in part by Exhibition Road and in part by land eonveyed to the Commissioners of Works by the said Indenture of the 14th day of September 1864, on the south by land comprised in the said Indenture of the 14th day of September 1864, and on the west in part by land eomprised in the said Indenture of the 14th day of September 1864 and in part by other land the property of the Exhibition Commissioners, as the same with the dimensions and abuttals thereof is delineated on the said plan drawn on these presents and thereon eoloured pink: Together with all the ereetions and buildings situate on the said land and belonging to the Exhibition Commissioners and together with the appurtenances: To have and to hold the said premises unto and to the use of the Commissioners of Works, their sueeessors and assigns, for ever, to be by them held for the public serviee aecording to the provisions of the said Act of the 15th and 16th years of Her Majesty, Chapter 28: Provided always Nevertheless, and it is hereby agreed and deciared, that the said lands and hereditaments, hereby conveyed, shall be permanently used for a purpose or purposes eonneeted with seienee or the arts, but this agreement shall not be decmed to oblige the Commissioners of Works, their suecessors and assigns, to retain the said buildings now standing on the said land: ANI THIS INDENTURE 
FURTHER WITNESSETH, that for further effcetuating the said Agreement, the Exhibition Commissioncrs do hereby release so mueh of the said land comprised in the said Indenturc of the 14th day of September 1864, as is coloured blue on the said plan drawn hereon, from theoperation of a stipulation, that the same shall be permanently used for a purposc or purposes connected with science or the arts. And it is hereby agreed and dcclared, that the Commissioners of Works do hereby covenant and agree with the Exhibition Commissioners that they, their sueessors or assigns, will not at any time hcreafter ereet or canse or suffer to be ereeted on the said land, coloured blue on the said plan, any messuage, buildings or other ereetions of any sort or kind to be used for, nor will usc or permit the said land to be used for the purpose of trade or business, and will not do or cause to be done on the same land any act, matter, or thing whieh may be or become a source of annoyanee, damagc, or inconvenience to the estate of the Exhibition Commissioners or to any of their tenants. And the Exhibition Commissioners hereby acknowledgc the right of the Commissioners of Works to the production of the documents of title mentioned in the Sehedule, subjoined or annexed to these presents, and to delivery of copies thereof, and hereby undertake for the safc custody thereof. Ix witxess, \&c.

\section{APPENDIX C.}

(See Report, page 11.)

\section{General Regutations for Science Research Scholarships.}

1. The Seholarships are intended, not to faeilitate attendancc on ordinary collegiate studies, but to enable Students who have passed through a College eurrieulum and have given distinct evidence of capacity for original research, to continue the proseeution of Science with the view of aiding its advance, or its application to the industries of the country.

2. The Seholarships are of $£ 150$ a ycar, and are ordinarily tenable for two years, the continuation for the sccond ycar being dependent on the work donc in the first year being satisfaetory to the Scholarships Committee.

3. A limited number of the Seholarships are ronewed for a third year where it appears that the renewal is likely to result in work of seientific importanec.

4. Candidates are recommended by the governing bodies of the Universitics and Colleges to which Scholarships arc allotted, and the recommendations arc considered and decided upon by the Seholarships Committee.

5. The candidate must be a British subjeet.

6. The Candidate must have been a bona fide student of Scienec in a University or College in which special attention is given to scicntifie study for a term of three years. 
7. The Candidate shall be eligible for a Scholarship provided (1) that he has spent the last full academic year immediately prior to the time of nomination as a student in any faculty or scientific department of that Institution by which he is nominated, or (2) that he has been a student of such Institution for a full academic year ending within twelve months prior to the time of nomination, and since ceasing to be such student has been engaged solely in scientific stndy.

The word "student" in the preceding regulation must be understood as comprehending one engaged in undergraduate or post graduate work.

8. The Candidate must indicate high promise of capacity for advancing Science or its applications by original research. Evidence of this capacity is strictly required, this being the main qualification for a Scholarship. The most suitable evidence is a satisfactory account of a research already performed, and the Commissioners will decline to confirm the nomination of a Candidate unless such an account is furnished, or there is other equally distinct evidence that he possesses the required qualification.

9. A Candidate whose age exceeds 30 will only be accepted under very special circumstances.

10. A Scholarship may be leeld at any University in England or abroad, or in some other institution to be approved of by the Commissioners. Every Scholar is, in the absence of special circumstances, required to proceed to an institution other than that by which he is nominated.

11. The principal work of a Scholar must be a research in some branch of Science, the extension of which is important to the national industries.

12. Scholars are required to devote themselves wholly to the objects of the Scholarships, and are forbidden to lold any position of emolument.

13. Scholars are required to furnish reports of their work at the end of each year of the tenure of their Scholarships. At the expiration of each Scholarship the reports of the Scholar are referred to an eminent anthority on the subject treated of, who furnishes an opinion thereon to the Commissioners.

14. The Scholarship stipend is payable half-yearly in advance, but $£ 25$ is reserved from the fourth payment until the Scholar has made a satisfactory final report.

\section{Regulations for Probationary Bursaries.}

1. A Bursary is intended for the maintenance for one year of a Student who proposes to become a Science Researcli Scholar under the scheme of the Commissioners at the expiration of the period covered by the Bursary, in order to afford him an opportunity of proving lis power to carry on independent researcl.. The authorities of an institution recommending a Student for a Bursary will be presumed to have satisfied themselves that he bonci fide intends to accept a Scholarship if subsequently appointed to one.

2. An applicant for a Bursary must, except as to evidence of capacity for original research, fulfil all the conditions for the time being laid down for appointment to a Science Research Scholarship. He must have passed a B.Sc. Examination (or its equivalent) with Honours before the commencement of the period covered by the Bursary. His age must not exceed 25, except under very special cireumstances. 
3. A Bursary is tenable for one year, and is of the value of $£ 70$, payable by half. yearly instalments in advance, the second instalment being payable on the receipt of a certificate from the Professor, under whom the holder has been working, that he has faithfully performed his duties.

4. A Bursary will be awarded on condition that the nominating institution undertakes to provide for the holder facilities for conducting research, and the requisite supervision, free from charge and incidental expenses.

5. The holder of a Bursiry shall devote himself exclusively to research, and work preparatory to research, and none of his time shall be spent in assisting a teacher in his duties. The holder of a Bursary must not hold any other Bursary, Scholarship, or position of emolument.

6. The holder of a Bursary shall on or before 1st May in the year of tenure send to the office of the Commissioners an account of the research work performed by him, together with an application for appointment to a Science Research Scholarship. The Commissioners will expect to receive from the Professor, under whom the holder of the Bursary shall have worked, a confidential opinion as to his capacity and qualifications.

7. The Commissioners may either appoint the holder of a Bursary to a Science Research Scholarship, or at their absolute discretion decline to appoint him, and in the latter case shall not be called upon to state any ground for their decision.

8. A Science Research Scholarship, if granted, shall be held on the usual conditions attached to the Scholarships, or on any special conditions wlich the Commissioners may impose. But a Scholar who previously to appointment has held a Bursary shall not be eligible for exceptional renewal of his Scholarship for a third year. 


\section{APPENDIX C. (continued). \\ (See Theport, page 11.)}

\section{LIST OF INSTITUTIONS INIITED TO RECOMMEND CANDIDATES FOR SCIENCL RESEARCH SCHOLARSHIPS.}

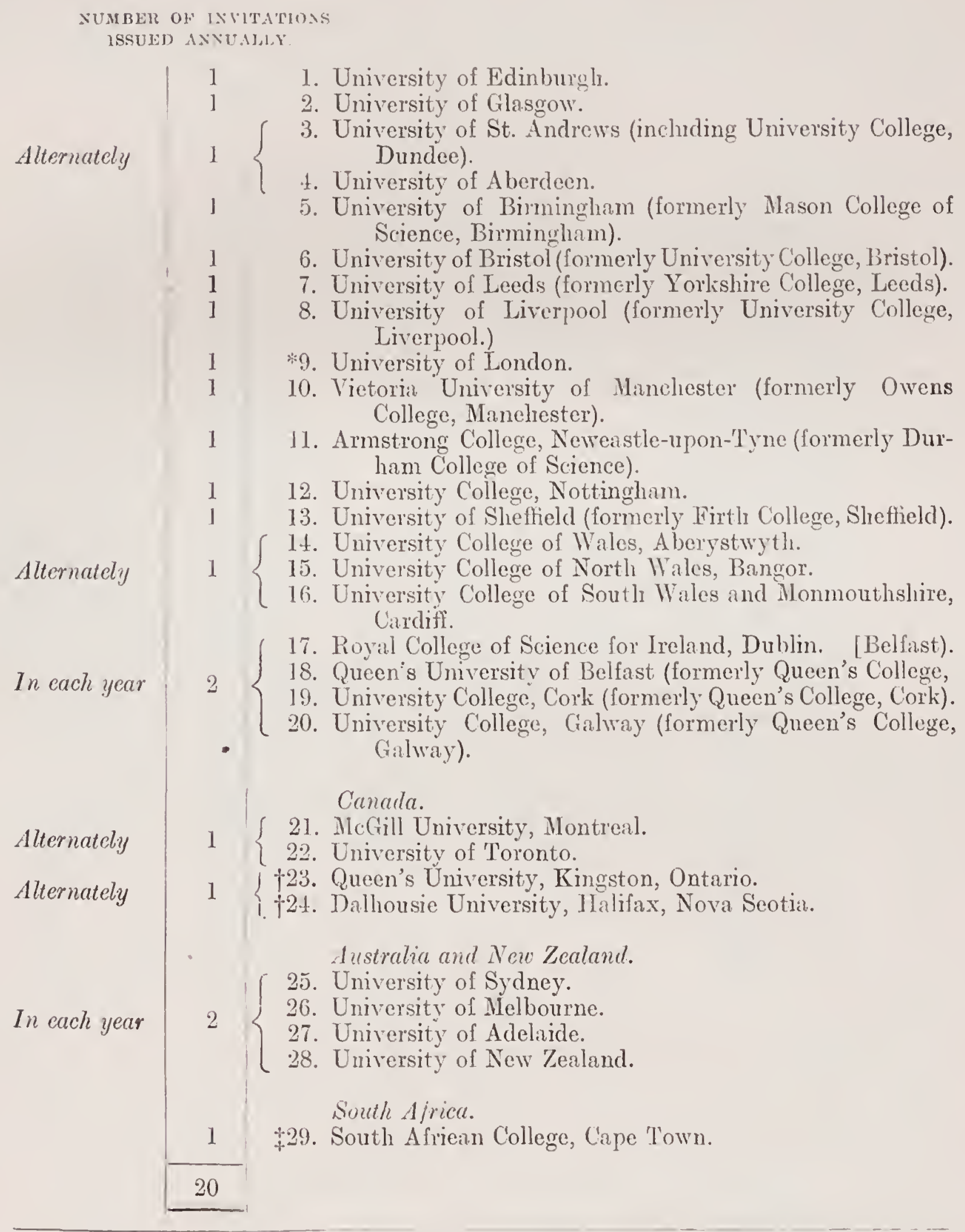

* University College, Iondon, was inchaded in the seheme of scholarships in 1892, but on its incorporation with the University of London, in 1907 , the nomination was placed at the disposal of the latter body.

t Inehded in the scheme in 1892 .

Included in the scheme in 1903 


\section{APPENDIX D.}

(See Report, page 12.)

\section{LIST OF SCIENCE RESEARCH SCHOLARS APPOINTED BETWEEN THE YEARS 1891 AND 1910}

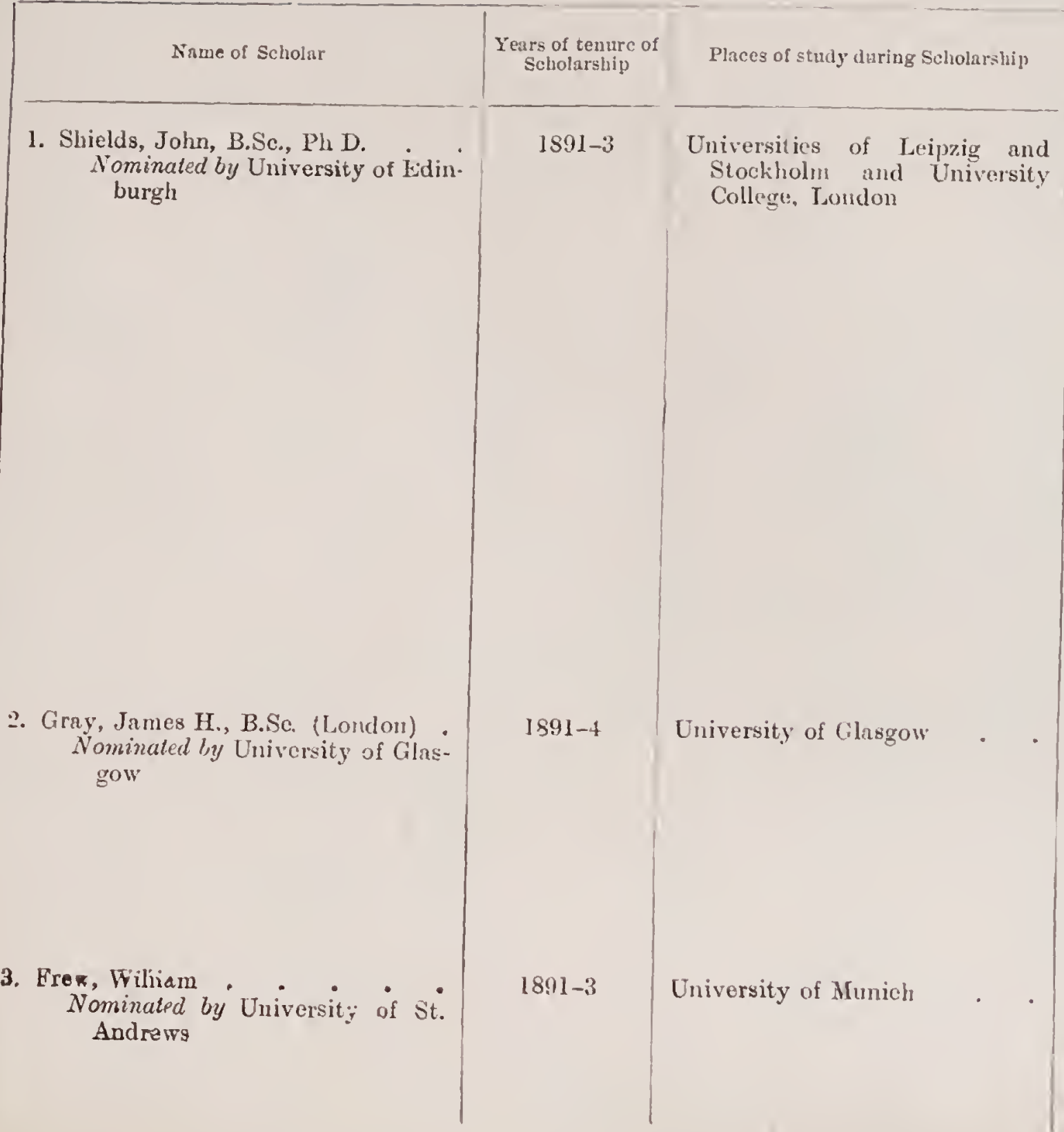

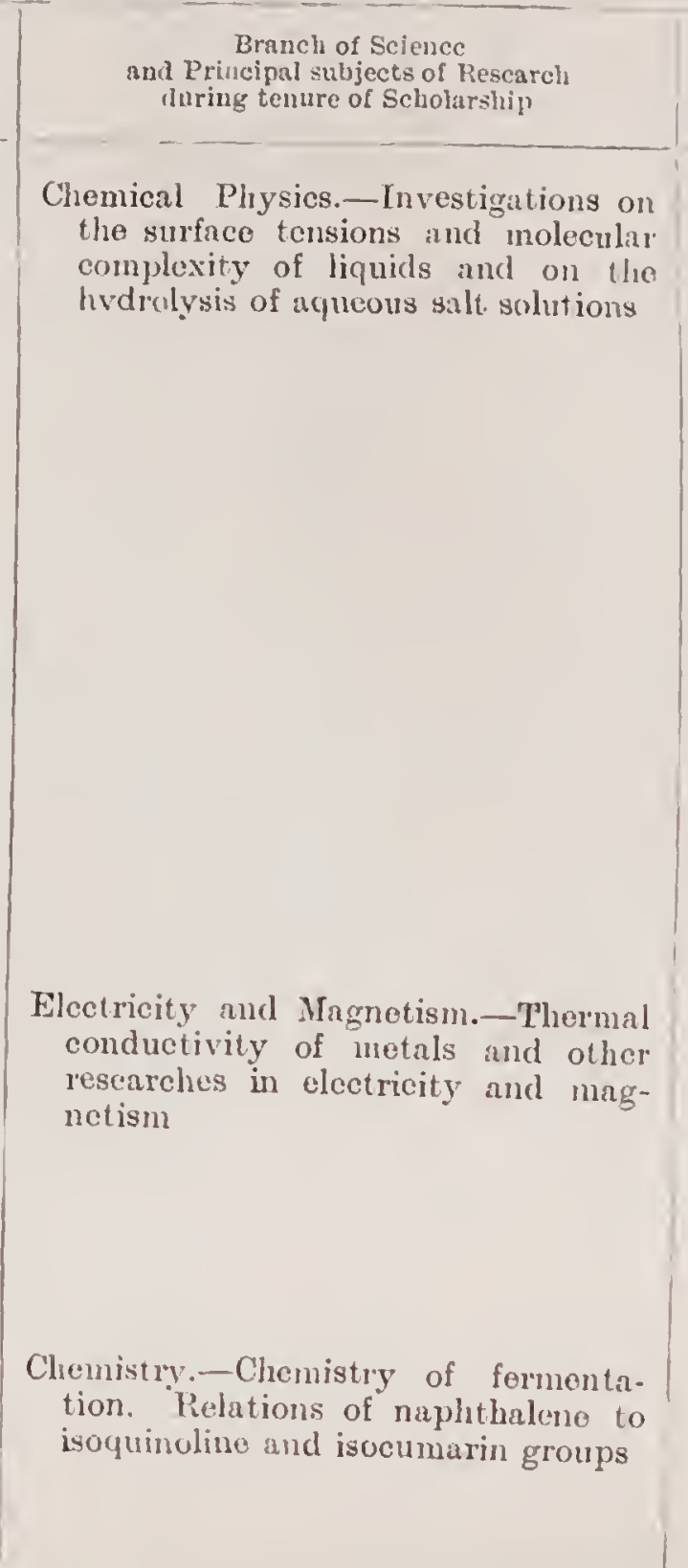

Degrees and other dis-
tinctions obtainat
since appointment to
Scholarship

D.Sc. Edin burgh

M.A. Glasgow

Ph.D. Munich (1893) Particulars of Scholar's subsequent carecr
as far as ascertibined

1893-8, private Assistant to Dr. in University College, London, in Davy- araday Research Laboratory, and in Dr. Monds private laboratories; also for a sliort time Assistant Manager in the Brunner-Nond Alkali Worke. 1899-1901, Resident.sciemtifiendidechical Adrise to the rcottish Cyanide Co., Lutd. Loven, Fife. 1901-3, again acted as Assistam. to Dr. Mond. Smeo 1903 Chief Chemicnl and Metallurgical Engincer to the liso Tinto Co., Ltd., in Iondon and Spain. Has been Examiner in Clemistry to the University of Aberdeen and the Institution of Civil Engincers, also Assistant Examinier in Chemistry to the Science and Art Department. Delivered the lectures on Phyrien Chemistry for one year at the Royal Collecre of Scicnce.

1895, called to the Bar, and practises chicfly in patent cases involving seientilic knowledge. 1906-9, Ascciate Menrber of Council, Institution of Electrical Encrinecrs March 1908, leading Counsel for the Hone Office on the inquiry held to consider proposed electrical rules (since issued) under the Factory Acts.

Deceased July 1910. 1893-4, worked at Munich in the Versuchstation fü Braucrei, the Gabelsbererbrauciei and the Thomasbrancrei $1894-1003$ Scientific Adviser to Messre. Tennent, Wellpark Browery; Glasgow. 
4. Sudborough, John Joseph

Nominated by Mason Seience College, Birmingham (now University of Birıningham)

5. Ewan, Thomas, B.Sc., Ph.D. (Munich) Nominated by Owens Collerge. Vanghester (now Victorin U versity of Hanchester)

Barton, Edwin H., B.So

Vominated by University College, Nottingham

7. Fawectt, Frederick Berijamin Nominated by University College. Bristol (now University Bristol)

8. MeConnell, William, A.Se Nominuted by Durham College of Seiense (now Armstrong College, Neweastle-upon-'Tyne)

9. Ingle, Harry, B.Sc. Nominated by Yorkshire College, Leeds (now University of Leeds)
$1891-1$

University of Heidelberg .

Chemistry. - Stereoisomerie stilbene
derivatives. Diortho - substituted
benzoie aeids. Esterfication of organic acids

$1891-1$

Owens College and University of Austerdaun

$1891-3$

Royal College of Sieience. London, and University of Bonn

1891-3

University College, Bristol

1891-3

Durham College of Scienco

$1891-4$ tra of various solutions and other researehes in physical chenistry

Electricity and Magnetism,-T'mperature variation of magnetic permeability of magnetite. Electrical interference phenomena, \&c.

Electricity and Magnetism.-Propagation of manotism through iron. Investigation of the olectieat inst ance of thin metallie films with id viow to the construction of standard resistances of high value

hysies.-Investigation of the gases enclosed in coal and coal-dust

University of Munich . . Chemistry.-Researehes on chemistry of flames and on para-acetylacetophenon and para-diaethylenbenzol and on some derivatives of tetrazol
Ph.D. Heidelberg (1893)

D.Se. London (1895)

M.Sc. Vietoria (1896)

1905 , Scientific Ad viser to Whiteway Co., Cider Makers, Whimple, Devon. 1906-1910, Scientific Adviser Makers, Hereford, and Hele, Devon.

1895-1901. Leclurel in Chemistry, University College, Nottingham. Sinee 100L, Professor of Chemistry, and siuce 1908. Dean of Faculty of Scione. Univorsity College of Wales, Aberystwyth.

1894-(;, Demonstrator in Chemistry. Yorkshire College. 1896-1900, Researeh Chemist to the Aluminium Co. of London and Oldbury. Since 1900 with the Cassel Cyanide Co., Glasgow.

D.Sc. London (18!) 4 ,

F.R.S.E. (1895),

F.Pll.S.L.

Assoeiate, University Collesce, Bris

tol (1894)

Ph.D. Munich (1893),

F.I.C. $(1895)$

$(1905)$
Professor of Experimentul Physies, University College, Nottingham. Author of "A l'ext Book of Sound" (1908).

Worked for several years in the $x$-Ray Laboratory and also in the Physics Laboratory at University College, Bristol.

Decased. Formerly in the employ of the Newcastle Breweries, Ltd.

1895-6, Lecturer on Chemistry. Hull Techuical Sehool. 1896-1909, Chicf Chenist to Messrs. Barry, Ostlere \& Co. (now Barry, Ostlere \& Shepherd), linolcum manufacturers, Kirkcaldy. Now consulting Chemist in Leeds. Has published a book on the Chemistry of Fire and Fire Pre. vention. 
LIST OF SCIENCE RESEARCH SCHOLARS APPOINTED BETWEEN THE YEARS 1891 AND 1910-continued.

\begin{tabular}{|c|c|c|c|c|c|}
\hline Name of Scholar & $\begin{array}{c}\text { Years of tenure of } \\
\text { Scholarship }\end{array}$ & Places of study duriug Scholarship & $\begin{array}{l}\text { Branch of Science } \\
\text { and Principal subjects of Recarch } \\
\text { during tenure of Scholarship }\end{array}$ & $\begin{array}{l}\text { Degrees and other dis- } \\
\text { tinctions obtained } \\
\text { since appointment to } \\
\text { Scholarstipi }\end{array}$ & $\begin{array}{l}\text { Particulars of Scholar's subsequent career } \\
\text { ns far as ascertaincl }\end{array}$ \\
\hline $\begin{array}{l}\text { 10. Holt, Robert } \\
\text { Nominated by University College, } \\
\text { Liverpool (now University of } \\
\text { Liverpool) }\end{array}$ & $1891-3$ & University College, Liverpool & $\begin{array}{l}\text { Mochanieal Engincering. - Thermo- } \\
\text { dynamies of the stenm engine. Fffeet } \\
\text { of heat on the strongth of springs } \\
\text { and of metals generally }\end{array}$ & - & $\begin{array}{l}\text { Viee-Prineipal and Professor of En- } \\
\text { gineering in the Engineering Col- } \\
\text { lege, Gizeh, Egypt. Reeeived } \\
\text { deeoration of 4th Usmanioh from } \\
\text { H.H. the Khedive of Egypt. Mem- } \\
\text { ber of Bridges Commission, Egyp- } \\
\text { tian Government, Cairo. Consulted } \\
\text { as expert on strueture of Govern- } \\
\text { ment buildings for the Egyptian } \\
\text { Government. Aeted as Govern- } \\
\text { ment Inspeetor of Delta Light } \\
\text { Railway Company. President of } \\
\text { Fire Comnission. and advising } \\
\text { expert on school buildings to Ministry } \\
\text { of Lublie instruetion. }\end{array}$ \\
\hline $\begin{array}{l}\text { 11. Hoylcs, Annie J., B.Se. } \\
\text { Nominated by Fin' } \\
\text { field (now Universits of Sheffield) }\end{array}$ & $1891-3$ & $\begin{array}{l}\text { Firth College and University } \\
\text { College of Liverpool }\end{array}$ & $\begin{array}{l}\text { Magnetism.-Permeability of various } \\
\text { kinds of steel under different degrees } \\
\text { of nagnetisation }\end{array}$ & - & $\begin{array}{l}\text { Married shortly after expiration of } \\
\text { Selolarship. Since deecased. }\end{array}$ \\
\hline $\begin{array}{l}\text { 12. Parker, Franke Herbert. } \\
\text { Nominated by University College } \\
\text { of South Wales and Mon- } \\
\text { monthshire, Cardiff }\end{array}$ & $1891-3$ & $\begin{array}{l}\text { University College, Cardiff, and } \\
\text { Federal Polyteehinc, Zürich }\end{array}$ & $\begin{array}{l}\text { Physics.-Experiments on the heating } \\
\text { of the dielcetric of an electrie eon- } \\
\text { denser and on the propagation of } \\
\text { an electric wave in an artificial } \\
\text { submarine cablo }\end{array}$ & $\begin{array}{l}\text { B.Se. Iondon } \\
\text { A.N.I.L.L. } \\
\text { Fcllow of } \\
\text { Physieal Soeicty. }\end{array}$ & $\begin{array}{l}\text { 1898-1905, Lceturer in Mathematics } \\
\text { and Physics, Battersea Polytechnic. } \\
\text { Sinec } 1905 \text { Lecturer in Physics. } \\
\text { Woolwich Polytechnic. }\end{array}$ \\
\hline $\begin{array}{l}\text { 13. Moore, Benjamin, B.A. } \\
\text { Nominated by Queen's College, } \\
\text { Belfast (now Queen's Univcr- } \\
\text { sity of Bolfast) }\end{array}$ & $1891-3$ & University of Leiprig . & $\begin{array}{l}\text { Physienl Chemistry. Specd of reaction } \\
\text { in mixtures of isolyydric and non- } \\
\text { isohydric solutions of acids. Spced } \\
\text { of crystallisation from orer-eooled } \\
\text { liquids }\end{array}$ & $\begin{array}{l}\text { M.A. Royal Uni- } \\
\text { rersity of Ireland } \\
\text { (1592), } \\
\text { D.Se. Royal Uni- } \\
\text { versity of Ireland } \\
\text { (1902) }\end{array}$ & $\begin{array}{l}\text { 1891-8, Assistant Professor of Physio- } \\
\text { logy, Univcrsity College, London. } \\
1898-1900 \text {, Professor of Physiology, } \\
\text { Yale University, U.S.A. 1900-2, } \\
\text { Iecturer on Pliysiology, Charing } \\
\text { Cros Medical School, London. } \\
\text { Since } 1902 \text { Professor of Bio-chem- } \\
\text { istry, University of Liverpool. }\end{array}$ \\
\hline $\begin{array}{l}\text { 14. Dunn, Frederick William, B.A. } \\
\text { Nominated by Royal College of } \\
\text { Seience for Ireland }\end{array}$ & $1891-2$ & University of Glasgow & $\begin{array}{l}\text { Physies.-Bchaviour of electrostatie } \\
\text { instrunents under different eondi- } \\
\text { tions; produetion of hcat in an } \\
\text { olectrolytie cell }\end{array}$ & - & $\begin{array}{l}\text { 1892. Assistant Examiner: } 1904 . \\
\text { Deputy Examiner, H.M. Patent } \\
\text { Ofliee. Also called to the Bar in } \\
\text { 1908. }\end{array}$ \\
\hline
\end{tabular}


16. Evans, Peroy Norton, B.So. . Nominated by McGill University, Montreal

16 Steole, William Huoy, B.A. Nominated by University of Melbourne

17. Hcrbcrtson, Andrew John Nominated by University of Edinburgh

18. Henderson, James Blacklock, B.Sc. Nominated by University of Glasgow

19. Macdnnald, John, M.A., B.Sc. Nominated by University of Aberdeen der $\beta$-Diketone nit Harnstoff, Guanidin und Thio-harnstoff

1891-3

University of Melbourne.

Electricity.-Conductivity of a solution of copper sulphate. The physical of copper sulphate. The physical electric phenomenon. Thermoelectric constants of some puro metals

$1892-4$

Ben Nevis Observatory and

University of Montpellicr

Physics.-Hygrometry of the atmospherc

$1892-4$

Universities of Glasgow and Berlin offects of mechanical stress on the elcctrical resistancc of liretals. Polarisation of platinum elcctrodes magnetic fields on the cloctric con.
University of Jens . . . Chenistry.-The preparation and the study of certain derivatives of pyrazole with a view to deciding tho question of the constitution of pyrazole
Ph.D. Leipzig

M.A. Melbourno

Ph.D. Freiburgim-Breisgau,

M.A. Oxford

Ph.D. Jena (1894)

D.Sc. Glasgow (1897)
Professor of Chomistry and Director of the Chomical Laboratory, Purduo Univorsity, Lafayette, Indiana. 1910, President, Indiana Academy of Soience.

No longer cngaged in scientific work. Formerly Lccturer on 'Techuical kileetricity, Ballarat Sehool of Mincs, Victoria.

1894-6i, Lcctures in Gcography, Owens Colle to turen College, Manchester. 18.9-9, Lreturer in Commercial Gcography, Heriot-Wat College, Edinburghr. 1899-1901, Assistant to the Reader in Gcography, University of Oxford. 1901-5, Lecturer on Regional Gcograplsy, University of Oxford. Sincc 1905 Readcr in, and sinco 1910 Professor of Geography in tho University of Oxford. Member of Royal Comnission on Canals and Inland Waterways. Assistant Honorary Secretary, Rosearch Dcpartment of the Geographical Socicty, and Honorary Sccretary, Geographical Association. 1910, Prcsident, Scction F, British Association. in sulphuric acid. On the effects of
1894-8, Assistant Professor of Physics, Yorkshire Collegc, Leeds. 18981901, Hcad of Scientific Staff, Messrs. Barr \& Strouds, Admiralty Contractors, Glasgow. 1901-5, Lecturer in Electrical Enginecring, Univcrsity of Glasgow. Since 1905 Professor of Applied Mcchanics, Royal Naval College, Greenwich.

1894-9, Science Master at Georgo Watson's College, Edinburgh. Since 1899 Rector of the High School, Dunfermline, and Director of Studies at the Lauder Technical School. Also since 1907 an Examiner for degrees in Arts, Scicnce, and Medicine at St. Andrews University. 
LIST OF SCIENCE RESEARCH SCHOLARS APPOINTED BETWEEN THE YEARS 1891 AND 1910-continued.

\begin{tabular}{|c|c|c|c|c|c|}
\hline Name of Scholar & $\begin{array}{c}\text { Years of tenure of } \\
\text { Scholarship }\end{array}$ & Places of study during Scholarship & $\begin{array}{l}\text { Branch of Science } \\
\text { and Principal subjects of Rescarch } \\
\text { during tentre of Scholarship }\end{array}$ & $\begin{array}{l}\text { Degrees and other dis- } \\
\text { tinctious obtaincd } \\
\text { since appointment to } \\
\text { Scholinrship }\end{array}$ & $\begin{array}{l}\text { Particulars of Scholar's subsequeut career } \\
\text { ns far as ascertaincel }\end{array}$ \\
\hline $\begin{array}{l}\text { 20. Marks, Lionel Simeon a cience } \\
\text { Nominated by Mason } \\
\text { College, Birmingham (now } \\
\text { University of Birmingham) }\end{array}$ & $1892-4$ & Cornell University & $\begin{array}{l}\text { Mechanical Engineering. - Investiga- } \\
\text { tions in mechanical engineering, } \\
\text { and on strength of magnesium and } \\
\text { its alloys }\end{array}$ & $\begin{array}{l}\text { M.M.E. Cornell } \\
(1894)\end{array}$ & $\begin{array}{l}\text { Professor of Mechanical Engineering } \\
\text { at Harvard Univelsity sinee 1908; } \\
\text { formerly Assistant Professor. }\end{array}$ \\
\hline $\begin{array}{l}\text { 21. Thomas, George Lester } \\
\text { Nominated by University College. } \\
\text { Bristol (now Universit: of } \\
\text { Bristol) }\end{array}$ & $1892-4$ & $\begin{array}{l}\text { University College, Bristol ; Uni- } \\
\text { versity of Leipzig }\end{array}$ & $\begin{array}{l}\text { Physical Chemistry.-Researclies on } \\
\text { vapour pressures and specific volumes }\end{array}$ & - & $\begin{array}{l}\text { 1896-1902, Physics Master, St. } \\
\text { Olare's School, Southwarli. 1902. } \\
\text { Assistant Master, Pretoria Collegu, } \\
\text { Transval. During 1908 Acting } \\
\text { Lweturer in Mathematics, Trans. } \\
\text { val University College. April 1909- } \\
\text { April 1910, Acting Head Master. } \\
\text { Pretoria Colloge. }\end{array}$ \\
\hline $\begin{array}{l}\text { 22. Mann, Harold Hart, B.Sc. } \\
\text { Nominuted by Yorkshirc College, } \\
\text { Leeds (now University of Leeds) }\end{array}$ & $1892-4$ & $\begin{array}{l}\text { Yorkshire College and Labora- } \\
\text { tory of Biological Chemistry } \\
\text { of the Sorbonne, Paris }\end{array}$ & $\begin{array}{l}\text { Chemistry. - Chemistry of flames. } \\
\text { Action of certain antiseptic substances } \\
\text { on ycast }\end{array}$ & - & $\begin{array}{l}\text { After a successful eareed as Chemist } \\
\text { to the Indian Tea Association he was } \\
\text { appointed head of the Poona Agri- } \\
\text { cultural College, and Agricultural } \\
\text { Chemist to the Government of Bom- } \\
\text { bay. }\end{array}$ \\
\hline $\begin{array}{l}\text { 23. Conroy, James Tercnce, B.Sc. } \\
\text { Nominated by University College, } \\
\text { Liverpool (now University of } \\
\text { Liverpool) }\end{array}$ & $1892-4$ & $\begin{array}{l}\text { University College, Liverpool, } \\
\text { and University of Göttingen }\end{array}$ & $\begin{array}{l}\text { Chemistry. - Rescarcl on the constitu- } \\
\text { tion of Liebcrmann's colour and } \\
\text { other rescarches in organic chemistry }\end{array}$ & $\begin{array}{l}\text { Ph.D. Göttingen } \\
(1894)\end{array}$ & $\begin{array}{l}\text { Since Dccembcr } 1894 \text { Resenrch Chemist, } \\
\text { United Alkali Co., Ltd., Widnes. }\end{array}$ \\
\hline $\begin{array}{l}\text { 24. Lamb, Thornton Charles } \\
\text { Nominated by Owens College. } \\
\text { Manchestcr (now Victoria } \\
\text { University of Manchester) }\end{array}$ & $1892-4$ & $\begin{array}{l}\text { Owens College and University } \\
\text { of Heidclberg }\end{array}$ & $\begin{array}{l}\text { Chemistry. - Rescarches on atomic } \\
\text { weights of palladium and platinum } \\
\text { metals and on volatilisation of } \\
\text { various substances at ordinary tem- } \\
\text { peratures. Determination of the } \\
\text { melting points of inorganic salts }\end{array}$ & $\begin{array}{l}\text { Ph.D. Heidelberg } \\
\text { (1895) }\end{array}$ & $\begin{array}{l}1895 \text {, entered Mcssrs. Brunner, Mond \& } \\
\text { Co.'s cmploy and since } 1896 \text { Manager } \\
\text { of their Works, Silvertown, London. }\end{array}$ \\
\hline $\begin{array}{l}\text { 25. Nedley, Edward Arnold } \\
\text { Nominated by University College, } \\
\text { Nottingham }\end{array}$ & $1892-4$ & $\begin{array}{l}\text { Central 'l'eclinical Collegc, South } \\
\text { Kensington }\end{array}$ & $\begin{array}{l}\text { Electricity. - Investigations in the } \\
\text { economics of elcctric incandescent } \\
\text { lighting and photometry }\end{array}$ & - & $\begin{array}{l}\text { 1894-5, Assistant to the late Professor } \\
\text { W. E. Ayrton, F.R.S., in investiga- } \\
\text { tions on improvcments in the inanu- } \\
\text { facture of elcctric lamps. 1895-7, } \\
\text { carried out a series of investigations } \\
\text { in London and Berlin on improve- } \\
\text { ments in elcctric and gas incan- } \\
\text { descent lamps for the Langhan's }\end{array}$ \\
\hline
\end{tabular}


26. Oates, William Henry

Nominated by Firth College, Shef field (now University of Shefficld)

27. Jones, Edward Taylor, B.Sc. Nominated by University College of North Wales, Bangor

28. Ryce, George $\cdot$ ' Nominated by Queen's College, Cork (now Corli)

29. Gannon, William, M.A. Nominated by Queen's College Galway (now University College, Galway)
Chemistry.-Determination of amount of sulphur-dioxide in fogs. Research on the dibromonaphthalenes

$1892-\tilde{5}$

$1892-3$

$1892+4$
University College of North

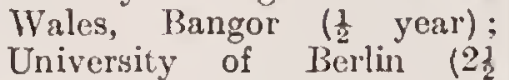
years)

Proyal College of Science, Lonlon

lectrieity and Magnetism.-Experiments to determine the true relation between eleetro-magnetic

Chemistry$$
\text { . }
$$

Electricity.-Copper electrolysis in vacuo. Specitic heat of water in cerms of the international electric units stress or tractive force per unit area of magnets and magnetisation
Patent Syndicate, Ltd. 1897-1902, employed by the Premier Electric Lamp Co., Ltd., ins an expert in the manufacture of incandeseent electrie lamp nlaments and as works inanager. since 1902, of Fowlcr \& Medlcy, Electrieal and Mechanieal Engineers, Great Crosby, Liverpool. Manufacturer of the Fow ler-Medley Patent Suction Gas Plants and of the Fowler-Medley Patent T'ar Lxtractors and Gas Serubbers, and of apparatus for treating gases and vapours with liquids.

Engaged in research in Chemistry at University College, Sheffield. from 1894 to 1903 , when he discontinued scientifie work.
D.Sc. Lonelon $(1905)$

A. Royal UniA.R.C.S.

(Chemistry and Agrieulture) First Class

Diploma of the Royal Agricultural Society of

England.
1806, Assistant Lecturer in Physics and Electrical Engineering; and since 1900, Professor of Thysics, Unirersity College of North Wales, Bangor.

Formerly held teaching posts at Royal College of Science, London, and Agrieultural College, West Lavington; also aeted as Agricultural Instruetor and Analyst under Devon County Council; and later as Organising Secretary for County Kildare under the Department of Agrieulture for Ireland. Now agent in Dublin for the Potash Syndicate, Stassfurt, Germany.

1894-6; Assistant Lecturer and Dcmonstrator in Physics, Owens College, Manchester. 1896-9, Seience Leeturer and Inspector under the Stafford County Council. 1899-1903, Principal of Norwich Icclinical Institute. Since 1903 Principal of Woolwieh Polyteehnic. 
LIST OF SCIENCE RESEARCH SCHOLARS APPOINTED BETWEEN THE YEARS 1891 AND 1910-continued.

30. Smale, Frederick J., B.Sc. Nominaled by University of Toronto

31. Allen, James Bernard, B.Se

Nominated by University of Adelaido

32. Jackson, David H., M.A., B.Se. Nominated by University of New Zoaland

33. Barraclough, Samuol Henry, B.Eng. Nominated by University of Sydney

34. Bolam, Herbert William, B.Sc. Nominatcd by University of Edinburgh
I'laces of study during Scholarship

Universities of Leipzig and

Göttingon

University of Sydnoy

$1892-4$

$1892-5$

University of Mclbourne; Royal College of Science. London University of Heidelberg

$1892-5$

Cornell University and University of Sydney

$1893-6$

Universities of Loipzig (25 years) and Edinburgh ( $\frac{1}{3}$ year)

\section{and Principal subjects of Researeh
during tenure of Seholarship}

Chemistry.-Theory of gas batteries from the standpoint of the dissociation theory. Measurements of dielectric constants Conditions of

the solution of uric acid in urino

$$
\begin{aligned}
& \text { Physics.-A } \\
& \text { sulphur }
\end{aligned}
$$

A serias of oxperimonts on

Chemistry.-Hyponitrites. The pro pertios of canarin. Hydrobenzone derivatives

$$
\text { (n) }
$$

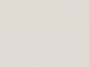

(10)

Techanieal Engincering.-Effect of temperature on readings of steamengine indicators. Heat losses to cylinder walls of ongines. Investigations in hydraulies

Chemistry.-Optically activo mothoxyand propoxy-succinie acids. Saponifieation products of dicarboxyllie glutaconic ether. Reduction of imido ethers
Degrees and other dis-

tinctions obtainct Scholarslipip
Sches

Ph.D. Iseiprig

Until
Particulars of Seholar's subseyneut career
is for as ascertained

Until his dcath in 1908, oecupied an important position in a largo inclustin business as technical expert.

Lecturer on Mathematics and Physies in the 'Tochnieal School, Perth, Western Australia. Formerly Assistant Iecturer and Domonstrator in Iathematies and Physics, University of Adelaide.

I'h.D. Hoidelberg

1895-(i, Rescarch Assistant, Pharmaceutical Society's Laboratories (London). 1896-7, Assistant in Scientifie Department, Imperial Institute. 1897-1900, Lseeturer at University Collcge, Bristol. 1900-2, Lecturor at Birkbeek College (London). Sineo 1902 Hcad of a Consulting Practice, London.

M.M.E. Cornell, A.M.I.C.E.

Assistant-Professor in the Faculty of Scienoe and Lecturer in Mechanioul Enginecring, University of Sydney.

Ph.D. Loip\%ig

1898-1900, Assistant Lecturer, and 1900-4, Principal Lecturer in Chemistry, Leith Teelnnical College. Nince 1903 Leeturer in Chemistry, Queen Margaret College, University of Glasgow. 
3i. Allan, George Edwin, B.Se.

Noninated by University of Glasgow

36. Walker, James Wallace, M.A Nominaled by University of St. Androwa

37. Lapworth, Arthur, B.Sc. Nominated by Mason College, Birminghain (now University of Birmingham)

38. Myers, John Ellis, B.Sc.

ominated by Yorkshire College, Lceds (now University of Leeds)

39. Titherlcy, Arthur Walsh, B.Sc. Nominaled by University College, Liverpool (now University o Liverpool) ity and Magnerism_-Contact differences of potential between metals. Mersurement of the attraction of thin magnotic filaments

1893-6

Universities of St. Andrews and Leipzig, and Contral Technieal College, South Kensing ton

$1893-5$

Central Technical College, South Kensington

$1893-6$

University of Strassburg . . Physics.-Investigations of the silver

University College, Liverpool, and University of Hcidelberg oltameter and of Faraday's law of electro-chemical equivalents. Dc-
composition of silver salts whon composition of silver salts whe
exposed to hydrostatic pressure

Chemistry.-Active lactie acids and the rotation of their metallic salts in solu. tion. Ethereal salts of optically active lactic, chloropropionie, and bromopropionic acids. Optical activity of mandolic acid and its salts in solution

Chemistry.-Action of acid chlorides on nitrates. Sulphonie aeids of thalene, \&c.

Chemistry.-Amides of sodium, potas. sium, and lithium. Glutaric derivative betamathoxy- and betaetloxy-naph-
(1903)

Ph.D. Loipzig

D.Sc. London (1896),

$$
\text { F.I.C. }
$$

F.R.S. (1910)

I.Sc. Victoria, Ph.D. Strassburg

Ph.D. Heidclberg (1895),

M.Se. Victoria (1896),

D.Se. Vietor

(1901),

D.Se. Liverpool

(1904)
895-1903, Assistant to Professor of Physics, University of Birmingliam. Since 1905 Leeturur on Optics, 'TcehHnivollege, Glasgow. Also, 1906-8, Philosoplyy and sint in Natural in Electicity, Unirco lons Leoturer in Electricity, University of Glasgow.

Professor of Chemistry, Mccill Univorsity, Montrual.

1895, Lecturer in Chemistry, School of Pharnacy, Bloomsbury Square. 1900, Head of Chomistry Depart. ment, Goldsmiths' Institute, Now Cross. 1906-1909 Lecturer in Chemistry and Sceretary of Scicnco Dopartment at the Goldsmiths' Colloge, University of London. 1909, Union Lecturcr and Demonstrator and Assistant Dircetor of the Inorganic Laboratories, University of Manchester. Schunck Fellow, University of Manchester. 1910, Fellow of the Royal Socicty.

\section{Deceased.]}

1897-1905, Assistant Leeturer in Chemistry, University College, Liverpool. Since 1905 Locturur in eliarge of Department of Organic Chemistry, University of Livorpool. Examincr in Chemistry for Liverpool University and Joint Matriculation Board. Has served on education committees, governing bodies of

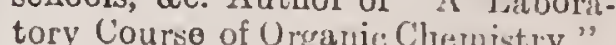


IIST OF SCIENCE RESEARCH SCHCOLARS APPOINTED BETWEEN THE YEARS 1891 AND 1910 -continurl.

\begin{tabular}{|c|c|c|c|c|c|}
\hline 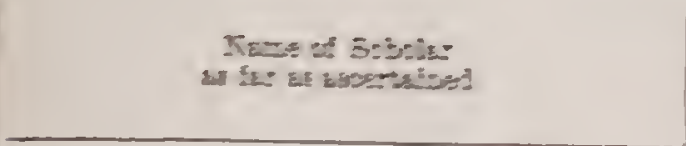 & $\begin{array}{l}\text { Tears of ienure } \\
\text { of Scholarebis }\end{array}$ & Plares of study durinitg Schoinship & $\begin{array}{l}\text { Branch of Science } \\
\text { ami Principas suljects of Research } \\
\text { luring tenure of Scholarship }\end{array}$ & 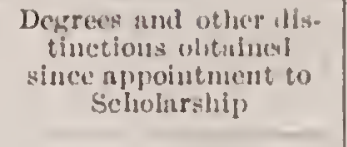 & 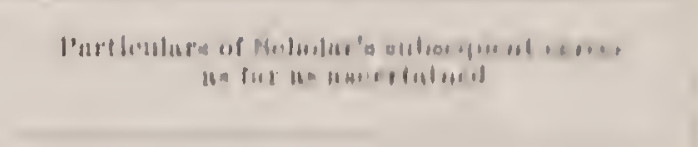 \\
\hline 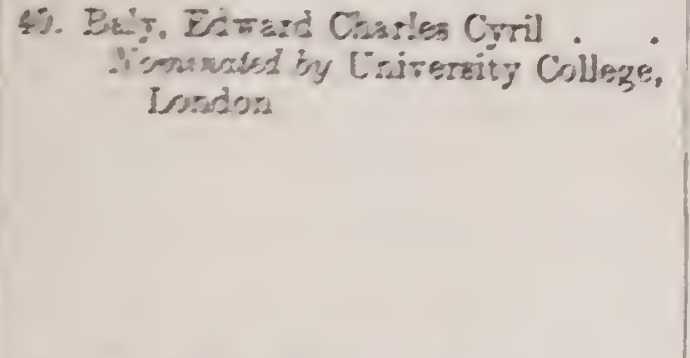 & $1893-h$ & Univernity Colloggt,, London & $\begin{array}{l}\text { Physical Chomistry. - Rclations of } \\
\text { pressure, volume, and tomperaturo } \\
\text { in rarofied gases. Action of nitric } \\
\text { acid on the lignocelluloses. In- } \\
\text { vestigation of two-fold spectra of } \\
\text { rarefied oxygon and nitrogen. At- } \\
\text { tempt to decompose these gases }\end{array}$ & $\begin{array}{l}\text { Fellow of Univ. } \\
\text { Coll. Tondon } \\
(1907) \\
\text { F.12.s. }\end{array}$ & 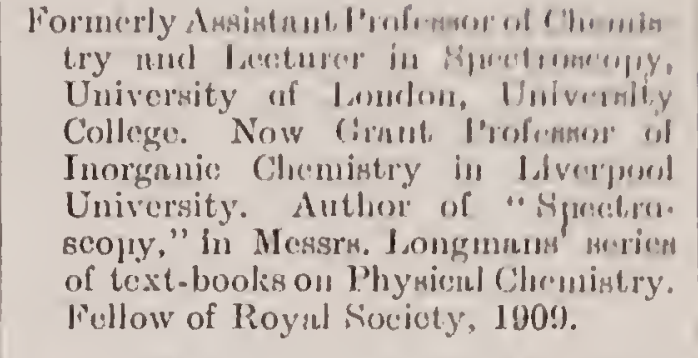 \\
\hline 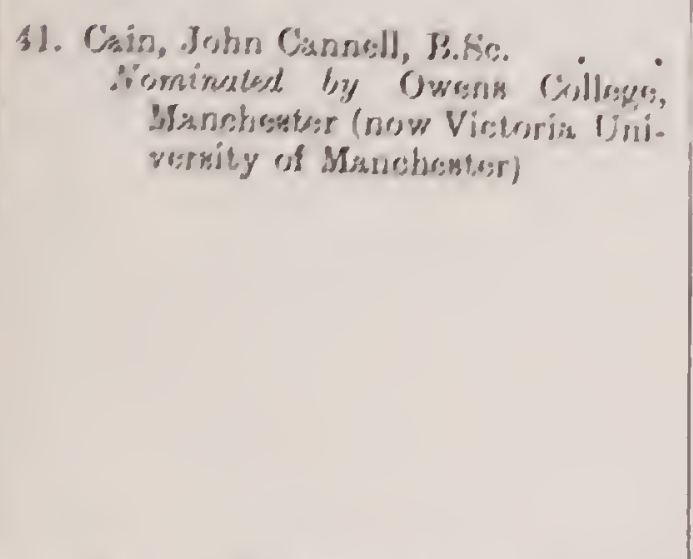 & $1898: "$ & 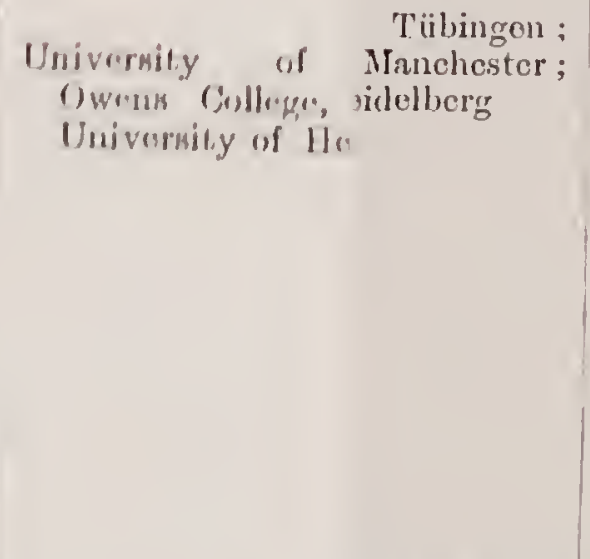 & $\begin{array}{l}\text { Chomistry. - Instantancous pressures } \\
\text { t produced in tho oxplosion of gases. } \\
\text { Incomplete combustion of gases. } \\
\text { Rescarch on durol derivatives }\end{array}$ & $\begin{array}{l}\text { D.Sc. Tübingen } \\
\text { (1893), } \\
\text { M.Sc. Victoria } \\
\text { (1902), } \\
\text { 1..Sc. Victorin } \\
(1904)\end{array}$ & 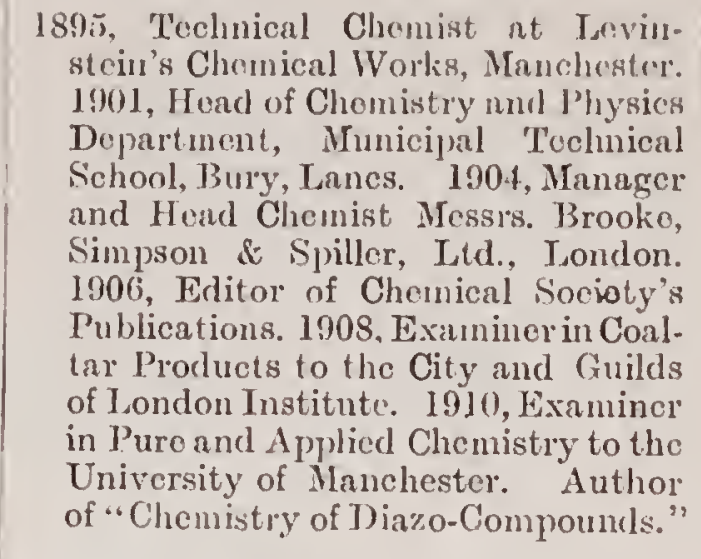 \\
\hline 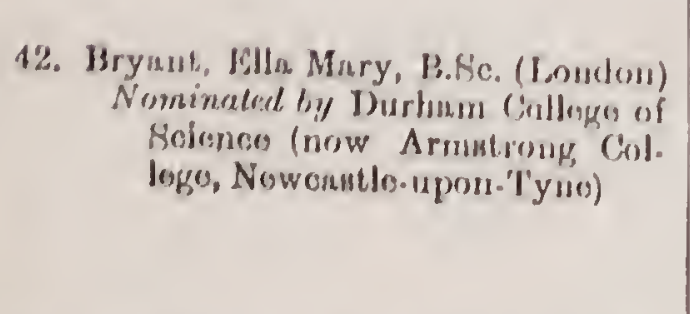 & In:1,is-nit & 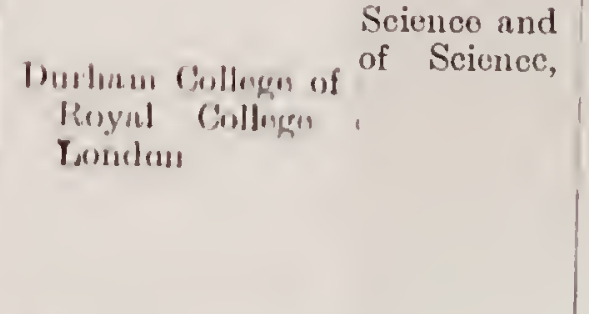 & $\begin{array}{l}\text { Physies.-Investigation of temperature } \\
\text { of boiler plates by olcctrical mothods }\end{array}$ & $\begin{array}{l}\text { B.Se. Durham, } \\
\text { II.Se. Durham } \\
\text { (1899) }\end{array}$ & $\begin{array}{l}\text { 1898, Scnior Mistress, County School, } \\
\text { Blacnnu Hestiniog, Nortl Wales. } \\
1901 \text {, SeniorScience Mistress, Dulwich } \\
\text { High School. 1902, Scnior Science } \\
\text { Mistress, Shefficld High School. } \\
\text { 1905, Senior Science Mistress, Kings- } \\
\text { land L.C.C. Sccondary School. }\end{array}$ \\
\hline $\begin{array}{l}\text { 43. Oranger, Jamos Darnoll, A.I.C. } \\
\text { Nominaled by Universily Colloge, } \\
\text { Nottinghain }\end{array}$ & $18993-5$ & University of Berlin & $\begin{array}{l}\text { Chemistry.-Preparation of } \beta \text {-propyl- } \\
\text { piperidine }\end{array}$ & $\begin{array}{l}\text { Ph.D. Berlin } \\
\text { (1896) } \\
\text { F.I.C. J.ondon }\end{array}$ & $\begin{array}{l}\text { Analytical Chemist in large soap works, } \\
\text { Germany. }\end{array}$ \\
\hline $\begin{array}{l}\text { 14. O'Brim, Mary, B.So. (Mr'. O'Brien } \\
\text { Harrig) } \\
\text { Nominated by Univerwity Collego } \\
\text { of Walen, Aberystwyth }\end{array}$ & $18: 13-5$ & $\begin{array}{l}\text { Botany School, Us } \\
\text { Oxford }\end{array}$ & Botany.-Tho proteids of wheat & D.Sc. London & $\begin{array}{l}\text { 1895-1906, Assistant Mistress under the } \\
\text { late School Board for London and } \\
\text { under the I.C.C. in Higher Grade and } \\
\text { Polytechinic Schools. Since } 1906 \text { Head } \\
\text { Mistress of L.C.C. Secondary School. }\end{array}$ \\
\hline
\end{tabular}


45. Donnan, Frederiek George Nominated by Queen's College, Bclfist (now Queen's University of Belfast)

46. MaePhail, James Alexander, B.Se. Nominated by MeGill University, Nontreal

47. Carmiehael, Norman Ross, M.A. Nominated by Qneen's University, Kingston, Ontario

48. Ledger, William Henry, B. Eng. Nominated by University of Sydney

49. MaeDonald, George Willian, B.Se. Nominated by University of MIelbot!rne

50. Beattie, John Carruthers, B.Se. Nominated by Univorsity of Edinburgh
Physical Clemistry.-Plotometric investigation of the electrostylic dissociation of violuric acid in alyucou solution, and of the effects produced thereon by other organic acids

T.A. Royal Uniersity of Ireland (1894).

Ph.D. Leiprig (1896)

Versuchs-Anstalt, Charlottenburg, and University of Heidelberg

$1893-5$

Johns Hopkins Unirersity, Baltimore

$1803-5$

Cornell University . . . Civil Enginecring.-Bridge ongineering

1893-(i; (2 years)

University of Mclbourne and University College, London

$1894-7$

Civil Engincering.-Influcnee of temperature on strength of matcrials, \&.

Elcetrieity. - Various rcsearehcs in electrieity

Chemistry.-Interaetion of nitrie oxide and sodium ethylate. Whethor argon is eontained in animal or vegetable substanees. Production of cyanides at the tomperature of the eleetrie arc

Eleetricity and Mrgnetism. - Eleetrieal and Glasgow

1897, Junior Fellow, Royal University of Ircland. 1900, Assistant Profcssor of Chemistry, University Collegc, London. 1903, Lecturer in Organic Chomistry. lioyal Collego of Scienoe, Dublin. Since 1.004 Professor of Thysical Chcmistry, University of Liverpool, and Director of the Muspratt Laboratory of Plysiea and Eleetro-Chemistry. research and partieularly the beresearch, and pertion haviour of conduetors inl a steady magnetie field when traversed at tinuous eleetrie eurrent
M.C.E. Corncll B.Se, Adelaid

M.Se. Melbourne

Professor of Gencral Engineering, Quecn's University, Kingston, Ontario.

Until his death, in 1908, Assistant Professor of Physies, Sehool of Mining, Kingston, Ontario.

Lecturer in eharge of Engineering and Surveying Departments at South Australian Sehool of Mincs.

1896, Chemist to Messrs. Pigou. Wilks \& Laurence, Explosive Works, Dartford, Kent. 1898, Manager of sime on ineorporation with Messrs Curtis's \& Harvey, Ltd. 1908, appointed by Messr's. Curtis's \& Harvey, Lidl, Head of their lie. seareh Department.

D.Se. Edinburgh F.R.S.E.

Sinec 1897 Professor of Physies, Sout Afrienn College, Cape Town. Pas President South Afriean Philosophieal Soeiety. Member of Couneil of University of Cape of Good Hope, Nember of Couneil of South Afriean Assoeiation for the Advaneement of Seienee. Member of Meteorologieal Commission of Cape Colony. Member of Couneil of Royal Soeiety South Afriea. 
LIST OF SCIEITCE RESEARCH SCHOLARS APPOINTED BETWEEN THE YEARS $189 \mathrm{l}$ AND 1910-continucd.

\section{Name of Scholar}

51. Erskine-Murray, James Robert, B.Se.

Nominated by University of Glasgow

52. Davidson, William Brown, M.A., B.Se.

Nominated by University of Aberdoen

53. Clinker, Reginald Charles Nominated by University College Bristol (now University o
Bristol)

54. Dent, Frankland, B.So., A.I.C. . Nominated by Yorkshire College, Leeds (now University of Leeds)

\begin{tabular}{|c|c|c|}
\hline $\begin{array}{l}\text { Years of tenure } \\
\text { of Seloolissship }\end{array}$ & Places of study during Seholarship & $\begin{array}{l}\text { Branch of Science } \\
\text { anul Principal subjects of Research } \\
\text { during tenure of Sclolarship }\end{array}$ \\
\hline 394 & iversities & \\
\hline
\end{tabular}

$1894-6$

niversities of Glasgow and Cambridge the thermal conductivity of rocks. Eifect of Rïntgen rays on the contact elcctricity of metals and othor resorrches on contact electricity

$1894-7$

Universities of Würzburg and Leipzig

$1894-6$

University College, Bristol, and University College, London

$1894-6$

Chemistry. - Diazophenols, catalytie actions, \&c. Diazouium liydrate, diazotates, isonitro compounds

E

- Dotermination of the specific induetive eapacity and tho hysteresis of dielectries. Design of, and experimonts with, an apparatus University of Munich . . . Chemistry. - Nitro- and nitroso-ure-
Physics. - Tompcrature variation of

\begin{tabular}{l} 
Decres and other dis- \\
tinetions obtuineel \\
since appointment to \\
Scholarship \\
\hline
\end{tabular}
Fellow of Phys

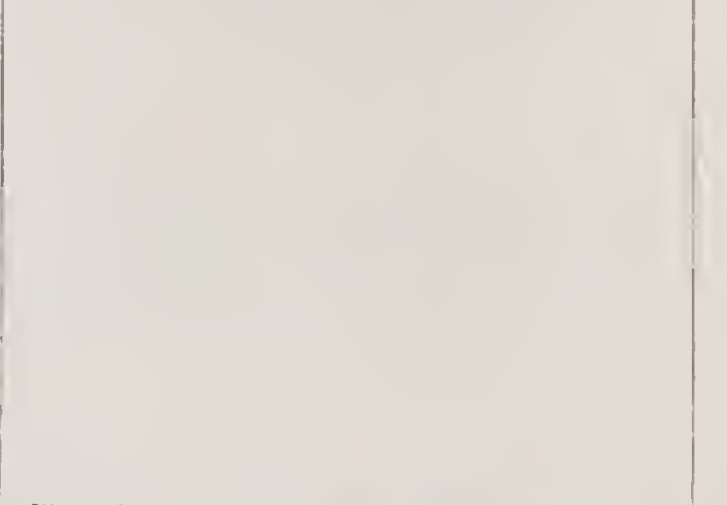
thanes
D.Sc. Giasgow, F.R.S. E M.I.E.E. Soc.

Particulars of Sclolar's subsequent career is far as aseertained

1896-8, Assistant Professor of Applied Physies and Elcetrical Engineering. Heriot-Watt College, Edinburgh. 1898-1900, ehief Experimental As sistant to Mr. Marconi. 1900-4, Jecturer on Physies and Electricity, University College, Nottinghain. 1904-5, Science and Nathematics Mastcr, Kelvinside Academy, Glasrow 1905-7, Consulting gow. 1. Ever Collo Sin in Colsor tolectical Engineer and Raciotolegraphist (Iondon). and Lecture on Wircless telceraphy and Telephony at the Northampton Polytechnio Institute, London.

Ph.D. Würzburg (1898),

D.Sc. Aberdeon (1899), F.I.C. (1900)

F.1.C. (1895), Sc.Victoria(1897) h.D. Munich

I.Se. Leeds (1905)
1898-1900, Assistant Lecturer and Demonstrator, Chemical Department, University College, Liverpool. 1900-2, Senior Demonstrator and Lecturer on Physical Chemistry, University of Aberdeen. 1903-5, First Class Research Chemist. Experimental Establishment, Woolwich Arenal. Sinee 1905 Chemist. to the Gas Committec, Birminglian.

Since 1896 Designing Engincer with the British 'llomson-Houston Co. Rugby.

1900-5, Chemist to Sicna Company, Limited, Burgos, Spain. 1905, Assistant Government Analyst, Singapore. $1906, \quad$ Government
Analyst, Straits Settlements. 
55. Ewart, Alfred James, B.Se. Nominated by University College. Liverpool (now University of Liverpool)

56. Morris, David King Yominaled by University Colloge. London

57. Frith, Julius Nominated by Owens College Janchester (now Victoriu University of (Ianchester)

58. Beattie, Robert, B.Sc. Nominated by Durhain College of Science (now Arunstrong Col lege, Newcastle-upon-'Tyne)
$1894-7$

University of Leipzig and Botanical Institute, Java

University College, London Nederal Polytechnic, Zürich

Owens College and Central Technieal Collegre, South Kensington
Botany.-Assimilatory inhibition in chlorophyllous plants. Acelimatisation and allied problems of economie botuny. Contact irritability. Evolution of oxygen from coloured bacteria

Ph.D. Loipzig

D.Se. Melbourne

D.Se. Oxfor

Plysies and Electrieal Enginecring.- Ph.D. Zürich Diclectric hysteresis. Ilensurement of varying eurents in iuductive eircuits Effot of auncling on physical properties of manganese steel. Magnetic properties of clectrical resistance of iron ias dependent upon temperature

Fellow of Univer-

sity College, Y,on-

Member of Phys.

Associate of American Institute of

Electrieity. - Devising a recording thermometer. Researehes on the resistance of the uloctric are; the effoct of wave forms on the alternate current are, \&c.

leetrieity and Magnetism. - Incan descent lamp tests. Design of, and experiments with, an apparatus for measuring magnetic hysteresis (1896),

D.Se. London (1897), (1907),

(1910)$$
\text { (1897) }
$$

don $(1897)$ soe. neers (1901)

1905. Professor of Botany, University of Melbourne, and Government Botanist. 1908. Chairnan of the Forest Examination Bonrd

1897-8, Senior Demonstrator in Electrieal Engineering, South - Western Polytcehnie, Chelsea. 1898-1906. Lecturer in Electrieal Engincering, Mason University College, Birminglram (now University of Birmingham). 1902-6, Conducted entire work of department, and dosiyned new laboratories of University Buildings at Bournoroot. Sinco 1900 Buint Proprictor and ifun Joint Propictor and Mn Th. Co lontry, now Lid., Covent y. electrient engineering appliances and inventions.

M.Se. (Hon.)

Vietoria

(1906i)

D.Se. Durham, II.I.E.E.
1896-1910, With Nather \& Platt. Engineers, Naneliester, and, 190:3-11. Head of their Electrieal Designing and Testing Departments. Since 1907 has given at the Manchester Munieipal sehool of Teehnology the fourth-year leetures on the design of diceet-eurront machinery. Now giving the fifth-year course on the design of alternating-eurrent machinery, on which subject he is writing a book. Has rocontly stanted writing a book. Was socktly started work as
engincer.

Sinee 1900 Demonstrator and Lecturer in Electrotechnies, Vietoria University of Nanchestor. 
LIST OF SCIENCE RESEARCH SCHOLARS APPOINTED BETWEEN THE YEARS 1891 AND 1910-continued..

\begin{tabular}{|c|c|c|c|c|c|}
\hline Name of Scholar & $\begin{array}{l}\text { Years of tenure of } \\
\text { Scholarship }\end{array}$ & Places of study during Scholarship & $\begin{array}{l}\text { Branch of Science } \\
\text { and Principal subjects of Research } \\
\text { during tenure of Scholarship }\end{array}$ & $\begin{array}{l}\text { Degrees and other dis- } \\
\text { tinctions obtainel } \\
\text { since appointment to } \\
\text { Scholarship }\end{array}$ & $\begin{array}{c}\text { Particulars of Scholar's subsequent career } \\
\text { as far as ascertained }\end{array}$ \\
\hline $\begin{array}{l}\text { 59. Burnie, William Beekit } \\
\text { Nominated by University College, } \\
\text { Nottingham }\end{array}$ & $1894-6$ & $\begin{array}{l}\text { Central Technical College, South } \\
\text { Kensington, and Federal } \\
\text { Polytechnic, Zürich }\end{array}$ & $\begin{array}{l}\text { Fileetricity and Magnetism.-Construe- } \\
\text { tion of apparatus for measuring } \\
\text { small magnetic permeabilities and } \\
\text { for determination of } \Lambda \text {.C. wave } \\
\text { forms. Expcriments on the effieiency } \\
\text { of A.C. arc and eauses of variation } \\
\text { with wave form. Experiments on } \\
\text { thermo-electric properties of liquid } \\
\text { metals }\end{array}$ & $\begin{array}{l}\text { B.Sc. London } \\
\quad(190.5) \\
\text { D.Sc. Yondon } \\
\quad(1907)\end{array}$ & 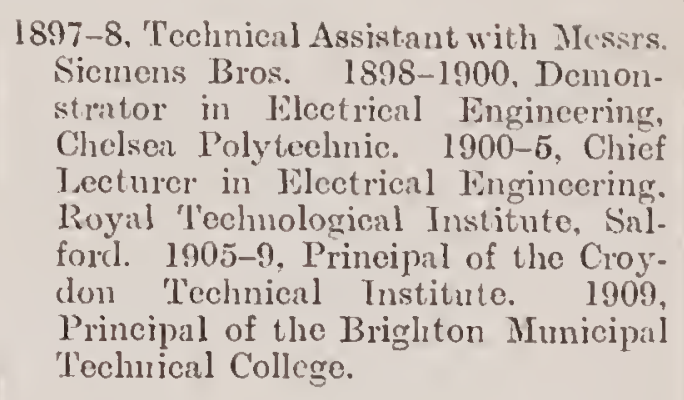 \\
\hline $\begin{array}{l}\text { 40. Rodgers, Charles, B.Sc. Lond. } \\
\text { Nominated by Firth College, } \\
\text { Sheffield (now University of } \\
\text { Sheffield) }\end{array}$ & $1894-6$ & $\begin{array}{l}\text { Central Technical College and } \\
\text { Federal Polyteohnic, Zürich }\end{array}$ & $\begin{array}{l}\text { Physics.-Construction of apparatus } \\
\text { for tracing wave forms of alternat- } \\
\text { ing eurrents, and various other } \\
\text { experiments in electricity and mag- } \\
\text { netism. Work on the resistance of } \\
\text { the clectric are. }\end{array}$ & $\begin{array}{l}\text { B. Fing. Shertiold } \\
\text { (1908) }\end{array}$ & $\begin{array}{l}\text { Since January } 1901 \text { witl } \\
\text { Bros. \& Co., Lidd., and Sicmens } \\
\text { Bros. Dynamo WVorks, Ltcl., cons- } \\
\text { moncing in designing and cxperi- } \\
\text { mental departments. In l904 } \\
\text { appointed elicf of alternating- } \\
\text { current designing department at } \\
\text { the Stafford Works of the latter } \\
\text { Company. Since the autumn of } \\
\text { 1905 in advising position on Manage- } \\
\text { ment Staff in Londou. }\end{array}$ \\
\hline $\begin{array}{l}\text { 61. McClelland, John Alexander, M.A. } \\
\text { Nominated by Queen's Collegc. } \\
\text { Galway (now University Col- } \\
\text { lege, Galway) }\end{array}$ & $1894-5$ & $\begin{array}{l}\text { Owens College, Manchester, and } \\
\text { University of Cambridgc }\end{array}$ & $\begin{array}{l}\text { Physies. - Speeifie inductive eapacity } \\
\text { of air. The leakage of dielcetrics } \\
\text { traversed by Röntgen lays. The } \\
\text { selective absorption of Röntgen rays }\end{array}$ & $\begin{array}{l}\text { M.A. Cambridge } \\
\quad \text { (IS98), } \\
\text { Fellow Royal Uni- } \\
\text { versity of Ireland } \\
\quad(1901), \\
\text { D.Sc. (Hon.) R.U.I. } \\
\quad(1906), \\
\text { F.R.S. (1909) }\end{array}$ & $\begin{array}{l}\text { Resigned Scholarship in } 1895 \text { on } \\
\text { obtaining Junior Fellowship in Roynl } \\
\text { University of 1reland. Worked in } \\
\text { Cavendish Laboratory until } 1900 . \\
\text { Appointed, 1900, Professor of Phy- } \\
\text { sies, University College, Dublin. } \\
1906 \text {, Sccretary Royal Irish } \\
\text { Academy. 1908, Senator of National } \\
\text { University. 1910, Commissioner of } \\
\text { National Education, Ircland. 1909, } \\
\text { Fellow of Royal Society. }\end{array}$ \\
\hline $\begin{array}{l}\text { 62. Kenriok, Frank Boteler, B.A. } \\
\text { Nominated by University of } \\
\text { Toronto }\end{array}$ & $1894-7$ & $\begin{array}{l}\text { University of Leipzig and Pri- } \\
\text { vate Laboratory of Profossor } \\
\text { van't Hoft, Berlin }\end{array}$ & $\begin{array}{l}\text { Physical Chemistry.-Potential differ- } \\
\text { ences betwcen gases and liquids. } \\
\text { The solubility and conditions of } \\
\text { existence of tachliydrite. The } \\
\text { raeenic transformation of ammonium } \\
\text { bimalate }\end{array}$ & $\begin{array}{l}\text { 1'H.D. Leipzig } \\
\text { (189(i), } \\
\text { M.A. Toronto } \\
\quad(1901)\end{array}$ & $\begin{array}{l}\text { 1897, Assistant; } 1900, \text { Lecturer : } 1907, \\
\text { Associate Professor of Chemistry, } \\
\text { University of 'Ioronto. }\end{array}$ \\
\hline
\end{tabular}


63. HoKittriok, Frederick James Alexander, B.Sc.

Nominated by Dalhousie University, Halifax, Nova Scotia

64. Gilchrist, John D. F., M.A., B.Sc. Nominated by University of Edinburgh

65. Stewart, Walter, M.A., B.Sc Nominated by University of Glas. gow

ff. Williamson, Henry Charles, M.A. B.Sc.

Nominated by University of St. Andrews

67. Henderson, James, B.Sc

Nominated by University College, Dundee

68. Pickard, Robert Howson, B.Sc. . Nominated by Mason College, Birmingham (now University of Birmingham)

69. Milner, Samuel Roslington, B.Se. . Nominated by Unirersity College, Bristol (now University of Bristol)
$1894-6$

$1895-6$

$1895-8$

$1895-7$

$1895-7$

January 1896 to Decembo 1897

1895-8 (2 years)
Cornell University . .
University of Edinburgl and
various Fishery Stations
Universities of Glasgow and Berlin

Marine Laboratories, Naples and Kiel

Polytcchnic Institute, Munich .

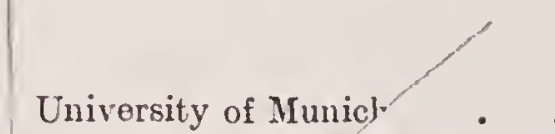

University College, Bristol, and University of Göttingen
Electricity.-Losses of energy in an iron ring subjected to alternating magnetic forces. Construction of Lotchkiss's galvanometer, and intherewith, \&e.

Food Fisheries. - Study of the nervous system of the mollusca, \&c.

Electricity and Magnetism.-Electrification of air. Damping effect of the inagnetic ficld on rotating insulators. Loss of weight of platinum and palladium wires in different Gases when raised to a higl temperaturc. Contact electricity

Food Fisheries. - Reproduction and development of the eel. Absorption of the yolk in teleostcan ova

Chemistry.-Action of diastasc enzymo and dilute acids on various dextrine and sugars

Chemistry.-Rescarches on indigo derivatives and hydroxamic acids

Plyysics. - Thermal conductivity of watcr. Surface tension of mercury under electrolytes
Sc. Edinburgh, Ph. D. Zürich

D.Sc. Glasgow (1898)

c. St. Andrews (1902),

T.R.S.E.

Ph.D. MIunich

h.D. Munich (1898),

A.I.C. (189S), D.Sc. Londor (1899).

D.Sc. London (1899)
Since 1905 Managing Director of the General Electric Company for: Australasia.

Appointed in 1906 Marine Biologist to the Government of the Cape of Good Hope ; subscquently Government Biologist. Now Professor of Zoology at the South African College, Capetown, and Chairman of the Fishery Board, Cape of Good Hope.

1899-1903, Chief Assistant to Professor of Natural Philosophy and Lecturer in Electricity (Pure and Applicd), University of Glasgow. 1903- 6 , Junior Inspector of Schools, and since 1906 H.MI. Inspector of Schools (Scotland).

Appointed, 1897, one of the Naturalists to the Fishery Board for Scotland.

For three years Lecturer in Organic Chemistry, MIcGill University, Montreal, and during the past seven years Chief Chemist to Horlick 's Malted Milk Co., Racine, Wis., U.S.A.

Lccturer on Chemistry (since 1899) and Principal (since 1908) of Municipal Technical School, Blackburn. Also Consulting Chemist and Gas Examiner to Corporation of Blackburn since 1900.

1898-1900, Junior Demonstrator, in Physics, Owens College, Manchester. Since 1900 Lecturer in Physics, University of Sheffield. 
LIST OF SCIENCE RESEARCH SCHOLARS APPOINTED BETWEEN THE YEARS 1891 AND 1910-continued.

\begin{tabular}{|c|c|c|c|c|c|}
\hline Name of Scholar & $\begin{array}{l}\text { Years of tcnurc } \\
\text { of Scholarship }\end{array}$ & Places of study during Scluolarship & $\begin{array}{l}\text { Branch of Science } \\
\text { and Principst subjects of Research } \\
\text { during tenurc of Scholarship }\end{array}$ & $\begin{array}{l}\text { Degrees and other dis- } \\
\text { tinctions obtained } \\
\text { since appointmeent to } \\
\text { Scholarship }\end{array}$ & $\begin{array}{l}\text { Particulars of Scholar's subseqnent career } \\
\text { is far as ascertaiucd }\end{array}$ \\
\hline $\begin{array}{l}\text { 70. Farmer, John Taylor, B.Sc. Cile. } \\
\text { Nominated by University College, } \\
\text { Liverpool (now University of } \\
\text { Liverpool) }\end{array}$ & $1895-7$ & $\begin{array}{l}\text { MacDonald Engineering Labora- } \\
\text { tory, Montreal }\end{array}$ & $\begin{array}{l}\text { Engincering.-Phcnomena of impact } \\
\text { and their application to water motors }\end{array}$ & $\begin{array}{l}\text { Ma.E. McGill } \\
\text { (1897), } \\
\text { M.Sc. Liverpool } \\
\quad(1901)\end{array}$ & $\begin{array}{l}\text { 1897, Entered sorvice of Canadian } \\
\text { Government as Assistant Examiner } \\
\text { in Patcnt Office. 1899, in tho } \\
\text { employ of Crosby Steam Gaugc \& } \\
\text { Valvo Co., Boston ; Ball \& Wood } \\
\text { Co., Elizabeth, N.Y.; Watts-Camp- } \\
\text { bell Co., Newark, N.Y. } 1901, \\
\text { Assistant Engineer to the Green } \\
\text { Fuel Economizer Co., N.Y. 1905, } \\
\text { opened office in Montreal as Canadian } \\
\text { representative of Green Fuel Econo- } \\
\text { mincer Co., and varions Britisls firms. }\end{array}$ \\
\hline $\begin{array}{l}\text { 71. Aston, Emily, B.Sc. } \\
\text { Nominated by University College, } \\
\text { London }\end{array}$ & $189 \pi-\pi$ & $\begin{array}{l}\text { University Collegre, London, and } \\
\text { University of Cieneva }\end{array}$ & $\begin{array}{l}\text { Chemistry.-Pyridine compounds. In- } \\
\text { fluence of temperature on the } \\
\text { rotatory powcr of liquids, sto. }\end{array}$ & - & $\begin{array}{l}\text { Discontinued research a few years after } \\
\text { expiration of scholarstip. }\end{array}$ \\
\hline $\begin{array}{l}\text { 72. Moorby, William Henry, B.Sc. } \\
\text { Nominated by Owens College, } \\
\text { Hanchcster (now Victorin Uni- } \\
\text { versity of Manchester) }\end{array}$ & $1895-6$ & Owens College, Manchester & $\begin{array}{l}\text { Engineering.-Tlis mechanical oquiva- } \\
\text { lent of heat }\end{array}$ & $\begin{array}{l}\text { M. Sc. Victoria } \\
\quad(\text { I } 897), \\
\text { A.MI. Inst.C.E. } \\
\quad(1897)\end{array}$ & $\begin{array}{l}\text { 1896-7, Demonstrator in Engineering. } \\
\text { Owens College, Manchester. Assist:ult } \\
\text { Civil Engineer in H.M. Naval } \\
\text { Establislmments: at Devonport Dock- } \\
\text { yard, 1897-1900; at Jamaica Yard, } \\
1900 \text {. Civil Engineer at Dovonport } \\
\text { Dockyard, 1903; at Gibraltar Dock- } \\
\text { yard, 1905; at Admiralty, } 1910 \text {. }\end{array}$ \\
\hline $\begin{array}{l}\text { 73. Mellanby, Alexander Lawson, A.Sc. } \\
\text { Nominated by Durham Collcgo of } \\
\text { Science (now Armstrong Col- } \\
\text { lege, Newcastle-upon-Tyne) }\end{array}$ & $1895-7$ & $\begin{array}{l}\text { MacDonald Engineering Labora- } \\
\text { tories, Montreal, and Durham } \\
\text { College of Scienco }\end{array}$ & $\begin{array}{l}\text { Mechanical Engincering. - Relative } \\
\text { officiencies of multiple cxpansion } \\
\text { engines }\end{array}$ & $\begin{array}{l}\text { B.Sc. Durham } \\
\text { (1896), } \\
\text { M.Sc. Durham } \\
\text { (1899), } \\
\text { M.Sc. McGill } \\
\text { (1899), } \\
\text { D.Sc. Durham } \\
\text { (1905) }\end{array}$ & $\begin{array}{l}\text { 1897-8, Chief Technical Assistant, } \\
\text { Messirs. Richardsons, Westgarth, } \\
\text { Hartlepool. 1898-9, Chief Lecturer } \\
\text { in Engineering, Battersea Poly- } \\
\text { technic. 1899-1905, Lecturer in } \\
\text { Engineering, Manchester School of } \\
\text { Tcchnology. Since September 1905 } \\
\text { Professor of Engineering, Glasgow } \\
\text { and West of Scotland 'Technical Col- } \\
\text { lege. }\end{array}$ \\
\hline
\end{tabular}


74. Foilmann, Martin Ernest, B.Sc. . Nominated by University College, Nottingham

75. Hanna, William, M.A. Nominated by Queen's College, Belfast (now Queen's University of Bclfast)

76. King, Robert Owen, B.Sc. Nominated by MeGill University, Montreal

77. Walker, Thomas Leonard, M.A. . Nominated by Queen's University, Kingston, Ontario
Chemistry.-Investigation of properties and reactions of metabrom- $\beta$. phenyl-hydroxylamine

$1895-7$

Laboratorics of Royal Colleges of Physicians and Surgeons, Hygiene and Bacteriology, Berlin

$1895-8$

McGill College and Harvard Col. lege

University of Leipzio

Biology.-Researches in pathology and bactcriology as connceted with discases of cattle
Ph.D. Basle

as becn engaged in the research laboratories and works of various coal tar colour manufacturors, and is now Consulting Chomist to the Stcam Elcctric Lamp Co., Ltd., continuing his rescarch work, and carrying on a gencral consulting and analytical practice.

I. B., B.Ch. (1895), Diploma in Public of Cambridge (1S98)
Elcctricity and Magnetism.-Thermal conductivity of motals. Experiments on the absolute mcasurement of the Thomson effect in copper. Absolute measurement of the E.M.F. of the Clark cell, using a W meter and Callendar methods
M.Sc. McGill (1898)

Ph.D. Lcipzig
898-1901, in India as Medical Officcl for Plamuc Duty in Madras, and as Bacteriologist in the Govcrument Plaguc Laboratory in Bombay. Since 1001 Assistant Medical Officcr of Health for the City and Port of Liverol and Lccturer on Bectoriology and Yrot and Food Inspection lo f tiver Mcdical Inspector of Alicns at spector, Board of Agriculture, under Diseascs of Animals Act.

Manager, King Construction Company, North Tonawanda, Now York. Designcd improvements in salvago methods and acted as consulting cngineer for various salvago operations. Spccialising in desion of horticultural buildings which are now in usc in England, France and Amcrica.

1897-190I, Assistant Supcrintendent, Gcological Survey of India, Calcutta. Sinco 1901 Professor of Mineralogy and Pctrography, University of 'I'oronto.
Mineralogy.-Studies of the Sudbury (Ontario) ore deposits 
LIST OF SCIENCE RESEARCH SCHOLARS APPOINTED BECWEEN THE YEARS I891 AND 1910-continued.

\begin{tabular}{|c|c|c|c|c|c|}
\hline Name of Scliolar & $\begin{array}{l}\text { Years of tenure } \\
\text { of Scholarsbip }\end{array}$ & Places of study during Seholarship & $\begin{array}{l}\text { Branch of Science } \\
\text { :tul Prineipal subjects of Researels } \\
\text { thring temure of Scholarship }\end{array}$ & $\begin{array}{l}\text { Degrees and other dis- } \\
\text { tinctions obtained } \\
\text { since appointment to } \\
\text { Soloolarship }\end{array}$ & $\begin{array}{l}\text { Particulars of Seholar's subsequent career } \\
\text { as far is ascertained }\end{array}$ \\
\hline $\begin{array}{l}\text { i3. Futherford, Ernest, M.A., B.So. } \\
\text { Nominated by University of Now } \\
\text { Zealand }\end{array}$ & $189.5-8$ & Cavendish Laboratory & $\begin{array}{l}\text { Electrieity and Magnetism.- Magnetic } \\
\text { viseosity. A magnetie detector of } \\
\text { electrical waves and some of its } \\
\text { applications. Passage of eleetrieity } \\
\text { through gases. Volocity and rate } \\
\text { of reeombination of ions and gases } \\
\text { exposed to Röntgen rays. Elcctri- } \\
\text { fieation of gases exposed to Röntgen } \\
\text { rays. Conduction in gases caused } \\
\text { by uranium radiation. Dischargo of } \\
\text { eleetrification by ultra-violet light }\end{array}$ & $\begin{array}{l}\text { B.A. Cambridge, } \\
\text { Coutts-Trotter } \\
\text { Studentship (1897) } \\
\text { D.Sc. New Zealand } \\
\text { (1899), } \\
\text { F.R.S. (1903). } \\
\text { Hon. LL.D. } \\
\text { Me(rill, Wisconsin, } \\
\text { Philadellhia, } \\
\text { Hon. I'h.D. } \\
\text { Giessen, } \\
\text { Hon. D.Sc. } \\
\text { Dublin }\end{array}$ & $\begin{array}{l}\text { 1898-1907, Maedonald Professor of } \\
\text { Physies, MeGill University. 1903, } \\
\text { eleeted Fcllow of Royal Soeiety. De- } \\
\text { livered, in 1904, Bakerian Leeture, } \\
\text { Royal Soeiety, and awarded the } \\
\text { Rumford Medal. Since } 1907 \text { Lang- } \\
\text { worthy Professor and Director of the } \\
\text { Physical Laboratories, Victoria Uni- } \\
\text { rersity of Maneliester. Awarded } \\
\text { Bressa Prize in } 1907 \text {, Nobel l'rize for } \\
\text { Chemistry 1908, and Barnard Medsl } \\
\text { 1910. Author of "Radio-netivity" } \\
\text { (2 editions), and "Radio-active } \\
\text { Transformations." }\end{array}$ \\
\hline $\begin{array}{l}\text { 79. Watt, John Alexander, M.A., B.Sc. } \\
\text { Nominated by University of } \\
\text { Sydney }\end{array}$ & $1895-6$ & $\begin{array}{l}\text { Royal College of Science, Lon. } \\
\text { don, and Mining Academy, } \\
\text { Freiburg }\end{array}$ & Mineralogy.-Genesis of ore deposits. & - & $\begin{array}{l}\text { Formerly engaged in the Gcological } \\
\text { Survey of New South Wales; now } \\
\text { practising medicine in Now South } \\
\text { Wales. }\end{array}$ \\
\hline $\begin{array}{l}\text { 80. Henderson, William Craig, M.A., } \\
\text { B.Se. } \\
\text { Nominated by University of Glas- } \\
\text { gow }\end{array}$ & $\begin{array}{l}1896-8 \\
\text { (Eighteen } \\
\text { months) }\end{array}$ & Cavendislı Laboratory & $\begin{array}{l}\text { Physics. - The motion of the rther in } \\
\text { an electro - magnetie field. The } \\
\text { mutual effeet of evaporation and } \\
\text { oleetrification of liquids }\end{array}$ & $\begin{array}{l}\text { B.A. Cambridgo } \\
(1900) \\
\text { D. Sc. Glasgow } \\
(1902)\end{array}$ & $\begin{array}{l}\text { 1898-1900, Private Secretary and As- } \\
\text { sistant to Lord Kelvin. In } 1900 \\
\text { ealled to the Bar. }\end{array}$ \\
\hline $\begin{array}{l}\text { S1. Ogg, Alezander, M.A., B.Sc. } \\
\text { Nominated by University of Aber- } \\
\text { deen }\end{array}$ & $1896-8$ & University of Göttingen . & $\begin{array}{l}\text { Physieal Chemistry.-Chemical equili- } \\
\text { brium and electromotivo forees of } \\
\text { amalgams }\end{array}$ & $\begin{array}{l}\text { Ph.D. Göttingen } \\
\text { (1898), } \\
\text { Fellow of Royal } \\
\text { Society of South } \\
\text { Africa }\end{array}$ & $\begin{array}{l}\text { 1900-1, Assistant Professor of Physics, } \\
\text { Aberdeen Univcrsity. 1901-5, As- } \\
\text { sistant Mraster, Royal Naval En- } \\
\text { gineering College, Devonport. Since } \\
\text { 1905 Professor of Physics and Ap- } \\
\text { plied Mathematics, Rhodes Uni- } \\
\text { versity College, Grahamstown, South } \\
\text { Africa. Exaniner in the University } \\
\text { of the Cape of Good Hope. }\end{array}$ \\
\hline
\end{tabular}


82. Price, Thomas Slater, B.Se. Nominated by Mason College, Birmingham (now University of Birmingham)

83. Fortey, Emily Comber, B.Se.. Nominated by University College, Bristol (now University of Bristol)

84. Dawann, Harry Medforth, B.Se. . Nominated by Yorkshire College, Leeds (now University of Leeds)

85. Annett, Henry Edward, M.B., D.P.H.

Nominated by University College, Liverpool (now University of Liverpool)
Loipzig and

sical Chomistry.-Optically netive anylic salts of glyceric, diacetylacids. Catalytic reactions. The tompcrature co-effieicnt of cstersaponification

Royal Vetorinary College, London, and Royal Institute for Infectious Diseases, Berlin

Ph.D. Leipzig

D.Sc. Sc. Birminghan

University College, Bristol year) and Owens College, Manchester ( $1 \frac{1}{2}$ yoars)

Universities of Berlin, Leipzig and Giessen

Chemistry.-The isolation of hexamothyleno by fractional distillation from American and (ialician petroof some of its derivatives

Physieal Chemistry.-Lowering of the by the addition of foreign substances. Racemic transformation of ammonium bimalate. Influence of pressure on the formation of oceanic salt deposits. Electrical conductivity and luminosity of tlames containing vaporised salts

Comparative Pathology and Bacteriology. - Symptomatic anthrax malignant cedema; bradsot of sheep braxy loum, togothor with the preparation melting point of magnesium chloride (Is!s), (1900), (1900), I.C. $(1905)$

1900-1, Assistant Leeturer and Demonstrator in Chcmistry, Univorgity College, Sheffield. 1901-3, Senior Leeturcr in Chemistry, University of Bing ing of tho Chemical Department at the M.inipal seche nuingham. Also, sinee 1907, Nxamincr in Physical chomistry tor the Final Examination of tho Instituto of Chemistry, and sinee 1909 Assistant Lxamincr in Chemistry for London University Hatriculation. 1909-191 Chairman of the Birningham Soetion of the Socicty of Chemieal Industry. Chcmistry." Joint author of "A Course of Practical Organic Chemistry."

1898-1902, published several papers in conjunction with Dr. Sydney Young, TP. R. in the Journal of the Chemical Society. Since 1902 has done no reSociety. Since

Ph.D. Giesson, D.Sc. Lceds

MI.D. Vietoria (1899)

1899. Demonstrator, and 1900, As sistant Lecturer and Demonstrator in Chomistry, Yorkshire College, Leeds. Sinco 190j Leeturcr on Phys cal Chemistry, University of Leeds. Teturer in Chemistry, University ledited Arrhenius' "Theories of

Since 1904 Superintendent of tho Liverpool Institute of Comparativo Pathology, and, sinec 1907, Professor of Comparative Pathology, Univer. sity of Liverpool. 
LIST UF SCIENCE RESEARCH SCHOLARS APPOINTED BETWEEN THE YEARS 1891 AND 1910-continued.

\begin{tabular}{|c|c|c|c|c|}
\hline Name of Scholar & $\begin{array}{l}\text { Years of tenure of } \\
\text { Scholarship }\end{array}$ & Places of study during Scholarship & $\begin{array}{l}\text { Branch of Science } \\
\text { and Princinal subjects of Research } \\
\text { during tenurc of Scholarship }\end{array}$ & $\begin{array}{l}\text { Degrees and otber dis- } \\
\text { tinctions obtained } \\
\text { since appointment to } \\
\text { Scholarship }\end{array}$ \\
\hline $\begin{array}{l}\text { 86. Petavel, Joseph Ernest } \\
\text { Nominated by University College, } \\
\text { London }\end{array}$ & $1896-9$ & $\begin{array}{l}\text { Royal Institution Davy-Fara- } \\
\text { day Researeh Laboratory, } \\
\text { London }\end{array}$ & $\begin{array}{l}\text { Engineering and Eleetrieal Physies.- } \\
\text { The heat dissipated by a platinum } \\
\text { surface at high temperatures. On } \\
\text { some standards of light. Assisted } \\
\text { Professors Dewar and Fleming in } \\
\text { various researehes on the properties } \\
\text { of matter at low temperatures }\end{array}$ & $\begin{array}{l}\text { M.Se. Vietoria, } \\
\text { D.Se. Victoria, } \\
\text { A.M.Inst.C.E., } \\
\text { A.M.Inst.E.E., } \\
\text { W.R.S., } \\
\text { F.R.Met.Soe. }\end{array}$ \\
\hline $\begin{array}{l}\text { 87. Heinke, John Leithart, B.Sc. } \\
\text { Nominated by Owens College, } \\
\text { Manchester (now Victoria } \\
\text { University of Hanchester) }\end{array}$ & $1896-8$ & $\begin{array}{l}\text { Owens College, Manehester ( } 1 \\
\text { year); University of Tübin- } \\
\text { gen (1 } 13 \text { years) }\end{array}$ & $\begin{array}{l}\text { Organie Chemistry.-Synthesis of iso- } \\
\text { propylglutarie aeid. Aetion of diazo- } \\
\text { methan on various nitro bodies }\end{array}$ & $\begin{array}{l}\text { D.Se. Tübingen } \\
\text { (1898) } \\
\text { M.Se. Vietoria }\end{array}$ \\
\hline $\begin{array}{l}\text { 88. Smythe, John Armstrong, B.Sc. } \\
\text { Nominated by Durham College of } \\
\text { Scienee (now Armstrong Col- } \\
\text { lege, Neweastle-upon-Tyne) }\end{array}$ & $1896-8$ & University of Göttingen . & $\begin{array}{l}\text { Organie Chemistry.-The proximate } \\
\text { eonstituents of eoal. Derivatives of } \\
\text { turpentine }\end{array}$ & $\begin{array}{l}\text { Ph.D. Göttingen } \\
\text { (1898), } \\
\text { M.Se. Durham } \\
\text { (1902), } \\
\text { D.Se. Durham } \\
\text { (1908) }\end{array}$ \\
\hline $\begin{array}{l}\text { 89. Bryan, George Blackford, B.Sc. } \\
\text { Nominated by University College, } \\
\text { Nottingham }\end{array}$ & $1898-9$ & Cavendish Laboratory & $\begin{array}{l}\text { Electrieity.- Conduetivity of liquids in } \\
\text { thin layers. Influenee of a metal on } \\
\text { the nature of a surfaee of another } \\
\text { metal plaeed elose to it. Deter- } \\
\text { mination of the eontaet potential } \\
\text { differenees between a metal and } \\
\text { solutions of salts of the same metal }\end{array}$ & $\begin{array}{l}\text { B.A. Cambridge } \\
\text { (1898), } \\
\text { D.Se. London } \\
\text { (1899) }\end{array}$ \\
\hline
\end{tabular}
Particulars of Scholar's subsequent career
as far as nscertained

1900-3, John Harling Fellow of Owens College, Manehester. 1904, Seientifie Manager of the Low 'Iemperatur Exhibit of the British Royal Commission for the St. Louis Exhibition. 1907, Fellow of the Royal Soeiety. 1908, Beyer Professor of Engineering and Direetor of the Whitworth Laboratory, Vietoria University of Manehester. Member of the Advisory Committee for the Departmental Committee on Humidity and Ventilation in Cottonweaving Sheds, the British Assoeiation Committee on Gas Explosions, and the British Assoeiation Committee on Investigation of the Upper Atmosphere.

1898-1903, Chemist, Badisehe Anilin und Soda Fabrik. Sinee 19113 Chemieal Manager, Dyehouse Department, Burgess, Ledward \& Co., Walkden, Manehestcr.

Sinee 1898 Lecturer in Chemistry, Armstrong College, Newcastle-uponTyne.

1899, Leeturer in Physies at the Royal Naval College, Devonport, and in 1908 Senior Assistant Mastar. 1910 Instruetor in Physies at the Royal Naval College, Greenwieh. 
90. Richardson, Spencer William, B.Sc Nominated by University College of Wales, Aberystwyth

91. Williams, David, B.Se. Nominated by University College of North Wales, Bangor

2. Henry, John, M.A., B.Eng. Nominated by Quecn's Collcge, Galway (now University Colloge, Galway.)

93. Scott, Arthur Melville, B.A. Nominated by University of I'oronto trative power of the radiation emitting from the glow of an electrodeless discharge. The magnetic propertics of rings composed of alloys of iron and aluminium. Some changes in the magnotic condition of an alloy of ncarly pure iron and aluminium

University of Berlin . . Enginecring-Hystoresis in iron in slow and rapid cycles

Cavendish Laboratory . - Electricity.-The motion of the æther in a magnetic field. The effect of ultra-violet light on the conductivity of iodine vapour. The deflection by magnctic forces of the clectric discharge througl gases of the capillary electrometer. Polarisation capacity
M.A. Cambridge, D.Sc. London Principal of Hartley University College,
Southampton.

B.A. Cambridgo (1899),

Junior Fellowship in Physics in Royal University of Ireland (1899)

Ph.D. Göttingen
1899, Acting Professor of Mathematics and Scicnce, Gill College, Somerset East, Capc Colony. 1900, Mastcr, Gill College High School. Acting Professor of Mathematics, Vietoria Collcge, Stellenbosch, Cape Colony. 1901-2, Science Master, Kondebosch High School. 1902-3, Assistant Surveyor, Forcst Department, Cape Colony. 1904, appointed Cape Government Land Surveyor. Since 190 + Lecturer in Pure Mathematics at the Phode University College, Grahamstown.

$1898-1900$, Lccturer in Plyysics, Qucen's Collego, Galway. 1900-1, Studied electrical engincering, Central 'T'echnical College, London. 1901-2, Engaged in practical work at Central Station (Electric), Belfast. 1902Phy Phys and Elcosical Enging

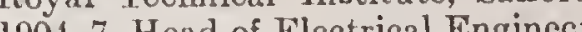
$1904-7$, Head of Eloctrical Engincering Department, Auckland Technical College, Ncw Zealand. Sinco 1907 Science Teacher, High Sehool Dawson, Y.T., Canada.

1898, Instructor of Physics, University of Toronto. 1899, Professor of Plyysies and Electrical Engineering, University of New Brunswick. 1906, Supcrintendent of Sehools under the Calrary Public School Board, Calgary, Alberta, Canada. 
LIST OF SCIENCE RESEARCH SCHOLARS APPOINTED BETWEEN THE YEARS 1891 AND 1910-continued.

\begin{tabular}{|c|c|c|c|c|c|}
\hline Name of Scholar & $\begin{array}{l}\text { Years of tenure } \\
\text { of Scholarship }\end{array}$ & Places of study during Scholarship & $\begin{array}{l}\text { Branch of Science } \\
\text { aml Principal snbjects of Researel } \\
\text { dluring tenure of Scholarship }\end{array}$ & $\begin{array}{l}\text { Degrees and other dis- } \\
\text { tinetions obtained } \\
\text { since appointment to } \\
\text { Sebolarship }\end{array}$ & $\begin{array}{l}\text { Particulars of Scholar's subsequent eareer } \\
\text { as fur as ascertnined }\end{array}$ \\
\hline $\begin{array}{l}\text { 94. McIntosh, Douglas, B.Sc. U. } \\
\text { Nominated by Dalhousie Univer- } \\
\text { sity, Halifax, Nova Scotia }\end{array}$ & $1896-9$ & $\begin{array}{l}\text { Comell University (2 ycars); } \\
\text { University of Imiprig (1 year) }\end{array}$ & $\begin{array}{l}\text { Physical Chemistry. - Relations be- } \\
\text { tweon solubility and freczing point } \\
\text { in mixturcs containing threc conn- } \\
\text { ponents. Elcetromotive force of } \\
\text { gas cells }\end{array}$ & D.Se. & $\begin{array}{l}\text { Appointed Demonstrator in Chemistry. } \\
\text { McGill University, Montrual, in } \\
\text { I901; Lecturer in 1904; Assistant } \\
\text { Professor in 1907; and Associate } \\
\text { Professor in 1908. }\end{array}$ \\
\hline $\begin{array}{l}\text { 95. Frskine, John Angus, M.A. } \\
\text { Nominated by University of New } \\
\text { Zealand }\end{array}$ & $1890-8$ & $\begin{array}{l}\text { Universities of Borlin and Leip- } \\
\text { zig }\end{array}$ & $\begin{array}{l}\text { Electricity.-The screening of mag- } \\
\text { notic and of electromotive force in } \\
\text { the ficlds produccd by Loyden jar } \\
\text { discharges. Determinations of di- } \\
\text { olectric constants. 'Llhe resistanco } \\
\text { of olectrolytes for' rapilly alternating } \\
\text { currents }\end{array}$ & - & $\begin{array}{l}\text { Eleotrioal Engineer with the Sulphide } \\
\text { Corporation, Broken Hill, New South } \\
\text { Wales. }\end{array}$ \\
\hline $\begin{array}{l}\text { 96. Smith, Longfiold, B.Sc. } \\
\text { Nominated by University of Edin- } \\
\text { burgh }\end{array}$ & $1897-9$ & $\begin{array}{l}\text { Universitics of Leipzig, Paris, } \\
\text { and Edinburgh }\end{array}$ & $\begin{array}{l}\text { Organic Chemistry. - Unsaturated } \\
\text { cycle-kctones. Componnds of hydra- } \\
\text { zone and semi-carbazone }\end{array}$ & Ph.D. Leipzig & $\begin{array}{l}\text { 1899, appointed Privatc Assistant to } \\
\text { Professor D'Albuquerque, Island } \\
\text { Professor of Chcmistry and Agricul- } \\
\text { tural Scicnce, Barbados. 1901, ap- } \\
\text { pointed by Imperial Government } \\
\text { I.ceturer in Agricultural Scicnce } \\
\text { at Barbados. 190t, appointed } \\
\text { Assistant Chemlst for Sugar Cane } \\
\text { Research Experiments. 1909, scr- } \\
\text { vices transferred from Imperial } \\
\text { Government to Local Government of } \\
\text { Barbados as Lceturer in Natural and } \\
\text { Agricultural Scicnecs. }\end{array}$ \\
\hline $\begin{array}{l}\text { 97. Muir. James, B.Sc. } \\
\text { Nominated by University of Glas- } \\
\text { gow }\end{array}$ & $1897-1900$ & $\begin{array}{l}\text { Engineering Laboratory, Cam- } \\
\text { bridge }\end{array}$ & $\begin{array}{l}\text { Engineering.- The recovery of iron } \\
\text { from overstrain. The effect of tem- } \\
\text { pering iron hardened by orerstrain }\end{array}$ & $\begin{array}{l}\text { B.A. Cambridge } \\
\text { (1899), } \\
\text { D.Sc. Glasgow } \\
\text { (1902), } \\
\text { M.A. Cambridgo } \\
(190+)\end{array}$ & $\begin{array}{l}\text { 1902-6, Lecturer and Assistant at the } \\
\text { University of Glasgow. Since } 1906 \\
\text { Professor of Natural Philosophy in } \\
\text { Glasgow and West of Scotland } \\
\text { T'cehnical College. }\end{array}$ \\
\hline $\begin{array}{l}\text { 98. Kyle, Harry McDonald, M.A., B.Sc. } \\
\text { Nominated by University of St. } \\
\text { Andrews }\end{array}$ & $1897-1900$ & $\begin{array}{l}\text { Gatty Marine Laboratory, St. } \\
\text { Andrews; Laboratoire Arago, } \\
\text { Banyuls-sur-Mer; Königl. } \\
\text { Biolog. Anstalt, Heligoland; } \\
\text { Zoological Stations, Helder } \\
\text { and Naples }\end{array}$ & $\begin{array}{l}\text { Zoology-- Natural history of the her- } \\
\text { ring and plaice. Classification of the } \\
\text { Hat fishes }\end{array}$ & $\begin{array}{l}\text { D.Se. St. Andrews } \\
(1901)\end{array}$ & $\begin{array}{l}\text { 1901-3, Assistant Naturalist of the } \\
\text { Marine Biological Association, Ply- } \\
\text { mouth. Since 1903, Assistant Secre- } \\
\text { tary Bureau du Conseil International } \\
\text { pour l'Exploration de la Mor, Copen- } \\
\text { hagon. }\end{array}$ \\
\hline
\end{tabular}


99. Kay, Sydney A., B.Se. . Nominated by University College, Dinndee

100. Shakespear, Gilbert Arden, B.A., B.Sc. Lond. mingham (now Uuiversity of Birmingham)

101. Sprankling, Charles Henry Graham, B.Sc Iond.

Nominated by University Colloge, Bristol (now University of Bristol)

102. Wilson, Harold Albert, B.Se. Nominated by Yorkshiro College, Leeds (now University of Leeds)

103. Caspari, William Augustus, B.Se Nominated by University College, Liverpool (now University of Liverpool)

104. Williams, Perey, B.Se. . Nominaled by University College, London
Nominated by Mason College, Bir-
Högskola, Stockholm, and Unirersity of Leipzig

$1897-9$

Cavendish Laboratory

Universities of Jcna and Göttingen

\section{Owens College, Manchester}

\section{Cavendish Laboratory and Uni-} versity of Berlin
Physieal Chemistry.-Equilibrium betwcen sulphurie acid and sulphate in solution. Various allotropic modifications of metallic silver

Physics.-Application of an interferenee method to the investigation of Young's modulus for nires and its relation to changes of tculperature and magnotisation

Chemistry. $-\beta$ aldchydo-propionic acid and $\beta$ aldehydo-isobutyric aeid; the alkyl-substituted succinic neids, \&e.

D.Sc. St. Andrews (1902).

F.C.S. (1905)

B.A. Cambriclge

lectricity.-The influenec of dissolved substances and of elcctrification on the reformation of elouds. The eleetrie conduetivity of salt vapours. The volocity of solidifiention and viscosity of supereooled liquids. 'The variation of the cleetrie intensity and eonduetivity along the electric discharge in rarefied gases. 'T'he formation of syngenite

Organic Chemistry. - The tantomerism in isocarbopyrotritaric ester and its derivatives. the reversibility of the oxyhydrogen electrolysis

Eeole de Pharmacie, Paris, and Laboratory of Professo van't Hoff, Berlin

I.A. Cambridge, M.Sc. Victoria F.R.S. (1906)

Chemistry.-Preparation and properties of borides of ealeium, strontium, and barium, and other rescarches in
1900-1909, Assistant and Leeturer in Chemistry, United College, St. Andrews University. Now Assistant in Chemistry, Edinburgh University.

Lecturer in Physies and Special Teeturcr on Experimental Physies, University of Birmingham. conneetion with Moissan's electric furnaco. Investigation of the Stassfurt minerals
S.Sc. Bristol

Since Scptember 1908 Senior Scienec Master at the Bury Gramuar School. lormerly held various teaching posts and spent cightcen months in Antigur as Assistant Government Aualyst to the Leeward Islands.

1901-7, Fellow of Trinity Collego, of the Royal Society. 1905-9, Professor of Physics. King's College. London, and Lxternal Examiner in Physies to the Universitics of London, Birmingham and Lecds. Since 1909 Professor of Physies, McGill University, Montreal. Diseovered electric effect of rotating dielcetries in a magnetic field.

Ph.D. Jena

nugaged in rescarch work for Sir John Jurray, Ediuburch : formerly ReSeareh C'bernint to : foumtroc \& Co. Istr.. York.

Formerly Head Chemist to the British Uralite Co., Ltcl. Now Manager of a tannin extract factory at Sockadana. llest Borneo. Cambridge. Eleeted in 1906 Follow 
LIST OF SCIENCE RESEARCH SCHOLARS APPOINTLD BLTWEEN THE YEARS 1891 AND 1910-continued.

\begin{tabular}{|c|c|c|c|c|c|}
\hline Name of Scholar & $\begin{array}{l}\text { Years of tenure } \\
\text { of Scholarship }\end{array}$ & Places of study during Scholarship & $\begin{array}{l}\text { Branch of Scienec } \\
\text { anu Principal strbjects of Research } \\
\text { during tenurc of Scholarship) }\end{array}$ & $\begin{array}{l}\text { Digrees and other dis- } \\
\text { tinctions obtained } \\
\text { since appointment to } \\
\text { Sclolarship }\end{array}$ & $\begin{array}{c}\text { Particulars of Scholar's subsenucnt earcer } \\
\text { it far at nscertnined }\end{array}$ \\
\hline $\begin{array}{l}\text { 105. (irindley, John Henry, B.Se. } \\
\text { Nominuted by Owens College, } \\
\text { Mrnnehester ' (now Victoria Uni- } \\
\text { versity of Manelester) }\end{array}$ & $1597-9$ & Owens College $\cdot{ }^{-}$ & $\begin{array}{l}\text { Engineering.-Conneetion between the } \\
\text { saturated and superheated eonditions } \\
\text { of stean }\end{array}$ & $\begin{array}{c}\text { M.Se. Vietoria } \\
\text { (1St)9), } \\
\text { D.Se. Vietoria } \\
\text { (1.902). } \\
\text { M.1.Mrect.E. (1906) }\end{array}$ & $\begin{array}{l}\text { 1899, Demonstrator in Lingineering, } \\
\text { (Owens College, Manchester. 1902, } \\
\text { Ifoad of Engineering Department, } \\
\text { Hudderstield T'ochuieal College. 1904, } \\
\text { Lecturer in Engineering, and. 1905, } \\
\text { in Applied Meehanics. Criversity } \\
\text { of Liverpool. Sineo } 1907 \text { Prineipal } \\
\text { of the School of Engincering, Gizeh, } \\
\text { Egypt. }\end{array}$ \\
\hline $\begin{array}{l}\text { 106. Hallaway, Robert Railton, 13.Sc. } \\
\text { Nominaled by Durham Collego of } \\
\text { Scienee (now Armstrong Col- } \\
\text { lege, Neweastle-upon-'Tyne) }\end{array}$ & $1897-9$ & $\begin{array}{l}\text { Universities of Bom and Heidel- } \\
\text { berg }\end{array}$ & $\begin{array}{l}\text { Organie Chemistry.-Proparation of } \\
\text { diiodacetyl-hydrazide, metanitro - } \\
\text { hippur-hydrazide and motanitro- } \\
\text { hippur-azide. and other derivatives. }\end{array}$ & $\begin{array}{l}\text { Ph.D. Heidelberg } \\
\text { (1901) }\end{array}$ & $\begin{array}{l}\text { 1901-1010, assisted his father as a } \\
\text { Chemist at Carlisle. Now in busi- } \\
\text { ness as a Pharmaceutieal Chemist in } \\
\text { Carlisle. }\end{array}$ \\
\hline $\begin{array}{l}\text { 107. Willows, Riehard Smill, B.Se. } \\
\text { Nominated by University College, } \\
\text { Nottingliam }\end{array}$ & $1897-9$ & Cavondish Laboratory & $\begin{array}{l}\text { Experinental Physics.-The variation } \\
\text { of resistaneo of certain analgams } \\
\text { with temperature. Tho distanee } \\
\text { between the strix in the positive } \\
\text { eolumn and other phenomena eon- } \\
\text { neoted with the dischiarge. 'lhe cause } \\
\text { of hardness in Röntgen ray bulbs }\end{array}$ & $\begin{array}{l}\text { M. A. Cambridge, } \\
\text { D.Se. London }\end{array}$ & $\begin{array}{l}\text { 1900-1, Leeturer in Physies at Battor- } \\
\text { sea Polytechnic. Sinee } 1902 \text { Head } \\
\text { of Mathematies and Physies Dopart- } \\
\text { mont, Sir Joh Cass Leehnical } \\
\text { Institute. Has acted as'Examiner in } \\
\text { Physics for the University of London. }\end{array}$ \\
\hline $\begin{array}{l}\text { 108. Clark, Emest } \\
\text { Nominuted by Firth College, } \\
\text { Shoffield (now University of } \\
\text { Sheffield) }\end{array}$ & $\begin{array}{l}1897-8 \\
\text { (Appointed for } \\
\text { one year) }\end{array}$ & $\begin{array}{l}\text { (Jwens College, Manchestor } \\
\text { (now Vietoria University of } \\
\text { Manchester) }\end{array}$ & $\begin{array}{l}\text { Organic Chemistry.-Synthosis of eom- } \\
\text { pounds relating to the camphorie } \\
\text { group }\end{array}$ & $\begin{array}{l}\text { B.Sc. London, } \\
\text { B.Se. Shefficld }\end{array}$ & $\begin{array}{l}\text { 1898-9, Rescareh Assistant, and sinco } \\
1899 \text { Assistant Iceturer in Chcmis. } \\
\text { try, Royal Teelnical Institute, } \\
\text { Salford. }\end{array}$ \\
\hline $\begin{array}{l}\text { 109. Dawson, Maria, B.Sc. } \\
\text { Nominuted by University College } \\
\text { of South Wales and Monmouth- } \\
\text { shire, Cardiff }\end{array}$ & $1897-1900$ & $\begin{array}{c}\text { Botanical Laboratory, Cam- } \\
\text { bridgo }\end{array}$ & $\begin{array}{l}\text { Botany--Nitragin. The organism of } \\
\text { tho nodules on the roots of legu- } \\
\text { minous plants }\end{array}$ & $\begin{array}{l}\text { D.Sc. London } \\
(1900) \text {. } \\
\text { 1).Sc. Wales } \\
(1900)\end{array}$ & 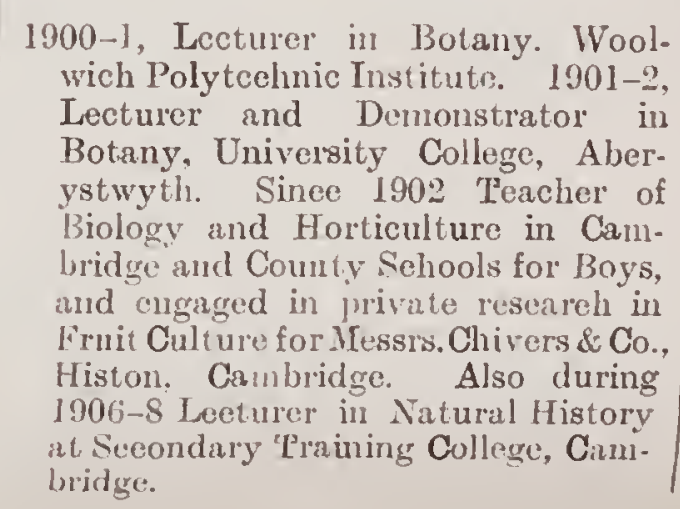 \\
\hline
\end{tabular}


110. Osborne, William Alexander, M.B. Nominated by Quccn's College, Belfast (now Queen's University of Bclfast)

111. Gill, James Lester Willis, B.App.Se. Nominaled by McGill University, Montreal

112. Pope Fredcrick John, M.A. Nominated by Qucen's University, Kingst on, Ontario

113. Strickland, 'Tom Pcrcival - Sydney

114. Roscnhain, Walter Nominated by University of MIelbourne

15. Bottomley, Jancs Frank, Ph.D. Nominated by University of Glas gow

116. Findlay, Alexander, M.A., B.Se. Nominuled by University of Aber dee
Physiological Chemistry.-Preparation of invertine, it propertios and clicmical

$1897-9$

McGill University and Harvard University

$1897-9$

Columbia University, New York

$1897-9$

McGill University, Montreal

$1897-1900$

Engineering Laboratory, Cam. bridge

Owens College, Manchester, and University College, London
Plysics-Mcasurcment of magnetic hysteresis and permeability

Analytical Chemistry.-Ontario magnotites, with particular referenco to those which are titaniferous

Hydraulics.- Various problems as to the flow of water in pipes; phenomena of jets, \&c.

Engineering. - Microscopic study of metals and their crystalline strueturc. 'The effects of strain and variation of temperature on such structure

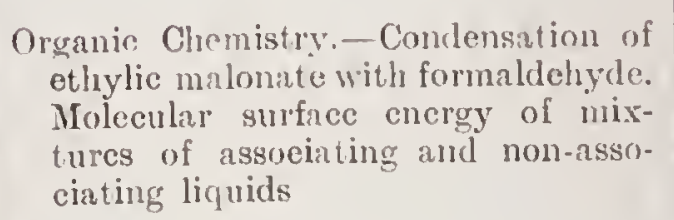

Organic Chemistry-Condensation of ethylic malonate with formaldehyde. Molecular surface cnergy of mixtures of assoeiating and non-associating liquids

D.Sc. Tübingen $(1899)$

M.Sc. McGill (190.4)

Pl.D. Columbia

UI.Sc. Sydnoy, A.A.T.E.E.

13.A. Cambridge, C.E. Mclbourne D.Sic. Melloournc$$
\text { (1) }
$$

University of Leipzig . . . Chemistry.-The theory of fractional precipitation
D. Sc. Aberdeen
(1902)
Since 1903 Professor of Physiology ?in the University of Mclbourne. Formerly Assistant Professor of Physiology, University Collegc, London.

Professor of Electrical Engineering, Sehool of Mines, Kingston, Ontario.

1899-1905, Economic Gcol igist with Ricketts \& Banks, New York; 1905-6, for Delamar Hines, New York Since 1906 with J. H. Ham. mond, New York.

Chicf Assistant Electrical Engineer, New South Wales Government Railways.

1900-6, Chicf Chemist and Scientific Adviser to Chance Bros. \& Co., Ltd., Glass and Lighthouso Works, Bir mingham. Since 1906 Superintendent of the Dcpartment of Mctallurgy and Metallurgical Chemistry in the National Plysical Laboratory. Past President of the Optieal Socicty of London. Awarded a Car'negic Rescarch Medal and Silver Medal of Royal Society of Arts. Published a book oll "Glass Manufaeture"

Appointed in 1901 on the staff of Herz and McLellan as Chemical Adviser, and his been engaged in working out in electric furnace process for the manufacture of fused silica on a large scale. 'This is now bcing worked commercially by the Thermal Syndicate, Ltd., of Wallsend-on-Tyne, and Mr. Bottomley holds the position of Manager of the Company.

Since 1902 Lecturer on Chemistry and Special Lecture on Physical Chemistry, University of Birmingham. 
LISI OF SCIENCE RESEARCH SCHOLARS APPUINIED BETWEEN THE YEARS 1891 AN1) 1910-continued.

\begin{tabular}{|c|c|c|c|c|c|}
\hline Name of Scholar & $\begin{array}{l}\text { Years of tenure } \\
\text { of Scholarship }\end{array}$ & Places of study duriug Scholarsinip & $\begin{array}{l}\text { Branch of Science } \\
\text { and Principal subjects of Research } \\
\text { during tenurc of Scholarship) }\end{array}$ & $\begin{array}{l}\text { Degrees and other dis- } \\
\text { tinctions obtained } \\
\text { sincc appointment to } \\
\text { Scliolarship }\end{array}$ & $\begin{array}{l}\text { Earticulars of Scholar"s sub-equent career } \\
\text { is far as ascertained }\end{array}$ \\
\hline $\begin{array}{l}\text { 117. Buller, A. H. Reginald, B.Se. } \\
\text { Nominated by Mason University } \\
\text { College, Birmingham (now } \\
\text { University of Birmingham) }\end{array}$ & $1898-1901$ & $\begin{array}{l}\text { University of Leipzig; \%oo- } \\
\text { logical Station. Naples; Uni- } \\
\text { versity of Mumiehs }\end{array}$ & $\begin{array}{l}\text { Physiological Botany - Tho proeess of } \\
\text { docay in plants; the physiology of } \\
\text { the spermatozon of ferns: the do- } \\
\text { struetion of the wood of Acer by } \\
\text { fungi, se. : chemotaxis and the fer- } \\
\text { tilisation of the eggs of animals }\end{array}$ & $\begin{array}{l}\text { Th.D. Loiprig } \\
\text { D.Sc. Birmingham } \\
\text { E.R.S.C. }\end{array}$ & $\begin{array}{l}\text { 1901-4. Lecturer on Botany, University } \\
\text { of Birminghim. IMit. Professor } \\
\text { of Botany, University of Manitoba, } \\
\text { Winnipeg., Author of " Resenrehes } \\
\text { on Fungi " (London, 1909.) }\end{array}$ \\
\hline $\begin{array}{l}\text { 118. Calvert, Harry Thornton, B.Se. . } \\
\text { Nominuted by Yorkshire College, } \\
\text { Leeds (now University of } \\
\text { Leeds) }\end{array}$ & $1898-1901$ & University of Leipris . & $\begin{array}{l}\text { I'lypical Chemistry.-'The eleetrolytie } \\
\text { oxidation of sulphurous acid. 'Thic } \\
\text { eonversion of yellow into red phos- } \\
\text { phortus. The ehemieal dynamies of } \\
\text { hydrogen peroxide }\end{array}$ & $\begin{array}{l}\text { Ph.D. Toipzig, } \\
\text { M.Ke. Loeds, } \\
\text { F.1.C. }\end{array}$ & $\begin{array}{l}\text { 1901. Demonstrator in Chemistry, York- } \\
\text { shire Cullege, Leeds. I!y0:2. Chemist to } \\
\text { lieckitt \& Sons, Ltd., liull. Since } \\
\text { January } 1903 \text {, Chinf Chemist to West } \\
\text { Riding Rivers Board, Wakefeld. }\end{array}$ \\
\hline $\begin{array}{l}\text { 119. Brown, Ernest, B.Sc. } \\
\text { Tominated by University Colloge, } \\
\text { Livorpool (now University of } \\
\text { Liverpool) }\end{array}$ & $\begin{array}{l}\text { 1898-1!900 } \\
\text { (Eighteen } \\
\text { montlis) }\end{array}$ & $\begin{array}{l}\text { Central Tcchnieal College, South } \\
\text { Iínsington }\end{array}$ & $\begin{array}{l}\text { Electrical Fingincering.-The riso of } \\
\text { tomperature of the tield eoils of } \\
\text { dynamos }\end{array}$ & $\begin{array}{l}\text { M.Se. Victoria } \\
(1900), \\
\text { II.ling. Liv'rpool } \\
(190 t)\end{array}$ & $\begin{array}{l}\text { Since } 1908 \text { Assoeiate Professor in } \\
\text { charge of Department of Applied } \\
\text { Mechinies, MeGill University, Mont- } \\
\text { real. Previously Assistant Pro- } \\
\text { fessor of Applied Mechanics. Award- } \\
\text { ed in I!ng the (ironshi Mledal of the } \\
\text { Canadian Society of Civil Engineers } \\
\text { for a paper on "Tests on reinforeed- } \\
\text { conerete beams." }\end{array}$ \\
\hline $\begin{array}{l}\text { 120. Filon, Louis Napoleon George, M.A. } \\
\text { Nominated by University College, } \\
\text { London }\end{array}$ & $\begin{array}{l}1898-9 \\
\text { and } \\
1900-2\end{array}$ & $\begin{array}{l}\text { King's College, Cambridge, and } \\
\text { Cavendish and Engineering } \\
\text { Laboratories, Cambridge }\end{array}$ & $\begin{array}{l}\text { Applied Mathematics. - Experimontal } \\
\text { and mathematical investigation of } \\
\text { problems eonnoeted with flexure, } \\
\text { torsion, and olastieity }\end{array}$ & $\begin{array}{l}\text { Fellow of Uni- } \\
\text { versity College, } \\
\text { London } \\
\text { (1898), } \\
\text { B.A. Cambridge, } \\
\text { (1901), } \\
\text { D.Su. London } \\
\text { (1902), } \\
\text { F.R.S. (1910) }\end{array}$ & 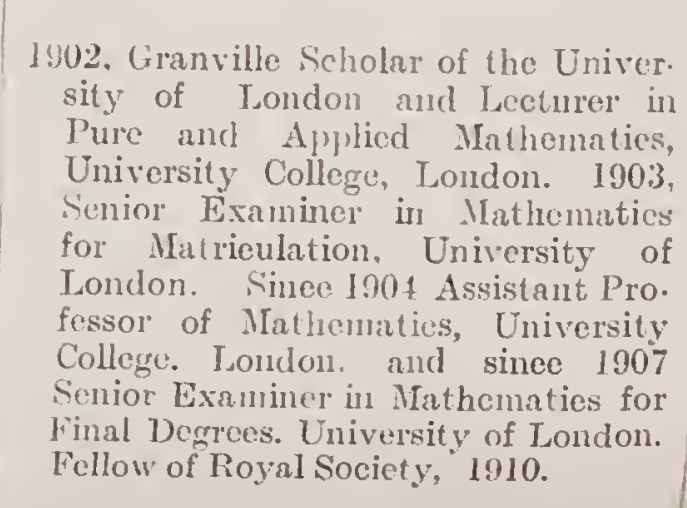 \\
\hline
\end{tabular}


121. Smith, James Henry, B.Se. . lominated by Owens Colloge Inanchester (now Victoria University of Nincliester)

122. Ashton, Arthur William, B.Se. . Vominated by Dnrham College of Science (now Arunstrong Col. lege, Newcastlc-upon-'I'yne)

123. Peake, Austin Henry . . Nominated by University College, Nottingham

124. Wills, Robert L., B.A.. A.R.C.Sc.I. Vominaled by Royal College of Seience for lreland

12\%. Butler, Edwin John, M.B. . . Nominnted by Queen's College. Cork (now University College, ('ork)

126 Ryan, Hugh, M.A. Fominaled by Quen's College, Galway (now University Col lege, Galway:)
Orens College, Mauchester permitted for spccial reasons)

Engineering.-Research on the fatigue

M.Sc. Victoria (1900).

D.Sc. Victoria (1903)

189S-1900 University College, London

$1898-1900$

Enginecring Laborntory. Cambridge

$1898-1901$

1898-1900

Botanical Jaboratories, Paris and Antibes: University of Freiburg; Royal Ciardens, sew

1898-9 University of Berlin. Chemistry--Amidoketones. The soealled syuthesis of eane sugar. Synthesis of glucosides

ML.Se. Durham

lectrieal Engineering.--The resistance of dielectrics and the effeet of alternating clccuro-molive force on the insulating

Enginecring.-The specifie hent of superheated steam (1901), $(1905)$, A.I.E.E.

Physies.-The effeet of temperature on the magnetic properties of tron and alloys of iron gamic botiny

Fellow and
1901-4, Head of Engincering Jepartment, Teehnieal College, Smiderland. since 1.105 l'rofussor of Mechanieal Engineering, Mmicipon Technieal Institute, Belfast. Holet a patent for a new type of fatigu toster.

A. Cambridge

II.A. Cambridge

Botany.-Plint pathology; 1ypto. Fellow of Limnean Sociely (1902) llember of Sorist

IIyeologicue de

France (1902) Examiner, Royal Eniversity of ireland (is:9?), D.Se. Royal Unirersity of Ireland

$$
\text { (1899), }
$$

1900-6. Assistant to Chicf Engineer at Helsby and Liverpool works of British Insulated \& Helsby Cables. Licl. 1006 Assistont Lecture Domenter in Flectrionl linginerDemonstator in Ely

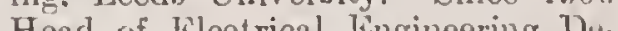
Hat of Bat

1900. Assistant Demonstrator in Fugineering, University of Cambrirlge: 1908. Senior University Demonstritor

Director of Further Education under fient Education Committee.

1901, Cryptogamic Potanist to the Inclian (iovermment. "incel 190 ti, Inperial Mycologist, Department of Arreulture in India. Also. 1910, Officiating Director, Agri eultural Researeh Institute. Pusa.

1899. Professor of Chemistry, Universit Cullege, and Mredical sichool. Dnblin. 1903 , elected member of the Royu Irish Academy. Since 190.) also Consulting Chemist of Apothrearines Hall for Ircland.

F.I.C. $(1904)$ 
LIST OF SCIENCE RESEARCH SCHOLARS APPOINTED BETWELN "HHE YEARS 1S91 AND 1910-continqed.

127. Smeaton, Willian Cabb, 13.A. . Nominated by University of Torouto

12S. Arohibald, Ebenezer Henry, M.Se. Vominated by Dalhousio Univor sity, Halifax

129. Mellor, Josoph William, B.Sc. Nominated by University of New Zoaland

130. Irvine, James Colquhoun, B.Se. Nominated by University of St. Andreivs

\begin{tabular}{|c|c|c|c|}
\hline $\begin{array}{l}\text { Years of tenure } \\
\text { of Scholarsbip }\end{array}$ & Places of study during Seholarsh & & $\begin{array}{l}\text { Brauch of Scieuce } \\
\text { and Primcipul subjects of Researoh } \\
\text { during tenure of Scholarship }\end{array}$ \\
\hline $1898-1900$ & University of Loipzig . & . & $\begin{array}{l}\text { Physieal Chemistry. - The translation } \\
\text { value of the silvor ion in a solution } \\
\text { of silver nitrate. Copper hydroxide } \\
\text { and eoppor oxide in thoir rolation- } \\
\text { ship to ammonia and annumium } \\
\text { salts }\end{array}$ \\
\hline $1898-1901$ & Harvard Univorsity . . & . & $\begin{array}{l}\text { Physical Chomistry. - The birth and } \\
\text { growth of erystals; the equilibrium } \\
\text { of mereury, mereurous ehloride, } \\
\text { and water solutions of other chlor- } \\
\text { ides; the atomic weight of ealcium }\end{array}$ \\
\hline $1898-1901$ & Owens College, Manchoster & . & $\begin{array}{l}\text { Chomistry.-The union of hydrogen } \\
\text { and ehlorine. Some a alliyl sub- } \\
\text { stitution products of glutario, adipie, } \\
\text { and pimelic acids }\end{array}$ \\
\hline $1899-1901$ & University of Loipzig. & . & $\begin{array}{l}\text { Organic Chemistry.-Synthesis of the } \\
\text { hydrocarbon phenanthreno. Pre- } \\
\text { paration and reaetions of salicyl- } \\
\text { aldehyde methyl ether. }\end{array}$ \\
\hline
\end{tabular}

\begin{tabular}{|}
$\begin{array}{c}\text { Degrees and other dis- } \\
\text { tiuctions obtained } \\
\text { sinee rappointunct to } \\
\text { Scholarship }\end{array}$ \\
\hline- \\
Ph.A. Harvard \\
(1900), \\
(1902) \\
Parvard \\
Ph.D. Leipzig \\
(1901), \\
D.St. Andrew's \\
(1903) \\
F.C.S. \\
D.Se. New Zealand \\
\end{tabular}

Particulars of Scholar's subsequent caree

1902-5. Instructor in Chomical Engincering: 1905-10. Instructor in Cencral Chemistry, 1910, Assistant Professor of Gencral and Plysical Chomistry, University of Michigan, U.S.A. Author of " Pext buok of Qualitative Analysis from the Standpoint of Mass Aetion \&e." Momber of German Chemical Soeiety, Ameri. can Chemical Society, American Association for the Advancement of Science, and National Gcographic Socicty.

1901-2, Assistant in Chemistry, Harvard College. 100"-4 Domonstrator in Chemistry. ITeGill Luiversity. 1904-6, Instructor in Chemistry: 1906, Assistant Profossor: 1009 Associate Professor ") Chemistry,

Syracuse University, New York.

Specialist in Clays l'ottery (Staffordshire)

1903, appointed Carnegio Rosoarch Follow. 1904-9, Lecturer in Organic Chemistry, United College, University of St. Andrews, and in ehargo of the Chemical Researeh Laboratories. 1909. appointed to tho Professorship of Cheinistry, United Colloge, dorod vacant by the resignation of Professor P'urdie. 
131. Heatheotc, Henry Leonard, B.Sc. (London)

Nominated by Mason University Collcge, Birmingham (now University of Birmingham)

132. Walker, Winifred Esther (Mrs. S. R. Mijner)

Nominated by University College, Bristol (now University of Bristol)

133. Skirrow, Fredcrick William, B.Sc Nominated by Yorkshirc Collegc, Lceds (now University of Lecds)

134. Barkla, Charles Glover, B.Sc.

ominated by University College, Liverpool (now University of Liverpool)

35. Chick, Harriette, B.Sc. Nominated by University College, London

36. Tomlinson, Henry James Nominated by University College, London

137. Lidbury, Frank Austin, B.Sc. Nominated by Owens Colloge, Manchester (now Victoria University of Manchester)
Thompson-Yates Laboratories, Liverpool, and Hygienie Institute, Vicmna

1899-1900

Central 'Techuical College, South Kensington

$1899-1901$

University College, London, and University of Leipzig
Physical Chemistry.-The passivity of iron. The periodic phcnomena accompanying the solution of iron. The action of persulphates on photographic negatives

Radiation. - The measurement of absolute radiation

Physical Chemistry. - Volatility of boric acid in aqueous solutions; the influence of dissolved substances on the solubility of gases in liquids. Oxidation by elcctrolytically separated fluorine

Electricity.-The velocity of elcctric waves along wires. The absorption of electric waves by dielectrics

Bacteriology. - The distribution of bacterium coli commune; the nitrification of sewage: disinfection and other investigations

Plysics.-Pesuarch on contact clifference of potential of inetals

Chemistry.-'The relation betwcen the frecting point of compounds which dissociate on melting, and the composition of the liquid phase:
Sc. Birmingham (1906)

ince 1901, Research Chemist to .

I.Sc. Victorin (1!900).

Ph.D. Leipzig $(1902)$, M.Sc. Leeds (1905)

M.A. Cambridge, M.Sc. Victoria, D.Sc. Isiverpool

D. Sc. London (1903)

Se. Lonclon (1900)

M.Sc. Victoria (1902)
1902-3, Chemist, National Physical Laboratory. Since 1903 Research Chemist to Hardman \& Holden, and the Manchester Oxide Company. Mauchester.

1902-5. Oliver Lodge Fellow: 1905-9, Demonstrator and Assistant Lecturer in Physics, and 1906-9, Lecturer in Advanced Electricity. University of Tivernool. 1!)9, appointed [srofessor of Physics, King's Colloge Iondon-

1901-5, Assistant Bacteriologist, Royal Commission on Siewage Disposal. 1905-7, Jennor Mremorial Sitndent, Lister Institute of Preventive Medi. cine. Since 1907 Assistant, Lister

1900-1. Demonstrator and Assistant Thecturer in P'lysics and Eilectrical Engineering, lleriot-Watt College, Edinburgh. 1901. took up work connected with the manufacture of clectrical instruments. 190., Lecturer in P'hysics, IFar'loy Colloge, Southampton.

1902, Junior Demonstrator in Chemistry, Uweris Colloge. 190:3. Chemist. Oldbury Electro. Chemical Co. Niagarar falls, N.Y. Since 1905 Works Yunager to Old bury licetroChenical Co. Institute of Preventive Medicine. 
LIST OF SCIENCE RESEARCH SCHOLARS APPOINTED BETWEEN THE YEARS 1891 AND 1910-continued.

\begin{tabular}{|c|c|c|c|}
\hline Name of Sullolar & $\begin{array}{l}\text { Years of tenure } \\
\text { of Scholarship }\end{array}$ & Places of study during Scholarship & $\begin{array}{l}\text { Branch of Science } \\
\text { and Principal subjects of Research } \\
\text { during tenure of Scholarship }\end{array}$ \\
\hline $\begin{array}{l}\text { 135. Campbell, William, B.Sc. } \\
\text { Nominated by Durham College of } \\
\text { Seience (now Armstrong Col- } \\
\text { lege, Neweastle-upon-Tyne) }\end{array}$ & $1899-1902$ & $\begin{array}{l}\text { Royal College of Seience, Lon- } \\
\text { don ; Columbia University, } \\
\text { New York; and Royal School } \\
\text { of Hines, London }\end{array}$ & $\begin{array}{l}\text { Metallurgy - Crystallisation produeed } \\
\text { in solid metal by pressure. Miero- } \\
\text { strueture of alloys. The inflnenee } \\
\text { of thermal and meehanical treat- } \\
\text { ment upon alloys and metals }\end{array}$ \\
\hline
\end{tabular}


139. Lownds, Louis, B.Se. Nominated by University College, Nottingham

140. Jenkins, James Travis, B.Se. Nominated by University College of Wales, Aberystwyth

41. Abell, Robert Duncombe, B.Sc. . Nominated by University College of North Wales, Bangor

142 Caldwell. William, B.A.

Nominated by Queen's College, Belfast (now Queen's University of Bolfast)
Physics The olectrical properties of bismuth in the magnetic field

$1899-1901$

University College of Liverpool : Port Erin Biological Station; Zoological Institute, KKiel: Biologieal Institute, Heligoland

University of Loipzig

1899-1901
Ooology.-The mirute anatomy of the statisties; methods and results of German Plankton investigations the otoliths of elupeoids as a eriterion of age oyster; examination of trawlin

Union of acetophenone with phenone.
Ph.D. Berlin

D.Se. Wales,

Ph.D. Kiel ogieal Survey. 1910, transferred to Bureau of Mlinos.

Head of Physies Dopartment, Chelse: Polytechnic.

1903, Professor of 'Zoology, Hartley University College, Southampton. 1907. Superintendent of Fishories for Inoashire and IVesterur Sen rivheries Committere In lous was iven tenve of absence to undertake for Gorepument of Bougal investiention on fisheres and their investigation on fisheries and their control in Bay of Bengal. 1909-10. Published several Reports on the fisheries of the Provinee and Bay of Bengal in the Calcutta Official Gazette 1910, Zoological paper" on Fish of India and Persia in Records of India Muscum. Calcutta. Has now resume uppointment under Lancashire and Western Sea Fisheries Committee.

(1903) Leeturer in Chemistry, University Cl.D.llege of South Wales, Cardif. F.I.C. Lecturer on Organic Chemistry, Newport Technical Histitute. Lecturer on Lnorganic Chemistry, City of Cardiff Technical School. nion of acetophenone with benzily. dene-propiophenone, and of phenyl-

University of Würzburg . . Chemistry.-'Ihe isomerism and tautomcrism of the cyanic acid group of compounds. The -hydroxy-butyric compos diabetes. Polyvalent iodine compounds. Some phosphine comcompounds
II. A. Royal Univer(1903)
Senior Demonstrator in Physiological Department, and Lecturer in Chemsistry and Physiological Chemistry to Indian Civil Service Candidates, Trinity College, Dublin. 
IIST OF SCIENCE RESEARCH SCHOLARS APPOINTED BFTWEEN THE YEARS 1891 AND 1910-continued.

\begin{tabular}{|c|c|c|c|c|c|}
\hline Name of Scholir & $\begin{array}{l}\text { Years of tenure of } \\
\text { Selholarship }\end{array}$ & Places of study during Scholarship & $\begin{array}{l}\text { Branch of Scicucc } \\
\text { and Principsl subjects of Research } \\
\text { during tenure of Scholurship }\end{array}$ & $\begin{array}{l}\text { Degrecs and other dis- } \\
\text { thections obtainetl } \\
\text { siucc appointment to } \\
\text { Scholarship }\end{array}$ & $\begin{array}{l}\text { Particnlars of Seholar's subzeduent earcer } \\
\text { as far is acertained }\end{array}$ \\
\hline $\begin{array}{l}\text { 143. McLean, William B., B.Sc. } \\
\text { Nominated by MeGill University, } \\
\text { Nontreal }\end{array}$ & $1899-1901$ & Owens College, Manchester & Engineering. - Valve leakage & - & $\begin{array}{l}\text { 1901-2, with Crossley Bros, Gas En- } \\
\text { ginc Works, and experimenting for } \\
\text { Nicolson Syndieate. 1902-5, En- } \\
\text { gineer for Union Bridge Iron Works, } \\
\text { Manchester ; 1905-7, Machinery Mer- } \\
\text { chant in. Montreal; 1907-8, with } \\
\text { J. A. Jamicson, Grain Elevator } \\
\text { Engineer, Montreal. Since 190s, } \\
\text { Consulting Enginecr, Montreal. }\end{array}$ \\
\hline $\begin{array}{l}\text { 144. Steele, Bertram Dillon, B.Sc. } \\
\text { Nominated by University of Mrel- } \\
\text { bournc }\end{array}$ & $1899-1902$ & $\begin{array}{l}\text { Laboratory of Pharmaecutical } \\
\text { Society; University of Bres- } \\
\text { lau; and University College, } \\
\text { London }\end{array}$ & $\begin{array}{l}\text { Organie Chemistry--Diamothyldiace- } \\
\text { tylacotone, tetramethylpyrone and } \\
\text { oreinal derivatives from diacety- } \\
\text { lacetone. The measurement of ionie } \\
\text { velocities in aqueous solution and the } \\
\text { existence of complexions. 'Phe trans- } \\
\text { port number of dilute salt solntions }\end{array}$ & D.Se.Melibourne & $\begin{array}{l}\text { Oecupied positions on the stafl of } \\
\text { MeGill University, Montreal, and } \\
\text { the Heriot-Watt College, Edinburgh. } \\
\text { Now lecturer and Demonstrator in } \\
\text { Clremistry, University of Mclbourne. }\end{array}$ \\
\hline $\begin{array}{l}\text { 145. Fawsitt, Charles Edward, B.Se. - } \\
\text { Nominated by University of Edin- } \\
\text { burgl }\end{array}$ & $1900-2$ & University of Leipzig. & $\begin{array}{l}\text { Physienl Chemistry.-The decomposi- } \\
\text { tion of urea }\end{array}$ & $\begin{array}{l}\text { Ph.D. Loipzig, } \\
\text { D.Se. Edin burgh }\end{array}$ & $\begin{array}{l}\text { 1909, Professor of Chemistry. Uni- } \\
\text { versity of Sydney : formerly } \\
\text { Lecturer in Metallurgical Chemistry, } \\
\text { University of Clasgow. }\end{array}$ \\
\hline $\begin{array}{l}\text { 14fi. Blyth, Vincent James, M.A. } \\
\text { Nominated b!y University of } \\
\text { Glasgow }\end{array}$ & $1900-2$ & Cavendish Laboratory & $\begin{array}{l}\text { Physies. - Phe infhence of the magnetic } \\
\text { field on the thermal conduetivity of } \\
\text { metals. Distribution of potential in } \\
\text { the electric discharge betwecn various } \\
\text { electrodes }\end{array}$ & -- & $\begin{array}{l}\text { Lecturer in Natural Philosophy Depart- } \\
\text { ment, Glasgow and West of Scotland } \\
\text { 'I'cehnical Collego, Glasgow. }\end{array}$ \\
\hline $\begin{array}{l}\text { 147. Moir, James, M.A., B.Sc. } \\
\text { Nominated by University of A ber- } \\
\text { decn }\end{array}$ & $1900-2$ & $\begin{array}{l}\text { Central Teclunieal College, South } \\
\text { Kensington }\end{array}$ & $\begin{array}{l}\text { Organic Chemistry }- \text { Derivatives of } \\
\text { diphenol. Synthesis of alkylated } \\
\text { purines }\end{array}$ & $\begin{array}{l}\text { F.C.S. }(1901) \text {, } \\
\text { D.Sc. Aberdecen } \\
\quad(1902)\end{array}$ & $\begin{array}{l}\text { Since 1904, Chemist to Goremment } \\
\text { Mines Department, Johannesburg. } \\
\text { Folmerly chmist in H. Tekstcin \& } \\
\text { Co., Johannesburg. 1906, Vice- } \\
\text { President and 1910, President. of } \\
\text { Chemical Mctallmrgieal Society of } \\
\text { South Afriea. 1908, Fellow and, } \\
\text { 1910. Vicc-President of Royal } \\
\text { Society of South Afriea. }\end{array}$ \\
\hline
\end{tabular}


148. Varley, William Mansergh, B.Sc Nominated by Yorkshire College, Leeds (now University of Lecds)

149. Humfrey, John Charles Willis, B.S.'., B.A.

Nominated by University Colloge, liverpool (now University of Liverpool)

I50. Smiles, Stmuel, B.Sc. Nominated by University Colloge, London

151. Smith, Norman, B.Sc. . Tomenated by Owens College, Manchester (now Victoria University of Manchester)

152. Lloyd, Lorenzo Lyiddon Nominated by University College, Nottingham
$1900-3$

University of Strassburg and Cavendish Laboratory:

Physics.-On the photo-electric dis-

$1900-2$

Engineering Laboratory, University of Cambridge

$900-2$

University of Jena and Professor Moissan's Labolatory,

$$
\text { Paris }
$$

Laboratory of Professor vilu 't Hoff in Berlin and the University of Berlin charge from motallic surfaces in difierent gases and other researches on photo-electric currents

Ph.D. Strassburg, D.Sc. Victoria and Leeds,

B.A. and M.A.

Cambridge

A. Cambridge ngineoring. - Microscopic examina- crystalline structure of motals and of effects of strain

Organic Chemistry ; Mineralogy and Inorganic Chemistry. - Investigation of ethylene oxide and some of its reactions. On $\beta$ methyl morphimethin. On the subject of gases produced by the action of acids on

magncsiun silieide

Chemistry. - The hydrates of magnesium sulphate

D.Sc. London (1901),

Fellow of Univer-

ity College, Londo (1901)

I.Sc. Victoria (1901),

D.Sc Victori (190(i)
1903-8. Assistant Profensor of Physics and Electrical Engincering, MeriotWatt College, Edinburgh. 1904-8, Lxammer in Practical Physics for the Central Welsh Board. 1908-10 Principal of Devomport Techmical School. 1910. Principal of Swansea Technical c'ollege.

1902-9, ongatred 1tpon varions exjerimental and practical researches with Baldwins, Litd., steel manufacturer's, cte. Wilden, Stourport, Worcester. 19019. appointed Assistant. Department of Metallurery and Metallurgical Chemisiry, National Physical Laboratory.

1902, Assistant. Organic Chemistry Department, ibnd. 1907, Assistant Professor of Organic Chemistry, University College, London. Author of Relations between Plysicul Properties and Chemical Constitution, 1910. Ilolds two patcnts for prosulphur dye-stnfts.

1901-5, Assistant Lecturer in Chom. isiry, Owents College, Manchester. 1906, Lecturer and Demonstrator in Chemistry ; 19l0, Scnior Lecturer and Demonstrator in Chemistry, Victoris Univorsity of Jianchester.

University of Berne . . . Chemistry.-Syuthesis of fluvonel and flavone
Sinec 1903 Lecturer in Chemistry Technical Collece, Bradfor engaged in technical research. 
LIST OF SCTENCE RESEARCH SCHOLARS APPOINTED BETWEEN THE YEARS 1891 AND 1910-continued.

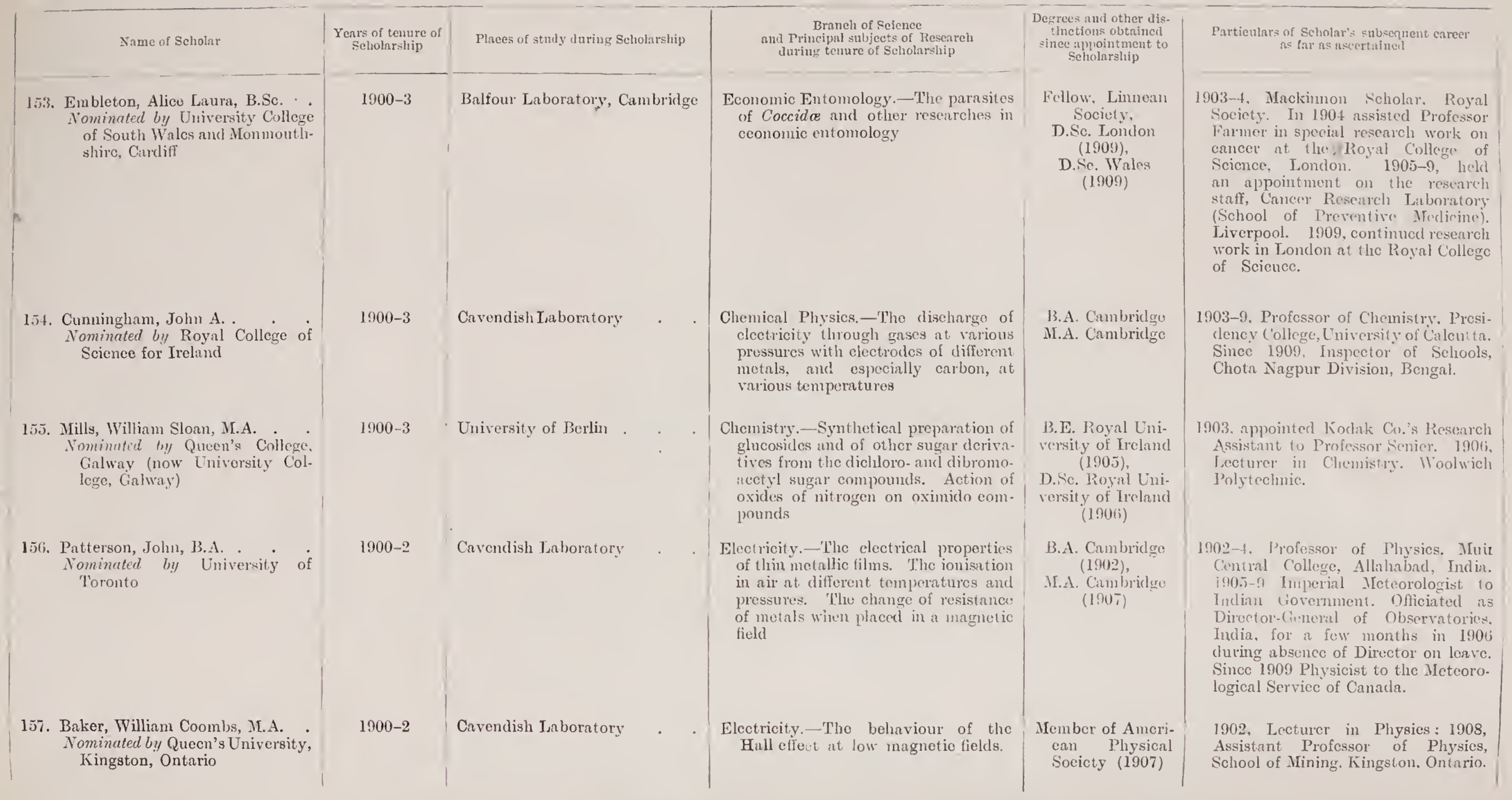


158. Barnes, James, M.A.

Nominated by Dalhousie University, Halifax

159. Durack, Jeremiah J. E., B.A. Nominated by University of Sydney

16C. Horton, Frank, B.Sc. Yominued by theou Luivenity College, Birmingham (now University of Birmingham)

161. Snook, Lilian Blinman Voss, B.Sc. [Lond.] (IIrs. Hudson) Nominated by University Cullege, is ristol (now University of Bristol)

162. Baker, Thomas, B.Sc. Nominated by Durham Colloge science (now Amstron lege, Newcastle-upon-Tyne)

16:3. Craw, John Anderson . Nominated by University of Glas. gow (Appointed for one year only)

] $900-1$

(Bursar)

(Scholar.)

Bursar

(1)

for Scholar-y

ship)

1900-1

(Bursar)

(Scholar) Baltimore

University College, Bristol

Physics.-Electrieal discharge (from

University of Sheffield

\section{University of Göttingen}

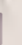
ions moving through a gas at some

Physics. - Sunface tension of mercury ; conditions points) in various gases

hysics.-'The connection betwoen the standard temperature and pressure

Physies. - The effect of temperature on the modulns of torsional rigidity$$
\text { points) in various gases }
$$

Yetallurgy--The influence of silicon on the microstructure, and the mechanical and pliysical properties of iron and the capillary electrometer
1.D. Johns Hopkins University

M.A.

1903-4, Fellow of Johns Hopkins University: Baltimore. 1904-6, Assistant in Physics, Johns Hopkins University. 190ti-10. Associato in Physics ; 1910, Associate Professor of Physics, Bryn Mawr College, Bryn Miawr. Pennsylvania.

Professor of Physics, Allahabad University, Inclia; formerly Lecturer and Demonstrator in Natural Plilosophy, King's College, London.

M.S. Birminghnm (1!) 1 1),

B.A. Cambriclge (1903).

D.Sic. Isondon (1!)03),

M.A. Cambridge (1908)

13.Sc. Bristol (1910)

M.Sc. Durham, I. Mel Shuficl (190S),

li.t.C. (1908) D.Sc. Durham (l) (1)!) Scholar of the Royal tiociet y l904-5.
190:3-4, Ciranville Sicholne, bondon University 1903-1, Mickinnon Allan Scholar, Cunblude Luiversily. Sinec 1905 Supervisol of l'hyic: Stuclies St holno

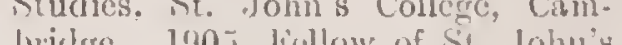
bollo. Collene, Canting Maxwell Scholar, Cambridge University.

1901-3, Science Mistress, Aske 's Haberdashors' Girls' School, West Acton. $190 t-\tilde{5}$, Senior Mathenatical (and Physics) Mistross, Lady Holles' Girls' School, Hackncy.

Since 1911:3 has been works manager and chemist to Now Vanadium Alloys, Ltd. Carnegio Scholar. 19118.

Decosed in June 190:4,

Had been working in the London Hospital Medical College for 3 years, 1906-9. as a (inocers' Prescarch Scholar. 
LIST OF SCIENCE RESEARCH SCHOLARS APPOINTED BETWEEN THE YEARS 1891 AND 1910—conlinued

\begin{tabular}{|c|c|c|c|c|c|}
\hline Name of Scholar & $\begin{array}{l}\text { Years of tenure of } \\
\text { Schoiarship }\end{array}$ & Places of study during Scholarship & $\begin{array}{l}\text { Branch of Science } \\
\text { and Principal subjects of Rcsearch } \\
\text { duriug tculure of Scholurship }\end{array}$ & $\begin{array}{l}\text { Degrces and other dis- } \\
\text { tinctions obtained } \\
\text { since appointment }{ }^{\circ} c \\
\text { Scholarship }\end{array}$ & $\begin{array}{l}\text { Particulars of Scholar's subsequent carcor } \\
\text { As far as aseertined }\end{array}$ \\
\hline $\begin{array}{l}\text { 164. Slator, Arthur, B.Sc. } \\
\text { Nominated by University of Bir- } \\
\text { mingham }\end{array}$ & $1901-3$ & University of Leipzig. & $\begin{array}{l}\text { Chemistry.-The chemieal dynamics } \\
\text { of the chlorination of benzene. The } \\
\text { chemieal dynamics of the reations } \\
\text { of organic halogen compounds. } \\
\text { The dynamies of alcoholic fermenta- } \\
\text { tion. }\end{array}$ & $\begin{array}{l}\text { M.Sc. Birmingham } \\
\text { (1901), } \\
\text { Ph.D. Leipzig } \\
\text { (1903), } \\
\text { F.I.C. (1905) } \\
\text { D.Se. Birminghan } \\
\text { (1906) } \\
\text { D.Se. London (1910) }\end{array}$ & $\begin{array}{l}\text { 1903-5, Lecturer and Deinonstrator, } \\
\text { Unirenity College, Nottingham. } \\
\text { Since } 190 \text {. Researeh Chemist to } \\
\text { Bass, Rntcliff \& Gretton, Burton- } \\
\text { on-Trent. }\end{array}$ \\
\hline $\begin{array}{l}\text { 165. Denison, Robert Beekett, B.Se. } \\
\text { Nominaled by Yorkshire College, } \\
\text { Leeds (now University of } \\
\text { Leeds) }\end{array}$ & $1901-4$ & $\begin{array}{l}\text { University of Breslau; Uni- } \\
\text { versity of Berlin; University } \\
\text { College, London }\end{array}$ & $\begin{array}{l}\text { Physical Chemistry.-Transport num- } \\
\text { ber measurements in extremely } \\
\text { dilute solution. Direet mensure- } \\
\text { ment of transport numbers with } \\
\text { speeial regard to the influence of } \\
\text { endosmose. On the possible eo- } \\
\text { existence of astrakanite and kainite. } \\
\text { On the vapour tensions of saturated } \\
\text { salt solutions. On the equilibrium } \\
\text { of sodium and magnesium sul- } \\
\text { plates. Investigations upon certain } \\
\text { rare minerals }\end{array}$ & $\begin{array}{l}\text { Ph.D. Breslau } \\
(1903) \\
\text { H.Sc. Leeds } \\
\quad(1905) \\
\text { D.Sc. Leeds } \\
(1007)\end{array}$ & $\begin{array}{l}\text { 1905, Leeturer' } 1906 \text {, Assistant Pro- } \\
\text { fessor and Chief Assistant. in } \\
\text { Chemistry, Heriot, - Watt College. } \\
\text { Edimburgh : 1910. Professorof Chem- } \\
\text { istry and Physics, Natal University } \\
\text { College, Pietermaritzburg. }\end{array}$ \\
\hline $\begin{array}{l}\text { 166. Owen, Gwilym, B.Se. } \\
\text { Nominated by University College. } \\
\text { Liverpool (now University of } \\
\text { Liverpool) }\end{array}$ & $1901-1$ & Cavendislı Laboratory & $\begin{array}{l}\text { Physics.-On the proportion of eor- } \\
\text { puscles and partieles in the negative } \\
\text { radiation from hot platinum. On } \\
\text { the eonclensation nuelei from hot } \\
\text { platinum. On the discharge of } \\
\text { electrieity from Nernst lilaments }\end{array}$ & $\begin{array}{l}\text { B.A. Cambridge } \\
(1904) \text {, } \\
\text { II.A. Cambridge } \\
(1907) \text {. } \\
\text { D.sc. Liverpool } \\
(190 \mathrm{~s})\end{array}$ & 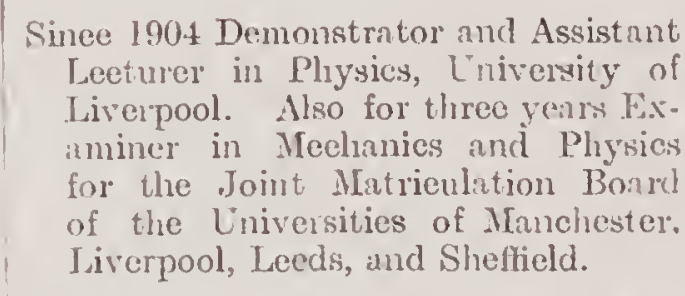 \\
\hline $\begin{array}{l}\text { 167. Senter, George, B.Sc. } \\
\text { Nominated by University College, } \\
\text { London }\end{array}$ & $1901-3$ & $\begin{array}{l}\text { University of Leipzig and } \\
\text { Göttingen }\end{array}$ & $\begin{array}{l}\text { Chemistry.-Investigations of organic } \\
\text { eatalysors }\end{array}$ & $\begin{array}{l}\text { Pl..D. Luiprig } \\
\text { D.Sc. London }\end{array}$ & $\begin{array}{l}\text { Lecturer in Chenistry, Sir Joln Cass } \\
\text { Institute and St. Mary's Hospital } \\
\text { Medieal school. Examiner in } \\
\text { Chemistry, Royal College of Phy- } \\
\text { sieians of London and Royn } \\
\text { College of Surgens of England. } \\
\text { Member of Couneil of the Faraday } \\
\text { Soeiety. Author of "Outlines of } \\
\text { l'hysical Chemistry" (Methuen \& Co. } \\
\text { 1909). }\end{array}$ \\
\hline
\end{tabular}


168. Rixon, Frederic Willian, B.Se. Nominuled by Uwens Colloge, Manchester (now Victoria University of Manchestor)

169. Laws, Samuel Charles, B.Sc. Nominaled by University College, Nottinghain

170. Smith, Alice Emily, B.Sc. Nominated by University Collegro of North Wales, Bangor

171. Hawthorne, Joln, B.A. Nominated by Quecn's Collego, Belfast (now Queen's University of Belfast)

172. McClung, Robert K., M.A. . Nominnted by McGill Universily, Montroal

173. Dickson, Charles William, M.A. Tominuted by Queen's University Kingstou, Ontario
hysics.-'Thermo-eloetric and thermomagnetic propertics of alloys of bismuth and tin

Organic Chemistry. - Synthesis of dimethylglutaric acid and di-methylglutaconic aeid. Synthesis of trimothylolutaric acid and of tri-mothylglutaconic acid

University of Jena . . . Organic Chemistry. - Durivatives of morphline

lectricity.-Efiect of temperature on rate of recombination of ions. Effect of temperature of gases on the ionisation produced by Rontgen rays in these gases. Rolative imount of ionisation produced in gasos by Röntgen rays of differont types

Columbia University, New York, and University of Hcidclberg
Geology, Chemistry, and Mctallurgy.The Sudbury ore deposits, geologically, chemically, and inineralogically. Condition of platinum in various ores. 'I'he nickcl-coppor oro deyosits ncar St. Stephen, Canada
Sc. Victoria (1903), h.D. Giesser (1903)

B.A. Cambridge $(190$ !)

I.A. Cambricly (1908)

Ph.D. Jena

A. Cambridge D.Sc. McGi

Plı.D. Columbia
1907, Assistrut P'rofessor of Chemistry, Terchant Vonturors' 'J'echmical College, Bristol; proviously Ifead Science Master, Newton Abbot. 'Pechinical Schools. Since 1909 Lecturer in Chemistry, University of Bristol.

1904-5, Junior Lecturer in Physics at King's College, Tondon. 1905-0!), Head of Pliysics Department, Technical School, Blackburn. Since 1909 Principal of the 'Teclinical Institute, Loughborough.

Assistant Lecturer in Clionistry at the University College of North Wales.

1903, Junior Fellow. Royal Univorsity of Ireland. 1904, Assistunt Lecture in Clomistry, Queen's Col leote, Cork. Sinuo 1006 Profossor of Chemistry, Munieipal 'l'echnical In. stitute, Belfast.

$1904-\bar{\gamma}$, Senior Demonstrator of Plyysics, McGill University. Mont roul. 1907-9. Professor of Physics, Mount Allison Lniverxity, Sackville. New Brunswick. Since 1909 Lecturer in Physics. University of Manitoba, Winnipeg. Ellector, 1908 , Fellow of the American Association for the Advancement of Science.

Irecturer in Chemistry, School of Mining, Kingston, Ontario. 
LIST OF SCIENCE RESEARCH SCHOLARS APPOINTED BETWEEN THE YEARS 1891 AND 1910-continued.

Name of Scholar

Years of tcmure
of Scholarship

174. Harkcr, George, B.Se Nominated by University of Sydnoy

175. MacLaren, James Halcolm, D.Se. Vominuted by University of Now Zealand

76. Dow, Charlcs Robert, 13.Sc. . Nominated by Durhain College of Science (now Armstrong Co lege, Ncweastle-upon-'Iyne

177. Wraterhouse, George Booker Nominated by University College. Sheffield (now University of Shefficld)

178. Cooke, William Ternent, B.Se. Nominaled by University of Ade. laide
-

Places of study during Scholarship

Central Ticehnical College, Lon dor

$1901-2$

Royal Institution . . .

1901-2

(Bursar) (Scholar")

Bursar 1901-2) Scholar $(1902-4)$

1901-2 (Bursar) $1902-4$ (Scholar)

Durham College of Seicnce Königliche Trechnische Hochschule, Aachen, Prussia

Colnmbin University, New Yor

University College, London

Degrees and other di since appointment th Scholurship

Branch of Science
amm Principal subjocts of Resenre
during temure of Scholarship

Organic Chemistry.-The thio derivatives of the xylenes

D.Sc. London

Metallurgy.-The influence of sulphur researel. Influenee of niekel inc and mangancse on steel. Bar iron enrbon on iron. 'The burning, overheating, and restoring of nickel stee

Chemistry.-The ignition of mixtures of marsh gas and air with reference to the use of electricity in mines

Inorganic Chemistry.-On the reduetion of hydrazoic acid. Experiments on the vapour densities of zine and other metals
M.Se. Durliam $(1 !(05)$

h.D. Columbin (1907)

3.Met. Shefficli $(1907)$

D.Sc. Adelnide (1905)

Particulars of Scholar's anbseqnent career ith fin as nscertainet

Since 1903 Research Chenist to the Colonial Sugar liefining Co.. Itte. Australia. Inventor of the Harke Patent Fire Fxtingtisher and Fimigator, whiel is now being used witl marked sucecss on ships.

1901-6, Mining Adviser to Government of Inclia. 1906-8, author of "Gold its geological oceurrenee and gcographieal distribution " (London, 1908). 1908-10, engaged in the cramination of the Kalgurli goldfield, Western Australia.

1904-7, Science Master, Endowed Sehools, Strond, and Iucturer in Cheoris shol of Che stroud Since 1007 Che a Art, shre I'echnical Institute, Belvedcrc, Kent.

1904-(i, Assistant I'rofessor, Dopart ment of Metallungy, Columbia University, New York. 1907-10, Pro fessor of Metallurgy, an! 1910 Special Leeturer in Mctallurgy, University of Buffalo. Also, 1906-10, Metallographist, Lackawanna Stee Co., Buffalo, N.Y.. and sinee 1910 Jetallurgist with same Company.

Appointed, 1906, Leeturer on Chemistry, as assistant to the Profosor, istry, as assisty of ternel lexauiner in Assaying to the School of lings, South Schoun in Inorenic Chemistry to Examiner in Inorganic Chemistry to Australia. 
179. Inglis, John K. H., M.A., B.Sc. Nominated by University of Edirburgh

180. Wood, Alexander, B.Sc. Nominated by University of Glas gow

181. Wallace, William, B.Sc. Nominated by University of St. Andrews

182. Michie, Arthur Cumming, B. Sc. Nominated by University of Abcrdcen

183. Lloyd, John Alexander, B.Sc (London), M.Sc. (Birming ham), F.I.C. minated by University of Bir-
Zoological Stations, Plymouth and Naples

$1902-$

Unircrsity of Leipzig .

Physical Chemistry.-The clectrolytic behaviour of uranium salts

Chemistry.-Suggested theory of the aluminium anode. The loss of nitro distillation

Physics.-Radio-activity of ordinary metals and of salts of the alkal metals. Diumal periodicity of spontaneous ionisation in closed metn vessels

Marine Zoology.-Ovaries of fishcs and of tomopteris

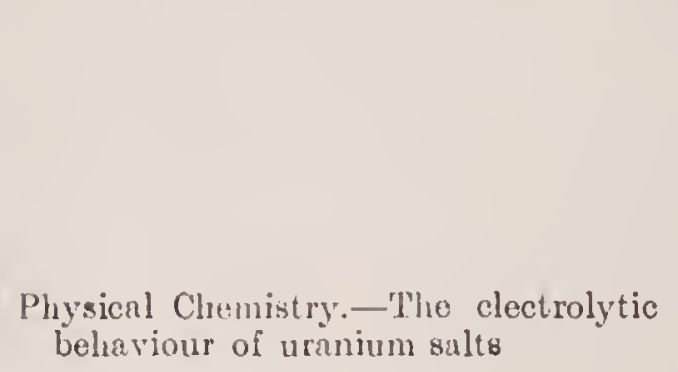
mingham
D.Sc. Aberdeen (1906)

A. Cambridg (1904)

MI.A. Cambridge (1909), (1906),

Fellow of Emmannel College (1907)

D.Sc. St. Andrews $(1904)$

Resigned his Scholarship Christmas, 1903, on being appointed Assistant in Chencal Departhon of University Collcge, London. In 1906 appointcd Lecturor and in 1007 Professor of Chemistry, University College, Reading.

1904, Supcrvisor of Studics in Physice and Chemistry; 1905, Lecturer in Physics and Chenistry, Emmanue College. 1908. University Demonstrator in Physics. 1910, Tutor of Emmanuel Collcge.

Resigned at end of first ycar on being appointed Naturalist to the Marine Biological Association of the United Kingdom. 1910. appointed to the Board of Agriculture and Fishcric as Naturalist for International Fish cry Investigations.

Appointed, 1906, tcchnical chemist to Merz \& HcLellan. Consulting Elcctrical Enginccrs, Newcastle - on - Tyue, nnd transferred in 1908 to their Wallsend Laboratories.

Ph.D. Würzhurg (1903) of nity.-The pscudo-basic nature of nitro-anilines and nitrosoanilines. ducts

Resigned his scholarship in September 1903, on bcing appointed to the Chomical and Patcnt Staff of the Badische Anilin und Soda Fabrik, Ludwigshafen am Rhein, which position he still holds. 
LIST. OF SCTENCE RESEARCH“SGHOLARS APPOINTED BETWEEN THE YEARS 1891 AND 1910-continued.

\begin{tabular}{|c|c|c|c|}
\hline Name of Scholar & $\begin{array}{l}\text { Years of tenure } \\
\text { of Sebolarship }\end{array}$ & Places of study during Scholarship & $\begin{array}{l}\text { Brnuch of Science } \\
\text { and Principsl subjects of Besenrch } \\
\text { during teuure of Scholarship }\end{array}$ \\
\hline $\begin{array}{l}\text { 184. Dakin, Henry Drysdale, B.Se. } \\
\text { Nominated by Yorkshire Collego, } \\
\text { Lceds (now University of } \\
\text { Leeds) }\end{array}$ & $1902-5$ & $\begin{array}{l}\text { Jenner Institute and University } \\
\text { of Hoidelberg }\end{array}$ & $\begin{array}{l}\text { Physiological Chemistry. - Chemistry } \\
\text { of onzymos }\end{array}$ \\
\hline $\begin{array}{l}\text { 185. Rogers, Frank, B.Sc. . } \\
\text { Vominated by University Collego, } \\
\text { Liverpool (now Univorsity of } \\
\text { Liverpool) }\end{array}$ & $1902-4$ & $\begin{array}{l}\text { Enginooring Laboratory, Cam. } \\
\text { bridgo }\end{array}$ & $\begin{array}{l}\text { Engineering.-Ropetition of stress on } \\
\text { steol }\end{array}$ \\
\hline $\begin{array}{l}\text { 186. Harrison, Edward Philip } \\
\text { Nominated by University College, } \\
\text { London }\end{array}$ & $1902-5$ & $\begin{array}{l}\text { Fedoral Polytechnie, Zürich, and } \\
\text { Cavendish Laborntory }\end{array}$ & $\begin{array}{l}\text { Physies. - The magnetie properties of } \\
\text { iron, niekel, and cobalt }\end{array}$ \\
\hline $\begin{array}{l}\text { 187. Simpson, George Clarke, B.Se. . } \\
\text { Nominated by Owens Callege, } \\
\text { Manehester (now Victoria. Uni- } \\
\text { versity of Manchester) }\end{array}$ & $1902-5$ & $\begin{array}{l}\text { University of Göttingen and the } \\
\text { village of Karasjok, Norway, } \\
\text { and the Meteorological Office, } \\
\text { London }\end{array}$ & $\begin{array}{l}\text { Atmospherie Electricity.-The absorp- } \\
\text { tion of elcctricity from ionised air. } \\
\text { Observatious in atmospherie clee- } \\
\text { trieity. Atmospherie electricity in } \\
\text { high latitudes. The relation between } \\
\text { the Beaufort seale and the velocity } \\
\text { of wind }\end{array}$ \\
\hline
\end{tabular}

\begin{tabular}{|c|c|}
\hline $\begin{array}{l}\text { Degrees and other dis- } \\
\text { tinctions obtained } \\
\text { since appointment to } \\
\text { Scholarship }\end{array}$ & $\begin{array}{l}\text { Particulars of Scholar's subsequent career } \\
\text { ns far as uscertiuned }\end{array}$ \\
\hline $\begin{array}{c}\text { F.I.C. } \\
(1902) \\
\text { M.Nc. Inods, and } \\
\text { D.Sc. Loods } \\
(1907)\end{array}$ & $\begin{array}{l}\text { Engraged in independent research in } \\
\text { private laboratory of Dr. C. A. } \\
\text { Herter, New York. During the } \\
\text { last three yoars his ehiof subject of } \\
\text { research has been the chemieal } \\
\text { aspects of the oxidation processes of } \\
\text { the animal body, the results of which } \\
\text { have been publishcd mainly in the } \\
\text { Journal of Biologicul Chemistry, } \\
\text { New York. }\end{array}$ \\
\hline $\begin{array}{l}\text { B.A. Cambridge, } \\
\text { M.Sc. Victoria, } \\
\text { LI.Eng. Liverpool }\end{array}$ & 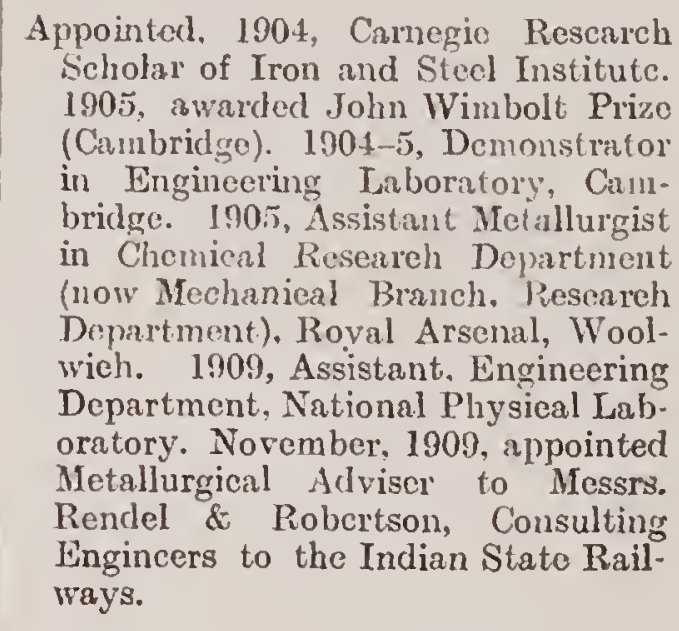 \\
\hline $\begin{array}{l}\text { Ph.D. Ziirich, } \\
\text { B.A. Cambridge }\end{array}$ & $\begin{array}{l}\text { Professor of Physies, Presidency College, } \\
\text { University of Calcutta. }\end{array}$ \\
\hline $\begin{array}{l}\text { M.Se. Victoria } \\
\text { (1905), } \\
\text { D.Sc. Victoria } \\
(1306)\end{array}$ & $\begin{array}{l}\text { 1905, Leeturer in Meteorology and } \\
\text { Assistant Leeturer in Physics, Vic- } \\
\text { toria University of Manehester. } \\
\text { 1906. Scicntific Assistant, Mcteoro- } \\
\text { logical Office, Simla, India. Now } \\
\text { Physicist and Meteorologist to the } \\
\text { British Antarctic Expedition 1910. }\end{array}$ \\
\hline
\end{tabular}


188. Goodwin, William, B.Se.

Nominated by Queen's College, Galway (now Univorsity Col. lege, Galway)

189. Bray, William Crowell, B.A. Nominated by University of Toronto

190. Hcbb, Thomas Carlyle, M.A. Nominated by Dalhousie University, Halifax, Nova Scotia

191. Hosking, Riehard - $\cdot$. bourne

192. Hunter, Matthew Albert, B.Sc. Nominated by University of New Zealand
University of Göttingen and Chemistry.-Chemistry of the carbo. Museum of Natural History, Paris

$1902-4$

University of Leipzig. - . Physical Chemistry.-The behaviour of chlorine dioxide, chlorous acid and chlorites in solution: the primary oxidation of iodide-ion; the use of the differential equation in calculating the results of kinetic nreasurements.

$1902-4$

Chicago University . .

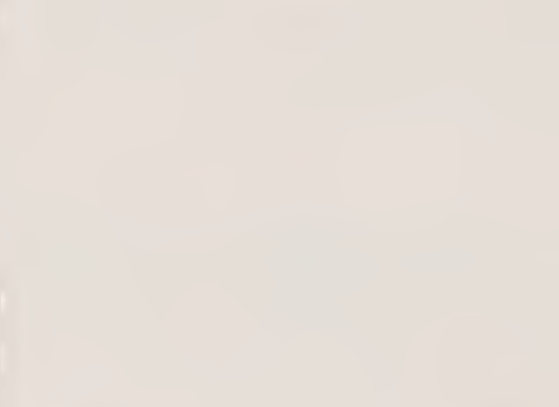

$1902-5$

Cavendish Laboratory, and University of Sydney

$1902-5$

M.Sc. Victoria,

Physics.-The determination of the velocity of sound

Physics.-The fluidity and electrieal conductivity of solutions. Viscosity of liquids at high rates of shear

University College, London, University of Göttingen. University of Paris, and Techn
cal High Sehool, Karlsruhe by the presence of other liquefied
Inorganic Chemistry.-Lowcring the vapour pressures of liquefied gases gases dissolved in thein. The com. plexity and chenical propertics of thorium
Ph.D. Göttingen

Ph.D. Leipzig (1905)

1904-6, research in Chemistry at Manohester and Göttingen. 1906, Lecturer on Chemistry alld Physics, Harper-Adams Agricultural College, Newport, Salop. 1907, Lecturer on Agricultural Chemistry and Head of Chenistry Dopartment, SouthEastern Agricultural College, IVye, Kent, and Examiner in Agrioultural Chemistry. University of London.

1905-10, Rescarch Associate, and since 1910 Assistant Professor of PhysicoChemical Research, Massachusetts Institute of Technology, Boston, Mass., U.S.A.

Ph.D. Chicago

904-5, Lecturer in Physics, Dalhousie College. 1905-6, Instructor in Physics, Central High School, St. Louis, Illinois. 1906-7, Assistant for the American Tclephone and Tele. graph Co., and Westinghouse Electric \& Manufacturing Co. Since 1907 Head of Physics and Chemistry Departmeuts, Northern State Nor. mal School, Mrarquette, Michigall.

B.A. Cambridge

Physics Master, Sydney Grammar Sehool, New South Wales.

D.Sc. London

Working in research Laboratory, General Electric Co., New York Assistant Professor of Physics and Electrochemistry, Rcusselaer Poly. technic Institute, Troy, N.Y. 
LIST OF SCIENCE-RESEARCH SCHOLARS APPOJNTED BETWEEN THE YEARS I891 AND 1910-continued.

\begin{tabular}{|c|c|c|c|c|c|}
\hline Name of Scholar & $\begin{array}{l}\text { Years of tenure of } \\
\text { Scholarship }\end{array}$ & Places of study during Scholarship & $\begin{array}{l}\text { Branch of Science } \\
\text { and Principal subjects of Research } \\
\text { during tenure of Scholarship }\end{array}$ & $\begin{array}{l}\text { Degrees and other dis- } \\
\text { tinctions obtained } \\
\text { since appointment to } \\
\text { Scholarship }\end{array}$ & $\begin{array}{c}\text { Particulars of Scholar's subsequent carecr } \\
\text { os far as aseertained }\end{array}$ \\
\hline $\begin{array}{l}\text { 193. Radford, Catherine, B.Se. (Mrs. } \\
\text { J. F. Dow) } \\
\text { Nominaled by University Collegc, } \\
\text { Shefficld (now University of } \\
\text { Sheffield) }\end{array}$ & $\begin{array}{l}\text { Bursar } \\
(1902-3) \\
\text { Scholar } \\
(1903-5)\end{array}$ & $\begin{array}{l}\text { Vietoria University of Man- } \\
\text { chester }\end{array}$ & $\begin{array}{l}\text { Physics.-Mapping the speetra of the } \\
\text { oxides, chlorides, bromides and } \\
\text { joclides of barium, strontium, and } \\
\text { calcium }\end{array}$ & $\begin{array}{l}\text { B.Se. Shoffield } \\
(1908)\end{array}$ & $\begin{array}{l}\text { 1905-8, Physies and Mathomaties } \\
\text { Mistress, Manchester High School } \\
\text { for Cirls. Sineo } 1909 \text { Assistant } \\
\text { Examiner in Mathematies for Joint } \\
\text { Matriculation Board for Manchester, } \\
\text { Liverpool, Leeds, and Sheffield Uni- } \\
\text { versities. }\end{array}$ \\
\hline $\begin{array}{l}\text { 194. Thompson, Kenworthy James, } \\
\text { B.Se. } \\
\text { Nominated by University Collego } \\
\text { of Wales, Abcrystwyth }\end{array}$ & $\begin{array}{l}\text { Bursar } \\
(1902-3) \\
\text { Scholar } \\
(1903-5)\end{array}$ & $\begin{array}{l}\text { University College, Aberyst- } \\
\text { wyth, and University of Loip. } \\
\text { zig }\end{array}$ & $\begin{array}{l}\text { Organie Chemistry. - The action of } \\
\text { alkalis on einnamic-acid dibromide } \\
\text { and its esters. On } \beta \text { bromo- } \\
\text { cinnamic acids and on diazonium } \\
\text { compounds }\end{array}$ & Ph.D. Leipzig & $\begin{array}{l}\text { Agrieultural Chemist to Liverpool In- } \\
\text { stitute for Commereial Researeh in } \\
\text { the Tropics. }\end{array}$ \\
\hline $\begin{array}{l}\text { 105. Edmonds, Sydney Arthur, } \\
\text { A.R.C.Se.I. } \\
\text { Nominated by Royal College of } \\
\text { Science, Dublin }\end{array}$ & $\begin{array}{l}1902-3 \\
(\text { Bursar) } \\
1903-5 \\
\text { (Scholar) }\end{array}$ & $\begin{array}{l}\text { Royal Collego of Seionec for } \\
\text { Ireland and Cavendish } \\
\text { Laboratory }\end{array}$ & $\begin{array}{l}\text { Physics.- The thermal conductivity } \\
\text { of some alloys of iron. Quasi-radio } \\
\text { activity induced by the point dis- } \\
\text { charge, and an investigation of the } \\
\text { ratio betwecn the rclocities of the } \\
\text { positive and negative ions in mona- } \\
\text { tomic gases }\end{array}$ & I.R.C.Se.I. & $\begin{array}{l}\text { 1905-7, Oliver Lodge Fellow, Univer- } \\
\text { sity of Lircrpool. 1907, Assistant } \\
\text { Demonstrator, and } 1910, \Lambda \text { ssistant } \\
\text { Leeturer and Demonstrator in Phy- } \\
\text { sies, University of Leeds. }\end{array}$ \\
\hline $\begin{array}{l}\text { 196. Stewart, Alfred Walter, B,Se. } \\
\text { Nominaled by University of Glas- } \\
\text { gow }\end{array}$ & $1903-5$ & University Colloge, London & $\begin{array}{l}\text { Organic Chemistry.-Addition of so- } \\
\text { dium bisulphite to ketones and } \\
\text { veloeity of oxime formation }\end{array}$ & $\begin{array}{l}\text { D.Se. Cilasgow } \\
(1907)\end{array}$ & $\begin{array}{l}\text { 1905-8, Carnegio Researeh Fellow. } \\
\text { 1907-9, Leeturer in Stereo-Che- } \\
\text { mistry, University College, London. } \\
\text { Sinee 1909, Lecturerfon Organic } \\
\text { Chemistry, Quecn's University, Bcl- } \\
\text { fast. A uthor of "Stereochemistry " } \\
\text { (1907); "Recent Advanees in O1- } \\
\text { ganie Chemistry" (1908); Stereo- } \\
\text { ehemie" (1909); iand " "Recent } \\
\text { Advances in Physieal "and Inor- } \\
\text { ganie Chemistry" (1909). }\end{array}$ \\
\hline $\begin{array}{l}\text { 197. Paul, David MeLaren, B.Se. } \\
\text { Nominated by University of St. } \\
\text { Andrews }\end{array}$ & $1903-5$ & University of Berlin . . & $\begin{array}{l}\text { Organic Clemistry.-On acids contain- } \\
\text { ing an asymmetric carbon atom. } \\
\text { On asymmetrie synthesis and dera- } \\
\text { cemisation }\end{array}$ & - & $\begin{array}{l}\text { 1907-8, Tomporary Chemieal Assistant } \\
\text { at Researel. Department, Royal } \\
\text { Arsenal, Woolwich. 1908, chemist } \\
\text { to Messrs. Curtis's \& Harvey, ex- } \\
\text { plosives manufacturers, Cliffe, Kent, } \\
\text { and transferred in } 1909 \text { to their } \\
\text { Tonbridge factory. }\end{array}$ \\
\hline
\end{tabular}


198. Gebhard, Norman Leslie, B.Sc. (London), M.Sc. (Birmingham) Nominated by Universifty o Birmingham

199. Gaunt, Rufus, B.Sc. ${ }_{\text {Nominated by Yorkshire College, }}$ Nominated by Yorkshire College, Leeds (now University of Leeds)

200. Spenccr, James Frederick, B.Sc. . Nominated by University College, Liverpool (now University of Liverpool)

201. Bassett, Henry, B.Se., A.I.C. • Nominated by University College, london

202. Bradshaw, Lawrence, B.Sc. . Nouninated by Owens College, Manchester (now Victoria University of Manchestor)

203. Black, Thomas Portcous, M.A., B.Sc.

Nominated by Durham College of Science (now Armstrong College, Newcastle-upon-Tyne)
Federal Polytechnie, Zürich - Organic Chemistry.-Concerning deriatives of glyoxim and mononitroglyoxim \& glyoxin, \&ce, an organic chemical rescarches

Chemistry. - On the acetic fermentation

1903-6

University of Breslau and University College, London

Universitics of Munich and Nancy

$1903-6$

1903-5 Univcrsity of Strassburg - . $\quad \begin{gathered}\text { Elcctricity.-On the resistance of coils } \\ \text { of wire for electrical oscillations of }\end{gathered}$ high frequency

Chemistry.-On the elcctro-chemistry of thallium compounds. The action of ultra-violet light on metals and compounds. Dilute amalgams. Magnesium and other metals in their action on organic halides. Quantitative separation of silver and thallium

Chemistry (Organic and Inorganic).Rescarch in ortho-amido-triphenylregard to their evidence in support of the quinonoid formula of the Fuchsine dyes Victoria University of Man chester

Chemistry.-On the elcctrolytic oxidation of nitrites; on the elcctrolytic dissociation of some coinplex salts ; on the tempcratures of the volatilisation of metals in the electric furnace
Ph.D. Basle

ntíl 1909, Lecturer and Demonstrator in Chemigtry at Iumicipal Technica School, Derby. Now with the Nera Stearine Co., Moscow, as chict chemist witl teelnnical control of Moscow works.

Ph.D. Berlin

University of Giessen and

Ph.D. Breslau (1904),

M.Sc. Liverpool (1903),

D.Sc. Liverpool (1907)

Ph.D. Munich (1904)

D. es Sc. Nancy (190:),

F.I.C. $(1905)$ (1008) (1908)

M.Sc. Victoria (1903),

Ph.D. Giessen (1905),

D.Sc. Victoria (1907)

Ph.D. Strassburg $(1905)$

M.Sc. Durham (1906)
Assistant 1ecturer on Agricultural Chemistry, University College of North Wales, Bangor.

Since 1906 Lecturer in Chemistry, Bedford College, University of Lon don, and Demonstrator in Chemistry at Sir John Cass T'echnical Institute.

Since 1905 Demonstrator and Assistant Lecturer in Chemistry, Cniversity of Liverpool. Has becn engaged in hydrographic investigations in the Irish Sea.

1906-7. Tccturer in Chemistry, Harper-Adams Agricultural College, Newport, Salop. 1907-8, Schunck Research Assistant in Chemistry, Victoria University of Manchester. Since 1908 Assistant Manager of the Jackus \& Johnston Mlining and Smolting Works, Casapalca, Peru.

1905-6, Demonstrator in Physics, Arm strong College, and since 1906 lecturer and Demonstrator in Physics, University College, Nottingliam. 
LIST OF SCIENCE RESEARCH SCHOLARS APPOINTED BETWEEN THE YEARS 1891 AND 1910-continued.

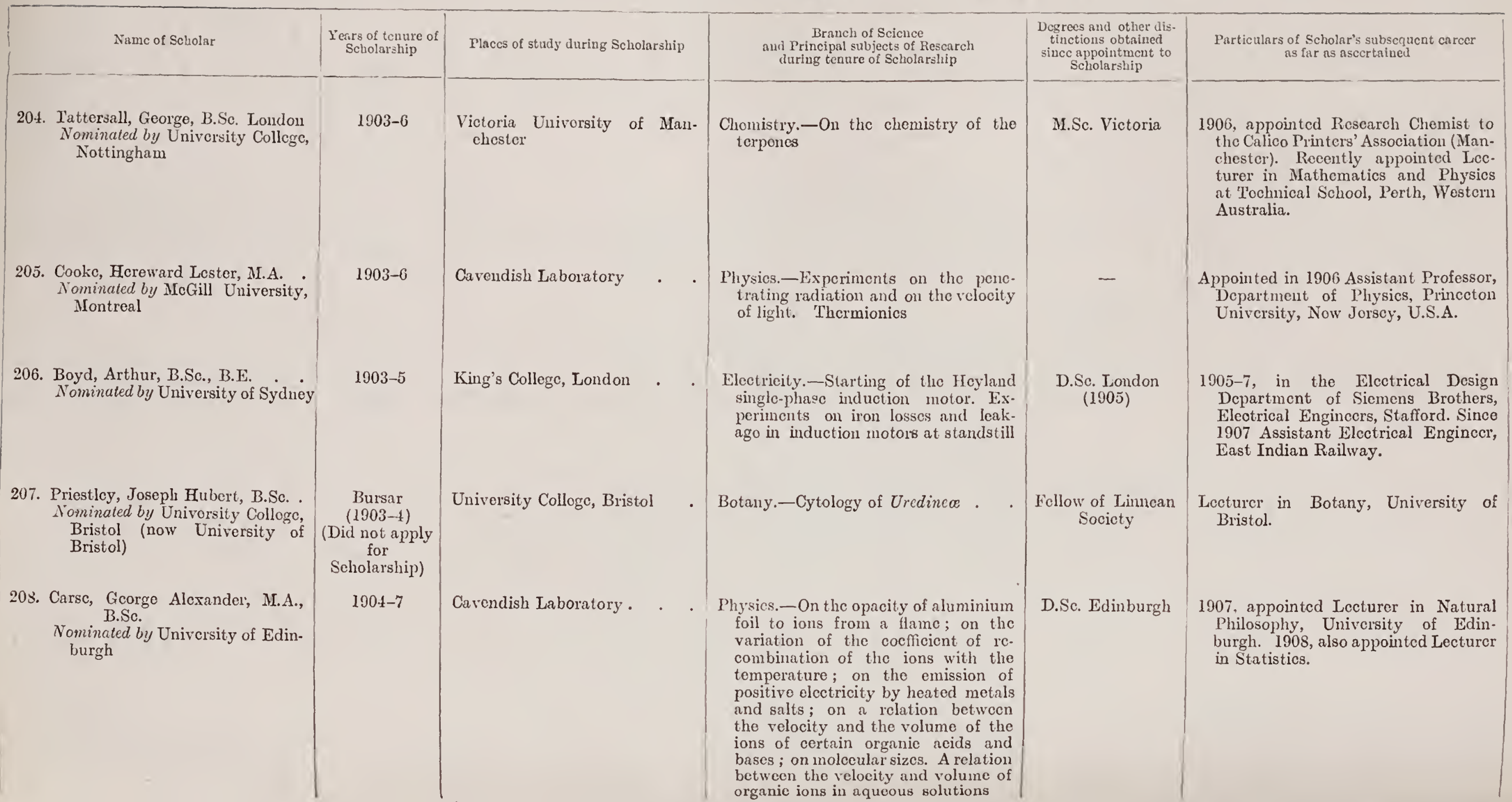


209. Houstoun, Robert Alexander, I.A., B.Sc.

Nominated by University of Glasgow

210. Knox, Joseph. B.Se. Nominated by University of Aberdeen

211. Phillips. Percy, MI.Se. . Nominated by University of Birmingham

212. Raper, Henry Stanley, B.Se., Nominated by University of Leeds

213. Haworth, Harold Firth, B.Se. Nominated by Unirersity of Liverpool

214. Noble, Henry Robertson, B.Se. Nominated by University College, London Cavendish Laboratory

$1904-6$

$1904-6$

$1901-7$

$1904-5$
Foderal Polytechnie, Zür`ich

University of Breslau

Cavendish Laboratory

Lister Institute of Preventive Medicine and University of Strassburg

University of Giessen . ture on the absorption bands solids and liquids. T'he effect of a Total-refleetion at the seeond sur. free of a thin plane parallel plate

Clemistry.-The nature of the ionie equilibrium in eomplex solutions eontaining mereury and sulphur

D.Se. Aberdeen

I

Plyysies.-Determination of the reloeities of the ions produeed by Röntgen rays in air at different temperatures

Chemistry.-The influence of position isomerism upon optieal aetivity in organie eompounds; the synthesis o fatty aeids from laetie aeid ; the eon densation of aldol. The eomposition of peptonle

Physies and Electroteehnies. - The eleetrieal qualities of poreclain

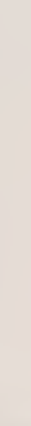

Physies-Optieal phenomena of vapours, especially fluorescence and absorption
Ph.D. Göttingen (1906),

D.Se. Glasgow

(1907) (1907)

Sinee 1906 Assistant in Natural Philosophy, and sinee 1908, Leeturer on Optics (Natural Philosopliy Depart ment), University of Glasgow.

1906-9, Assistant to Professor of Cliemistry, and Carnegie Researeh Fellow, Aberdeen University. 1909, appointed Lecturer in Inorganie Chemis. try, University of Aberdeen.

B.A. Cambridge (1906),

D.Se. Birmingham (1907)

M.Se. Teeds I.B., Ch. B. Leeds Professor o Veterinary College at the Royal sinee 1906.

Formerly engaged in Researeh work, Physiologieal Laboratory of Lorls Uhivelogity a Laboratory of Leeds Universily, also Dow thologieal Chemistry, University of Toronto, Canada.

3.Eng. Liverpool, Pli.D. Basle, M.Se. Vietoria

Formerly Demonstrator and Assistant Leeturer in Elcetrotechinies, Central Teelmieal College, South Kensington, and Head of the Physies De. partment (Board of Edueation Evening Classes) of 'Tottenham Polyteehnic. 1910, Head of Electrieal Engineering Department at Aeton and Chiswiek Polytechnic (Evening Classes). Nember of the Eleetrieal Engineering Board of Studies of the University of London. 
LIST OF SCIENCE RESEARCH SCHOLARS APPOINTED BETWEEN THE YEARS 1891 AND 191G-continued.

\begin{tabular}{|c|c|c|c|c|c|}
\hline Name of Scholar & $\begin{array}{c}\text { Years of tenure of } \\
\text { Scbolarship }\end{array}$ & Places of study duriug Scholarship & $\begin{array}{l}\text { Branch of Science } \\
\text { and Principal subjects of Research } \\
\text { during temure of Scholarship }\end{array}$ & $\begin{array}{l}\text { Degrees and other dis- } \\
\text { tinctions obtainet } \\
\text { since appointment to } \\
\text { Scholarship }\end{array}$ & $\begin{array}{l}\text { Particulars of Scholar's subsequent career } \\
\text { as far a ascertainet? }\end{array}$ \\
\hline $\begin{array}{l}\text { 215. Joster, Glyn William Arnold, } \\
\text { B.Sc. } \\
\text { Nominated by Victoria University } \\
\text { of Manchester }\end{array}$ & $1904-6$ & $\begin{array}{l}\text { Technical High School, Karls. } \\
\text { ruho }\end{array}$ & $\begin{array}{l}\text { Physical Chemistry.-Tho action of the } \\
\text { silent eloctric dischargo upon chlorino } \\
\text { and the action of light upon potassium } \\
\text { fcrro-cyanide in aqueous solution }\end{array}$ & - & $\begin{array}{l}\text { 1906, Chcmist to Saltpetersäure Indus- } \\
\text { tric Gesellschaft, Innsbruck, Tyrol, } \\
\text { and since } 1907 \text { Chief Chemical Engi- } \\
\text { nccr for their various factories. }\end{array}$ \\
\hline $\begin{array}{l}\text { 210. Salway, Artlur H., B.Sc. } \\
\text { Nominutcd by Univcrsity Colloge, } \\
\text { Nottingham }\end{array}$ & $1904-6$ & University of Leipzig . & $\begin{array}{l}\text { Ghenistry-On the isomcrism cxhibi- } \\
\text { ted by pseudo-acids, etc. On a fow } \\
\text { nitro-conpounds, with eapecial con- } \\
\text { sideration of tho relation between } \\
\text { colour and constitution }\end{array}$ & $\begin{array}{l}\text { Pli.D. Lcipzig } \\
\qquad(1906)\end{array}$ & $\begin{array}{l}\text { Since } 1906 \text { in Research Laboratories } \\
\text { of Burroughs Wellcome \& Co., } \\
\text { Chemists, London. }\end{array}$ \\
\hline $\begin{array}{l}\text { 217. Caldwell, Kenneth Somerville, } \\
\text { B.Sc. } \\
\text { Nominated Gy University Collego } \\
\text { of North Wales, Bangor }\end{array}$ & $1901-6$ & University of Loipzig . & $\begin{array}{l}\text { Chemistry.-Elcctric conductivities in } \\
\text { pyridine solution. Influence of tem- } \\
\text { perature on tho electric conductivi- } \\
\text { tics of pyridine solutions. On the } \\
\text { migration of the ion } \mathrm{C}_{3} \mathrm{H}_{3} \mathrm{NH} \text { in } \\
\text { pyridine solution, the ions H and } \\
\mathrm{CH}^{\prime} \text { in aqucous solution. Indirect } \\
\text { proof of the cxistence of aci-nitro } \\
\text { products }\end{array}$ & $\begin{array}{l}\text { Ph.D. Loipzig } \\
\text { F.I.C. London }\end{array}$ & $\begin{array}{l}\text { Formerly Demonstrator in Chemistry, } \\
\text { St. Bartholomew's Hospital. Now } \\
\text { Professor of Chemistry, Patna Col- } \\
\text { lege, Bengal. }\end{array}$ \\
\hline $\begin{array}{l}\text { 218. Burton, Eli Franklin, B.A. } \\
\text { Nominated by University of } \\
\text { Toronto }\end{array}$ & $1904-6$ & $\begin{array}{l}\text { Ca vendish Laboratory, and the } \\
\text { University of Birmingham for } \\
\text { a short poriod }\end{array}$ & $\begin{array}{l}\text { Physics.-On the properties of clec- } \\
\text { trically propared colloidal solutions. } \\
\text { The actions of electrolytes on col- } \\
\text { loidal solutions. The susceptibility } \\
\text { of iron on colloidal solution! }\end{array}$ & $\begin{array}{l}\text { B.A. Cambridge } \\
\text { (1906) } \\
\text { Ph.D. Toronto } \\
(1910)\end{array}$ & $\begin{array}{l}\text { In 1906. appointed Senior Demonstrator } \\
\text { in 1'hysict, University of Toronto. } \\
\text { I warded 1909. a Special Dissertation } \\
\text { Prize by Emmanucl College, Cam- } \\
\text { bridge, for thesis on the Physical Pro- } \\
\text { pertieg of Colloidal solutions. }\end{array}$ \\
\hline $\begin{array}{l}\text { 219. Knight, Cyril Workmun, B.Sc. . } \\
\text { Nominated by Queen's University, } \\
\text { Kingston. Ontario }\end{array}$ & $1904-6$ & Columbia University, Now York & $\begin{array}{l}\text { Geology. - Notes on soinc deposits in } \\
\text { the Eastern Untario gold belt and } \\
\text { several other researches in gcology }\end{array}$ & - & $\begin{array}{l}\text { 1907, Assistant Provincial Geologist } \\
\text { of Ontario, Canada. }\end{array}$ \\
\hline
\end{tabular}


220. Ross, William Horace, M.Sc. Nominated by Dalhousse Univer sity, Halifax, Nova Scotia

221. Cumming, Aloxander Charles, B.Se Nominated by University of MIel bourne

222. Andrew, Arthur Robert, B.Sc. . Nominated by University of New Zealand

223. Logeman, Willem Hendrik, M.A. Nominated by South African College, Cape 'Town

224. Sibly, Thomas Franklin, B.Se. Vominated b!y University College, Bristol (now University of Bristol)
Johns Hopkins University and University of Chicago Therelation botween the radio-activity

University College, Dundeo; University of Breslau; University College, London

University of Birmingham.

Chemistry.-The affinity constants of tho study of strong electrolytes;

Geology.-The geology of the gold-

Physies. - The production of sceondary

University College, Bristol, and University of Birmingham of ultra-violet light. The relation between the radio-activity and the composition of thorium compounds. The specific radio-activity of uranium. The specific radio-activity of thorium and the variation of the activity with chemical treatment and with time. and the composition of thorium and uranium mincrals

Ph.D. Chicago (1907) amphotcrie electrolytes; methyl derivatives of anids ; on the electrocliemistry of lead, contributions to on the soureo of the radio-activity of the mineral malacone, a silicatc of zirconium bearing veins of Merionethshire rays by a-rays from polonium

Since 1907 Assoeiatc Chemist at Agricultural Experiment Station of Arizona, 'Iucson, U.S.A.

D.Se. Melbourno

1907. Lecturer and Demonstrator in Chomistry at Birkbeck College, Londoul 1908, Lecturer and Second Assistant in Chemistry Department, University of Edinburgh.

M.Sc. Birmingham (1906)

F.(G.S. (1906)

Assoc.I.M.M.

1906, appointed on the staff of the Imperial Institutc to conduet a Geological Surrey in British Central Afrier (Nyasaland). 1910, uppointed to a City syndicate.

D.Se. London (1908)

cology.-Carboniferous rocks in Mid lands and in Mendip Hills, Somerset. Investigation of the faunal suecession in the Lowcr Carboniferous rocks of these areas
D.Se. Bristol

(1910)
1908, Lecturer and Demonstrator in Geology ; 1909, Lceturer in charge College, London. 
LIST OF SCIENCE RESEARCH SCHOLARS APPOINTED BETWEEN THE YEARS 1891 AND 1910-continued.

\begin{tabular}{|c|c|c|c|}
\hline Name of Scholrs & $\begin{array}{l}\text { Ycars of tenare } \\
\text { of Scholarship }\end{array}$ & Places of study during Scholarship & $\begin{array}{l}\text { Branch of Science } \\
\text { and Principal subjects of Research } \\
\text { during tenure of Scholarslip }\end{array}$ \\
\hline $\begin{array}{l}\text { 225. Smitl, Stanley Parkor, B.Se. } \\
\text { Nominated by Armstrong Col- } \\
\text { lege, Newcrstle-upon-'Tyne }\end{array}$ & $\begin{array}{l}\text { Bursar } \\
(1901-5) \\
\text { Scholar } \\
(1905-7)\end{array}$ & $\begin{array}{l}\text { Armstrong College, and Electro- } \\
\text { technisches Institut, Karls. } \\
\text { ruhe }\end{array}$ & $\begin{array}{l}\text { Electrieal Enginecring.-Determination } \\
\text { of flux distribntion in eommutating } \\
\text { pole maehines. Mcasurement of } \\
\text { iron losses in pole shoes due to } \\
\text { armature teeth ; ealculation of cha- } \\
\text { racteristie curves of single-phaseseries } \\
\text { commutator motors; investigation } \\
\text { of applieation of no-load and short- } \\
\text { circuit diagram to induetion motors }\end{array}$ \\
\hline $\begin{array}{l}\text { 226. Carnwath, Thomas, B.A., M.B., } \\
\text { B.Ch. } \\
\text { Nominated by Queen's Collego, } \\
\text { Belfast (now Queen's Univer- } \\
\text { sity of Bolfast) }\end{array}$ & $\begin{array}{c}1904-5 \\
(\text { Bursar }) \\
1905-7 \\
\text { (Scholar) }\end{array}$ & $\begin{array}{cl}\text { Queen's } & \text { College, Belfast; Hy- } \\
\text { gienic } & \text { Institute, Hamburg; } \\
\text { and } & \text { Reieligesundlieitsant, } \\
\text { Berlin } & \end{array}$ & $\begin{array}{l}\text { Bacteriology and Chemistry.-The } \\
\text { relation of baeterial flora of shell- } \\
\text { fish to sewage pollution of surround- } \\
\text { ing watcr b bacteriologieal survey } \\
\text { of Belfast Lough; the dispcrsal of } \\
\text { nitrogen by baetoria ; absorption in } \\
\text { bncteria beds ; denitrifieation; inter- } \\
\text { mittent filtration; diphtheria in fowls }\end{array}$ \\
\hline $\begin{array}{l}\text { 227. Innes, Peter David, M.A., B.Sc. . } \\
\text { Nominuted by University of Edin- } \\
\text { burgh }\end{array}$ & $190 \overline{3}-8$ & Cavendisl Laboratory & $\begin{array}{l}\text { Physics. - The veloeity of the kathode } \\
\text { particles omitted by various metals } \\
\text { under the influence of Röntgen rays } \\
\text { and its bearing on the theory of } \\
\text { atomie disintegration. The size of } \\
\text { tho positive ions in flames which do } \\
\text { not eontain hydrogen }\end{array}$ \\
\hline $\begin{array}{l}\text { 228. Miller, John, Mr.A. . } \\
\text { Nominated by University of Glas- } \\
\text { gow }\end{array}$ & $190 \check{5}-7$ & $\begin{array}{l}\text { University of Göttingen and } \\
\text { University of Glasgow }\end{array}$ & $\begin{array}{l}\text { Pliysies.-On the eonstant of elastieity } \\
\text { of alloys of various motals, with } \\
\text { special referenee to the inner friction } \\
\text { of the samo; the effects of tem- } \\
\text { perature and of overstrain on tho } \\
\text { viscosity of metallic wires }\end{array}$ \\
\hline
\end{tabular}

\begin{tabular}{|c|c|}
\hline $\begin{array}{l}\text { Degrees and other dis- } \\
\text { tinctions obtained } \\
\text { since nppointment to } \\
\text { Scholarship }\end{array}$ & $\begin{array}{c}\text { Particulars of Scholar's subsequent carcer } \\
\text { as far th arcertained }\end{array}$ \\
\hline $\begin{array}{l}\text { A.M.I.E.E. } \\
\text { (1909) } \\
\text { M.Sc. (1910) }\end{array}$ & $\begin{array}{l}\text { 1907, engaged in teehnieal design of } \\
\text { alteriating-eurrent maelinery and } \\
\text { in spccial work at Siemens Bros.' } \\
\text { Dynamo Works, Stafford. Also Lee- } \\
\text { turer inAdvaneed Eleetrical Engineer- } \\
\text { ing at Stafiord Tcehnical Sehool. } \\
1909 \text {, appointed Head Designer at } \\
\text { Gencral Eleetrie Co., Witton, Bir- } \\
\text { mingham. }\end{array}$ \\
\hline
\end{tabular}

Diploma of Public Henlth, Cambridge $(1906)$

B.A. Cambridge (1907),

D.sc. Edin burgh (1909)

B.Sc.

Glasgow
1907, Assistant Physieian, Infeetions Diseases Hospital, Salford. 1908 Assistant Medical Officer of Health, Mrnchestcr. 1910, Medical Inspector H.MI. Loeal Government Bonrd.

1907, appointed Examincr in Mathematies and Dynamies for Preliminary Examination, and Representative of the University of St. Andrews on the Joint Board of the Universities of Scotland. 1908, Assistant Professor of Physies, and 1910, Heal of Physies Department, Heriot-Watt College, Edinburgh. Also appointed, 1910, External Examiner for four years, in subjeets of Pure and Applied Mathematies for ordinary and hollours degrees in Arts and Seienee, University of Edinburgh.

Formerly Mathematieal and Seience Master at Rose's Acndemical Institution, Nairn. Now Mathematieal Master, Stonehaven Mrackie Academy. 
229. Johnston, John, B.Sc. :

Nominaled by University of St. Andrews

230. Imms, Augustus Danicl, B.Sc. Nominaled by Univcrsity of Birmingham

231. Gwyer, Alfred George Cooper, B.Sc ominaled by Univcrsity Collegc, Bristol (now University of Bristol)

232. Zortman, Israel Hyman, B.Sc. Nominaled by University of Lceds

233. Wall, Thomas Frederick, B.Sc., B.Eng.

Nominated by University of Liverpoo
Physical Chemistry. - Tho dissociation

$1905-7$

$1905-7$

$1905-7$
Morphological Laboratory, University of Cambridgo

University of Göttingen . . Chemistry.-The study of aluminium

University of Leipzig .

Chemistry.-The relation between colour and constitution of diketoly. drindone derivatives

Zoology.-On the life-histories of the ox warble flics-Hypoderma bovis (de Geer) and $H$. lineala (Villiers). the structure and biology of the larva and pupa of Anopheles maculipennis

$$
\text { alloys }
$$

Electrotcchnisches Institut, Karlsruhe

lectrical Engincering.-An investigation into tho iron losses in asynpressures of some metallic hy. droxides and carbonates (1908)

A. Cambridgc (1907),

D.Sc. Birmingham (1907),

Fcllow of Allah-

abad University (1909)

Ph.D. Göttingen Ph.D. Lcipzig
(1907) chronous machines. A ncw method of separating the iron losses in asynchronous maclines. The reluctance of the air-gap dynamo machines. Detcrmination of losses in pole shocs due to armature tceth

M.Sc. Victoria (1906),

M.Eng. Livcrpoo $(1908)$,

A.M.I.C.E

(1909).

A.M.I.E.E.

(1909)
1907-S, Rosearch Associatc of the Rcscarch Laboratory of Physical Chemistry, Massachusetts Instituto of Technology, Boston, U.S.A. Since 1908 on staft of Gcophysical I tory, Carncgic Institution of Wash iugton, D.C. chraged in indopcindent rescarch.

Since 1907 Professor of Biology, Muir Central College, University of Allahabad, India.

1908-9, cllgaged in scicntific rescarch in Sir William Ramsay's Laboraory, University College. Loudon. Norv spccialising in Netallurey. Fcllow of the Chemical Socicty and of the Gorman Chemical Socioty. of the German Chemical society. fictols.

1908, Chcmist to Harker Firc Extinguishcr \& Fumigator Co., Ltd.,
London. 1910, Chemist to RadiantHcating, Ltdl., Carlton Works, Arm lcy, Lccds.
1907-1909, cugaged in special tcchnical work with Sicmens Bros., Stafford. Also Special Extomal Tocturer to Univority of Iiverpool and Spocial Universily of Liverpol and spocial Lecturer to Bing School. 1909-10, Assistant LecEn and Engineering, and 1910, Lecture on Electrical Engineering, Uni versity of Birmingliam. 
LIST OF SCIENCE RESEARCH SCHOLARS APPOINTED BETWEEN PHE YEARS 1891 AND 1910 -continued.

\begin{tabular}{|c|c|c|c|c|c|}
\hline Name of Scholar & $\begin{array}{l}\text { Ycars of tenure of } \\
\text { Scholarship }\end{array}$ & Places of study during Scliolarship & $\begin{array}{l}\text { Branch of Science } \\
\text { aud Principal subjects of Rescarch } \\
\text { during tenure of Scholarship }\end{array}$ & $\begin{array}{l}\text { Degrces and other dis- } \\
\text { tinctions obtained } \\
\text { sillcc appointment to } \\
\text { Scholarslip }\end{array}$ & $\begin{array}{l}\text { Particulars of Scliolnr's subsequent eareer } \\
\text { as far as ascertained }\end{array}$ \\
\hline $\begin{array}{l}\text { 234. Smith, Winifred, B.Se. } \\
\text { Nominated by University Collego, } \\
\text { Iondon }\end{array}$ & $1905-7$ & $\begin{array}{l}\text { Royal College of Science, Lon- } \\
\text { don }\end{array}$ & $\begin{array}{l}\text { Botany.-On the anatomy, embryo- } \\
\text { geny, and physiology of the natural } \\
\text { order Sapotacee }\end{array}$ & $\begin{array}{c}\text { Fellow of the } \\
\text { Limnean Soeiety } \\
(1908)\end{array}$ & $\begin{array}{l}\text { 1907-9, lecturing in Botany and } \\
\text { Nature Studies, and pursuing at } \\
\text { Imperial College of Seience and } \\
\text { technology her work on the Sapo- } \\
\text { tacer and on Funtumia elastica, a } \\
\text { recently cultivated rubber plant. } \\
\text { Still engaged in research. }\end{array}$ \\
\hline $\begin{array}{l}\text { 235. Rimmer, Travis, B.Sc. } \\
\text { Nominated by Vietoria University } \\
\text { of Manchester }\end{array}$ & $1905-7$ & $\begin{array}{l}\text { Meteorologieal Institute of the } \\
\text { University of Vienna and at } \\
\text { the Observatories of Somn- } \\
\text { bliek and Kew }\end{array}$ & $\begin{array}{l}\text { Meteorology.-Investigations in atmo- } \\
\text { spherie electricity and measurements } \\
\text { in solar and terrestrial radiation }\end{array}$ & $\begin{array}{l}\text { M.Sc. Vietoria } \\
(1907)\end{array}$ & $\begin{array}{l}\text { 1908. Resident Observer in charge of } \\
\text { Howard Estate Meteorologieal Ob- } \\
\text { servatory, University of Manchester. } \\
\text { 1908-9, Assistant, and } 1909 \text {. Aeting } \\
\text { Offiecr-in-Charge, Government Sur- } \\
\text { rey, Fiji. }\end{array}$ \\
\hline $\begin{array}{l}\text { 236. Lebour, Marie Vietoire . } \\
\text { Numinated by Armstrong College, } \\
\text { Neweastle-upon-'Tyne }\end{array}$ & $1905-8$ & Armstrong College $. \quad . \quad$. & $\begin{array}{l}\text { Zoology. - Investigation of the mussel } \\
\text { beds of Northumberland. Investiga- } \\
\text { tion of the trematode fauna of } \\
\text { Northumberland with speeial refer- } \\
\text { oneo to life-listories }\end{array}$ & M.Se. Durham & $\begin{array}{l}\text { 1908, Junior Demonstrator, and } 1910 \text {, } \\
\text { Assistant Lecturcr and Demonstrator } \\
\text { in Zoology, Lecls University. }\end{array}$ \\
\hline $\begin{array}{l}\text { 237. Garrett, Charles A. B., B.Se. } \\
\text { Nominated by University College, } \\
\text { Nottingham }\end{array}$ & $190 \tilde{s}-7$ & Cavendish Laboratory & $\begin{array}{l}\text { Physics.-The velocity of gaseons ions } \\
\text { under an elcetric field in air and in } \\
\text { mixtures of air and hydlogen }\end{array}$ & - & $\begin{array}{l}\text { Head of Department of Physics, } \\
\text { Blnckbum Peelmienl Institute. }\end{array}$ \\
\hline $\begin{array}{l}\text { 238. Gallagher, William John, B.A. } \\
\text { Nominated by Queen's College, } \\
\text { Cork (now University College, } \\
\text { Cork) }\end{array}$ & $\begin{array}{l}1905-6 \\
\text { (Eightcen } \\
\text { months) }\end{array}$ & $\begin{array}{l}\text { Königl. Preuss. Forstakademic, } \\
\text { Mü̈nden, Hanover }\end{array}$ & $\begin{array}{l}\text { Botany.-On the root anatomy of the } \\
\text { Meliacex and the Cupuliferæ }\end{array}$ & $\begin{array}{l}\text { M.A. Royal Uni. } \\
\text { versity of Treeland } \\
\text { (1n06) }\end{array}$ & $\begin{array}{l}\text { 1906, resigned Seholarship on being } \\
\text { appointed Government Myeologist, } \\
\text { Department of Agrieulture, Fede- } \\
\text { lated Malay States. 1909, Director of } \\
\text { Agriculture, Federated Malay States. }\end{array}$ \\
\hline $\begin{array}{l}\text { 239. Clirke, Rosalind, B.A. ' } \\
\text { Nominated by Queen's College, } \\
\text { Galway (now University Col- } \\
\text { lege, Galway) }\end{array}$ & $1905-7$ & University of Bonn . . . & $\begin{array}{l}\text { Chemistry--The determination of the } \\
\text { constitution of the compound pro- } \\
\text { duced by the action of ammonia on } \\
\text { itreonic acid. The diseovery of an } \\
\text { analogy between the phenyl ester } \\
\text { of mesaconie neid and aromatic } \\
\text { esters of fumaric aeid }\end{array}$ & - & $\begin{array}{l}\text { On expiration of Seholarship eontinued } \\
\text { studies in Chemical and Physieal } \\
\text { Taboratories, Queen's College, Gal. } \\
\text { way. 1908. Seieneo Mistress, High } \\
\text { Sehool for Girls and Roehelle School, } \\
\text { Cork. }\end{array}$ \\
\hline
\end{tabular}


240. Johnson, F. M. G., B.Sc. • . Nominaled by MeGill Univorsity, Montreal

241. MaeDougall, Frank Henry, M.A. Nominated by Queen's University, Kingston, Ontario

242. Laby, Thomas Howell Nominaled by University of Sydney

43. Kleeman, Richard Danicl, B.Sc. . Nominaled by University of Adelaide
University College, London; University of Breshau

$1905-7$

$1905-8$

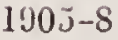

Cavendish Laboratory

Cavendish Laboratory
Chomistry.-Elcetrode potentials in liq̧uid ammonia. Measurement of dissociation and sublimation pressures

University of Leipzig. - . Chemistry.-On the kincties of the reaction between ehloric and hydrochlorie acids

Physics.-On a relation between the velocity and volume of tho ions of certain organie acids and bases. A relation between tho velocity and volume of organie ions in aqueous solutions. The total ionisation of various gases by the a-rays of uranium. Gaseous ionisation and pressurc. A recalculation of the vapour pressure of mercury. The supcrsaturation and nuclear condensation of eertain organic vapours Ithy made by $\alpha, \beta, \gamma$, and $x$ rays. On the ionisation of various gases by $\alpha$, $\beta$, and $\gamma$ rays. On tho secondary cathocle rays omitted by substances when cxposed to tho $\gamma$-rays. On the different kinds of $\gamma$-rays and tho sceondary rays which they produee. On the voloeity of the cathode riass ejeeted from substanees exposed to tho $\gamma$-rays of radium
M.Sc. MeGill (1905)

A.I.C. (1906),

Ph.D. Bresla

I.C. (1909)

Ph.D. Leipzig

B.A. Cambridge (1907)

Awrded doule Studentship of Royal Socicty for (wo year

(July 1907)

B.A. Cambridge (1907),

D.Se. Adclaide (1908)
Lecturer in Chenistry, McGill University, Montreal.

1907, Instructor of Chemistry, and 1909, Assistant Professor of Chemis. try, Agricultural and Mrchanical College of Texas.

Awarded the Sudbury Hardyman Prize and a Research Studentship by Eimmanucl College of fiso for 1908-9 in eonsideration of his work on the supersaturation and nuclen condensation of certan organic vipours, undertaken duning his tenure of the Commissioners' Scholarship. 1909, Professor of Physics, Victoria College, Nefhngton, New Zealiund.

Awarded, 1908, by Emmanuel College, Cambridge, a Seience Researeh Scholarship, two tenms of which wero spent at Cambridge, the third under rofessor Rutherford at Nanehester. Obtained also the Sudbury Hardy man Prizo of Emmanuel College, for a dissertation on ionisation. Awarded, 1909, Mackinnon Studentship of the Royal Soeiety. Summer and part of first terin spent at leeds University under Professor Bragg: rest of year at Cambridge, time being divided between experimental 1. divide bavendish I aboratory, and theorotical research on the fores theorctioal rescarch on the form atraetion botwcen molocilo and the effect thoy produce. 1910, obtained renewal of Mackinnon Studentship for another year. 
IIST OF SCIENCE RESEARCH SCHOLARS APPOINTED BETWEEN THE YEARS 1891 AND 1910-continued.

\begin{tabular}{|c|c|c|c|c|c|}
\hline Same of Scholar & $\begin{array}{l}\text { Years of tenure } \\
\text { of Scholarslipg }\end{array}$ & Places of study during Scholarship & $\begin{array}{l}\text { Branch of Science } \\
\text { and Principal subjects of Research } \\
\text { during tenure of Scholarship }\end{array}$ & $\begin{array}{l}\text { Degrees and other dis- } \\
\text { tinctions obtained } \\
\text { since appointment to } \\
\text { Scholarship }\end{array}$ & $\begin{array}{l}\text { Particulars of Scholar's subsequent career } \\
\text { as far as ascertained }\end{array}$ \\
\hline $\begin{array}{l}\text { 244. Picton, Norman, B.Sc. } \\
\text { Nominated by University Collegc } \\
\text { of Wales, Aberystwyth }\end{array}$ & $\begin{array}{l}\text { Bursar } \\
(1905-6) \\
\text { Seholal } \\
(1906-8)\end{array}$ & $\begin{array}{l}\text { University College, Abcryst- } \\
\text { wyth, and University of Leip- } \\
\text { zig }\end{array}$ & $\begin{array}{l}\text { Organic Chemistry.-On the influence } \\
\text { of substitucnts in the trinitrobenzine } \\
\text { molccule on the formation of ad- } \\
\text { ditive compounds with arylamines. } \\
\text { The investigation of eertain coloured } \\
\text { salts of nitro-bodies }\end{array}$ & Ph.D. Leipzig & $\begin{array}{l}\text { 1909, Chemical Expert to C. W. Martin } \\
\text { \& Sons, Furriers, Bermondsey. }\end{array}$ \\
\hline $\begin{array}{l}\text { 245. Swinden, Thomas } \\
\text { Nominated by University of Shef- } \\
\text { field }\end{array}$ & $\begin{array}{l}\text { Bursar } \\
(1905-6) \\
\text { Scholar } \\
(1906-8)\end{array}$ & $\begin{array}{l}\text { Universities of Sheffeld, Stock- } \\
\text { holm, and Upsala }\end{array}$ & $\begin{array}{l}\text { Metallurgy.-The influcnce of carbon on } \\
\text { steels containing a fixed tungsten } \\
\text { content }(3 \%) \text {. Investigation of me- } \\
\text { chanical, chemical, microscopical, } \\
\text { thermal, magnetic, and electrical } \\
\text { properties. Researches on magnetic } \\
\text { fumctions and their mutual rolations. } \\
\text { On methods of measuring high tem- } \\
\text { peratures }\end{array}$ & $\begin{array}{l}\text { B.Met. Sheffield } \\
\text { (1908) }\end{array}$ & $\begin{array}{l}\text { In } 1908 \text { joined Mr. Perey Longmuir as } \\
\text { Consulting Metallurgist and Ana- } \\
\text { lytieal Chemist. 1909. Carnegie Scho- } \\
\text { lar. 1910, Appointed Chief Assist- } \\
\text { ant Metallurgist, Messrs. Samuel Fox } \\
\text { \& Co., Ltd., Stockbridge Works, near } \\
\text { Sheffield. }\end{array}$ \\
\hline $\begin{array}{l}\text { 246. Cameron, Alexander Thomas, } \\
\text { M.A., B.Sc. } \\
\text { Nominated by University of Edin- } \\
\text { burgh }\end{array}$ & $1906-9$ & $\begin{array}{l}\text { University College, London, } \\
\text { and Technische Hochsehule, } \\
\text { Karlsruhe }\end{array}$ & $\begin{array}{l}\text { Chemistry. - The chemical aetion of } \\
\text { radium emanation. The electro- } \\
\text { motive forecs produeed by dilute } \\
\text { solutions streaming through eapillary } \\
\text { tubes. }\end{array}$ & - & $\begin{array}{l}\text { Appointed, December 1909, Lecturer } \\
\text { in Physiological Chemistry, Univer- } \\
\text { sity of Manitoba, Winnipeg. }\end{array}$ \\
\hline $\begin{array}{l}\text { 247. Jack, Robert, Mr.A., B.Sc. } \\
\text { Nominated by University of Glas- } \\
\text { gow }\end{array}$ & $1906-9$ & $\begin{array}{l}\text { Univcrsities of Göttingen and } \\
\text { Paris }\end{array}$ & Physics.-On the Zeeman effect. & $\begin{array}{l}\text { Ph.D. Göttingen } \\
\text { D.Se. Glasgow }\end{array}$ & $\begin{array}{l}\text { Appointed, September 1909, Leeturer } \\
\text { in Physics, Queen's University of } \\
\text { Belfast. }\end{array}$ \\
\hline $\begin{array}{l}\text { 248. Barrow, Fred, M.Sc. } \\
\text { Nominated by University of Bir- } \\
\text { mingham }\end{array}$ & $1906-8$ & University of Strassburg & $\begin{array}{l}\text { Chemistry. - The action of alcoholic } \\
\text { potash, etc., on } p \text {-nitrobenzal chloride, } \\
\text { and the condensation of } p \text {-nitro- } \\
\text { benzyl, and p-nitrobcnzal ehloride } \\
\text { and bromide with aldehydes }\end{array}$ & Ph.D. Strassburg & $\begin{array}{l}\text { Assistant Leeturer and Demonstrator } \\
\text { in Chemistry, Birkbeck College, } \\
\text { London. }\end{array}$ \\
\hline $\begin{array}{l}\text { 249. Burt, Frank Playfair, B.Sc. . } \\
\text { Nominated by University College, } \\
\text { Bristol (now University of } \\
\text { Bristol) }\end{array}$ & $1906-8$ & $\begin{array}{l}\text { University College, Bristol, and } \\
\text { University Collegc, London }\end{array}$ & $\begin{array}{l}\text { Chemistry.- The atomie weight of } \\
\text { chlorine, based on an experi- } \\
\text { mental deternination of the density } \\
\text { of hydrogen chlorido and on the } \\
\text { volumetric analysis of hydrogen } \\
\text { chlorido }\end{array}$ & - & $\begin{array}{l}\text { Still engaged in Chemical Research in } \\
\text { University College, London. }\end{array}$ \\
\hline
\end{tabular}


250. Armes, Henry Percy, B.Sc. Nominated by University of Leeds

251. Barker, Jonathan Tong, B.Sc. Nominaled by University of Liverpool

252. Sheppard, Samuel Edward, B.Sc Vominated by University Colloge, London

253. Kay, Francis William, B.Sc. Vominated by Victoria University of Manehestor

254. Wood, George Curry, B.Sc. Nominated by Armstrong Collegc, Noweastle-upon-'Tyne

255. Tomlinsan, Gcorge Arthur, B.Sc. Nominated by University Colloge Nottingham

256. Davies, John Hughes, B.Sc. Nominaled by University Colloge of South Wales and Wonmouth shire, Cardiff
University of Strassburg . .

$906-8$

University of Borlin

Physical Instituto of the University of Mrrburg ; Physical Research Laboratory and Physiological Laboratory of the University of Paris

$1906-9$

Universities of Bcrlin and Geneva

C

mistry. - l'olypoptides from $\beta$-amido acids and other resoarches in organic chemistry, particularly on the alkaloids

$1906-8$

Eidgen. Polytechnische Schule, Zürich

Pliysics.-The clectro-motive force of concentration cells

$1906-8$

Engineering Laboratory, University of Cambridge

$1906-8$

Physical Chemistry.-Investigation of the vapour pressures of toluene, benzene, and naphth

Chomistry. - Investigations on tho theory of sensitising photographic plates with dyestuffs. The optical and sensitising properties of the isocyaninc dyes. On colloidal dyestuffis

Engineering.--On the rate of combustion of explosivo mixtures of coal gas and air. On the specific heat of metals at high temperatures
University of Leipzigy . . Physical Chemistry.--The docomposition and synthesis of ammonia under the influence of the silent discharge
M.Se. Victoria Ph.D. Berlin

M.Sc. Durham (1908)

Ph.D. Bcrlin (1908) (1910)

D.Se. London (19118)

Ph. D.

Leipzig (190s
M.Sc. Liverpool ecturer in Chemistry, Univorsity of Mlanitoba.

1909-10. engaged in research at Muspratt Laboratory of Physical Chcmistry. University of Liverpool. Since April, 1910, las been in the employ of Messrs. Brunner, Mond \& Co., Ltsl.

Formerly engaged in research at University College. London, muder Sir William Ramsay. Now engaged as Research Chemist with Mcssrs. Wratten and Wainwright, Photographic Plate Mimufacturcrs, Croydon, Surrey.

Demonstrator, School of Chcmistry, University of Geneva.

Studied for cliploma in theory and practice of teaching, Armstrong College, Newcustle-upon-Tync. Now Scienec Master in Technical Institute, Consett, Co. Durham. Lecturer on Physies in Technieal Department.

1908-10, Demonstrator, Engincering Laboratories. Cambridge. 1910, Experimentalist for Messrs. Kolvin and James White, Glasgow.

1908, University Assistant at the Physikalisch - Chomisches Institut, University of Leipzig. 1909-10, Lecturer in Chemistry and Physics at the Training College, Carmarthen. 1910, Vicc-Principal of St. Peter's Training Collcge for Teachers, Peterborough. 
LIST OF SCIENCE RESEARCH SCHOLARS APPOINTED BETWEEN THE YEARS 1891 AND 1910-continued.

\begin{tabular}{|c|c|c|c|c|c|}
\hline Name of Scholar & $\begin{array}{c}\text { Years of tenure of } \\
\text { Scholarship }\end{array}$ & Places of studs during Scholarship & $\begin{array}{l}\text { Branch of Science } \\
\text { and Principal subjects of Research } \\
\text { dutiny tenure of Scholarship }\end{array}$ & $\begin{array}{l}\text { Degrees and other dis- } \\
\text { tinctions obtainell } \\
\text { since appointment to } \\
\text { Scholarship }\end{array}$ & $\begin{array}{l}\text { Particulars of Scholar's snbsequent career } \\
\text { us far as ascertained }\end{array}$ \\
\hline $\begin{array}{l}\text { 257. Hedley Edgar Perey } \\
\text { Nominated by Royal College of } \\
\text { Science for Ireland }\end{array}$ & $1906-9$ & $\begin{array}{l}\text { University of Leipzig and Federal } \\
\text { Polytechnie, Ziirieh }\end{array}$ & $\begin{array}{l}\text { Chemistry.--On polynitro-bodies and } \\
\text { polynitro-compounds. The study of } \\
\text { the alkaloids }\end{array}$ & Ph.D. Leipzig & $\begin{array}{l}\text { Leeturer and Demonstrator in Chemis- } \\
\text { try, University of Birmingham. At } \\
\text { present engaged in translating "New } \\
\text { Ideas on Inorganic Chemistry," from } \\
\text { the Cierman work of Professor A. } \\
\text { Werner. }\end{array}$ \\
\hline $\begin{array}{l}\text { 258. McKee, James Lyttle } \\
\text { Nominated by Queen's College, } \\
\text { Belfast (now Queen's Univer- } \\
\text { sity of Belfast) }\end{array}$ & $1906-8$ & University of Freiburg, Breisgau & $\begin{array}{l}\text { Chemistry.--The aetion of sulphuret- } \\
\text { ted lyydrogen on hydro-aromatic and } \\
\text { certain aliphatic ketones }\end{array}$ & Ph.D. Freiburg & $\begin{array}{l}\text { Until January, 1910, Seienee Master, } \\
\text { Market Bosworth Grammar School. } \\
\text { Since that date, Demonstrator in } \\
\text { Chemistry, University College, Cork. }\end{array}$ \\
\hline $\begin{array}{l}\text { 259. Clark. Robert Harvey, B.A.. } \\
\text { Nominated by IJniversity of } \\
\text { Toronto }\end{array}$ & $1906-9$ & University of Leipzig & $\begin{array}{l}\text { Chemistry.-The relation between the } \\
\text { eolour fluorescence of organie eom- } \\
\text { pounds and their constitution }\end{array}$ & Ph.D. Leipzig & $\begin{array}{l}\text { Assistant Professor of Chemistry, Clark } \\
\text { College, and Lecturor in Clremistry, } \\
\text { Ulark University, Woreester, Mrassa- } \\
\text { chusctts. }\end{array}$ \\
\hline $\begin{array}{l}\text { 260. MacKay, George Moir Johnstone, } \\
\text { B.A. } \\
\text { Nominated by Dalhousie Univer- } \\
\text { sity, Halifax }\end{array}$ & $1906-8$ & $\begin{array}{l}\text { Massaehusctts Institute of Tech- } \\
\text { nology }\end{array}$ & $\begin{array}{l}\text { Chemical Physies.-Equilibria in aque- } \\
\text { ours solutions eontaining copper and } \\
\text { iodine. 'Transference measurements } \\
\text { in aqueous solutions eontaining the } \\
\text { chloride and sulphate of potassium }\end{array}$ & $\begin{array}{l}\text { M.Sc. Massaehu- } \\
\text { setts (1908) }\end{array}$ & $\begin{array}{l}\text { 1908, Instructor in Chemistry. Unirer- } \\
\text { sity of Dalhousic. 1909. Cliemist } \\
\text { to Sydney Cement Company, Syd- } \\
\text { ney, Nova Scotia. 1910, Chemist } \\
\text { to Colloseïs Cement Co., Buffalo, } \\
\text { N.Y. }\end{array}$ \\
\hline $\begin{array}{l}\text { 261. Baldwin, James Mrson, M.A., B.Sc. } \\
\text { Iominated by University of Mel- } \\
\text { bourne }\end{array}$ & $1906-8$ & $\begin{array}{l}\text { Royal Observatory, Cape Town, } \\
\text { and Astrophysieal Observa- } \\
\text { tory, Potsdan }\end{array}$ & $\begin{array}{l}\text { Astrophysics.-The orbit of the a-Cen- } \\
\text { tauri ; and the parallax determined } \\
\text { spectro-graplieally. Photometric } \\
\text { observations of planets and variable } \\
\text { stars }\end{array}$ & - & $\begin{array}{l}\text { 1908, appointed Chief Assistant in } \\
\text { the Melbourne Observatory. }\end{array}$ \\
\hline $\begin{array}{l}\text { 262. Denham, Henry George, M.A.... M.Se. } \\
\text { Nominated by University of. New } \\
\text { Zealand }\end{array}$ & $1906-9$ & $\begin{array}{l}\text { Universitics of Liverpool and } \\
\text { Heidelberg }\end{array}$ & $\begin{array}{l}\text { Physical Chemistry.-The hydrolysis } \\
\text { of heavy metal salts and research in } \\
\text { other branches of physical chemistry. }\end{array}$ & $\begin{array}{l}\text { D.Sc. Liverpool } \\
\text { Ph.D. } \\
\text { Heidelberg }\end{array}$ & $\begin{array}{l}\text { At present engaged in research work at } \\
\text { Canterbury College, Clristchurcli, } \\
\text { New Zealand. }\end{array}$ \\
\hline $\begin{array}{l}\text { 263. Millar, William Somerville, M.A., } \\
\text { B.Sc. } \\
\text { Nominated by University of Edin- } \\
\text { burgh }\end{array}$ & $1907-9$ & $\begin{array}{l}\text { University of Heidelberg and } \\
\text { University College, London }\end{array}$ & $\begin{array}{l}\text { Physieal Chemistry. - The antieata- } \\
\text { lytie effeet of water in the cliemieal } \\
\text { kinetics of cliazoacetic ester. Mole- } \\
\text { eular volumes of rare gases }\end{array}$ & $\begin{array}{l}\text { Ph.D. } \\
\text { Heidelberg }\end{array}$ & $\begin{array}{l}\text { Engaged in eommercial reserreh on the } \\
\text { treatment of } n \text { olfram, tungstie aeid. } \\
\text { and tungsten motal. }\end{array}$ \\
\hline
\end{tabular}


264. Thomson, Darid, M.A., B.Se. . Nominated by University of Glasgow

265. Weir, John, M.A., B.Se.

Nominated by University of St. Andrews

$1907-1910$

$907-9$

266. Watson, Ernest Ansley, B.Se. Nominated by University of Birmingham

267. Usher, Franeis Lawry, B.Se. Nominated by University of Bris-

268. Hodlsman, ILenry James, B.Se. Nominated by University of Leeds

26i9. Dakin, William John, M.Se Nominuted by University of Liverpool

$1907-1910$

$1907-9$
Organic Chemistry. - On the relation of optical activity to elıemical constitu-

Ph.D.

Göttingen tíon

Universities lof Würzburg and Cambridge benzoyl-aspartie aeid. Camphoric aeid derivatives

University of Liverpool

Engineering.-Investigation of tho cleetrie strength of eompressed air, due to brush disehargo

University of Praguo and University College, London

Technical High Seloool, Karlsruhe, and MI. Le Chatelier's Laboratory, Sorbonne, Paris

University of Kiel, Biologieal Station at Heligoland, Naples, P'ort Erin and Liverpool

Wïr\%burg

Physieal Chenistry.-On the combination of nitrie oxide with iron salts. On the influenee of non-eleetrolytes on the solubility of gases in water. On the aetion of radium enanation on ammonia and on mixtures of nitrogen and hydrogen, ste. On the aetion of radium cnlanation on clements of the earbon group

Physieal Chemistry.- Study of eombustion and ehemistry of ligh temperatures

Marine Biology.-Osmotic pressure of the blood of fishes. On the eeonomie molluse Peeten (the seallop). 'The rganie Chemistry.- Some derivates of etc Losses off transmission lines

Demonstrator in Senior Chemistry Departing

Birmingham question of the food of Copepoda. Methods of Plankton researeh. Filtration co-efficients of Plankton nets. The eye of Pceten
Ph.D.

M.Se.

Eleeted Carnegie Fellow, 1910.

In eharge of the technieal work of Iorris \& Lister, Limited, Eleetrieal Engineers, Coventry.

July 1910, appointed to Chair of Chemistry in the Central College, Bangalore, India. Still engaged in researeh work.

1909, Demonstrator and Assistant Lecturer in 'Zoology, Queen's Uni versity, Belfast. 1910, Demonstrator and Assistant Leeturer on Zoology, University of Liverpool.

ngaged in technieal research work for the British Cyanide Company, Oldbury. 
LIST OF SCIENCE RESEARCH SCHOLARS APPOINTED BETWLEN THE YEARS 1891 AND 1910-contimud.

\begin{tabular}{|c|c|c|c|c|c|}
\hline Name of Scholar & $\begin{array}{l}\text { Years of tenure of } \\
\text { Scholarslrip }\end{array}$ & Places of study during Scholarship & $\begin{array}{l}\text { Branch of Science } \\
\text { and Principal ibjects of Rescarch } \\
\text { during tenure of Scholarship }\end{array}$ & $\begin{array}{l}\text { Degrees and other dis. } \\
\text { tinctions obtained } \\
\text { sinee appointment to } \\
\text { Scliolurship }\end{array}$ & $\begin{array}{l}\text { Particulars of Soholar's subsequent career } \\
\text { as far as ascertained }\end{array}$ \\
\hline $\begin{array}{l}\text { 270. Netenlfe, Edward Parr, B.Se. } \\
\text { Nominated by University College, } \\
\text { London }\end{array}$ & $1907-8$ & $\begin{array}{l}\text { Cavendish Laboratory, Cam- } \\
\text { bridge }\end{array}$ & Physies.-Ionisation in various gases & - & $\begin{array}{l}\text { Resigned Seholarship at end of first } \\
\text { year (on being appointed Professor of } \\
\text { Physies at Central College, Banga- } \\
\text { lore, Mysore, India. }\end{array}$ \\
\hline $\begin{array}{l}\text { 271. Robinson, Robert, B.Se. Uiver- } \\
\text { Nominated by Victoria Univer } \\
\text { sity of Manchester }\end{array}$ & $1907-9$ & $\begin{array}{l}\text { Victoria University of Man- } \\
\text { chester and lederal P'oly- } \\
\text { technic, Zürich }\end{array}$ & $\begin{array}{l}\text { Organie Chomistry.-On the constitu- } \\
\text { tion of lerberin and liamatoxylin. } \\
\text { On the eonstitution of brazilin and } \\
\text { hrematoxylin and the synthesis of } \\
\text { opium alkaloids }\end{array}$ & D.Se. Victoria & $\begin{array}{l}\text { Junior Demonstrator in Organie } \\
\text { Chemistry, Vietoria University of } \\
\text { Manehester. }\end{array}$ \\
\hline $\begin{array}{l}\text { 272. Robison, Robert, A.I.C., B.Se., } \\
\text { London } \\
\text { Nominated by University College, } \\
\text { Nottingham }\end{array}$ & $1907-9$ & University of Leipzig. . . & $\begin{array}{l}\text { Organie Chemistry.-An investigation } \\
\text { of isomerism amongst esters and salts } \\
\text { of dimethylviolurie acid and allied } \\
\text { substanees, with speefal reforence } \\
\text { to the rclationship between colour } \\
\text { and constitution }\end{array}$ & $\begin{array}{l}\text { Ph.D. Leiprig } \\
\text { F.1.C. }(1908)\end{array}$ & $\begin{array}{l}\text { Assistant Leeturer in Chemistry, Uni- } \\
\text { versity College, Galway. }\end{array}$ \\
\hline $\begin{array}{l}\text { 273. Everatt, Reginald William, B.Se. } \\
\text { Nominated by University College } \\
\text { of North Wales, Bangor }\end{array}$ & $1907-8$ & St. John's College, Cambridge . & $\begin{array}{l}\text { Chemistry.-Interaction of diazonium } \\
\text { salts with phenols. Stereoisomerism } \\
\text { of nitrogen }\end{array}$ & M.Se. Wales & $\begin{array}{l}\text { Resigned Seholarship in June 1908, } \\
\text { on being appointed Assistant Master, } \\
\text { County Sehool, Pwllheli. }\end{array}$ \\
\hline $\begin{array}{l}\text { 274. Austin, Yerey Corlett, M.A. Cam- } \\
\text { bridge } \\
\text { Nominated by Queen's College, } \\
\text { Galway (now University Col- } \\
\text { lege, Galway). }\end{array}$ & $1907-9$ & $\begin{array}{l}\text { University College, London, } \\
\text { and University of Paris }\end{array}$ & $\begin{array}{l}\text { Organie Chemistry. - Synthesis of aeri- } \\
\text { dine derivatives. The condensation } \\
\text { of phenanthrenequinone with di- } \\
\text { methylaniline in tho presenee of } \\
\text { aluminium ehloride }\end{array}$ & - & $\begin{array}{l}\text { Leeturer in Chomistry, University } \\
\text { College, Reading. }\end{array}$ \\
\hline $\begin{array}{l}\text { 275. Simpson, James Crawford . } \\
\text { Nominated by MeGill University, } \\
\text { Montreal }\end{array}$ & $1907-9$ & $\begin{array}{l}\text { University of Cambridge and } \\
\text { Biologieal Laboratory, Ply- } \\
\text { mouth }\end{array}$ & $\begin{array}{l}\text { Embryology.-A study of the develop- } \\
\text { ment of Cueumaria }\end{array}$ & - & $\begin{array}{l}\text { 1909, Aeting Professor of Zoology; } \\
\text { I!10, Associate Professor of } \\
\text { Histology and Embryology, MeGill } \\
\text { University, Ilontrenl. }\end{array}$ \\
\hline $\begin{array}{l}\text { 276. Laidlaw, Campbell, B.A., M.D., } \\
\text { C.M. } \\
\text { Nominated by Qucen's Univer- } \\
\text { sity, Kingston, Ontario }\end{array}$ & $1907-9$ & $\begin{array}{l}\text { St. Mary's Hospital, London, } \\
\text { and the University of Tübin- } \\
\text { gen, Germany }\end{array}$ & $\begin{array}{l}\text { Theoretical Pathology.-A study of } \\
\text { opsonie methods }\end{array}$ & $\begin{array}{l}\text { Member of College } \\
\text { of Physicians } \\
\text { and Surgeons, } \\
\text { Ontario }\end{array}$ & $\begin{array}{l}\text { Appointed July, 1909, Direetor of the } \\
\text { Inoculation Department and Path- } \\
\text { ologist, St. Luke's General Hospital, } \\
\text { Ottawa, Canada. }\end{array}$ \\
\hline
\end{tabular}


277. Taylor, Thomas Griffith, B.Sc., B.E.

Nominated

by University of

Sydney

278. Stephens, Edith Layard, B.A. . Nominated by South African College, Cape Town

279. Trobridge, Fredcrick George,

$$
\text { B.Sc. }
$$

Nominated by Armstrong College,

Newcastle-upon-Tyne

280. Glaucrt, Edward Colver,

Nominated by University of Sheffield

281. Wallace, Robert Charles, M.A., B.Sc.

Nominated by University of Edin. burgh

252. McMillan, Andrew, M.A., B.Sc. Nominated by University of Glas gow
1907-1910 University of Cambridge . . Palæontology.-Morphology and affifinities of the lower Cambrian orranisations archeoeyathenae. The eoonomio aspect of Australian physiocraphy. The ovol

$1907-1910$

University of Cambridge

Botany.-A morphological, systematic, and inatomical study of the Pen'ca. eeae and (Geissolomacene. Apogamy in Pteris Droogmantiana. A jogamy in Mercurialis nnnua. Development of the seed-coat of Carica papaya. Examination of the embryo-saes of various Angiosperms. The anatomy of Cinetum Africanum

(Bursar)

1907-8

(Seholar)

1908-1910

(Bursar)

$1907-8$

Scholar)

1908-1910

1908-1911

$1908-1910$
Univcrsity of Sheffield and Royal Teehnieal High School, Charlottenburg

University of Göttingen and University College, Dundee

Organie Chemistry.-The constitution of itaconamide

Engineering.-Comparison of static and dynamie testing. Structurc of east iron water pipes. Ignition systems for internal combustion engines. Effect of nitrogen on iron and steel. Sulphurous acid as a metallographic etching medium. The magnetic properties of niekel stccls. The production of artifieial meteoric iron

Physical Chemistry.-The two-eomponent systems of various metasilieates. The dimorphism of the ammonium haloids. A crystallographical study of the thallic double graphic

University of Jena
Chemistry.-Constitution of gnoscopine, nornaceine, and methylhydrasteîne. 'Transformations and reac. tions of nareotine and hydrastine effected by various reagents
Geologist to the British Antarctic lixpedition, 1910

Ph.D. Bonn.

Demonstrator in Chemistry, Armstrong College, Newcastle-upon-Tyne.

A.I.A.E.

Private research work at Charlottenburg

Ph.D. Göttingen

Scholarship has been exceptionally renewed for a third yent.

Engaged in private research at University of Glasgow. 
LIST OF SCIENCE RESEARCH SCHOLARS APPOINTED BETWEEN THE YEARS 1891 AND 1910-continued.

\begin{tabular}{|c|c|c|c|c|c|}
\hline Name of Scholar & $\begin{array}{l}\text { Years of tenure of } \\
\text { Scholarship }\end{array}$ & $\begin{array}{l}\text { Places of stady during Scholarship } \\
\text {. }\end{array}$ & $\begin{array}{l}\text { Branch of Scicucc } \\
\text { and Principal subjects of Rescarch } \\
\text { during tenure of Scholarship }\end{array}$ & $\begin{array}{l}\text { Degrecs and other dis- } \\
\text { tinctions obtained } \\
\text { since appoiutment to } \\
\text { Scholarship }\end{array}$ & $\begin{array}{l}\text { Particulars of Scholar's subscquent career } \\
\text { as far as ascertained }\end{array}$ \\
\hline $\begin{array}{l}\text { 283. Stoward, Frcderick, M.Se. } \\
\text { Nominaled by University of Bir- } \\
\text { mingham }\end{array}$ & $1908-1910$ & $\begin{array}{l}\text { University of Birmingham and } \\
\text { Pastcur Institute, Paris }\end{array}$ & $\begin{array}{l}\text { Biological Chemistry.-The physio. } \\
\text { logy of the germination of barley: } \\
\text { 'The cytology of the cnzymc sccroting } \\
\text { cells of barley. The influenee of } \\
\text { certain acids on the aetivity of } \\
\text { suerasc }\end{array}$ & - & $\begin{array}{l}\text { Appointed Deccmber, } 1910 \text {, Botanist } \\
\text { and Plant Pathologist to the Depart. } \\
\text { ment of Agriculture, Perth, Wostorn } \\
\text { Australia. }\end{array}$ \\
\hline $\begin{array}{l}\text { 28. Irving, Annic Atkinson, B.Se. } \\
\text { Nominated by Univorsity of Bris- } \\
\text { tol }\end{array}$ & $1908-1911$ & University of Cambridge . & $\begin{array}{l}\text { Botanical Physiology.-Rclation be- } \\
\text { tween the grcening and assimilatory } \\
\text { power of young secdlings. Stimu- } \\
\text { latory and toxio effeets of anx- } \\
\text { stheties on respiration }\end{array}$ & - & $\begin{array}{l}\text { Scholurship has been cxceptionally re- } \\
\text { newad for a third year. }\end{array}$ \\
\hline $\begin{array}{l}\text { 285. Cross, Villiam Ernest, B.Sc. } \\
\text { Nominated by University of } \\
\text { Leeds }\end{array}$ & $1908-1910$ & University of Göttingon . & $\begin{array}{l}\text { Fcrmentation and sugar-chemistry.- } \\
\text { 'The occurrenec of acetyl and formyl } \\
\text { groups in lignin. Fermentation ex- } \\
\text { periments with the pentoses }\end{array}$ & Ph.D. Göttingen & $\begin{array}{l}\text { Appointed. July } 1910 \text {, Rescareh } \\
\text { Chemist in the Sugar laboratory of } \\
\text { the Louisiana University, New Or- } \\
\text { leans. }\end{array}$ \\
\hline $\begin{array}{l}\text { 286. Hughes, Arthur Llewelyn. B.Se. } \\
\text { Nominated by University of } \\
\text { Liverpool }\end{array}$ & $1908-1910$ & University of Cambridge . & $\begin{array}{l}\text { Physies. - Ionisation in gases by ultra- } \\
\text { violet hight. 'The ultra-violet light } \\
\text { from the mereury arc }\end{array}$ & $\begin{array}{l}\text { B.A. Cambridge } \\
(1910)\end{array}$ & $\begin{array}{l}\text { On the expiration of his Seholarship in } \\
\text { 1910. awarded a Resoarch Scholar- } \\
\text { ship by Emmanuel ('ollege. Cam- } \\
\text { bridge. }\end{array}$ \\
\hline $\begin{array}{l}\text { 287. Hilditeh, Thomas Perey, B.Sc., } \\
\text { A.I.C. } \\
\text { Nominated by Universityof London }\end{array}$ & $1908-1910$ & $\begin{array}{l}\text { University College, London, } \\
\text { and Universities of Jena and } \\
\text { Geneva }\end{array}$ & $\begin{array}{l}\text { Organie and l'hysieal Chemistry.- } \\
\text { 'Tho relation between chemical con- } \\
\text { stitution and optieal activity }\end{array}$ & - & $\begin{array}{l}\text { Scholarship has been exceptionally re- } \\
\text { neucd for a third year. }\end{array}$ \\
\hline $\begin{array}{l}\text { 288. Royds, Thomas, M.Se. } \\
\text { Nominated by Victoria Univer- } \\
\text { sity of Manehester }\end{array}$ & $1908-1911$ & $\begin{array}{l}\text { Vietoria University of Man- } \\
\text { chester and Universities of } \\
\text { Tübingen and Borlin }\end{array}$ & $\begin{array}{l}\text { Radio-activity and Speetroseopy-- } \\
\text { The speetrum of the radium emana- } \\
\text { tion. 'The grating spectrum of the } \\
\text { radium emanation. A comparison } \\
\text { of the radium speetra obtained by } \\
\text { different observers. 'The nature of } \\
\text { the a-particlc. 'The action of the } \\
\text { radium emanation on water. Fur- } \\
\text { ther experiments on the constitu- } \\
\text { tion of the eleetrie spark. The } \\
\text { Doppler effect in positive rays in } \\
\text { lydrogen. Zeeman cffect in eer- } \\
\text { tain serics consisting of single hines. } \\
\text { The roflective power of lamp and } \\
\text { platinum black }\end{array}$ & - & $\begin{array}{l}\text { Resigned Selolarship in Decembər, } \\
\text { 1910, on being appointed Assistant } \\
\text { Director of the Kodaikanal Solar } \\
\text { Physies Observatory, India. }\end{array}$ \\
\hline
\end{tabular}


289. Luff, Bernard Dunstan Wilkinson, A.1.C.

Nominated by University College, Nottingham

290. Sontherns, Leonard, B.Se.

Nominated by University of Shef-

201. Thomas, John, B.Se. Nominated by University College of Wales, Aberystwyth

292. Leonard, Alfred Godfrey Gordon, A.R.C.Se.I.

Nominated by Royal College of Seienee for Ireland

293. Beatty, Rishard T., M.A., B.E. Nominated by Queen's College, Belfast (now Queen's Luivor sity of Belfast)

294. Wright, Charles Seymour, B.Se. Nominated by University o 'T'oronto

295 Creighton, Henry Jermain Maude, II.A.

Nominated by Dalhousie University, Halifax, Nova Seotia
Unirersity College, Nottingham, and Vietoria University of Nanehester

1908-1911

University of Cambridge and National Physieal Laboratory

University of Bonn . . .

1908-1910

$1908-1910$

$1908-1910$

University of Cambridge .

$1908-1910$

Universities of Birmingham and Heiclolleris and fiedernt Polytechnic, Züirieh

Universities of Cambridge and Leeds
University of Cambridge . .

Chemistry.-Organic derivatives of silicon. Preparation of asymmetrie phorophsous compounds. M-hemipinic and asaronic acids. Experiments on the synthesis of the terpenes

Experimental Physies. - Investigation as to dependence of gravity on electrifiention. Determination of the ratio of mass to woight for a radio-aetive substanee

Chemistry.-The isolation of the aromatie sulphurie aeids. Resolution of tetrahydrodimethylquinoline

Organie Chemistry.-The constitution and absorption speetra of tartrazin and related compounds

Physies.-The behaviour of eleetrons emitted by metals under the in fluenee of eathode rays and Röntgen rays

Physies.-Natural ionisation in metal lic receivers. The number of $a$-partieles emitted by ordinary metals. The erystalline structure of iee in regard to its age and previous history (work undertaken in preparation for the British Antaretie Expedition, 1910)

Chemistry.-Solid solution. The eontamination of precipitated lorium culphate by iluminium salts. In ulphate by alhin luence of colloils on the solubility of gases in mater. like solubility of activation by means of eatalysts
1910, appointed Chemist to the Nort $t_{1}$ British Rubber Company, Edin. burgh.

B.A. Cambridge

Schnlurship has been excentionally re. newed for a third year.

B.A. Cambridgo

Scholarship has been exceptionally renewed for a third year.

B.Se. London

Pl..D. Bom

B.A. Cambridge

Scholarship recently expired.

10. appointed Assistant to Professo of Chemistry. University College, lialway.

Physieist to the British Antaretie Ex peclition, 1910.

M.Se. Birminglım ('ontinuing resenreh work at Zürich. (1909) 
LIST OF SCIENCE RESEARCH SCHOLARS APPOINTED BETWEEN THE YEARS 1891 AND 1910-continued.

Name of Scholar

296. Finlayson, Alexander Moncrieff, II.sio.

mmated by Üniversity of Yrev Zealand

297. Irving, Aubrey Gordon, B.A. Nominated by South African College, Cape Town

298. Jameson, Harold, B.Se. Nominated by Armstrong Collcge, Neweastlc-upon-Tyne

99. Watson, William, M.A., B.Se. Nominatediby University of Edin-

300. Russell, Alexander Smith, M.A., B.So Nominated by University of Glas. gow

301. Blackadder, Thomas. B.Sc. Nominated by University of St. Andrews

302. Todd, George William, M.Sc Nominated by University of Birmingham

303. Loslic, Nay Sybil, B.Se. Nominated by University of
Leeds

\begin{tabular}{|c|c|c|c|c|}
\hline $\begin{array}{l}\text { Ycars of tenure of } \\
\text { Scholarship }\end{array}$ & Placcs of study during Scholarship & $\begin{array}{l}\text { Branch of Science } \\
\text { and Principal subjects of Research } \\
\text { during tenure of Scholarship }\end{array}$ & $\begin{array}{l}\text { Degrces and other dis- } \\
\text { tinctions obtaincd } \\
\text { since appointment to } \\
\text { Scholarslip }\end{array}$ & $\begin{array}{l}\text { Particulars of Scholar's subsequent career } \\
\text { as far as ascertained }\end{array}$ \\
\hline $1908-1910$ & $\begin{array}{l}\text { Imperial College of Scicince and } \\
\text { 'Technology and at Rio 'Tinto, } \\
\text { Spain, for } 3 \text { months }\end{array}$ & $\begin{array}{l}\text { Economie Geology. - New Zealand } \\
\text { neplrite' and its matrix. Ore } \\
\text { sh ots on the Hauraki Goldfields. } \\
\text { New Zealand. 'The ore deposits of } \\
\text { the British Isles. The copper de- } \\
\text { posits of Hudva, Spain }\end{array}$ & $\begin{array}{l}\text { D.Se. London, } \\
\text { F.G.S. } \\
\text { Assoc. I.M.M. }\end{array}$ & $\begin{array}{l}\text { 'Daniel Pigeon' prizeman, Geological } \\
\text { Society of London. September, } \\
1910 \text {, appointed potroleum geologist } \\
\text { on the Burma oil-fields. }\end{array}$ \\
\hline $1908-1910$ & University of Cambridge . & $\begin{array}{l}\text { Engineoring.-Resistance of coment } \\
\text { mortar to repeated loads. Expori- } \\
\text { ments to try and discover whether } \\
\text { cement mortar yiolds by shear or } \\
\text { streteh }\end{array}$ & B.A. Cambridge & Scholarship reccntly expired. \\
\hline $\begin{array}{l}\text { (Bursar) } \\
\text { 1908-9 } \\
\text { (Not awarded } \\
\text { Scholarship in } \\
\text { 1909) }\end{array}$ & Armstrong College & $\begin{array}{l}\text { Physics.-On the relation between the } \\
\text { eomposition of certain alloys and the } \\
\text { potential acquired by them under } \\
\text { the influence of Röntgen rays }\end{array}$ & - & - \\
\hline $\begin{array}{l}\text { Appointed } \\
1909\end{array}$ & University of Loipzig. & $\begin{array}{l}\text { Physios.- The physical properties of } \\
\text { water al high temperatures and } \\
\text { pressures }\end{array}$ & - & $\begin{array}{l}\text { Scholarship reneved for sccond ycar, but } \\
\text { resigned in July, } 1910 \text {. }\end{array}$ \\
\hline $\begin{array}{l}\text { Appointed } \\
1909\end{array}$ & $\begin{array}{c}\text { Universities of Glasgow and } \\
\text { Berlin }\end{array}$ & $\begin{array}{l}\text { Radio-aetivity.-The } \gamma \text {-rays of the } \\
\text { radio-eloments. The chemistry of } \\
\text { the uranium-radium series of radio- } \\
\text { active elements }\end{array}$ & - & $\begin{array}{l}\text { Scholarship has been renewed for second } \\
\text { year. }\end{array}$ \\
\hline $\begin{array}{l}\text { Appointed } \\
1909\end{array}$ & $\begin{array}{l}\text { University of Heidelberg and } \\
\text { Federal Polytcehnic, Zürich }\end{array}$ & $\begin{array}{l}\text { Physieal Chemistry.-The catalytic } \\
\text { docomposition of formic acid }\end{array}$ & - & $\begin{array}{l}\text { Scholarship has been rencued for second } \\
\text { year. }\end{array}$ \\
\hline $\begin{array}{l}\text { Appointed } \\
1909\end{array}$ & University of Cambridge . & $\begin{array}{l}\text { Physics.-Phenomena connected with } \\
\text { the passage of clectricity through } \\
\text { gases. Positive ions at low pres. } \\
\text { sures }\end{array}$ & - & $\begin{array}{l}\text { Scholarship has bcen renewed for second } \\
\text { year. }\end{array}$ \\
\hline $\begin{array}{l}\text { Appointed } \\
1909\end{array}$ & University of Paris . & $\begin{array}{l}\text { Chemistry. }-1 \text { detailed study of the } \\
\text { mineral thorite and of other minerals } \\
\text { of thorium }\end{array}$ & - & $\begin{array}{l}\text { Scholarship has been renewed for second } \\
\text { year. }\end{array}$ \\
\hline
\end{tabular}


304. Robinson, Frederick William, B.Sc.

Nominated by University of Liverpool

305. Watson, Herbert Edmeston, B.Sc., A.I.C.

Nominated by Unfersity of London

306. Haworth, Walter Norman, M.So Nominated by Victoria University of Manchester

307. Grecnwood, Harold Cccil, M.Sc. Nominated by Victoria University of Manchester

308. Vernon, Robert Douglas, B.Sc. . Nominated by University College, Nottingham

309. Vanstonc, Ernest, B.Sc. Nominated by University College of South Wales and Monmouthshire, Cardiff

310. Compton, Arthur, M.A., M.B. Nominated by Qucen's College, - Galway

311. Boyle, Robert William, M.Sc. Nominated by MeGill University, Montreal

312. Bowen, Norman T.evi, M.A., B.So Nominated by Quecn's University. Kingston, Ontario

313. Swain, Herbert John, B.Eng. Nominated by University of Sydncy
Appointed 1909

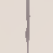

Appointed 1909

Appointed 1909

Appointed 1909

Appointed 1909

Appointed 1909

Appointed 1909

Appointed 1909

Appointed 1909

Appointed 1909
Physieal Chemistry.-Inrestigation of the separated benzene flame

Universities of Berlin, Genera, Physical Chemistry.-A complete study and Cambridge

University of Göttingen and Victoria University of Manchester

Technieal High School, Karlsruhe and National Physical Laboratory University of Cambridge .

University College, London . .

Pasteur Institute, Paris . .

Victoria University of Manehester

Massachusetts Institutc of Technology, and Gcophysical Laboratory Carnegie Institution, Washington

University of Cambridge . . Engincering.-Heat flow in the gas engine

Organic Chemistry.-Rcsearch on the synthesis of fenchone, camphenilone, and other members of the eamphor and terpene series

Physical Chemistry.-The preparation of ammonia from its clements under the catalytic action of uranium and uranium carbide

Geology.-The geology and paleontology of the Warwickshire eoalfield and of its surrounding red rocks, supposed to bc of Permian age

Physical Chemistry. - The speeific volumes of the mercury alloys with the allali metals

Biologieal Chemistry.-Studies in enzyme aetion : cellasc

Radio-aetivity.-Experiments on the physieal-chemienl propertics of the cmanations On diabase and granophyre of the Gowganda Lakc Distriet, Ontario
Scholarship has been renewed for second year.

Scholarship has been renewed for second year.

Petrology and Petrographic Gcology.-

Scholarship has been renexced for second year.

Scholarship has been renewed for second year. cholarship hus been renewed for second year.

Scholarship has been renewed for second year.

Scholarship has been renewed for second year.

Scholarship has been renewed for second year.

Scholarship has been renewed for second year.

Scholarship has been renewed for second year.

(


LIST OF SCIENOE RESEARCH SCHOLARS APPOINTED BETWEEN THE MEARS 1891 AND 1910-continued.

\begin{tabular}{|c|c|c|c|c|c|}
\hline Name of Scholar & $\begin{array}{l}\text { Years of tenure } \\
\text { of Schularship }\end{array}$ & Places of study during Scholarship & $\begin{array}{l}\text { Branch of Science } \\
\text { and Principal subjects of Research } \\
\text { during tenure of Scholarship }\end{array}$ & $\begin{array}{l}\text { Degrees and other dis- } \\
\text { tinctious obtained } \\
\text { sinee aypuintwent to } \\
\text { Schiolarship }\end{array}$ & $\begin{array}{l}\text { Particulars of Seholar's subsequent carcer } \\
\text { as far as ascertainel }\end{array}$ \\
\hline $\begin{array}{l}\text { 314. Gray, Josepd Alexander, B.Se. } \\
\text { Nominated by University of IIel- } \\
\text { bourne }\end{array}$ & $\begin{array}{l}\text { Appointed } \\
1909\end{array}$ & $\begin{array}{l}\text { Victoria University of Man- } \\
\text { chester }\end{array}$ & $\begin{array}{l}\text { Radio-activity.-Further experiments } \\
\text { on the } \beta \text { and } \gamma \text { rays of radium and } \\
\text { other radio-aetive substances }\end{array}$ & 一 & $\begin{array}{l}\text { Scholarship hus been rènewed for sccond } \\
\text { year. }\end{array}$ \\
\hline $\begin{array}{l}\text { 315. Glasson, Joseph Leslic, B.Se. } \\
\text { Nominated by University of Ade- } \\
\text { laide }\end{array}$ & $\begin{array}{l}\text { Appointed } \\
1909\end{array}$ & University of Cambridge . & $\begin{array}{l}\text { Physies.-The specific ionisation of } \\
\text { cathode rays of different velocities }\end{array}$ & - & $\begin{array}{l}\text { Scholarship has been renewed for second } \\
\text { year. }\end{array}$ \\
\hline $\begin{array}{l}\text { 316. Bowden, Edward, B.Sc. } \\
\text { Nominated by Armstrong College, } \\
\text { Noweastle-upon-'Iyne }\end{array}$ & $\begin{array}{l}\text { (Bursar) } \\
1909-1910 \\
\text { Appointed } \\
\text { (Scholar) } \\
1910\end{array}$ & $\begin{array}{l}\text { Armstrong College and Technical } \\
\text { High School, Karlsrulıo }\end{array}$ & $\begin{array}{l}\text { Engineering.-Whe electrie break-down } \\
\text { of insulating materials under impul- } \\
\text { sive pressure rise }\end{array}$ & - & Scholarship recently awarded. \\
\hline $\begin{array}{l}\text { 317. Stanficld, George, B. Eng. } \\
\text { Nominated by University of Shef- } \\
\text { field }\end{array}$ & $\begin{array}{c}\text { (Bursar) } \\
1909-1910 \\
\text { (Not awarded } \\
\text { Scholiniship in } \\
\text { 1910) }\end{array}$ & University of Sheffield & $\begin{array}{l}\text { Electricity and Magnetism. - Losses and } \\
\text { heating effeets in alternating eurrent } \\
\text { transformers. Ballistic method of } \\
\text { magnetic testing }\end{array}$ & 一 & 一 \\
\hline $\begin{array}{l}\text { 318. MeDavid, James Wallace, B.Se. . } \\
\text { Nominated by University of Edin- } \\
\text { burgh }\end{array}$ & $\begin{array}{l}\text { Appointed } \\
1910\end{array}$ & $\begin{array}{l}\text { Victoria University of Man- } \\
\text { chester }\end{array}$ & $\begin{array}{l}\text { Organic Chemistry.- Synthosis of al- } \\
\text { kaloids or other natural substances }\end{array}$ & - & Scholarship recently awarded. \\
\hline $\begin{array}{l}\text { 319. Grove, Alfred John, M.Sc. } \\
\text { Nominated by University of Bir- } \\
\text { mingham }\end{array}$ & $\begin{array}{l}\text { Appointed } \\
1910\end{array}$ & University of Cambridge . & $\begin{array}{l}\text { Biology.-The biology of injurious in- } \\
\text { seet pests }\end{array}$ & - & Scholarship recently awardcd. \\
\hline $\begin{array}{l}\text { 320. Joyner, Reginald Arthur, B.Se. } \\
\text { (London) } \\
\text { Nominated by University of Bris- } \\
\text { tol }\end{array}$ & $\begin{array}{l}\text { Appointed } \\
1910\end{array}$ & Federal Polytcchnic, Zürich . & Rescarch under Prof. Bredig . & - & Scholarship recently awarded. \\
\hline $\begin{array}{l}\text { 321. Dudley, Harold Ward, B.Sc. } \\
\text { Nominated by University of } \\
\text { Lecds }\end{array}$ & $\begin{array}{l}\text { Appointed } \\
1910\end{array}$ & University of Berlin . & $\begin{array}{l}\text { Organic Chemistry.-The metliylation } \\
\text { of guanine }\end{array}$ & - & Scholarship recently awarded. \\
\hline $\begin{array}{l}\text { 322. Allmand, Arthur John, M.Sc. } \\
\text { Nominated by University of } \\
\text { Liverpool }\end{array}$ & $\begin{array}{l}\text { Appointed } \\
1910\end{array}$ & $\begin{array}{l}\text { Technical High Sehool, Karls- } \\
\text { ruhe }\end{array}$ & $\begin{array}{l}\text { Physieal Chemistry.-Optical measure- } \\
\text { ment of the temperatures of different } \\
\text { flames }\end{array}$ & - & Scholarship recently awarded. \\
\hline
\end{tabular}


323. Andrado, Edward Nevillo da Costa, B.Se.

Nominated by University of London

324. Wilson, William, M.Se. Nominated by Vietoria University of Manehester

325. Forster, Aquila, B.Se. . Nominated by Armstrong College Ncweastle-upon-'Iync

326. Challenger, Froderiek, B.Sc.

$$
\text { (Lonclon) }
$$

Nominated by University College Nottingham

327. Merry, Ernest Wyndham, B.Se. Nominated by University of Sheffield

328. Owen, Edwin Augustus, B.Se. . Nominated by University College of North Wales, Bangor

329. Graham, Joseph Ivon, B.Se. (London)

Nominated by Royal College of Seicnco ior Ireland

330. Crymble, Cceil R., B.A., B.Se (R.U.J.)

Nominated by Queen's University of Belfast

331. Thompson, Walter Palmer, B.A. Nominated by University of Toronto

332. Wallaee, Curtis Clayton, B.Se. Nominated by University of Dal housie, Halifax, Nova Seotia
Appointed 1910

Appointed

1910

Appointed 1910

Appointed 1910

Appointer 1910

Appointed 1910

Appointed 1910

Appointed 1910

Appointed 1910 1910
University of Hoidelberg .

University of Cambridge

University of Freiburg

University of Göttingen

University of Würzburg

University of Cambridge . .

University of Cambridge .

Stcreo-ehemistry - Examination and measurement of the moleeular rotation of sulphonic acid and soveral salts under different conditions of eoncentration, ete.

Queen's University of Belfast .

Biologieal Chemistry.-On absorption speetra, and on the bio-chemistry of ulva latissima

Botany.-The structure of wood .

Harvard Univorsity .

Organie Chomistry. - The nat ure of the isomen ism of the rehitisehen bases
oltained from homosalicylaldehyde

Physies.-On seeondary $x$-rays (1)

Harvard Unirorsity .

hysics.-Behaviour of metals under cxeessive stresses, espeeially in eases

Radio-netivity. - The absorption of

Chemistry.-The organie derivatives of sulphur

Organie Chemistry. - Derivatives of the thujone series

1

Chemistry, - Research in problems re lating to quinone, or other problem in organie or analytical chemistry 


\section{INDEX TO SCHOLARS}

(in foregoing list)

Name.

Abell, R. D.

Allon, J. B.

Allmand, A. J.

Andrade, E. N. da C.

Andrew, A. Ii.

Annett, $\mathrm{H}$. $\mathrm{C}$.

Archibald, E. H.

Armes, H. P.

Ashton, A. W.

Aston, Miss E.

Austin, P. C.. .

Baker, 'I'.

Baker, W. C.

Baldwin, J. M.

Baly, E. C. C.

Barkel', J. 'I'.

Barkla, C. G.

Barmes, J.

Iarraclough, S. H.

Barrow, F

Barton, E. H.

Bassett, $\mathrm{H}$.

Beattie, J. C.

Berttie, R.

Beatty, R. 'T.

Black, T. P.

Blackadder, T.

Blyth, V. J.

Bolan, H. W.

Bottomley, J. F.

Bowden, E.

Bowen, N. L. .

Boyd, A.

Boyle, R. IV.

Bradshaw, L. .

Bray, IW. C.

Brown, E.

Bryan, G. B.

Bryant, Miss E. M.

Buller, A. H. R.

Burnie, IV. B.

Burt, F. P.

Burton, E. F.

Butler, E. J. .

Cain, J. C.

Caldwell, K. S.

Caldwell, IV.

Calvert, H. 'T.

Cameron, A. T.

Campbell, W.

Carmichael, N. R.

Carnwath, T.

Carse, G. A.

Caspari, W. A.

Challenger, F.

Chick, Miss H.

Clark, R. H.

Clarke, E.

Clarke, Miss R.

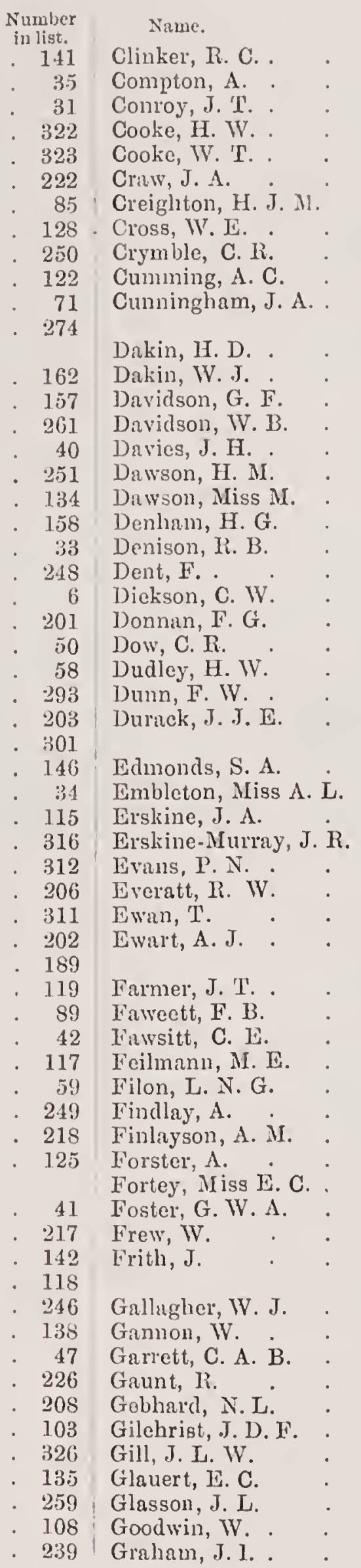

in list.

53

310

23

205

178

163

295

285

330

221

154

184

269

333

.2

256

84

109

262

165

54

173

45

176

321

14

159

195

153

95

51

15

273

55

55

70

145

7.4

120

116

296

325

83

215

3

57

238

29

237

199

198

64

111

280

315

188

329
Name.

Granger, J. D.

Gray, J.A.

Gray. J. H.

Greenwood, H. C. . . 307

Grindley, J. H. 105

Grove, A. J. . . . 319

Gwyer, A. G. C. . . 231

Hallaway, R. R. . . 106

Hanua, W. . . . 75

Harker, G. . . . 174

Harrison, E. P. . . 186

Haworth, H.F. . . 213

Hawortl, W. N. . . 306

Hawtlorme, J. . . 171

Heatheote H. I. . . 131

Hebb, T. C. . . . 190

Hedley, E. P. . . 257

Heinke, J. L. . . 87

Hender'son, J. ․ $\quad$. $\quad 67$

Henderson, J. B. . . 18

Henderson, IV. C. . $\quad 80$

Henry, J. . . . 92

Herbertson, A. J. . . 17

Hilditch, T. P. • . 287

Hodsman, H. J. . 268

Holt, R. . . . . 10

Horton, F. . . . 160

Hosking, R. . . . 191

Houstoun, R. A. . . 209

Hoyles, Miss A. J. . . 11

Hughes, A. L. $\quad$. 286

Humfrey, J. C. W. . . 149

Hunter, M. A. • . 192

linms, A. D. . . . 230

Ingle, $H$. . . . 9

lnglis, J. K. H. . 179

Innes, P. D. . . . 227

lrvine, J. C. . . . 130

Irving, Miss A. A. . . 284

Irving, A. G. . . . 297

Jack, R. . . . . 247

Jackson, D. H. . . 32

Jacot, E. . . . 336

Jameson, H. . . . 298

Jenkins, J. T. . . . 140

Johnson, F. M. G. . 240

Johmston, J. . . . 229

Jones, E. 'T. - . . 27

Joyner, R. A. . . 320

Kry, F. W. . . . 253

Kay, S. A. . . . 99

Kenrick, F. B. . . 62

King, R. O. . . 76

Kleeman, R. D. - . 243

Knight, C. W. . • . 219

Knox, J. . • • . 210

Kyle, H. if. : . 98 


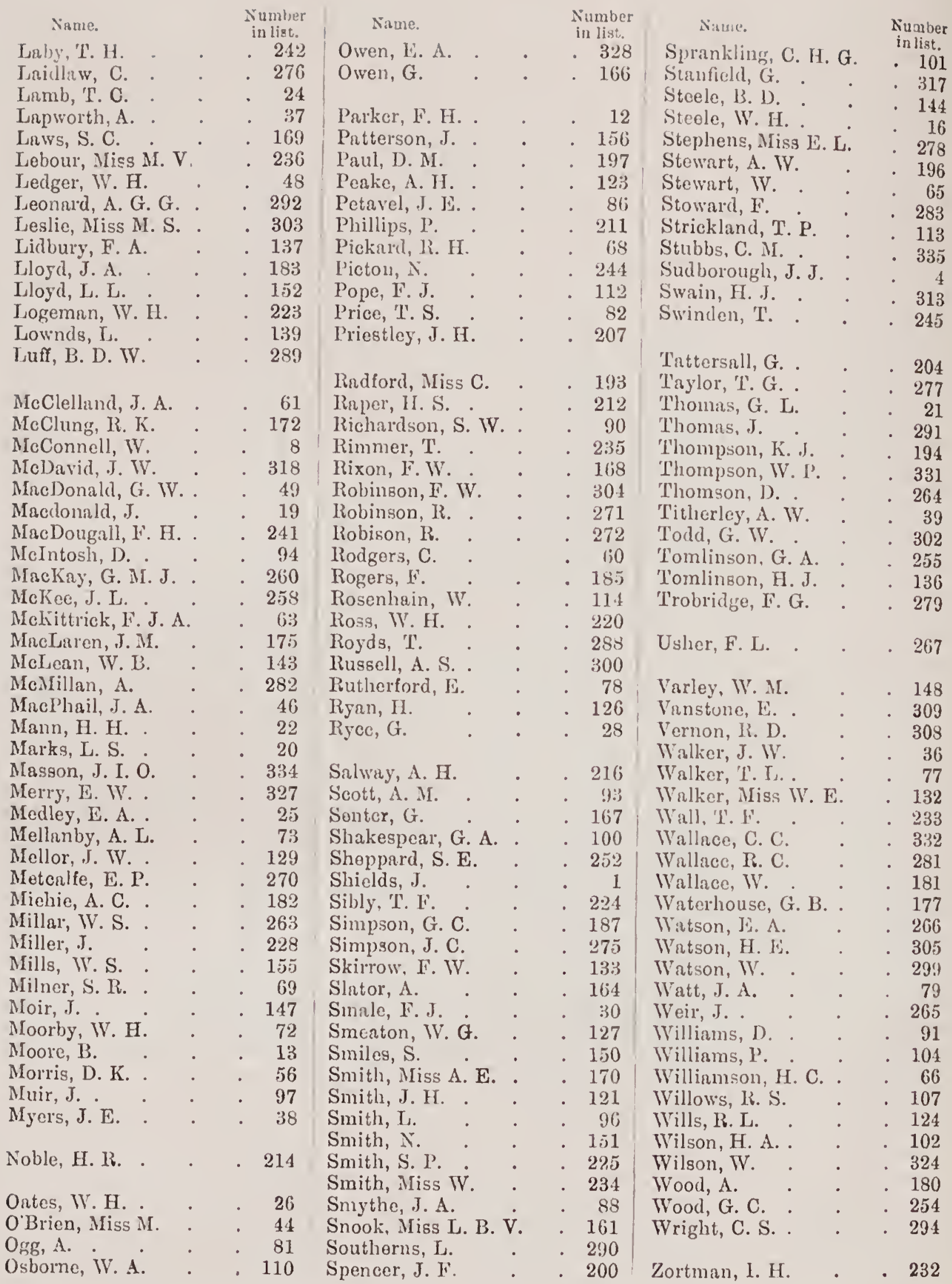




\title{
INDEX TO NOMINATING INSTITUTIONS
}

\author{
(in foregoing list).
}

Name of Institution.

Aberdeen, University of

Aberystwyth, University College of Wales,

Adelaide, University of

Bangor, University College of North Wales,

Belfast, Queen's Univer'sity of (formerly Queen's College)

Birmingliam, Univer'sity of (formerly Mason College of Seience)

Bristol, University of . (formerly University College)

Cape Town, South Afriean College, .

Cardifi, University College of South Wales and Monmouthshire,

Cork, University College, (formerly Queen's College)

Dublin, Royal College of Seience for Ireland,

Edinburgh, University of

Galway, University College, (formerly Queen's College)

Glasgow, University of

Leeds, University of . (formerly Yorlishire College)

Liverpool, University of

London, University of (formerly University College)

Manchester, Vietoria University of (formerly Ovens College)

Melbourne, University of .

Montreal, MeGill University,

Newcastle-upon-Tyne, Armstrong College, . (formerly Durlum College of Seienee)

New Zealand, University of

Nottinghun, University College,

Nova Scotia, Dalhousie University, Halifax,

Ontario, Queen's University, Kingston,

St. Andrews, University of (ineluding University College, Dundec)

Sheffield, University of

Sydney, University of (formerly Firth College)

Toronto, University of
Siumbers in List.

Nos. 19, 52, 81, 116, 147, 182, 210.

Nos. 44, 30, 140, 194, 244, 291.

Nos. 3, 31, 178, 243, 315 .

Nos. 27, 91, 141, 170, 217, 273. 328.

Nos. 13, 45, 75, 110, 142, 171, 226, 258, 293, 330.

Nos. $4,20,37,68,82.100,117,131,160,164$, $183,198,211,230,248,266,283,302,319$.

Nos. 7, 21, 53, 69, 83, 101, 132, 161, 207, 224 . $231,24 !, 267,284,320$.

Nos. 223, 278, 297, 336 .

Nos. 12, 109, 153, 256, 309.

Nos. 28, 125, 238.

Nos. $14,124,154,195,257,292,329$.

Nos. $1,17,34,50,64,96,145,179,208,227,246$, $263,281,299,318$.

Nos. 29, 61, 92, 126, 155, 188, 239, 274, 310 .

Nos. $2,18,35,51,65,80,97,115,146,163,180$, $196,209,228,247,264,282,300$.

Nos. 9, 22, 38, 54, 84, 102, 118, 133, 148, 165, $184,199,212,232,250,268,285,303,321$.

Nos. $10,23,39,55,70,85,103,119,134,149$, $166,185,200,213,233,251,269,286,304,322$.

Nos. $40,56,71,86,104,120,135,136,150,167$, $186,201,214,234,252,270,287,305,323$.

Nos. 5, 24, 41, 57, 72, 87, 105, 121, 137, 151, 168, $187,202,215,235,253,271,288,306,307,324$.

Nos. 16, 49, 114, 144, 191, 221, 261, 314, 334 .

Nos. $15,46,76,111,143,172,205,240,275,311$.

Nos. 8, 42, 58. 73, 88, 106, 122, 138, 162, 176, $203,225,236,254,279,298,316,325$.

Nos. 32, 78, !5, 129, 175, 192, 222, 262, 296, 335.

Nos. $(6,25,43,59,74,89,107,123,139,152,169$. $204,216,237,255,272,289,308,326$

Nos. $63,94,128,158,190,220,260,295332$.

Nos. $47,77,112,157,173,219,211,276,312$.

Nos. $3,36,66,67,98,99,130,181,197,229,265$, 301 .

Nos. 11, 26, 60, 108, 177, 193, 245, 280, 290, 317, 327.

Nos. $33,48,79,113,159,174,206,242,277,313$, 333 .

Nos. $30,62,93,127,156,189,218,259294,331$. 
APPENDIX E.

(See Report, page 1.3.)

\section{Lease of the Site of the Royat Coliege of Music.}

This INDenture, made the 30th day of Deeember 1891, between the Commissioners for the Exhibition of 1851 (hereinafter ealled "the Commissioners") of the one part, and the Royal College of Music (hereinafter called "the College") of the other part, Witnesseth, that in consideration of the Rents and Covenants by the College hereinafter reserved and contained, the Commissioners do liereby demise unto the College ALL that piece or pareel of land, situate on the south side of a new road known or intended to be known as "Prinee Consort Road," in the parish of St. Margaret, Westminster, in the County of Middlesex, and abutting north on the said new proposed road, south on a strip of land proposed to be leased to the Imperial Institute, east and west on land proposed to be demised to George Newman, eontaining on the front and rear thereof 200 feet, and on the east and west sides thereof 200 feet, all which said piece or pareel of land is part of the Estate of the Commissioners known as the Kensington Gore Estate, and is with the abuttals thereof more partieularly described and delineated in the plan drawn on these Presents and is therein eoloured blne and yellow: Together with the right to the free and uninterrupted aceess of light and air, at all times hereafter during the term hereby demised, over the piees of land shown by the colour red on the said plan or any part thereof, to all and any buildings which now are or shall hereafter be ereeted on the lands, hereby demised, or any part thereof: And also together with all easements and appurtenances to the said premises hereby demised, except nevertheless and reserving to the Commissioners, their suecessors and assigns, full and free right and liberty to obstruct and withioia the light and air (other than the light and air the rights to which are hereinbefore expressly granted) eoming to the said pieee or pareel of land and any building or buildings erected or to be erected thereon, over and from any other land or hereditaments of the Commissioners, their suceessors or assigns, and generally to use and deal with all other parts of the said Kensington Gore Estate in like manner in all respects, as if the said premises hereby demised had not been part of such estate, and as if the Commissioners had never any estate or interest therein, it being the meaning and intent of these Presents, that any such withloolding or obstruction of light and air and other sueh user and dealing as aforesaid shall not be deemed to be a derogation from the demise hereby made, and also cxeept and reserved, as aforesaid, aceess of light and air over the piees of land shewn by the colonr yellow on the said plan free from all buildings and ereetions thereon, and also exeept and reserving unto the Commissioners, their successors and assigns, full and free right and liberty to use all sewers and drains eoming through or under the said demised premises or from any other land or hereditaments of the Commissioners, their sueeessors or assigns: To hold the said premises unto the College and their sueeessors. from the 24th day of June 1890 for the term of 999 years, yielding and paying therefor the yearly rent of $£ 5$, without any deduetion (exeept for Landlords' Property Tax), on every 24 th day of June during the said term, the first payment whereof shall be made on the 24 th day of June 1891. And the College do for themselves and their suecessors hereby 
eovenant with the Commissioners, their sneeessors and assigns, that the College or their suecessors during the said term will duly pay the said rent hereby reserved on the day and in manner aforesaid, and will also pay all rates, taxes, assessments, impositions and outgoings whatsoever (whether annual or otherwise), now or hereafter ehargeable or payable on or in respeet of the said premises or on or by either Landlord or Tenant in respeet thereof: And will before the expiration of three years from the commencement of the term, at the cost of the College, ereet on the said picee or pareel of land hercby demised buildings, suitable for a College building for the purposes of the Charter of the College, of a good and substantial charaeter and with the best materials and workmanship, to the satisfaetion in all respects as to Plans, elevation, and otherwise of the Commissioners, their suecessors or assigns. And will during the said term, to the like satisfaetion, maintain such College building in complete working order and keep sueh building or buildings or any building or buildings, whieh may from time to time be substituted therefor, and all fixtures and fittings in and upon the same, in good and substantial repair and condition, and will at the expiration, or sooner determination of the said term, deliver up to the Commissioners, their sueeessors or assigns, the said pieee or pareel of land hereby demised with the building or buildings then ereeted thereon, and all fixtures and fittings in and upon the same, in like good and substantial repair and condition: And that the College or their suecessors shall not at any time make any alteration whatever in the elevation or the arehitectural deeorations of the said buildings and premises hereby demised or any future erections to be built on the said premises or any part thereof without the eonsent in writing of the Commissioners, their suceessors or assigns, and shall not nor will ereet or set up any additional creetions or buildings in or upon any part of the said premises without the previous written consent of the Commissioners, their suceessors or assigns: And shall not nor will at any time eut or injure any of the prineipal timbers or walls of the buildings, from time to time standing or being upon the said premises: And that the College and their suecessors during the said term will keep the building or buildings for the time being ereeted upon the piee or pareel of land insured against loss or damage by fire in the joint names of the College and their sueeessors, and the Commissioners, their successors and assigns, in the full value thereof, in the Allianee Fire Insuranee Offiee, or some other Offiee in London or Westminster, to be from time to time named by the Commissioners, their suceessors or assigns. And will from time to time, on demand, produee to the Commissioners, their sueeessors or assigns, or their Secretary or agent for the time being, the reeeipt or reeeipts for the eurrent year's Prenium or Premiums, payable in respeet of the Policy or Policies of every or any sueh Insurance, and in ease any sueh building as aforesaid shall suffer any loss or damage by fire, then and so often as the same sliall happen, the College or their suceessors will, by means of any moneys which shall be received by them under any such Insurance as aforesaid, and (if necessary) at their own further expense, well and properly to the satisfaetion in all respeets of the Commissioners, their sueeessors or assigns, rebuild, repair, or re-instate the premises whieh shall have suffered such loss or damage, and that during the said term the College will use the said premises and every part thereof for the purposes of the Royal Charter, by whieh the College are ineolporated, and of any Charter or Charters hereafter granted by way of Supplement thereto or in substitution therefor, and for no other purpose whatever: And will not assign, nuderlet, or part with the possession of the said premises or any part therecf to any Corporation or person whatever: And that 
the two pieees of land, shewn by the colour yellow on the said plan, being portions of the premises hereby demised, shall at all times hereafter be kept by the College and their sueeessors open and unbuilt upon, and that no ereetion or thing shall at any time be plaeed thereon, which may in any degree obstruet or interfere with the access of air or light to any buildings, whieh shall at any time be on the piees of land shewn by the colours brown and purple on the said plan, or either of them. And the Commissioners for themselves, their sueeessors and assigns, do hereby eovenant with the College and their sueeessors, that they will, within two years from the date hereof, form or eause to be formed the road, intended to be ealled the Prince Consort's Road, with all sewers, pavings, eurb and channels: And the College do hereby, for themselves and their suecessors, covenant with the Commissioners, their sueeessors and assigns, that they, the College or their sueeessors, will repay to the Commissioners one half the eost of making the road, sewers, pavings, eurb and ehamnels in respeet of their frontage of 200 feet thereto, that is to say, the whole cost to the centre of the road, and will also pay their proportion of the eost of maintenanee of the said road, until the same be taken to by the Parish: And the Commissioners do hereby further eovenant with the College, that they will at their own expense within three years from the date hereof lay out as gardens, courts and terraees the plot of land, situate on the northern side of the premises, hereby demised, which Plot is eoloured green on the said plan, and in whieh the Memorial of the Exhibition of 18.51 is intended to be placed, and will from time to time and at all times during the sail term keep such gardens, eourts and terraees planted, turfed, eleaned and generally kept in good, deeorative and substantial repair and eondition: And the College do hereby for themselves and their suecessors, eovenant with the Commissioners, their suceessors and assigns, that the College or their suecessors will from time to time and at all times during the said term pay to the Commissioners a fair proportion of the expense ineurred by them in keeping sueh gardens, courts, and terraees planted, turfed, eleaned, and keeping in good, decorative and substantial repair and eondition as aforesaid, sueh proportion to be settled by the Surveyor for the time being to the Commissioners, their sueeessors or assigns: Provided ALWAYs, that if at any time during the said term any payment in respeet of the said rent, hereby reserved, shall be in arrear for twenty-one days after the same shall have beeome due, or there shall be a breach, non-performanee, or non-observanee of any of the eovenants on the part of the College hereinbefore eontained, then and whenever the same shall happen, it shall be lawful for the Commissioners, their sueeessors or assigns, to enter upon the said premises or any part thereof in the name of the whole, and to determine the demise hereby made and the said term hereby granted, and sueh demise and term shall thereupon determine, but without prejudiee to any rights of action or other remedy which the Commissioners, their sueeessors or assigns, may for the time being have against the College in respeet of any sueh arrears of rent, or breaeh, non-performanee, or non-observanee of eovenant as aforesaid: And the Commissioners do hereby covenant with the College that, notwithstanding anything by the Commissioners done or knowingly suffered, the College paying the. said rent and performing and observing the eovenants by the College herembefore eontained, may quietly possess and enjoy the said rremises and every part thereof during the said term without interruption or disturbanee by the Commissioners or any Corporation or person lawfully elaiming through, under, or in trust for them. Iv witwess \&e. 
APPENDIX F.

(See Report, page 14.)

\section{Lease of the Site (and Butlding) of the Royal Coldege of ORgANISTS.}

This Indenture, made the 22nd day of Oetober,1903, between the Commissioners for the Exhibition of 1851 (hereinafter ealled "the Commissioners") of the one part, and the Royal College of Organists (hereinafter ealled "the College") of the other part: Whereas the Commissioners have agreed that the College shall be given the use of the premises hereinafter deseribed, so long as they require them for the purposes of their Charter and use them for sueh purposes, and subjeet to the terms of these presents: Now these Presexts witress, that in pursuance of sueh agreement and in consideration of the rent hereby reserved and the eovenants hereinafter eontained:

1. The Commissioners do hereby demise unto the College als that pieee of land situate on the west side of the Royal Albert Hall in the Parish of St. Margaret's, Westminster, in the County of Middlesex, together with the buildings thereon ereeted, formerly oceupied by the National Training Sehool of Musie, and late in the oeeupation of the Royal College of Musie, which said premises are more partienlarly delineated and deseribed in the map or plan thereof drawn on these presents and thereon eoloured pink, To Hold the said premises for the term of ninety-nine years from the 24th day of June 1903, if the College shall so long require them for the purposes of their Charter and use them for sueh purposes, yielding and paying therefor yearly the rent of 1l. without any deductions (exeept the Landlord's Property Tax) on every 24 th day of June during the said term, the first payment to be made on the 24 th day of June 1904.

2. The College do hereby eovenant with the Commissioners, that the College will, during the said term, pay the said rent hereby reserved on the day and in the manner aforesaid, and will also pay all rates, taxes, assessments, impositions and outgoings whatsoever (whether annual or otherwise), now or hereafter chargeable or payable on or in respeet of the said premises or on or by either landlord or tenant in respeet thereof.

3. The College will, at their own expense, keep the said premises and all fixtures and fittings therein in good and substantial repair and eondition to the satisfaetion of the Commissioners, their suceessors or assigns, and it shall be lawful for the Commissioners, their suceessors or assigns, or their surveyor or other offieer for the time being, from time to time at all reasonable hours (after giving the College not less than twenty-four hours' notiee in writing of their or his intention so to do) to enter into and upon the said premises and view the state thereof.

4. The College will at their own expense forthwith, after reeeiving a requisition in writing to that effect from the Commissioners, their suecessors or assigns, or their surveyor or other offieer for the time being, make good any defects or wants of reparation which may subsist in the said premises contrary to the preceding clause of these presents, and will, on the determination of the lease hereby granted, deliver up the said premises with the fixtures and fittings thereon to the Commissioners, their successors or assigns, in such good and substantial repair as aforesaid. 
5. The College shall use the said buildings or tenements as aforesaid for the purposes of the College as defined by their said Charter and for no other purposes whatsoever.

6. The College will not at any time make any alteration in the elevation or architectural decoration of the said buildings and premises hereby demised, or any future erections to be built on the said premises or any part thereof, without the consent in writing of the Commissioners, and shall not nor will erect or set up any additional erections or buildings in or upon any part of the said premises withont the previous written consent of the Commissioners, and shall not nor will at any time cut or injure any of the principal timber or walls of the buildings from time to time standing and being upon the said premises, and will not assign, underlet or in any way part with the possession of the said premises.

7. The College will, at their own expense, insure and keep insured the said building hereby demised against loss or damage by fire in the joint names of the College and their successors and of the Commissioners, their successor's and assigns, in the sum of 7,000l. at the least, in The Alliance Insurance Office or some other fire insurance office in London or Westminster to be from time to time named by the Commissioners, their successors and assigns, and will, within seven days after every premium payable in respect of such insurance shall become due, deliver if demanded to the Commissioners, their successors or assigns, the receipt for such preminm, and in case any building as aforesaid shall suffer any loss or damage by fire, then and as often as the same shall happen, the College will by means of moneys which shall be received by them under such insurance as aforesaid, and, if necessary at their own further expense, well and properly, to the satisfaction in all respects of the Commissioners, their successors and assigns, repair and reinstate the said premises which shall have suffered such loss and damage: Provided always that if at any time during the said term the College sliall cease to require the said premises for the purposes of their Charter or shall cease to use them for such purpose, or if any payment in respect of the said rent hereby reserved shall be in arrear for twenty-one days after the same shall have become due or there shall be any breach, non-performance or non-observance of any of the covenants on the part of the College hereinbefore contained, and in particular if the said premises shall be used for any purpose other than the purpose of the said Charter, then, whenever the same shall happen, it shall be lawful for the Commissioners, their successors or assigns, to enter upon the said premises or any part thereof in the name of the whole, and to determine the demise hereby made and the said term hereby granted, and such demise and term shall thereupon determine, but without prejudice to any right of action or other remedy which the Commissioners, their successors or assigns, may for the time being have against the College in respect of any such arrears of rent, or breach, non-performance or non-observance of covenant as aforesaid.

8. And the Commissioners do hereby covenant with the College that notwithstanding anything by the Commissioners done or knowingly suffered, the College paying the said rent, and performing and observing the covenants by the College hereinbefore contained, may quietly possess and enjoy the said premises and every part thereof during the said term without interruption or disturbance by the Commissioners, or any Corporation or person lawfully claiming through, under or in trust for them. IN witness, \&c. 


\title{
APPENDIX G.
}

\author{
(See Report, page 14.)
}

\section{Lease of the Site of the Alexandra House.}

This Indenture, made the Twenty-fifth day of December Onc thousand eight hundred and nimety-four, between the Commissioners for the Exhibition of 1851 (hercinafter called "the Commissioners") of the one part, and the Alexandra House Association, a Company registered under the Companies Acts, 1862 to 1890, and limited by guarantee (hereinafter called "the Association"), of the other part: WhEREAS Sir Francis Cook, of Doughty House, Richmond, in the County of Surrey, Baronet, of his privatc munificence, in the year One thousand eight hundred and eighty-three, devoted the sum of thirty thousand pounds for the purpose of providing homes for female students attending the various courses of instruction at Sonth Kensington, on the undertaking of the Commissioners to appropriate, in recognition of the munificence of Sir Francis Cook, a sitc for building such a home, but subject to such conditions as appear in this Indenture: And whereas the Commissioners in pursuance of such undertaking have appropriated on their estate at South Kensington the land coloured pink on the plan annexed to these prescnts as a site for such a home, and the building, called Alexandra House, has, out of thc said sum of thirty thousand pounds, and out of other money given with further munificence by the said Sir Francis Cook for the purpose, been erected upon that land, and suitably furnished for the purpose of such a homc. AND whereas the objects of the Association arc declared by the Memorandum of Association to be, amongst other things, "to accept from "the Commissioncrs for the Exhibition of 1851, a lease of Alexandra House, South

"Kensington, in the County of London, for the term of Nine hundred and ninety-nine "years, and containing such covenants and conditions as the Commissioners think "fit," and to use Alexandra House-

(i) As a home for female students who are attending a course of instruction at the Royal College of Music or the Science and Art Department's Classes, or at any other appropriate institution on the cstate of the Commissioner's at South Kensington, to be approved for the purpose jointly by the Commissioners and by the Council of the Association.

(ii) As a home for fcmale students who, having reccntly attended such course of instruction as aforesaid, are still continuing their education in science or art in the neighbourhood; and

(iii) If at any timc the whole Alexandra House is not rcquircd for the accommodation of such students as aforesaid as a home for any other fcmale students in science or art.

And whereas the Commissioners have agreed to grant to the Association such a lease, as in this Indenture appears: Now THIS INDENTURE wITNESSETH, that in consideration of the said agreement, and of the rent and covenants on the part of the Association hereinafter reserved and contained, the Commissioners hereby dcmise to the Association all that picce of land, situate on the estate of the Commissioncrs, 
at South Kensington, in the parish of Kensington in the County of London, together with the buildings erected on that land or part thereof (now known as Alexandra House), which premises are more particularly delineated on the plan annexed to these presents, and are thereon coloured pink, to hold the premises hereby demised unto the Association from the date of these presents for the term of nine hundred and ninety-nine years, at the yearly rent of five pounds, subject nevertheless to the covenants and conditions herein contained-that is to say :-

The Association doth hereby covenant with the Commissioners, their suceessors and assigns as follows:-

1. The Association will from time to time and at all times during the said term, pay and discharge all land tax, tithe rent charge, and all rates, taxes, charges, assessments and outgoings whatsoever, whether parliamentary, parochial, local or of any other deseription, which are now or may at any time hereafter be assessed, charged or imposed upon the premises liereby demised, or on the owner or oceupier in respect thereof, landlord's property or ineome tax only exeepted.

2. The Association will, during the said term, keep the premises hereby demised, and all additions erected on or made to the said premises, in good and tenantable repair and condition, externally and internally.

3. The Association will maintain and repair, to the satisfaction of the surveyor of the Commissioners, the road eoloured blue on the plan annexed to these presents, until the road is taken over by a public authority.

4. The Association will, at the determination of their tenancy, quietly yield up the premises hereby demised, together with all additions and improvements made thereto in the meantime, and all fixtures, which now are or at any time during the tenaney shall be thercon, in a good and tenantable state of repair and condition.

5. The Association will permit the Commissioners or their agents at any time to enter upon the said premises, and examine the state of repair and condition thereof, and will repair and make good all defects of which notice in writing shall be given by the Commissioners, within three months after the notice is given.

6. If the Association shall at any time make default in the performanee of any of the covenants hereinbefore contained for or relating to the repair of the said premises, the Commissioners may (but without prejudiee to the right of re-entry under the power hereinafter contained) enter upon the said premises and repair the same at the expense of the Association, in accordance with the covenants and provisions of these presents, and recover the expenses of such repairs (in ease the same shall not be repaid by the Association within one calendar month after notiee in that behalf given to the Association or left for the Association on the said demised premises) by distress or otherwise, as if the same had been rent in arrear reserved by these presents.

7. The Association will, during the said term, keep the said Alexandra House, and any buildings, ereetions and fixtures of an insurable nature, which may be placed on the land hereby demised, at any time during the said term, insured to the full value thereof, as determined by the surveyor of the Commissioners for the time being, in some insurance office of repute to be approved in writing by the Commissioners, and will when required produce to the Commissioners the poliey and receipt for the last premium in respect of such insurance, and if the Alexandra House or the buildings, erections and fixtures aforesaid are destroyed or damaged by fire the moneys received in respect of the insurance shall be laid out in rebuilding or 
reinstating the same, and in case these moneys are not suffieient for the purpose, the deficieney shall be made good by the Assoeiation.

8. The Assoeiation will not at any time, during the said term, without the lieence in writing of the Commissioners first obtained, ereet any new buildings on the land hereby demised, or make any struetural alteration or addition in or to the said Alexandra House or any buildings whieh may be ereeted during the said term upon the land hereby demised, and will obtain the approval of the Commissioners to the plans and specifieations of any intended buildings or alterations, a lieense for whieh may be obtained from the Commissioners, and ereet or. make the same in manner so approved.

9. The Assoeiation will earry out with due diligence the objects for which the Assoeiation is constituted, and will, during the said term, use and continue to use the Alexandra House and any buildings whieh may be ereeted on the land liereby demised for the purposes set out in their Memorandum of Association, and hereinbefore recited, and will constantly maintain the same in working order, and will not use the premises hereby demised or suffer the same to be used otherwise than for those purposes.

10. The Assoeiation will not assign, mortgage, elarge, transfer, underlet or part with the possession of the premises hereby demised, or any part thereof, without the previous consent in writing of the Commissioners.

11. The Commissioners, or any person or persons by them authorised in that behalf, may at any time enter upon the said demised premises for the purpose of eonstrueting, laying down, altering, repairing, eleansing, emptying or maintaining any sewers, watereourses, eesspools, gutters, drains, water-pipes, eleetrie wires or gas-pipes in eonneetion with or for the aceommodation of any adjoining property, doing as little damage as may be to the said premises hereby demised, and restoring the surface of the soil and everything ereeted thereon without any unreasonable delay, but without making eompensation for any temporary damage or ineonvenienee to the Association, so as no sueh sewer, watereourse, eesspool, gutter, drain, water-pipe, electrie wire or gas-pipe shall pass under or through the said premises hereby demised.

12. The Commissioners may at any time, during the said term use, ereet, rebuild or alter any land or buildings adjoining or near to the said demised premises for any purpose and in any manner they may think fit, notwithstanding that the same may obstruet or interfere with any right or light or other easement for the time being appertaining to or enjoyed with the said demised premises or any part thereof or any building for the time being thereon.

And the Commissioners hereby covenant with the Assoeiation that, if the Association perform and observe the several covenants, eonditions and agreements herein contained, and on the part of the Assoeiation to be performed and observed, the Assoeiation shall and may peaeeably and quietly hold and enjoy the premises hereby demised during the term hereby granted, without any lawful interruption or disturbance from or by the Commissioners or any persons claiming under or in trust for them.

AND IT IS HEREBY AGREED AND DECLARED, and these presents are on this condition, that if the Association shall at any time fail or negleet to perform and observe any of the covenants, eonditions or agreements herein contained, and on the part of the Assuciation to be performed and observed, or if an order be made, or an effeetive 
resolution be passed for the winding-up of the Association, or if at any time the number of membcrs is reduced below ninc, and remains so reduccd for the period of threc calendar months, after notice from the Commissioncrs requiring the number of members to be increased to nine, then, and in any such casc, the Commissioners or any person or persons duly autlioriscd by them in that bchalf, may re-enter into and upon the premises hereby demiscd or any part thereof in the name of the whole, and hold and enjoy the same theuccforth, as if thcsc prescnts liad not been made, without prejudicc to any right of action or remedy of the Commissioncrs in respect of any anteccdent breach of any of the coveuauts by the Association hereinbeforo containcd. In witness, \&c.

\section{APPENDIX $\mathrm{H}$.}

\section{(See Report, page 17.)}

\section{Lease of the Site of the Royal School of Art NeEdlework.}

This Indenture, made the 1st day of September 1901, between the Commissioners for the Exhibition of 1851, incorporated by Royal Charter dated the 15th day of August 1850, and hereinafter called the Lessors, of the one part, and the Royal School of Art Necdlework, incorporated under the Companies Act, 1862, and the Acts amending the same and hereinafter called the School, of the other part, WitNesseth, that in consideration of the School having ercetcd the building hereinafter demised, and of the yearly rents and covenants, conditious and agreements hereinafter reserved and contained, and on the part of the School to be paid, performed, and observed, the Lessors do hereby demise unto the School and their assigns ALL THAT piece of land situate at Kensington in the County of London, on the west side of Exhibition Road, with a frontage thereto of 118 feet 6 inches or thereabouts, and on the worth side of Imperial Institute Road, witl a frontage thereto of 149 feet 6 inches or thereabouts, and abutting wcst and north on other property of the Lessors, and more particularly described and delineated in the plan drawn hcreon, and therein coloured pink: Together with the building and all other erections erected and standing thereon, and together also with all the rights, members, easements and appurtenances to the said premises belonging, except and reserving unto the Lessors, their successors and assigns, such rights of building on and otherwise dealing with adjoining and neighbouring land, the property of the Lessors, their successors or assigns, as are hereinafter expresscd. And also except and reserving unto the Lessors, their successors and assigns, the subway under the premises hereby demised, the position whereof is indicated by the portion hatched in red on the said plan. And also except and reserving unto the Lessors, their successors and assigns, the free running of water and soil coming from any other buildings or land contiguous to the said premises in and through the sewers, drains, and watercourses upon or under the said premises. T'o HoLD the same unto the School and thcir assigns for the term of 999 years from the 24th day of June 1898, YieLding aND PaYing therefor for the first and second years of the said term the rent of a peppercorn, if demanded, and for the third and every subsequent year of the said term the yearly rcntal of $200 l$, and so in proportion 
for the period less than a year; AND ALSO YIELDING AND PA YING therefor for the first and every subsequent year of the said term (but subjeet to redemption as hereinafter provided) the redeemable yearly rent of $480 l$., and so in proportion for any period less than a year, sueh several rents (hereinafter colleetively referred to as " the rent") to be paid free from all deductions in respeet of sewers, rates, tithes, or tithe commutation, rent charge, and land tax (if any) and all other rates, taxes, charges, assessments, impositions, obligations, outgoings, whether Parliamentary, paroehial, or otherwise, whieh now are or at any time during the said term may beeome charged, imposed or payable upon or out of the said premises or any part thereof, or upon or by the Landlord or Tenant in respeet of the rent (exeept the Landlord's Property or Ineome Tax), and to be payable by equal quarterly payments on the 25 th day of Mareh, the 24 th day of June, the 29th day of September and the 25th day of Deember in every year, and the first quarterly payment of the said redeemable rent to be due and paid on the 29 th day of September 1901, and the first quarterly payment of the said rent of $200 l$. to be due and paid on the 29th day of September 1900: Axp the School do hereby for themselves and their permitted assigns, covenant with the Lessors, their suceessors and assigns, that they, the Sehool and their permitted assigns, will pay tho rent at the times and in manner aforesaid. AND also will from time to time, during the said term, pay all sewers, rates, tithes, and tithe commutation, rent eharge, and land tax (if any) and all other rates, taxes, charges, assessments, impositions, obligations, and outgoings, whether parliamentary, paroehial, or otherwise, which are now or at any time during the said term may beeome eharged or imposed or payable upon or out of the said premises or any part thereof, or upon or by the Landlord or School in respect thereof, or upon the rent (except the Landlord's Ineome or Property Tax). AND ALSO will at their own expense, as oecasion shall require during the said term, and without being required so to do, well and suffieiently repair, maintain, paint, pave, empty, cleanse, amend, and keep in such good and substantial repair as is necessary for the oeeupation of the School, or other the purposes for which the said premises are hereinafter authorised to be used, the buildings and ereetions now standing, and all future buildings and ereetions to be ereeted and built on the said piece of land and every part thereof respectively, and the same being in all things so well and sufficiently repaired, maintained, painted, paved, emptied, eleansed, amended, and kept as aforesaid, at the end or other sooner determination of the said term, will quietly yield up together with all things which at any time during the last ten years of the said term shall have been in any way fastened to the said premises or to any future ereetions to be made thereon, and may eome under the denomination of Landlord's fixtures, and moreover will permit the Lessors, their suecessors or assigns, and their respeetive Surveyor or Agents with or without workmen and others, at any reasonable hours in the daytime, during the last ten years of the said term, to enter upon the said premises and to take a Sehedule of all the fixtures and things to be yielded up as aforesaid, AND ALSO, with or without workmen and others, at reasonable hours in the daytime twiee or oftener in every year during the said term, to enter upon and examine the condition of the said premises and the buildings and ereetions for the time being thereon, and of all defects and wants of repair there found to give or leave notice in writing at the said premises, for the Sehool or their permitted assigns to repair the same within three calendar nionths next after sueh notice, and they will, so often as the same shall happen, and within sueh three calendar months, well and sufficiently repair and re-instate the premises aeeording to such notice. 
And moreover, that the School or thcir permitted assigns will once in every four years of the said term paint all the wondwork and ironwork belonging to the said premises, or to the buildings or crections for the time being standing thereon, with two coats of proper oil colours in a workmanlike manner, and in a like manncr will paint and paper once in every sevcn years of the said term the whole of the inside of the same premises and buildings (all such paintings to be done twicc in proper oil colours). And also will at proper timcs and from time to time during the said tcrm, as often as need shall requirc, pay a reasonable proportion of the expcnse of making, supporting, repairing, cleansing, lighting, watering, and amcnding all or any roads, pavements, channels, fences, party walls, wydraughts, gutters, sewcrs, and drains now or hereafter belonging to the said premises or any part thereof, or used thercwith in common with the other premiscs ncar or adjoining thereto, such proportion to be determined by the Surveyor for the timc being of the Licssors, their successors or assigns, and that in default of payment of such proportion the same shall be recoverable as rent in arrear under this demise. And also that the School and their permitted assigns shall not at any time makc any alterations whatcver in the elcvation or architectural exterior decorations of the said building, and promiscs hereby demiscd or any future erections to be built on the samc premiscs or any part thcreof, without the conscnt in writing of the Lessors, thcir successors or assigns, or thcir Surveyor for the time bcing, and shall not nor will erect or set up any additional ercctions or buildings in or upon any part of the said premises without the previons consent of the Liessors, their successors or assigns, or their Surveyor for the time being, and shall not nor will at any time cut or injure any of the principal timbers or walls of the buildings from time to time standing or being on the said premises. And also that the School or thcir permitted assigns will not without the consent in writing of the Lessors, their succcssors or assigns, use the said premises or any part thereof or any building or crection now erceted or hereaftcr to be erected thereon, for any purpose other than the purposes specified in the Memorandum of Association of the School, or as a School of Artistic Design, but this shall not permit the use of the same as a residence, except of an Officcr of the School having charge of the building, or of an ordinary caretaker, and shall not wittingly or willingly do or suffer to be done any act or thing on the said premises or any part thereof, which may grow to the annoyance, damage, or disturbance of the Lessors, their successors or assigns, or any Tenant or Occupier of any part of the Lstatc of the Lessors, their successors or assigns, at Kensington aforesaid. And also will permit the workmen of the Lessors, their successors or assigns, and the Tenants and Occupiers of the adjoining premises belonging to them, such tenants and occupiers having previously obtained the consent in writing of the Surveyor for the time being of the Lessors, their successors or assigns, to enter into the said premises for the purpose of repairing the adjoining premises, making reasonable compensation to the School or their permitted assigns for all damage occasioned thereby. AND MOREOVER, will insure the said building hereby demised forthwith, and all buildings and erections hereafter erccted on the said premises hereby demised or any part thereof, as soon as may be after the erection of such erections and buildings, in the names of the Lessors, their successors or assigns, either alone or jointly with the School or their permitted assigns to the amount of at least throe fourths of the value of the same several buildings and erections respectively, in the Alliance Insurance Office, or some other Fire Insurance Office in London or Westminster, to be from time to time nominated by the Lessors, their successors or assigns, and will keep the same respectively so insured during all the said term hereby granted: 
And will upon the request of the Lessors, their sueeessors or assigns, or any of them or any of their respective Stewards, Agents, or Reeeivers of rents for the time being, show the poliey or policies for sueh Insuranee, and the reeeipt or reeeipts given by or on behalf of sueh Offiee for the premium or premiums of sueh insurance for the then current year, and that if and so often as the said premises or any buildings or erections for the time being ereeted thereon shall be destroyed or damaged by fire, the moneys which shall be reeeived in respeet of every or any sueh Poliey shall be forthwith expended in repairing and rebuilding the premises to the satisfaetion of the Surveyor for the time being of the Lessors, their sueeessors or assigns, and if such moneys shall be insuffieient the deficieney shall be made good by the Sehool or their permitted assigns, and that if the several ereetions and buildings or any of them shall be burnt down or damaged by fire the Sehool or their permitted assigns shall nevertheless pay the rent, as if no sueh fire had happened : Axd also that the Sehool and their permitted assigns will not, during the said term, without the previous eonsent in writing of the Lessors, their sueeessors or assigns, underlet or part with the possession of, or mortgage, eharge or eneumber the said premises or any part thereof, or attempt or affeet so to do, but sueh eonsent shall not be withheld from an assignment by the Sehool or their permitted assigns to an ineorporated body formed for and earrying on purposes for which the said premises are hereinbefore authorised to be used, and laving a financial position not inferior to that of the Sehool at the date of these presents: And the School and their permitted assigns will at all times during the said term, within three calendar months after the date and exeeution of every or any permitted assignment of the said premises or any part thereof, for the whole then unexpired residue of the said term, give notiee in writing of sueh assignment, showing the date of sueh assignment and the premises comprised therein and the name and address of the person or persons to whom sueh assignment shall have been made, to the Lessors, their sueeessors or assigns, or their Agent for the time being, and will pay the fee of 10 s. for registering sueh assignment in the books of the Lessors, their sueeessors or assigns. Provided ALWAYS, and it is hereby agreed and declared, that there shall not be hereby implied a grant by the Lessors of any right of light or air in respeet of any building or ereetion ereeted or to be erected on the said pieee of land hereby demised by the Sehool or their permitted assigns, or any other rights exeept sueh as are hereby expressly granted or demised, and that the Lessors, their sueeessors or assigns, shall have power without obtaining any eonsent from or making any eompensation unto the Sehool, or their permitted assigns, to deal as they may think fit with all their other property in the neighbourhood of the premises hereby demised, and to ereet or suffer to be ereeted thereon any buildings whatsoever, and open any windows in the same, whether sueh buildings or any of them shall or shall not diminish the light or air whieh may now or at any time during the said term hereby granted, be enjoyed by the Sehool or their permitted assigns, or by the persons for the time being oeeupying the said premises hereby demised. Provided alWays, and these presents are upon this condition, that if the rent or any part thereof shall be unpaid for twenty-eight days after any of the days on whieh the same ought to be paid, although no formal or legal demand shall have been made thereof, or if there shall be any breach, negleet, or non-observanee, or non-performance of any of the eovenants and eonditions herein eontained, and on the part of the Sehool or permitted assigns to be observed or performed, then and in either of sueh eases it shall be lawful for the Lessors, their sueeessors or assigns, at any time thereafter to enter into and upon the said premises or any part therenf in the name 
of the whole, and thereupon the said term hereby granted shall absolutely determine: AND the Lessors do hereby, for thcmselves, their successors and assigns, covenant with the School and their permitted assigns, that they, paying the rent and performing and observing the covenants and conditions hereinbefore on their part contained, shall peaceably possess and enjoy the said premises liercby demised for the term hereby granted without any interruption by the Lessors, their successors or assigns, or any other person or persons lawfully claiming by, from, or under them, or any of them. And moreover, that it shall be lawful for the School or their permitted assigns at any time or times during the said term, on giving to the Lessors, their successors or assigns, not less than three calendar months' previous notice of their intention so to do, to redeem all or any part or parts of the redeemable rent hereinbefore reserved, by payment to the Lessors, their successors and assigns, of a capital sum or capital sums in the proportion of One hundred pounds for every $3 l$. of the said rent to be redeemed, and upon every or any such payment the amount of the said redeemable rent which shall be redcemed thereby shall cease and determine: Provided ALWAys, that no smaller part of such redeemable rent than the yearly sum of $15 l$. shall be redeemed at any one time. IN witness, \&c.

\section{APPENDIX J.}

(See Report, page 25.)

\section{The Imperial College of Science and Technology.}

Charter of Incorporation.

Edward VII. BY the Grace of God of the United Kingdom of Great Britain and Ireland and of the British Dominions beyond the Seas King Defender of the Faith

To alL to whom these Presents shall come Greetivg.

Whereas the Right Honourable Reginald McKenna President of the Board of Education has lately presented to Us in Our Council a humble Petition and thereby represented to Us-

Tна'т Our Government have signified their intention to make arrangements for placing at the disposal of the Governing Body of a new Institution of Science and Technology when incorporated by Royal Charter certain buildings at South Kensington now used or intended to be used for the purposes of the Royal College of Science and Royal School of Mines together with certain rights and subject to certain liabilities attaching thereto or connected therewith and any moneys provided by Parliament as a grant in aid of the cost of the maintenance and administration of the Institution

AND THAT the Royal Commissioners for the Exhibition of 1851 have resolved to appropriate for the purposes of such an Institution when so incorporated certain portions of their estate at South Kensington

AND THAT divers persons are prepared to make munificent contributions towards the establishment and suppor of such an Institution 
And THAT the City and Guilds of London Institute have undertaken that the Central Technical College of that Institute shall be an integral part of such an Institution when so incorporated subject to the fulfilment of the conditions set out in the Schedule hereto and shall so continue so long as those conditions or such other conditions as that Institute may desire or may agree to in place thereof are fulfilled

And whereas We have taken the said Petition into Our Royal consideration and are minded to accede thereto:

Now THEREFore know ye, that We by virtue of Our Royal Prerogative and of all other powers enabling Us in that behalf do of Our special Grace certain Knowledgo and mere Motion by these Presents for Us Our Heirs and Successors grant will direct and ordain as follows-

\section{ARTICLE I.}

\section{Establishment Name and Ixcorporation of the Imperial College of Science and Technology.}

There shall be and there is hereby established with its principal seat at South Kensington an Institution or Group of Associated Colleges with the name of the Imperial College of Science and Technology. By which name the members for the time being of the Governing Body hereinafter constituted shall be and are hereby created one body corporate with perpetual succession and a common seal With full power and capacity by and in such name To sue and be sued And to take and hold and subject to such consent as may be by law required to grant demise exchange or otherwise dispose of real or personal property And notwithstanding the Statutes of Mortmain without any further or other license by virtue of this Our Charter to take and hold land to the annual value of $50,000 l$. according to the annual value thereof at the time or times when the same shall be taken in addition to the value of the land for the time being occupied by or on behalf of the said Corporation for the transaction of its business and the actual carrying out of its purposes And to do all other lawful acts whatsoever. Which Institution shall have the constitution and powers and be subject to the regulations in this Our Charter prescribed and contained And which Institution is in this Our Charter referred to as " the Imperial College."

\section{ARTICLE II.}

\section{Purposes of the Imperial College.}

The purposes of the Imperial College are to give the highest specialised instruction and to provide the fullest equipment for the most advanced training and research in various branches of science especially in its application to industry and to do all or any of such other things as the Governing Body hereinafter constituted consider conducive or incidental thereto having regard to the provision for those purposes which already exists elsewhere And for these purposes the Governing Body subject to the provisions of this Our Charter shall carry on the work of the Royal College of Science and the Royal School of Mines and may establish Colleges or other Institutions or Departments of Instruction And any Institution or Department so established and (stibject as hereinbefore recited) the Central Technical College of the City and Guilds of London Institute shall be integral parts of the Imperial College And the said Central Technical College shall be hereafter called and known as and is hereinafter referred to as " the City and Guilds College." 


\section{ARTICLE III.}

Visitior.

We reserve to Ourselves to be the Visitor of the Imperial College through the President of the Board of Edueation.

\section{ARTICLE IV.}

\section{Constitution of Governing Body.}

The Governing Body of the Imperial College (hereinafter referred to as " the Governing Body") shall be constituted and shall when eomplete eonsist of forty members eaeh of whom shall exeept as otherwise herein provided be appointed for a term of office of four years as follows-

Six by Ourselves

Four by the President of the Board of Education

Five eaeh by the University of London the London County Couneil and the City and Guilds of Londoul Institute

Two by the Royal Commissioners for the Exhibition of 1851

One by the Royal Soeiety

Four by the Professorial Staff of the Imperial College-that is to say by the Prineipal Officer if not a Professor and the Professors-to be appointed in aeeordanee with regulations to be made for the purpose

One eaeh by the Institution of Civil Engineers the Institution of Mcehanieal Engineers the Institution of Elcetrieal Engineers the Iron and Steel Institute the Institution of Naval Architeets the Soeiety of Chemieal Industry the Institution of Mining Engineers and the Institution of Mining and Metallurgy

Provided that the first members of the Governing Body sliall be-

(1) The Right Honourable the Earl of Crewe, Lord President of Our Couneil ;

(2) The Right Honourable Gerald William Balfour ;

(3) The Right Honourable Sir Franeis Mowatt, G.C.B., I.S.O. ;

(4) Sir Julius Charles Wernher, Baronet;

(5) Sir William Henry White, K.C.B., LL.D., F.R.S. ;

(6) Donald MaeAlister, Esq., M.D., LL.D., D.C.L., Principal of the University of Glasgow ;

appointed by Ourselves:

(7) The Right Honourable Arthur Herbert Dyke Acland;

(8) Francis Grant Ogilvie, Esq., C.B., one of the Prineipal Assistant Seeretaries of the Board of Education;

(9) John Charles Gabriel Sykes, Esq., one of the Assistant Seeretaries of the Board of Edueation;

(10) Riehard Tetley Glazebrook, Esq., D.Se., F.R.S., Direetor of the National Physieal Laboratory ;

who shall be deemed to be appointed by the President of the Board of Edueation :

(11) Sir Edward Henry Busk, Chairman of Convoeation, and Past VieeChaneellor of the University of London;

(12) David Sing Capper, Esq., Professor of Engineering, King's College, London ;

(13) John Bretland Farmer, Esq., D.Se., F.R.S., Professor of Botany, Royal College of Science; 
(14) Sir Henry Enfield Roscoe, D.C.L., LL.D., D.Sc., Ph.D., F.R.S., Past Vice-Chancellor of the University of Iondon;

(15) Sir Arthur William Rücker, D.Sc., LL.D., F.R.S., Principal of the University of London;

who shall be deemed to be appointed by the University of London :

(16) Arthur Acland Allen, Esq., M.P. ;

(17) : Henry Perey Harris, Esq., Chairman of the London County Couneil ;

(18) Sir Clement Kinloeh-Cooke ;

(19) Richard Atkinson Robinson, Esq. ;

(20) Joln Thomas Taylor, Esq., I.S.O. ;

who shall be deemed to be appointed by the London County Council :

(21) The Right Honourable The Earl of Halsbury, F.R.S., Chairman of the Council of the City and Guilds of London Institute;

(22) Sir Joln Wolfe Wolfe-Barry, K.C.B., F.R.S. ;

(23) Sir Owen Roberts, D.C.L., LL.D., Clerk to the Worshipful Company of Clothworkers;

(24) Sir Walter Sherburne Pridenux, Clerk to the Worslipful Company of Goldsmithis ;

(25) Sir John Watney, Honorary Secretary of the City and Guilds of London Institute ;

who shall be deemed to be appointed by the City and Guilds of London Institute:

(26) Viseount Esher, G.C.V.O., K.C.B. ;

(27) Lientenant-Colonel Sir Arthur John Bigge, G.C.V.O., K.C.B., K.C.S.I., K.C.M.G., I.S.O. ;

who shall be deemed to be appointed by the Royal Commissioners for the Exhibition of 1851 :

(28) Sir Archibald Geikie, D.C.L., D.Se., LL.D., F.R.S., one of the Secretaries of the Royal Soeiety;

who shall be deemed to be appointed by the Royal Society:

(29) William Augustus Tilden, Esq., D.Se., F.R.S., Dean of and Professor of Chemistry in the Royal College of Seience;

(30) William Gowland, Esq., Professor of Metallurgy in the Royal School of Mines;

(31) William Ernest Dalby, Esq., Professor of Civil and Mechanical Engineering in the Central Technical College;

who shall be deemed to be appointed by the Professorial Staff of the Imperial College :

(32) Sir Alexander Blackie William Kennedy, LL.D., F.R.S., President of the Institution of Civil Engineers;

who shall be deemed to be appointed by the Institution of Civil Engineers :

(33) Tom Hurry Riches, Esq., President of the Institution of Mechanical Engineers ;

who shall be deemed to be appointed by the Institution of Mechanical Engineers :

(34) Robert Kaye Gray, Esq., a Past President of the Institution of Electrical Engineers ;

who shall be deemed to be appointed by the Institution of Electrical Engineers: 
(35) Sir Hugh Bell, Baronet, President of the Iron and Steel Institute; who shall be deemed to be appointed by the Iron and Steel Institute :

(36) Francis Elgar, Esq., LIL.D., F.R.S. ;

who shall be deemed to be appointed by the Institution of Naval Arehiteets:

(37) Edward Divers, Esq., M.D., D.Sc., F.R.S., a Past President of the Society of Chemieal Industry;

who shall be deemed to be appointed by the Soeiety of Chemieal Industry:

(38) Arthur Sopwith, Esq., a Past President of the Institution of Mining Engineers ;

who shall be deemed to be appointed by the Institution of Mining Engineers:

(39) Walter McDermott, Esq., a Past President of the Institution of Mining and Metalhurgy;

who shall be deemed to be appointed by the Institution of Mining and Metallurgy.

Any Nember of the Governing Body to whose name in the foregoing list an odd number is prefixed shall be deemed to be appointed for a term of office ending on the thirty-first day of May 1913 and any member to whose name in the said list an even number is prefixed shall bedeemed to be appointed for a term of office ending on the thirty-first day of May 1911.

As soon as the Governing Body think it desirable but not less than one year nor more than three years from the date of this Our Charter the Professorial Staff of the Imperial College shall appoint an additional member of the Governing Body subjeet to regulations made for the purpose provided that the person so appointed shall not be a person who was at the date of this Our Charter a Professor of the Royal College of Seienee or of the Royal School of Mines or of the Central Technieal Collegre of the City and Guilds of London Institute. The person appointed a member of the Governing Body under this provision shall be so appointed for a term ending on the thirty-first day of May 1911.

A easual vacaney oeeasioned by death resignation or otherwise shall be filled up as soon as eonveniently may be in the case of any member appointed by Ourselves by Ourselves and in any other ease by the person or body who appointed the member whose place has become vacant and the person appointed to a casual vacaney shall be soappointed for the remainder of the term of office of the person in whose place he is appointed.

Persons appointed to be members of the Governing Body need not be members of the body by which they are appointed.

A person appointed to be a member of the Governing Body shall be eligible for re-appointment at any time.

The aets or proeeedings of the Governing Body shall not be invalidated by any vacancy in their number.

There shall be a quorum when 16 Goveruors are present at a meeting and every matter shall be determined by the majority of the members of the Governing Body present and voting on the question. In ease of equality of votes the ehairman or person acting as ehairman shall have a seeond or easting vote.

The President of the Board of Edueation shall summon the first meeting of the Governing Body and shall make sueh arrangements for the purposes of that meeting as he thinks neeessary and the Governing Body shall be deemed to be duly constituted on the oceasion of that meeting. 


\section{ARTICLE V.}

\section{Powers and Functions of Governing Body.}

Subject to the provisions of this Our Charter the Governing Body shall have such powers of general supervision direction and control over the courses of education or any parts thereof followed in any Institution or Department of an Institution which is an integral part of the Imperial College as they consider essential to the proper correlation of the work of the Imperial College or to the purposes of the Imperial College 2s hereinbefore defined.

All funds which may hereafter be contributed or assigned for the purposes of the Imperial College or for the purposes of any Department thereof whether by way of grant from Imperial local or other public funds or by way of fees of students annual contribution donation bequest or otherwise howsoever shall be paid in the first instance to the Governing Body and subject to the provisions of this Our Charter may be expended invested or otherwise dealt with by the Governing Body for the purposes of this Our Clarter.

The Governing Body may if they consent be constituted trustees of any endowment the trusts of which are consistent with the provisions of this Our Charter.

The Governing Body shall determine the subjects of instruction to be respectively assigned to or undertaken by any Institution or Department of an Institution which is an integral part of the Imperial College.

The Governing Body shall appoint Professors and subject as aforesaid establish such staff (whether teaching examining administrative or otherwise) and make appointments to such offices or employments (whether permanent temporary or occasional) of for or in connection with the Imperial College as they think fit upon such terms remuneration and conditions as they determine.

The Governing Body shall award such diplomas or other certificates of distinction or proficiency to students of the Imperial College and subject to such regulations and conditions as they determine.

The Governing Body shall fix generally the scales of fees to be charged to students of the Imperial College for any courses of instruction thereat but may allow such exceptions thereto or such total or partial exemptions therefrom as they think proper Provided that the Governing Body shall admit without payment of fee as a student of the Imperial College in such Department thereof as the Board of Education select any person nominated by that Board as a Royal Exhibitioner or National Scholar on payment by the Board of the fee ordinarily required of a student in that Department.

The Governing Body shall from time to time consult not only expert members of their own body and of the teaching stafi but also other persons with practical experience of industrial requirements for the purpose of obtaining expert advice with regard to such particulars connected with any Department as the Governing Body may refer to them and may if they think fit appoint an Advisory Board for any Department or Group of Departments. The Advisory Board so appointed for any Department or Group of Departments shall include the members of the Committee if any to which functions of management in respect of that Department or Group of Departments are assigned.

The Governing Body may found and endow Fellowships Exhibitions Scholarships or other prizes.

Subject to ayreement with the Authorities of any College or other Institution 
the Governing Body may by resolution recognise that College or Institution or any Department thereof as being in association with the Imperial College for all or any of the purposes of this Our Charter but no such resolution shall be valid or operative until allowed by Us in Council.

The Governing Body shall hold at least four ordinary meetings in each year and shall publish a report of their proceedings annually.

The Governing Body shall make Regulations with respect to matters for which under this Our Charter provision is to be made by Regulations and subject to the provisions of this Our Charter may make further Rules Regulations or Byclaws with respect to the conduet of their proceedings or to the earrying into effect of all or any of the purposes or provisions of this Our Charter and such Regulations shall provide amongst other things for the establishment and constitution of a Finance Committee and for the payment of any sum exceeding 100l. only on the authority of that Committee.

The Governing Body may appoint an Executive Committee and may also appoint sueh other Committees not necessarily eonsisting of members of their own Body as they think neeessary and may delegate to any sueh Committee such of their powers or functions as they think fit.

\section{ARTICLE VI.}

\section{Royal School of Mines.}

One of the Departments of instruetion of the Imperial College shall provide specialised courses in Mining and Metalhurgy and that Department shall be ealled and known by the name of "the Royal School of Mines" and the Governing Body shall award the diploma of "Associate of the Royal School of Mines" to any student who completes such courses to the satisfaction of the Governing Body.

\section{ARTICLE VII.}

\section{Transitory Provistons.}

Subject to the provisions of this Our Charter the Governing Body shall appoint all Professors and other members of the Teaching Staff of the Royal College of Seience or of the Royal School of Mines and all other persons who are at the date of this Our Charter in any office or employment in or in eonnection with those Institutions or either of them to as nearly as praeticable the same offices or employments in or in connection with the Imperial College upon as nearly as may be the same terms and eonditions and the persons so appointed shall continue in sueh offiee or employment unless and until the Governing Body otherwise decide.

Subject to the provisions of this Our Charter the Governing Body shall make provision for the continuance of any person who is at the date of this Our Charter a student of the Royal College of Seience or of the Royal Sehool of Mines or of the City and Guilds College as a student of the Imperial College until the expiration of the period for which he would in the ordinary eourse have remained a student of those Institutions or any of them and for his attendanee at courses corresponding as nearly as may be to the courses which he would in the ordinary course have attended.

In the case of any student to whom (on aceount of the length of time for which he has before the establishment of the Imperial College been a student of the Royal College of Science) it appears to the Governing Body to be more appropriate to award 
the diploma of "Associate of the Royal College of Scienee" than any diploma or other certifieate of distinction or profieicney established by the Governing Body the Governing Body shall award that diploma accordingly.

\section{ARTICLE VIII.}

\section{Relations of the Imperial College with the University of Loxdon.}

Subject to eompliance with the Statutes of the University of London and pending the settlement of the question of the incorporation of the Imperial College with that University the Imperial College shall be established in the first instanee as a Sehool of the University.

The Governing Body shall enter into eommunieation with the University of London with regard to the co-ordination of the work of the Imperial College with the work of the University and its other Sehools and for the purpose of carrying out or ficilitating such eo-ordination may enter into such arrangements either by way of transferring or exelanging Departments of instruetion or otherwise and upon suel terms as may be agreed upon between the Governing Body and the University.

\section{ARTICLE IX.}

\section{Further Provisions.}

Neither sex nor opinions upon any religious subjects shall qualify or disqualify any person for membership of the Governing Body or for appointment to any office or employment or for admittance to any course of instruction or for any fellowship diploma or other eertifieate of distinetion or for any emolument in or in connection with the Imperial College.

Unless the eontext otherwise requires the Interpretation Aet 1889 shall apply to the interpretation of this Our Charter as it applies to the interpretation of an Act of Parliament so however that this Our Charter shall always be eonstrued and adjudged in the most favourable and beneficial sense for the best advantage of the Imperial College and the promotion of the objects of this Our Charter as well in all Our Courts as elsewhere any non-reeital mis-recital uneertainty or imperfection herein notwithstanding.

The Governing Body may by a resolution in that belalf passed at any meeting by a majority of not less than two-thirds of the members present and voting (being an absolute majority of the whole Governing Body) and confirmed at a meeting held not less than one month nor more than four months afterwards by a like majority alter amend or add to this Our Charter and suel alteration amendment or addition shall when allowed by Us in Couneil beeome effectual so that this Our Cliarter shall theneeforward continue and operate as though it had been originally granted and made aecordingly. This provision shall apply to this Our Charter as altered amended or added to in manner aforesaid.

Noreover We reserve to Ourselves power from time to time to alter amend or add to these presents by Supplemental Charter and in partieular thereby to declare or define more partieularly the purposes and seope of the Imperial College in relation to matters appertaining to the Biologieal Seienees and to make sucl provision in reference thereto as may thereupon appear expedient.

In witness whereof We have eaused these Our Letters to be made Patent. Witness Ourself at Westminster the Eighth day of July in the seventl year of Our Reign. 
SCHEDULE.

The following are the eonditions hereinbefore referred to in respeet of the City and Guilds College :-

(1) In determining the subjects of instruetion to be respectively assigned to or undertaken by any Institution or Department of an Institution which is an integral part of the Imperial College the Governing Body shall in the ease of the City and Guilds College aet only after consultation with the Committee of Management of that College.

(2) The Governing Body shall place annually at the disposal of the Committee of Management of the City and Guilds College-

1. Such funds as may have been specifieally assigned to them for the purposes of that College.

2. Such sum as may be determined by the Governing Body after consultation with the Committee of Management to represent a fair proportion of the total sum reeeived as fees from students of the Imperial College.

3. Such further sum as the Governing Body may determine.

(3) The staff of the City and Guilds College (exeept sueh meinbers thereof as are Professors of the Imperial College) shall be appointed by and be responsible to the City and Guilds of London Institute.

(4) For the purposes of the appointment of any Professor of the Imperial College whose work is chiefly coneerned with instruetion to be given in the City and Guilds College the Governing Body shall aet only after having reeeived and considered the recommendation of a Special Committee eonsisting of two nembers appointed by the Governing Body and three members appointed by the Committee of Management of that College.

(5) The City and Guilds College shall be managed by a Committee of Management appointed for the purpose by the City and Guilds of London Institute and subject to such powers of general supervision direetion and eontrol as are hereinbefore reserved to the Governing Body that Committee shall have power to manage the City and Guilds College as they think fit.

The Governing Body shall appoint five additional members upon the Committee appointed by the City and Guilds of London Institute as the Committee of Management of the City and Guilds College.

(6) Nothing in this Our Charter shall affeet the power of the Couneil of the City and Guilds of London Institute to award either of the diplomas of Associate or Fellow of the Institute.

By Warrant under the King's Sign Manual, 


\section{A'T THE COUR'T AT WINDSOR CASTLE,}

The 21st Day of Noveniber, 1908

Present,

\section{THE KING'S MOST EXCELLENT MAJESTY IN COUNCIL.}

Whereas by Article IX. of the Charter of the Imperial College of Science and Technology it is provided that :-

"The Governing Body may by a resolution in that behalf passed at any meeting by a majority of not less than two-thirds of the members present and voting (being an absolute majority of the whole Governing Body) and confirmed at a meeting held not less than one month nor more than four months afterwards by a like majority alter amend or add to this Our Charter and such alteration amendment or addition shall when allowed by Us in Council become effectual so that this Our Charter shall thenceforward continue and operatc as though it has been originally granted and made accordingly " :

And whereas the Governing Body of the said College did, on the 21th day of July, 1908 , in pursuance of the said power pass a resolution " that the Rector of the Imperial College of Science and Technology be ex-officio a member of the Governing Body of the College" :

And whercas the said resolution was confirmed at another meeting of the Governing Body, held on the 6th day of November, 1908, and has been submitted to His Majesty in Council :

Now, therefore, His Majesty, by and with the advice of His Privy Council, is pleased to allow the amendment of the Charter by the addition to Article IV. of the Rector of the Imperial College of Science and Technology as an ex-officio member of the Governing Body.

A. W. FITZROY.

\section{A'T THE COUR'T AT BUCKINGHAM PALACE,}

The, 28Th DaY of June, 1909.

\section{Present,}

\section{THE KING'S MOST EXCELLENT MAJESTY IN COUNCIL.}

Whereas by the Charter of the Imperial College of Science and Technology it is, amongst other things, provided that, subject to agreement with the authorities of any College or other Institution, the Govcrning Body may by resolution recognise that College or Institution or any Department thereof as being in association with the Imperial College for all or any of the purposes of the Charter, but no such resolution shall be valid or operative until allowed by His Majesty in Council :

And whereas the University of Sheffield and the Imperial College have agreed as to the conditions under which association is to take place: 
And whereas the Governing Body of the Imperial College did, on the 2nd day of April, 1909, adopt the following Resolution :-

"That the Metallurgical Department of the University of Sheffield be recognised as being in assoeiation with the Imperial College of Science and Technology for the advanced metallurgy of iron and steel, as provided for in the Charter, Artiele V., and in accordance with the Minutes of the Governing Body respecting Associated Colleges" :

and have submitted the said Resolution for allowance by His Majesty in Council :

Now, therffore, His Majesty, having taken the said Resolution into eonsideration, is pleased by and with the advice of His Privy Council, to allow the same.

A. W. FITZROY.

\section{AT THE COURT AT ST. JAMES'S,}

The 19th Day of July, 1910.

Present,

\section{THE KING'S MOST EXCELLENT MAJESTY IN COUNCIL.}

Whereas by Charter dated the 8th day of July in the seventh year of the Reign of His late Majesty King Edward the Seventl after reciting :

that the Right Hon. Reginald MeKenna the then President of the Board of Education had lately presented to His Majesty in Couneil a humble Petition and thereby represented amongst other things that the City and Guilds of London Institute (hereinafter referred to as "the Institute") had undertaken that the Central Technieal College of the Institute (hereinafter referred to as "the City and Guilds College") should be an integral part of the Imperial College of Scienee and Teehnology when incorporated subject to the fulfilment of the conditions set forth in the Schedule to the said Charter and should so eontinue an integral part of the same as long as those eonditions or sueh other eonditions as the Institute might desire or agree to in place thereof should be fulfilled

the Imperial College of Science and Teehnology (hereinafter referred to as " the Imperial College ") was established and incorporated :

And Whereas by Article II. of the said Charter it was provided that (subject as reeited in the said Charter) the City and Guilds College should be an integral part of the Imperial College and should be thereafter ealled and known by that name:

And Whereas by Article IX. of the said Charter it was provided that the Governng Body of the Imperial College (hereinafter called "the Governing Body") might by a resolution in that behalf passed at any meeting by a majority of not less than two-thirds of the members present and voting (being an absolute majority of the whole of the Governing Body) and confirmed at a meeting held not less than one month nor more than four months afterwards by a like majority alter amend or add to the said Charter and that such alteration amendment or addition should when allowed by His Majesty in Council beeome effectual so that the said Charter should thenceforward 
continue and operate as though it has been originally granted and made accordingly and that the now reciting provision should apply to the said Charter as altered amended or added to in manner aforesaid:

Axd Wrereas the said Charter was amended by a resolution of the Governing Body duly passed on the 2ttl day of July 1908 and confirmed on the 6th day of November 1908 and such amendment was allowed by His late Majesty in Council on the 21st day of November 1908 :

And Whereas the Institute desire and have agreed to the conditions which are set forth in the Schedule hereto in place of the conditions set forth in the Schedule to the said Charter :

And Whereas a resolution was passed at a meeting of the Governing Body held on the 13th day of May 1910 by a majority of not Iess than two-thirds of the members present and voting (being an absolute majority of the whole of the Governing Body) that the said Charter be altered amended and added to by substituting the conditions which are set forth in the Schedule hereto for the conditions set forth in the Schedule to the said Charter :

AND Whereas the said resolution was confirmed at a meeting of the Governing Body held on the 8th day of July 1910 by a like majority :

And Whereas such alteration and amendment of and addition to the said Charter have been submitted to His Majesty in Council :

Now Therefore His Majesty by and with the advice of His Privy Council is pleased to allow the said alteration and amendment of and addition to the said Charter.

ALMERIC FIT'ZROY.

\section{SCHEDULE TO THE FOREGOING ORDER IN COUNCIL.}

1 The City and Guilds College shall include the whole of the Engineering Department of the Imperial College.

2 (I.) The City and Guilds College shall be under the immediate control of a Delegacy (hereinafter called "the Delegacy") which shall be constituted and when complete shall consist of nineteen members to be appointed as follows :-

Eight by the Governing Body from their members.

Eight by the Institute from their members.

Three by the Wardens and Commonalty of tho MIystery of the Goldsmiths of the City of London (hereinafter called "The Goldsmiths' Company").

Provided that the first members of the Delegacy shall be :-

1. The Right Honourable Sir Francis Mowatt, G.C.B., I.S.O.

2. Sir William Henry White, K.C.B., LL.D., F.R.S.

3. The Right Honourable Arthur Herbert Dyke Acland

4. Francis Grant Ogilvie, Esq., C.B.

5. Richard Atkinson Robinson, Esq.

6. William Cawthorne Unwin, Esq., B.Sc., LL.D., F.R.S.

7. Robert Kaye Gray, Esq., M.I.E.E.

8. The Rector of the Imperial College

who shall be deemed to be appointed by the Governing Body. 
9. The Right Honourable The Earl of Halsbury, F.R.S.

10. The Right Honourable The Earl of Selborne, K.G., G.C.M.G.

11. Sir John Wolfe Wolfe-Barry, K.C.B., F.R.S.

12. Lewis Boyd Sebastian, Esq.

13. Alpheus Cleophas Morton, Esq., M.P.

14. Sir Edward Henry Busk, M.A., LL.B.

15. Sir Owen Roberts, D.C.L., LL.D.

16. Sir John Watney

who shall be decmed to be appointed by the Institute.

17. Sir Walter Sherburne Prideaux

18. Sir Arthur William Rücker, D.Sc., LL.D., F.R.S.

19. Sir Boverton Redwood, D.Sc.

who shall be deemed to be appointed by the Goldsmiths' Company.

(II.) Every member of the Delegacy to whose name in the foregoing list an odd number is prefixed shall be deemed to be appointed for a term of office ending on the 31st day of August 1914 and every member to whose name in the said list an even number is prefixed shall be deemed to be appointed for a term of office ending on the 31st day of August 1916. Except as herein otherwise provided members of the Delegacy hercafter appointed shall hold office for four years.

(III.) The members of the Delegacy hereafter appointed by the Institute shall include such Representatives of the Institute on the Governing Body as may be willing to serve as members of the Delegacy.

(IV.) It shall not be necessary for the three representatives of the Goldsmiths' Company on the Delegacy to be members of the Goldsmiths' Company.

(V.) A easual vacancy on the Delegacy oceasioned by death resignation or otherwise shall be filled up as soon as conveniently may be by the body who appointed the member whose place has become vaeant and the person appointed to a casual vacancy shall be so appointed for the remainder of the term of office of the person in whose place he is appointed.

(VI.) A person appointed to be a member of the Delegacy shall be eligible for reappointment at any time.

(VII.) The acts or proceedings of the Delegacy shall not be invalidated by any vacancy in their number.

(VIII.) There shall be a quorum when six members of the Delegacy are present at a meeting and every matter shall be determined by the majority of the members of the Delegacy present and voting. In case of equality of votes the Chairman shall have a second or casting vote.

(IX.) The Secretary of the Imperial College shall summon the first meeting of the Delegacy and shall make such arrangements for the purposes of that meeting as he thinks necessary.

3 Subject to the provisions herein and in the said Charter contained :-

(I.) The Delegacy shall be entrusted with the preparation and issue of the programmes advertisements and announcements of the City and Guilds College.

(II.) The Delegacy shall appoint such Professors and establish such staff (whether teaching examining administrative or otherwise) and make such appoint- 
ments to such offices or employments (whethcr permanent temporary or occasional) of for or in connection with the City and Guilds College as they think fit upon such terms remuneration and conditions as they determinc. The Professors Members of the Staff and other persons so appointed sliall be directly responsible to and liable to be dismissed by or otherwise dealt with by the Delegacy.

(III.) All fees payable by Students of the City and Guilds College shall be paid in the first instance to the Delegaey and shall be transmitted by the Delcgaey to the Governing Body.

(IV.) The Delegacy slall have power to arrange for a separate banking account for the purposes of the financial arrangements contemplated by this Schedule.

(V.) The Delegaey may appoint such Committecs as they think necessary and may delegate to any of such Committees such of their powers or functions as they think fit.

(VI.) The Delegaey shall cause minutes of their resolutions and proceedings (and the resolutions and proceedings of any Committee appointed by them) to be made in a book or books provided for that purpose and such minutes shall from time to time be communieated to the Governing Body and to the Executive Committee of the Institute (hereinafter called "the Exccutive Committce ") and both of those bodies shall at all times have access to the records of the Delegacy and shall have powcr to call for reports from the Delegacy and to make such independent investigations as they or either of them shall decm fit.

(VII.) The Delegacy may make Rules Rcgulations or Byelaws with respcet to the eonduct of their proceedings or to the earrying into effect of all or any of the purposes or provisions of this Schedule.

(VIII.) The accounts of the Delegacy shall be audited by the Auditor of the Imperial Collcge.

4 Subject to the powers of the Delegacy the general supervision of the work of the City and Guilds College shall reside with the Rector of the Imperial College as Rector of the College of whiel the City and Guilds College forms an integral part.

5 All contracts cntercd into and acts done by or under the authority of the Delegaey in relation to the City and Guilds College shall be deemed to be cntered into and done by the Delegaey for and on behalf of the Imperial Collegc. In any legal proceedings in connection with the City and Guilds College the Impcrial Collegc shall so far as practicable act in consultation with the Delegaey and as bctween the Impcrial College and the Institute both bodies shall be jointly liable for all acts of the Delegacy in respect of the City and Guilds College.

6 (I.) On or before the 30th day of November in each year the Delegacy shall present to the Governing Body and to the Executive Committee a Rcport on the work of the past ycar. The Delegacy shall in such Annual Report after consultation with the Reetor of the Imperial College make such proposals as may be nccessary for the co-ordination of the work of the City and Guilds College with the other Departments of the Imperial College.

(II.) The Governing Body and the Exeeutive Committee shall within two months 
of the rcceipt of the Annual Report transmit to each other such comments or suggestions as they may respectively desire to makc with regard to such Report,

(III.) If the Governing Body and the Exccutive Committee concur in such Report or if no such comments or suggestions as aforesaid are received by either of them within the specified time or if within one month after receiving such comments or suggestions the Governing Body or the Executive Committee as the case may be concur therein or do not dissent therefrom the Govcrning Body shall forthwith proceed to issuc to the Delegacy instructions for the co-ordination of the work of the City and Guilds College with the other departments of the Imperial College in accordance with such Report and such comments and suggestions (if any).

7 (I.) On or before the 30th day of April in each ycar the Delegacy shall present to the Governing Body and to the Executive Committce a budget and scheme of work proposed for the following year.

(II.) The Governing Body and the Executive Committee shall within one month of the receipt of such budget and scheme transmit to each other such comments or suggestions as they may respectively desire to make with regard to the said budget and scheme.

(III.) If the Governing Body and the Exccutive Committec concur in such budget and scheme or if no such comments or suggestions as aforcsaid are received by either of them within the spccified time or if within onc month after receiving sucl comments or suggestions the Governing Body or the Executive Committee as the case may be concur therein or do not dissent therefrom the Governing Body shall forthwith proceed to issue to the Delegacy instructions for the work and expenditurc of the following year in accordance with such budget and scheme and such comments and suggestions (if any).

(IV.) If additional expenditure be necded during the year the Delegacy shall report to the Governing Body who shall authorize disallow or partially sanction such expenditure as they may think fit provided always that if such proposed additional expenditure cxceeds the sum of $£ 100$ the Delegacy shall also report to the Executive Committec and the Governing Body shall not act upon such report until one month after such report has been forwarded to the Executive Committee or the Executive Committee have cxpressed thcir concurrence therein.

8 If the Governing Body or the Executive Committee dissent from such comments or suggestions as the other of them may from time to time make under the provisions of paragraphs (5) or (6) of this Schedule the provision as to conference between the Governing Body and the Executive Committee set forth in the next paragraph shall forthwith apply.

9 The Governing Body and the Executive Committee shall at the request of either confer at any time on matters connected with the City and Guilds College.

10 Any difference or dispute between the Governing Body and the Executive Committee after such Conference shall be referrcd to a Court of Arbitrators consisting of the Chairman of the Governing Body the Chairman of the Council of the Institute and the President of the Royal Society or their respective nominees.

11 The Institute shall place at the disposal of the Governing Body:

(A) The continued use of the City and Guilds College buildings subject to the performance by the Governing Body of the covenants and conditions in the 
lease from the Commissioners for the Exhibition of 1851 under which the ground and premises are held or any modification thereof.

(B) An annual grant of $\mathfrak{E 5}, 000$.

Provided always that such buildings and annual grant of $\mathfrak{£ 5}, 000$ shall be used by the Imperial College exclusively for the purposes of the City and Guilds College.

12 The Governing Body shall in every year allocate to the Delegacy for the carrying on of the work of the City and Guilds College during the ensuing year :

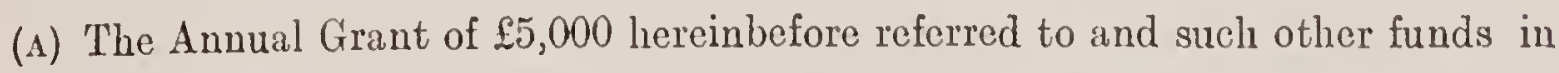
the nature of revenue as may liave been specifically assigned to the Governing Body for the purposes of the City and Guilds College.

(k) Such sum as may be determined by the Governing Body after consultation witl the Delegacy to represent a fair proportion of the total sum received as fees from Students of the Imperial College.

(c) Such further sum if any as the Governing Body may determine and as may be necessary for the adequate maintenance of the City and Guilds College.

13 There shall be a Board of Studies of the Imperial College consisting of the Professors of all such Colleges as are or may become integral parts of the Imperial Collego including the City and Guilds College. The Rector of the Imperial College shall be ex officio Chairman of the Board of Studies. The Board of Studies shall from time to time make such suggestions to the Governing Body or the Delegacy as they consider essential to the proper correlation of the work of and discipline in the various Institutions or Departments which are or shall become integral parts of the Imperial College.

14 (I.) There shall be a separate Board to be called "The Engineering Board" consisting of the Rector of the Imperial College and such members of the Board of Studies of the Imperial College as shall be Professors of the City and Guilds College. The Rector of the Imperial College shall be ex officio Chairman of the Engineering Board and a Vice-Chairman to whom the title of Dean of the City and Guilds College shall be given shall be elected by the members of the said last mentioned Board.

(II.) The Engineering Board shall act as an advisory Board to the Board of Studies of the Imperial College on all matters in connection with the City and Guilds College.

(III.) All matters of discipline arising in connection with the students of the City and Guilds College shall in the first instance be dealt with by the Dean of the City and Guilds College who shall be responsible to the Rector of the Imperial College for all such matters of discipline.

15 The Delegacy may at any time after consultation with the Rector of the Imperial College report to the Governing Body on such subjects connected with the City and Guilds College as they may think desirable.

16 Nothing in this Schedule shall affect the power of the Council of the Institute to award either of the diplomas of Associate or Fellow of the Institute. 


\title{
APPENDIX $K$.
}

\author{
(See Report, page 25.)
}

\section{Lease of Sites to Imperial College of Science and Technology.}

This Indexture, made the 20th day of October 1909, between the Commissioners for the Exhibition of 1851 (hereinafter called "the Commissioners") of the one part and The Imperial Collegc of Science and Technology (hereinafter called "the Imperial College") of the other part: Whereas the Impcrial College has bcen incorporated for the purposes and with the powcrs specificd in a Charter of Incorporation, granted by His Majesty and dated the 8th day of July 1907: Now THIS Indexture WITNESSETH, that in consideration of the rent hereinafter rescrved and of the covenants and conditions hereinafter contained, and on the part of the Imperial College and their successors to be observed and performed, the Commissioncrs do demise unto the Imperial College and their successors: ALL THOSE four picces or parccls of land a butting on to Prince Consort Road in the Parish of St. Margaret, Westminster, in the County of Middlesex, which, with the approximatc dimensions and boundarics thereof, are more particularly described in the plan drawn in the margin hercof, and therein coloured pink: Together with the right for the Imperial Collcge and all persons authorised by them or by the Commissioners in common with all persons having the like right at all timcs hereafter and for all purposes, with or without horscs, carts, carriages, or other vehicles, to pass and repass over and along the roadways shewn on the said plan, and thereon colourcd brown and marked respectively "Private Roadway" and "Roadway in common": And togcther also with the right for the Imperial College to build over the said roadway marked "Roadway in common" on the said plan: And together also with the right of ingress and cgrcss to and from the piece or parcel of land hereby demised, situate on the north side of Prince Consort Road, from and to the Royal Albert Hall Terrace, except and always reserved unto the Commissioners, thcir successors and assigns, lessces and othcr tenants, free passage and running of water and soil coming or to come from any other land or buildings of the Commissioncrs, their successors or assigns, adjoining or near to the premises hereby demiscd or any or either of them, in and through the channels, drains, sewcrs, and watercourses bclonging or appertaining thcreto, and cxcept and reserved unto the Commissioners and the Corporation of the Royal Albert Hall, and for the workmen of the Commissioners or the Corporation of the Royal Albert Hall, at all reasonable times to comc into and upon the said premises or any part thereof, to clcanse or repair the chimney shaft to be erected by the Imperial Collcge in accordance with the covenant hereinafter contained: To HOLD the said hereby demised premises unto the Imperial College and their successors from the date hereof for the term of 999 ycars, thence next ensuing: YIELDING AND PAYING therefor during the said term the rent of $5 l$. per annum, payable on the day of the cxpiration of each year of the said term hercby granted: And the Imperial College for themsclves, their successors and assigns, hereby covenant with the Commissioners and their successors to pay the said yearly rent hereby reserved, and also all rates, taxes, duties, charges, and assessments from time to time payable for and in respect of the said premises. And further that the Imperial College will, within seven years from the date herenf, or such longer period as may be 
agreed between the parties, ereet, build and complete on the scveral premises hereby demised, buildings suitable for additional purposes as may hereafter be defined by Charter or otherwise, together with the fixtures and fittings necessary or desirable for adapting the same for the purposes aforesaid, and that the aggregate sum to be expended by the Imperial College under this eovemant shall be not less than the sum of $250,000 l$., and that sueh buildings shall be ereeted in aecordanee with elevations which shall have first been submitted to and approved by the Commissioners, and in like manner no alterations shall be made in the elevation of the buildings, when ereeted, without such eonsent as aforesaid, and as regards the buildings to be erected on the north frontage of the plot of land adjoining the Courtyard of the Royal Albert Hall, the same shall not extend beyond such line as may be approved by the Commissioners. And also that, subject to the consent of the Corporation of the Royal Albert Hall and all other necessary parties being obtained, the Imperial College will at their own expense in ereeting the buildings proposed to be ereeted on the pieee or pareel of ground hereby demised, situate to the north of Prinee Consort Road, ereet, complete and finish, fit for use as part of sueh building, a ehimney shaft on the north side of the building of similar eapacity to the ehimney shaft now standing there, and used by the Corporation of the Royal Albert Hall, and will make all necessary connections with the flues belonging to the Corporation of the Royal Albert Hall from sueh new 5himney shaft, and will, when sueh flues have been conneeted and sueh shaft erected to the satisfaetion of the Commissioners and their lessees, demolish the said existing chimney shaft and make good the roadway where the same is now standing. And also that the Imperial College will at all times, during the eontinuanee of this demise, maintain the building or buildings for the time being standing on the said premises in a fit and proper state of repair for the purposes of the Imperial College, or sueh altered, amended, or additional purposes as may hereafter be defined by Charter or otherwise, and that the said demised premises and the buildings ereeted thereon shall be used for the purposes aforesaid, and for no other purposes without the consent of the Commissioners, their suceessors or assigns. And also that the Imperial College will, during the eontinuance of the said term, insure and keep insured the buildings, so to be erected as aforesaid, from loss or damage by fire in not less than two-thirds of the full value thereof. And also will at all times during the said term bear and pay all eosts and expenses, payable either by Landlord or Tenant in respeet of the premises hereby demised, of making, repairing, maintaining, rebuilding, and cleansing all ways, roads, pavements, sewers, drains, pipes, watereourses, fenees or other convenienees which shall belong to or be used with the said premises hereby demised, and in particular will repay to the Commissioners a fair proportion of the expense of making up the roads on the north side of the plot of land liereby demised, whieh is situate to the north of the Prince Consort Road, with a view to the same being taken over by the City of Westminster, and will keep the Commissioners indemnified against all such eosts and expenses as aforesaid: Provided ALWAYs that if the rent hereby reserved shall be in arrear for 28 days, or if the Imperial College shall not observe the covenants herein eontained or any of them, then and in any of such eases it shall be lawful for the Commissioners, their sueeessors or assigns, to re-enter the said demised premises, and thereupon the said term hereby granted shall absolutely cease and determine. And the Commissioners do hereby for themselves, their successors and assigns, eovenant with the Imperial College that they, the Imperial College, paying the said yearly rent of $5 l$, and performing and observing all the covenants hereinbefore 
contained, and on its part to be performed and observed, shall and may peaceably and quietly hold the said premises hereby demised, during the term hereby granted, without any evietion or disturbanee by the Commissioners, their sueeessors or assigns, or any person or persons lawfully or equitably elaiming by, from, or under them. As witness the respeetive Common Seals of the parties hereto the day and year first above written.

\section{APPENDIX L.}

\section{(See Report, page 26.)}

\section{Memorial to the President of the Board of Education in Favour of the Provision of more suitable Accomirodation for the National Science Collections.}

To the RIGHT HON. WALTER RUNCIMAN, M.P.,

President of the Board of Education.

Sir,

We, the undersigned, being deeply interested in the praetice and progress of British Seienee, desire to bring before you the importanee of the proper housing of the Science Colleetions at South Kensington. The permanent buildings now ereeted provide aecommodation for Art Collections only; to eomplete the seheme a suitable building for the Scienee Collections is a neeessity. The formation of a Scienee Museum representative of all branehes of physieal seienee, both pure and applied, has long engaged the attention both of the Government and of British seientific men. So long ago as 1874 the Duke of Devonshire's Commission on Seience strongly reeommended the establishment of sueh a Museum and in their fourth Report the Commissioners state :-

"While it is a matter of eongratulation that the Britisl Museum eontains one of the finest and largest collections in existenee illustrative of Biological Seienee, it is to be regretted that there is at present no National Colleetion of the instruments used in the investigation of Meehanieal, Chemieal or Physieal Laws, although sueh collections are of great importanee to persons interested in the Experimental Seienees.

"We consider that the reeent progress in these Seienees and the daily inereasing demand for knowledge eoneerning them make it desirable that the National Collections should be extended in this direetion, so as to meet \& great seientifie requirement which eannot be provided for in any other way." 
Since these words were written a National Science Museum has been established and the collections in it lave been steadily enriched by many important acquisitions. These collections are at present housed in the old buildings at Sonth Kensington known as the Sonthern Galleries and the Western Galleries. They now include models and copies of historical and modern philosophical apparatus of the greatest value to all interested in the progress of Britislı Science, and a large number of machines, instruments and models of great interest as illustrating the origin and development of our most pregnant British inventions, together with such special collections as the unique serics of models illustrating the history of ship-building.

In 1876 the Royal Commissioners of the Exhibition of 1851 offered to the Government of the day a sum of $£ 100,000$ together with a site on the Commissioners' ground for the proper housing of this collection, under the condition that the Government should undertake its maintenance. In 1878 the Commissioners repeated their offer and in 1879 this was declined by the Government. In 1890 the land to the south of Inperial Institute Road, reaching to that conveyed to the Government in 1864 for the erection of the Natural History Museum and containing $4 \frac{1}{2}$ acres, was sold to the Govern. ment for $£ 70,000$. This land has now been in part permanently allocated to the main seetion of the new buildings of the Imperial College of Science and Technology and to the building in course of erection for the Meteorological Office and a Post Office. The remainder of the site is at present occupied partly by temporary buildings and partly by the old buildings-the "Southern Galleries"-which now afford accommodation for the Machinery and Naval Architecture Collections of the Science Musenm. This portion of the site, adjoining as it does on the North the Imperial College and on the South the Natural History Musemm, is well regarded as an ideal position for the long projected Science Muscum, which would complete the magnificent group of Museum buildings already erected at Soutl Kensington.

The cost of acquisitions for the current growtl of such a Science Museum, it may be noted, is far less than that of a corresponding Art Museum. The value of Art produets increases rapidly with age, whereas the scientific implements, machinery and apparatus, interesting from a historical point of view, lave rarely any great commercial value. The Art Collections of the Vietoria and Albert Museum are now in possession of splendid buildings. If the buildings provided for the Science Collections were equally worthy of the interests which they should serve, the objects now in the Musemm could be exhibited to much greater advantage. Horeover, those lacunx which mark sections of recent activity in discovery and invention would be more readily filled than they can be while the obvionsly temporary character of the aecommodation suggests to those who hold objects of interest in the history and advance of Science that the anthorities have but little appreciation for sueh things.

Other eountries, notably France and Germany, have recognised the importance of preparing suitable buildings for their national Science Museums. In Paris the Museum of the Ecole des Arts et Metiers lias a world-wide renown; and a national German Seienee Museum is now being built in Munich at the cost of $£ 300,000$. England, the mother of so many great inventions that have proved to be pioneers in industrial Arts, stands alone in having made no adequate provision for cxlibiting and arranging in proper order her unique collections.

The undersigned venture to urge upon you that the time has now arrived for action. Land sufficient for the purpose is in the Government's hands and the Royal 
Commissioners of ' 51 if approached by the Government with a definite building scheme would doubtless give it due consideration. The need is great and the mass of British Science workers will hail your favourable decision with gratitude.

\section{Names of Signatories, with Titles and Official or Professional Position, in Alphabetical Order.}

ABNey, Str William de W., K.C.B., D.C.L., D.Se., F.R.S.

Adans, W. Gryul.s, M.A., D.Se., F.R.S., Late Professor of Natural Philosophy.

All.butt, Str T. Clifford, K.C.B., M.A., M.D., F.R.S., Regius Professor of Plyysic in the University of Cambridge.

Allerton, The Rt. Hon. Lord, F.R.S., LL.D.

Alverstone, The Rt. Hox. Lord, G.C.M.G., F.R.S., Lord Chief Justiee of England,

Axsox, Sir Williakr, Bart., M.P.

Armstrona, Henry E., Ph.D., LL.D., F.R.S., V.P.C.S., Professor of Chemistry, City and Guilds Institute, S. Kensington.

Aspinalu, Join A. F., President of the Institute of Meelanieal Enginecrs.

Averury, RT. Hox. Lord, LL.D., MI.D., F.Z.S., F.R.S., T.G.S.

BAKER, H. B., M.A., D.Se., F.R.S., Lee's Reader in Chemistry, Oxford.

BALFOUR OF BURLEIGH, LORD, K.T.

Ball, Str Robert S., M.A., LI.D., F.R.A.S., M.R.I.A., F.R.S., Lowndean Professor of Astronomy and Geometry, Cambridge.

Barlow, Sir 'I'Homas, M.D., F.R.S., Physieian to His Majesty's Houselıold, and to University College Hospital.

Bedson, P. Phillips, M.A., D.Se., B.Se., Professor of Chemistry, Armstrong College, Neweastle-upon-Tyne.

Beilby, George T., LL.D., F.R.S., President of the Institute of Chemistry of Great Britain and Ireland.

Beld, Sir Hugh, Bart., President of the Iron and Steel Institute.

Berkeley, The Earl of, F.R.S.

Boddingtox, Str Nathan, Viee-Chaneellor of the University of Leeds.

Bone, William A., D.Se., F.R.S.. Professor of Applied Chemistry, University of Leeds.

Bonney, Rev. T. G., Se.D., LL.D., T.R.S., D.Śc. Ph.D., Emeritus Professor of Geology, University College, London.

Bovey, Hexry J.. T.R.S., M.A., Reetor of the Imperial College of Seienee and Technology.

Boys. C. V.. A.P.S.Mr., F.R.S., Metropolitan Gas Referee, late Assistant Professor of Physics, Royal College of Seienee, S. Kensington.

Bradford, Johx Rose, M.D., D.Se., F.R.S., Seeretary of the Royal Society ; Professor of Medieine at University College. London.

Brown, Alexander Crum, M.D., D.Se., LI.D., F.R.S., Past President of Chemieal Society ; Emeritus Professor of Chemistry, University of Edinburgh.

Brows, Horace T', LL.D., F.I.C., F.G.S., F.L.S., F.R.S.

BrunNer, The RT. Hox. Str John, ir.P.

Brunton, Sir Lauder, Bart., M.D., LL.D., D.Se., F.R.C.P., F.R.S.. Consulting Physician to St. Bartholomew's Hospital.

Butcher, S. H., Litt.D., M.P., President of the British Academy.

Callendar, Hugh L., M.A., LL.D., F.R.S., Professor of Physies, Imperial College of Seience and T'eehnology.

Christte, Sir W. H. M., K.C.B., M.A., D.Se., F.R.S., Astronomer Royal.

Chrystal, G. C., F.R.S., Professor of Mathematies, University of Edinburgh.

Church, Arthur Herbert, M.A., D.Se., F.R.S., F.S.A., Professor of Chemistry, Royal Academy of Arts.

Clark, E. Krtson, M.A., M.Inst.C.E., President Leeds Philosophical Soeicty.

Clerk, Dugald, F.R.S., M.I.C.E., M.I.M.E., F.C.S., Seientifie Investigator and President of the Ineorporated Institution of Automobile Engineers.

Clifton, R. B., M.A., F.R.S., Professor of Experimental Philosophy, University of Oxford.

Coldite, J. Norman, F.R.S., Professor of Chemistry, University of London.

Colliss, Sir Willian, M.P., late Viec-Chaneellor University of London.

Courtney of Penwti, RT. Hon. Lord.

Cozens-Hardy, Rt. Hon. Sir Hrrbert H., Mr.A., LL.B., Master of the Rolls.

Crookes, Sir Wrlitam, D.Se., F.R.S., Forcign Secretary Royal Society.

Crossley, Arthur W., D.Se., Ph.D., F.R.S., Professor of Chemristry to the Pharmaeentical Society ; Seeretary Chem. Soc.

Dale, Dr. A. W. W., Vice-Chancellor of the University of Livernool.

Dallinger, Rev. William Hexry, LL.D., Se.D., F.R.S., Vice-President of the Royal Mieroseopie Society.

Darwin, Francis, F.R.S., M.A., LI.D., F.L.S., F.Z.S., President of the British Association.

Darwes, Sib Geobae H., K.C.B., M.A., F.R.S., Fellow of Trinity College; Plumian Professor of Astronomy, Cambridge. 
Darwix, Horace, M.A., F.R.S., Chairman of the Cambridge Scientific Instrument Co., Ltd. Dawkixs, IV. BoYn, M.A., D.Se., F.R.S., Hon. Professor of Geology, University of Manchester. Divers, EDward, M.D., D.Sc., F.R.S., Emeritus Professor of Chemistry in the Imperial University, Japan.

Dixon, Harold B., M.A., F.R.S., Professor of Chemistry in the University of Manchester, President of the Chemical Society, London, President Manchester Literary and Philosophical Society.

Dobbie, James J., M.A., D.Sc., LL.D., F.R.S., Dircetor of the Royal Scottish Muscum.

Donaldson, Srr James, Vice-Chaneellor and Prineipal of the University of St. Andrews.

Downing, A. M. W., M.A., D.Sc., F.R.G.S., F.R.S., Superintendent of the Nautical Almanac.

Draper, Cinarles Henry, B.A., D.Sc., Principal of the Municipal Technieal College, Brighton.

DundeLL, W., M.I.E.E., F.R.S., Elcetrieal Engincer.

Dyer, W. R. 'Tirseltox, K.C.B., F.R.S., Late Direetor of Royal Gardens, Kew.

Eutot, Sur Charles, Viee-Chaneellor of University of Sheffield.

Elis, H. Willoughay, F.I.S., F.E.S., President of Birmingham Philosophieal Society.

Ellis, William, F.R.S., F.R.A.S., Mem.Inst.Elee.Eng.

Esson, Williar, M.A., F.R.S., Savilian Professor of Geometry in the University of Oxford.

Fergus, Freelaxd, M.D., President of the Royal Philosophical Soeiety of Glasgow.

Festing, MLajor-Gex. E. Robert (late R.E.), C.B., F.R.S., Late Direetor of the (Scicnee) Vietoria and Albcrt Muscum.

Fletcher, Banxister, F.R.I.B.A., Architect.

Forster, M. O., D.Sc., Ph.D., F.R.S., Assistant Professor of Chemistry, Imperial Collcge of Scicnce and 'Tcehnology.

Forsytir, A. R., Se.D., LL.D., Matt.D., F.R.S., Fellow of Trinity College, Cambridge, Sudlerian Professor of Pure Mathematies in the University of Cambridge.

Frankland, Percy F., M.Sc., F.R.S., Professol of Chemistry, Birmingham University.

Fry, RT. Hon. Sir EDward, P.C., C.C.B., B.A.. LL.D., F.R.S., Fellow of the University of London, Hon. Fellow of Balliol College, Oxford.

Galton, Sir Francis, F.R.S., M.A., D.C.L., Se.D.

Gardiner, Walter M., M.Se., Professor of Chemistry, Teehnical College, Bradford.

Geikie, Sir Arcuibald, K.C.B., President of the Royal Soeiety.

Gilcirist, Percy C., A.R.S.M., M.I.C.E., M.I.M.E.. M.R.I., F.R.S., Metallurgist.

Gili, Sir David, K.C.B., LL.D., D.Se., F.R.S., Hon.F.R.S.F., F.R.G.S., President of the Royal Astronomical Society, formerly His Majesty's Astronomer at the Cape.

Glazebrook, R. T., M.A., F.R.S., Fellow of Trinity College, Cambridge; Director of the National Physieal Laboratory.

Goldine, F. G., Prineipal, City and Guilds Leather Trades School.

Gower, Williair, M.A., Prineipal of the Woolwich Polytechnie.

Gowland, W., F.R.S., A.R.S.M., Professor of Mctallurgy at the Royal Sehool of Mines, London.

Greenhili, G., M.A., F.R.S., Late Professor of Nathematics, Woolwich.

Griffirhs, E. H., Se.D., LI.D., F.R.S., Honorary Fellow of Sidncy College, Cambridge, Prineipal of University College of S. Wales and Monnrouthshire.

Groves, Charles, E., F.C.S.. F.C.I., F.R.S., Chemist.

GrubB, Sir Howard, F.R.S., F.R.A.S., Hon.M.A.I., University of Dublin, Vicc-President Royal Dublin Society; Astronomical Instrument Maker, Dublin.

Hamiton, Thomas, M.A., D.D , LL.D., Vice-Clancellor of Queen's University, Belfast.

Harris, Walter, M.A., Ph.D., Headmaster of Sutherland Technical Institute, Longton, Stoke-on-Trent.

Hartley, W. N., F.R.S., Professor of Chemistry, Royal College of Seience, Dublin.

Hel.e-Shaw, H. F., F.R.S., President of Institute Automobile Enginecrs.

Helrs, J. W., H.I.C.E., President Institution of Gas Engineers.

Hennesssey, J. B. N., C.I.E., M.A., I R.A.S., F.R.G.S., F.R.S., Late Deputy SurveyorGeneral of India.

Henrict, O., Ph.D , LL.D., F.R.S., Professor of Matlicmatics in the City and Guilds of London Central Teelinical College.

Hrll, M. J. M., M.A., Se.D., F.R.S., Viee-Chancellor of the University of London; Astor Professor of Pure Mathematies in the University of London.

Hopkinson, Alfred, K.C., M.A., Vice-Chancellor of the Vietoria University of Manehester.

Hooker, Sir Joseph, M.D., R.N., D.C.L., LL.D., G.C.S.I., C.B., F.R.S., Past President Royal Society.

Hudson, P. F., M.A., Prineipal Huddersfield Technical College.

Huggins, Sir Willia m, K.C.B., O.M., D.C.I., F.R.S., Past Piesident of the Royal Soeiety.

Hull, Enward, LL.D., M.A., F.G.S., F.R.S., Late Direetor of the Geological Survey of Ircland.

Huntington, WM., B.Sc., Principal L.C.C. Norwood Teelnical Institute.

Inalis, James C., President of Institution of Civil Engineers.

JAMre, Alfren, Past Prosident of Institutc of Mining and Metallurgy.

JAPP, F. R., M.A., LI.D., F.R.S., Professor of Chemistry in the University of Aberdeen.

JUDD, Johs W., C.B., LL.D., F.R.S., Late Professor of Geology, and Dean of the Royal College of Scienee. 
Joly, Jonn, F.R.S., Professor of Geology, Dublin.

Keane, Charles A., D.Se., Plr.D., F.I.C., Prineipal of the Sir John Cass Technieal Institute.

Kempe, A. B., M.A., F.R.S., Treasurer of the Royal society.

Kennedy, Sir Alexr, B. W., LL.D., D.Eng., F.R.S., Past President Institution of Civil Engincers ; Past President Institution of Mechanical Engineers.

Ker, J. Stuart, B.Se., Principal Westminster Technical Institute.

Kerr, I. Grairam, President of the Royal Physieal Society of Edinburgh.

Kipptia, F. Stanifex, D.Se., F.R.S., Professor of Chemistry, Nottingham.

Kirk, Sir Johx, G.C.II.G., K.C.B., M.D., D.C,L., F.R.G.S., Foreign Secretary Royal Geographical Society.

Kxowles, H. B., M.A., Headmaster, Royal Technieal Institute, Salford.

Lamb. Horace, Sc.D., LL.D., F.R.S., Professor of Mathematies in the University of Man. chester.

Larmor, Sir Josepir, M.A., D.Se., LI.D., F.R.S., Lueasian Professor of Mathematies, Cam. bridge ; Seeretary Royal Society.

Laurexce, Sir Trevol, Bart., President of the Royal Hortieultural Society.

Lees, Charles H., D.Sc., F.R.S., Professor of Plyysies in the Fast London College.

Lister, Time Rr. How. Lord, O.Mr., F.R.C.S., D.C.I., F.R.S., Past President Royal Society.

Livenac, G. D., M.A., I.R.S., Hon.Se.D., Formerly Professor of Chemistry in the University of Cambridge.

Liverstdge, A., M.A., LL.D., F.R.S., Emeritus Professor of Chemistry, University of Sydney, Australia.

Lodge, Sir Otrver, D.Se., LL.D., F.R.S., Prineipal of the University of Birmingham.

MacAlister, Sir Doxald, K.C.B., Prineipal of University of Glasgow.

MacGregor, J. G., D.Se., LL.D., F.R.S., Professor of Natural Philosophy, Edinburgh University.

MCKexDrICK, Joun G., M.D., LL.D., F.R.S., F.R.C.P.E., M.R.I., Emeritus Professor of Physiology, University of Glasgow.

McLeod, Herbert, LL.D., F.R.S., Formerly Professor of Chemistry, Royal Indian Engineering College, Cooper's Hill.

Macmanow, MaJor P. A., R.A., D.Se., F.R.S., General Seeretary, British Association for the Advaneement of Scienee.

Magrus, Srr Phimp, M.P., for the University of London.

Marshale, Hugm, D.Sc., F.R.S.E.. F.R.S., Professor of Chemistry, Dundee.

Martin, Charles J., M.D., D.Se., I.R.S.. Director of the Yister Institute.

Mason, Dr. A. J., Viee-Chaneellor of the University of Cambridge.

Matuer, Sir Willian, LL.D., Engineer.

MatThey, George, F.R.S., F.C.S.

Mrenola, Raphate, F.R.S., Professor of Cliemistry in the City and Ginilds Teelmieal College: Finsbury; Past President, Chemieal Society and Soeiety of Chemieal Industry.

Meldisir, Hexry, President, Royal Meteorologieal Society.

Miers, Hexry A., D.Se., F.R.S., Prineipal of the University of London.

Milis, Edrund J,, D.Sc., LL.D., F.R.S., Emeritus Professor of Teehnical Chemistry in the Glasgow and West of Seotland Technieal College.

Mrychir, E. A., M.A. Professor of Protozoology in the University of London; President, Quekett Mieroseopic Club.

Mond, Ludwia, Pl.D., F.R.S., Alkali Manufaeturer.

Mordey, W. M., President of the Institution of Electrieal Engineers.

Morana, C. Lloyd, LL.D., A.R.S.M., F.G.S.. F.R.S., Prineipal of University College, Bristol ; Vice-Chancellor of the University of Bristol.

Mowatt, Str Francts, G.C.B.

MüLter, Hugo, Ph.D., LL.D., V.P.C.S., F.R.S.

Momerx, J. C. S., A.R.I.B.A., President, Royal Photographie Society of Great Britain.

Murray, Sir Jonn, K.C.B., F.R.S., D.Se., LL.D., ete., formerly Editor of the "Challenger" Reports.

Newali, H. F., M.A., F.R.S.. Professor of Astro-Physies, Cambridge.

NewTon, A. J., Prineipal, L.C.C. Sehool of Photo-Engraving and Lithography.

Niven, C., M.A., D.Se., F.R.S., Professor of Natural Philosophy, University of Aberdeen.

Noble, Sir Anorew, BarT., K.C.B., F.R.S., D.C.L., D.Se., Se.D.

Nortiumberlayd, Duke OF, K.G., F.R.S., President, Royal Institution.

Odinge, Wiltram, M.A., M.B., Hor.Ph.D., F.R S., F.R.C.P., Waynflete Professor of Chemistry, University of Oxford.

Oster, Wilutam, M.D., F.R.C.P., F.R.S., Regius Professor of Nedicine, Oxford.

Parker. J. Gordor, Pl..D. Principal of Leathersellers' Teehnical College.

Parratt, Sir WaLter, M.A.. Mus. Doc., Master of the King's Musicke ; Professor of Munsie in the University of Oxford.

Parsons, Hon. C. A., C.B., F.R.S., LI.D., Sc.D., M.I.C.E., Engineer, Viee-President I.N.A., Hon. Member M.I.E.E.

Pedler, Sir Alexander, C.I.E., F.R.S., F.I.C., Formerly Vice-Chancellor of the University of Caleutia.

Perkix, A. G., F.R.S., F.R.S.E., F.I.C., F.C.S., Lecturer in the University of Leeds. 
Perkix, M. H., Ph.D., M.Se., F.R.S., Professor of Chemistry in the University of Manchester. Perry. John, D.Se., LL.D., F.R.S., Professor of Mechanies and Mathematics, Royal College of Scicnee; Past President, Physical Socicty.

Petavel, J. E., F.R.S., Professor of Engincering, University of Manchester.

PICKerivg, Spexcer, M.A., F.C.S., F.I.C., F.R.S., Director of the Wobum Experinnental Fruit Farm.

PopE, IILLAA. J.. M.A., F.R.S., Professor of Clemistry in the University of Cambridge.

PoYNTIxg, J. H., Se.D., F R.S., J.P., Professor of Physics. Univensity of Birmingham.

Preece, Sir Willam, K.C. B.. F.R.S., Past President of the Institution of Civil Enginecrs and of the Institution of Electrieal Engineers.

Pordik, Tromas, B.Sc., Ph.D., LL.D., F.R.S., Emeritus Professor of Chemistry, University of St. Andrews.

Ramsay, Sir Whlian. K.C.B., Ph.D., LL.D., Se.D., F.R.S., Professor of Chemistry in the University of London (University College).

Ruwsos, S. G., D.Se. F.I.C., Principal of the Battersea Polytechnic.

RAYleigh, RT. How. Lord, O.M., M.A., D.C.L., LL.D., T.R.S., Past President Royal Society; Chaneellor of the University of Cambridge.

Reinold, A. W., M.A., F.R.S., Late Professor of Physies in the Royal Naval College, Greenwieh.

RENDEL, LORD.

Reycolns, J. Emerson, M.D., Sc.D., Formerly Plofessor of Chemistry, 'Irinity College, Dublin ; Ex-President, Society of Chemieal Industry.

Reynombs, J. H., M.Sc., Prineipal of the Municipal School of 'Technology, Manchester.

Roscoe, Sir Hevry, D.C.L., LL.D., F.R.S., Emeritus Professor of Chemistry, Manchester University.

RosEbery, E.ARI, OF, K.G.. Chancellor of the University of London.

RüCKer, Sir Artilur, M.A., D.Sc.. LL.D., F.R.S., 'I'rustee of the British Association, and formerly Secretary of the Royal Society, formerly President of the British Association; formerly Prineipal of the University of London.

Russell, W. J.. F.R.S., Chemist.

Rutherford, E.. M.A., D.Sc., LL.D., F.R.S., Professor of Physies, Universily of Manchester.

Schuster, Arturu, Ph.D., D.Sc. Se.D., F.R.S., Hon. Professol of Physies, University of Manchester; President of the International Association of Seismology; Chairman of the Exeeutive Committee of the International Union for Solar Researeh.

Scott, Alexander, F.R.S., Sc.D., D.Se., Superintendent of the Davy Faraday Rescareh Laboratory of the Royal Institution; Treasurer of the Chemienl Society.

SeLL, W. J., M.A., Se.D., F.R.S.. F.I.C.. University Leeturer in Chemistry, Cambridge.

Sinw, W. N., F.R.S., Se.D., LL.D., Reader in Meteorology in the University of London Direetor of the Meteorologieal Office.

Sherringtox, Charles S., M.A., M.D.. D.Sc., LL.D., F.R.S., Professol of Physiology in the University of Liverpool.

Shurlock. Fredk. W.r., B.A., B.Sc., Prineipal, Derby Technical Collecre.

SHUTTLEWORTH, LORD.

Sifmexs, Alfixañe, Vice-President Institution of Civil Engineers.

Skinner, Sidner, M.A., Prineipal of the S.W. Polytechnie Institute, Chelsea.

Smrti, Sir Swire, J.P., Viee-Chaiman, Royal Commission on International Exhibitions.

Smtimelis, Artuur, B.Se., F.I.C., li.R.S., Professor of Chemistry, University of Leeds.

Starling, Ernest H., M.D.. F.R.S., Jodrell Professor of Physiology. University of Jondon.

STEAD, J. F.. F.R.S., F.I.C., Consulting Chemist. Niddlesbrough.

Stirlisa, RT. Hox. Sir James, M.A., Ll.D.. F.R.S., late Lord Justice of Appeal.

Strutt. Hox. R. J., M.A., F.R.S., Professor of Physics, Imperial College of Seience and 'Technology.

Sutclifee, JonN H.. F.R.S.L., President Optical Society; Secretary Blitish Optical Association.

Swax, Sir Joseph Wirsox, D.Se., M.A., F.C.S., F.I.C., F.R.S.

SWINBURNE. James, Eleetrieal Engineer.

'Tarleton, Francis E., President of the Royal Irish Aeademy.

Treck. H.S.H., THE Deke of, President of the Royal Botanie Society.

'Irompson, Sylvayus P., B.A., D.Se., M.D. F.R.A.S., F.R.S.. Prineinal of and Professor of Physies in the City and Guilds Teehnieal College, Finsbury; Past: President of the Institution of Eleetrieal Engineers; Past President of the Physieal Society of London.

Thomsox, Sir Joserir, M.A., D.Se., Se.D., LL.D., Ph.D., F.R.S.. Fellow of Trinity College, and Cavendish Professor of Experimental Physies, Cambridge; President-Elect of the British Association.

Thomson, John MlliaAr, LI.D., F.R.S., Professor of Chemistry. King's College, London; Dean of the Faculty of Seienee. University of London.

Thorsycroft, Sir Johx 1., F.R.S., L.L.D.. M.I.C.E., Member of Couneil M.I.M.E. ; VioePresident I.N.A.

Thorpe, Sir Tromas E., C.B., D.Se. Sc.D.. Ph.D., LL.D., F.R.S., Late Prineipal of the Government Laboratories; Professor of Chemistry. Imperial College of Seicnec and Technology. 
Threltall, Richard, F.R.S., Chemical Nanufacturer.

Tídin, Willaw A., D.Sc., F.R.S., Fellow of the University of London; Professor of Chemistry in the Imperial College of Seienee and 'Technology.

I'raill, Anthosy, LL.D., MI.D, D.L. for Co. Antrim, Provost of 'l'rinity College, Dublin.

Turner, H. H., E.R.S., D.Se., D.C.L., Corresponding Member of the Institute of France; Savilian Professor of Astronomy in Oxford University.

Torver, Sir Whliam, K.C.B., M.B., D.C.L., LL.D., Sc.D., F.R.C.S., F.R.S.E., F.R.S., Principal and Vice-Chancellor of University of Edinburgh.

Iwelverress, W. NobI.E, M.I.M.E., M.R.S.I., A.M.I.E.E., President of the Civil and Mechanieal Enginecr's' Society.

Unwix, II. C., B.Se., LL.D., M.I.C.E. F.R.S., Emeritus Professor of Engineering at the Central 'Technieal College of the City and Guilds of London Institute.

Wat.ker, James. LL.D., D.Se., Ph.D., F.R.S., Plofessor of Chemistry, University of Edin. burgh.

WARD, Jonx, J.P., President, Institution Engineers and Shipbuilders in Seotland.

Warrex, 'T. Hrabert, Hon. D.C.L. Viee-Chancellor of the University of Oxford.

Watsox, W., D.Se., F.R.S. Assistant Professol of Physies in the Royal College of Seienee, London.

Wertinemer, J., B.Se. B.A.. E.I.C.. F.C.S., Principal of the Merehant Venturers' Technical College, Bristol.

White, Sir Mildani, K.C.T3.. LL.D., Se. D.. W. R.S.. Viee-President, Institute Naval Arehitects.

Whitéker, EDMuND 'I., F.R.S. Royal Astronomer of Ireland.

WILDF, Hexry, D.Se., D.C.L.. F.R.S., Engineer.

Wilscs, Haroln A., M.A., D.Se., M.Se., F.R.S., Professor of Physies, King's College, London.

Wilson, Joseph Wuslad, M.L.C.E., M.T.M.E., Prineipal of the Crystal Palace Sehool of Practical Engineering.

Wolfe-Barry, Sin Johy, K.C.B., Ll.D., F.R.S., Ex-President I.C.E.

Woon, Sir Henry Truemax. Secretary of the Royal Society of Arts.

Worthincitox, A. MI., C.B., M.A.. F.R.S., Professor of Physies, Royal Naval Engineeering College. Devonport.

Wynje, Willam Palmer, D.Se., F.I.C., F.R.S., Firth Professor of Chemistry in the University of Shefficld.

Young, J. Rymer, F.C.S., Ex-President of the Pharnaeeutical Society.

Younc, Sidnfy, D.Se., Se.D., F.C.S., F.R.S.. Professor of Chemistry, 'Trinity College, Dublin. 


\section{APPENDIX M.}

Account of the Cash Receipts and Payments of the Commissioners For the Exhibition of 1851, fron 1st Jantari, 1889, to 31st December, 1910. 


\section{APPENDIX M.}

\section{Abstracti of the Cash Receipts and Payments of the Royal Commissioners}

\section{RECEIPTS}

To Babance at 1st Tamary, 1889, per last Account- see Appendix "IF" to the Seventh Report of the Conr. missioners (page 89)

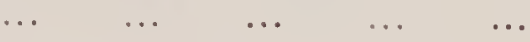
$\ell^{2}$
s. $d$.

"LAND sol.1)

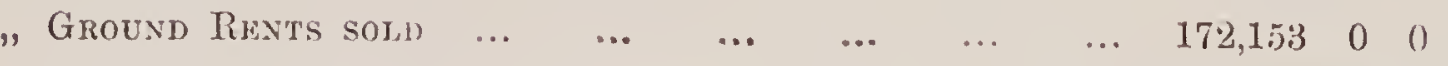

"Rists RECEIVED...

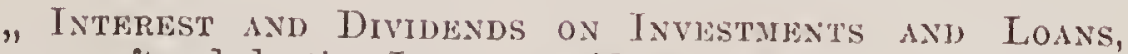
after dedueting Interest paid on moneys borrowed from the 13ank of England

"Mischllangous Richipts

We have exanined the above Abstract of the Cash Receipts and Pryments of the Royal 1889, and ending 31 st. December, 1910, with the Statements of Accounts issued at the end of each ycar

During the first three year's, from 1st January, 1889, to 31st December, 1891, the Commissioners' ninetecn years to 31 st December, 1910, the Commissioner's' Accounts have been audited by ourselves.

5 London Wall Buildings, Finsbury Cirens, E.C. 24th February, 1911. 
(see Report, page 28).

For the Exhibirion of 1851, rrom 1st .J Anuary, 1889, to 31st December, 1910.

\section{PAYMENTS}

By Bank of Exglain to extingmish Loans

"Grants for Educational Purposes:-

Science Rescarch Scholarships and Bursaries...

Imperial Institute Research Laboratory ... . ...

Royal College of Music $\quad \ldots \quad \ldots \quad \ldots$

National Association for Promotion of Technical and

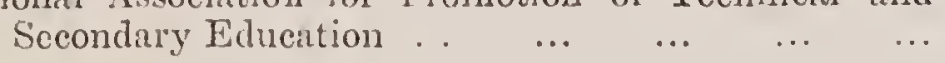

" Improvenexts to Estatk axp Bulldigs, Structural Alterations to the Exhibition Galleries, Laying

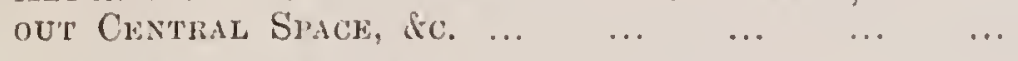

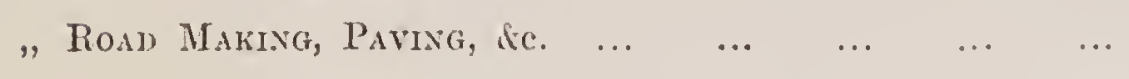

, Royal Albert Hall:-

Seat Rate after dedueting Income received from letting $\begin{array}{llllllll}\text { seats } & \ldots & \ldots & \ldots & \ldots & \ldots & \ldots & \ldots\end{array}$

Construction of New Sonth Entrance, 1898

Further Works on New Sonth Entrance, including Construction of Vaults, 1906-1909 * (see notc bclow) ... $\quad \ldots \quad 3,505 \quad 0 \quad 0$

Less Amount repaid by Royal Albert Hall Corporation

\begin{tabular}{llll}
$\cdots$ & 500 & 0 & 0 \\
\hline
\end{tabular}

s s. d.

$£ \quad s . d$.

$134,325 \quad 0 \quad 0$

$43,809 \quad 19 \quad 3$

\section{$21,607 \quad 16 \quad 6$ \\ $7,566 \quad 0 \quad 0$}

$3,005 \quad 0 \quad 0$

$32,178 \quad 16 \quad 6$

$20,000 \quad 0 \quad 0$

"Aupance to Royal School of Art Needework bearing interest at 3 per cent.

"Salaries, kc., including Examiners' Fees in connection with Science Research Scholarships $\quad \ldots \quad \ldots \quad \ldots$

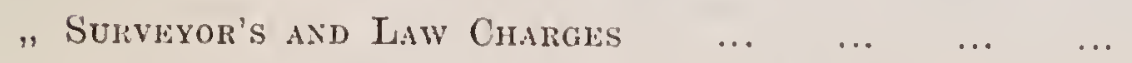

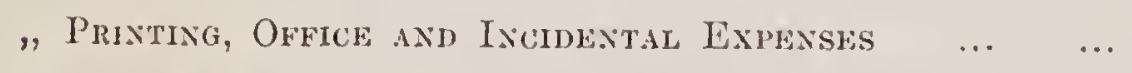

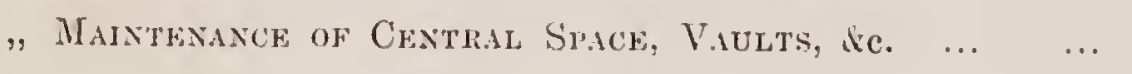

"Investruexts Purciased, as detailed on page 150...

"BaLance at 31st Decembcr, 1910, viz.:-

$\begin{array}{llllllllll}\text { Cash at Bank of Jingland } & \ldots & \ldots & \ldots & \ldots & \ldots & 10,392 & 3 & 1\end{array}$

$\begin{array}{lllllllllll}\text { Cash in hand } & \ldots & \ldots & \ldots & \ldots & \ldots & \ldots & & 8 & 14 & 4\end{array}$

$36,972 \quad 10 \quad 6$

$245,39211 \quad 8$

$20,582 \quad 4 \quad 9$

$\begin{array}{lll}10,559 & 7 & 4\end{array}$

$3,426 \quad 14 \quad 7$

$2,404 \quad 3 \quad 10$

$10,40017 \quad 5$

* NoTE. - Threc-fifths of the cost $(23,505)$ of the further works in connection with the Ncw South Entrance, amounting to $\ell^{2}, 103$, has been treated as an advance to the Royal Albert Hall, repayable in five ammal instalments, the first of which, annoming to t500, was repaid in January, 1910. (S'e itcm in Statcment of Assets and Liabilitics, page 148.)

Commissioner's for the Exhibition of 1851 for the period of twenty-two years, commencing 1st January, throughont that period, and we certify the above Abstract to be correct and in accordance therewith. Accounts werc certified by an ofticer appointed by the Bank of England, and during the remaining 


\section{ASSE'TS}

CASH, INVKSTMINTS, LOANS, EC.:-

1. Cash on Current Accomnt at the Bank of England,

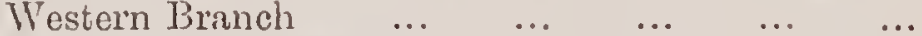

2. Cash on Deposit at Bank of England, Westem Branch

3. Petty Cash in hand

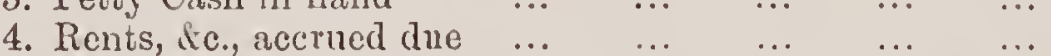

5. Royal Albert Hall, balanec of advance to Corporation of $\{2,103$, bearing interest at 4 per cent. per annum, being their proportion of Expenditure on works at South Entrance, repayable in five annual instalinents (the first of which, amomiting to $2^{\prime} 500$, was repaid in January, 1910)

6. Royal School of Art Needlework, advances for the construction of the new School Building, bearing interest at 3 per cent. per annum (secured by lease

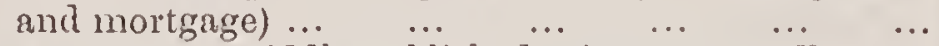

7. Investments at middle published prices on 31st Decem. ber, 1910, as detailed on page $150 \quad \ldots \quad \ldots \quad$...

Kensington Gore Estate, valued on basis of Mr. Hripy A. Hunt's Valuation of 17ru Jusk, 1889:-

8. Albert Hall Mansions, leased at ground rents amounting to $£ 3,150$ ( 30 years' purchase)

9. Houses, Nos. 11 to 16 Kensington Gore, leased for term expiring in 1928, at ground rents amounting to $亡 87$, ineluding the reversion to the rack rents ... ...

10. Houses, Nos. 17 to 24 Kicnsington Gore, and stables, let on leases, at rents amounting to 1,830

11. Houses in Quecn's Gate, from comel of Kensington Gore to Prince Consort Road, with stables behind, and threc other stables in Jay Mews, leased at ground rents amounting to $£ 2,884$ (33 ycars' $\begin{array}{lllllllll}\text { purchase }) & \ldots & \ldots & \ldots & \ldots & \ldots & \ldots\end{array}$

12. Houses in Queen's Gate, south of Prince Consort Road, leased at ground rents amounting to 1740.58 . (30

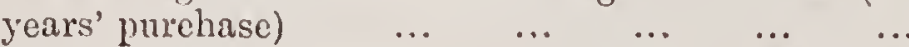

13. Land in Jay Mews, leased at a ground rent of $£ 250 \mathrm{per}$ annum (30 ycars' purchase) $\ldots \quad \ldots \quad \ldots \quad \ldots$

14. Houses and stables ontside main square, leased at ground rents amounting to $\_604 \mathrm{per}$ annum (averacre 35 years' purchase)

15. Plot of land behind 180 Qucen's Gate, leased at 210 per annum (say 20 years' purchase)

16. Land in Exhibition Road, leased to Royal School of Art Needlework at a ground rent of 2200 per anmum

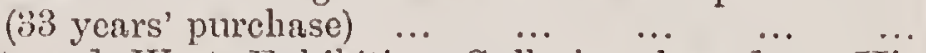

17. East and West Exhibition Galleries, leased to His Majesty's Commissioners of Works for 50 years from 1891, at $£ 3,654$ per annum, reduced during the year 1910 owing to the surrender of the Northern end of the East Gallerics (sce item 21), to $£ 2,934$ per annum (30 years' purchase)

18. Vaults under land south of Royal Albert Häl, leased at $\$ 310$ per annum (20 years' purchase)

$\begin{array}{rrr}\mathcal{L} & \text { s. } & d \\ & & \\ 1,392 & 3 & 1 \\ 9,000 & 0 & 0 \\ 8 & 14 & 4 \\ 3,473 & 7 & 7\end{array}$

$1,603 \quad 0 \quad 0$

$20,000 \quad 0 \quad 0$

$204,252 \quad 0 \quad 0$

$239,729 \quad 5 \quad 0$

$94,500 \quad 0 \quad 0$

7,551000

$27,895 \quad 0 \quad 0$

$95.172 \quad 0 \quad 0$

$22,207 \quad 10 \quad 0$

$7,500 \quad 0 \quad 0$

$21,140 \quad 0 \quad 0$

$200 \quad 0 \quad 0$

$6,600 \quad 0 \quad 0$

$88,020 \quad 0 \quad 0$

$6,200 \quad 0 \quad 0$

$376,98510 \quad 0$

Assits Which caniot Br considered Pealisable:-

19. Land in Exhibition Roal between Central Technieal College and Prince Consort Road, and

20. Land south of Royal Albert Hall and north of Imperial Institute

21. East Exhibition Galleries, Northern End, to be leased to the Imperial College of

22. Ground rents of Imperial Institute, Royal Albert Hall, Contral Technical College, Royal

We eertify the correctness of the Cash, the Investments, the outstanding Rentals, and the other values attached to the Kensington Gore Estate, amounting in total to 1376,98510 s., arc based on be in their possession. 'The amount of each liability above noted is properly stated. 
(see Report, page 29).

Commissioners for the Exhibition of 1851-31st Dreenier, 1910.

\section{LIATILITIES}

1. Maintenance of Buildings and Central Space

is. d.

$2215 \quad 5$

5) 169

2. Maintenance of Roads

3. Law Charges ontstanding

4. Surveyor's Charges outstanding

5. Enginecr's Charges outstanding

6. Miscellaneous

$5812 \quad 2$

$\begin{array}{lll}150 & 0 & 0\end{array}$

$\begin{array}{lll}52 & 10 & 0\end{array}$

9170

$\$ 299 \quad 11 \quad 4$

Balange, ming the Estrmated Surplus of Reatisable Assits over

LTABILITRLS ...

leased to the Imperial College of Science and Technology for 999 years from October 1909 at a ground rent of $f 5$ per ammum.

Science and Technology.

Colloge of Music, Royal College of Organists, and Alexandra House, 219. 2s. per annum.

Asset Balances, whose total amounted to 2239,72958 . on 31st December, 1910. The estimated a valuation made in 1889 , and the Title Deeds relating thereto are certified by the Solicitors to 
Investments Held BY the Comaisstoners at 31st Deghemer; 1910.

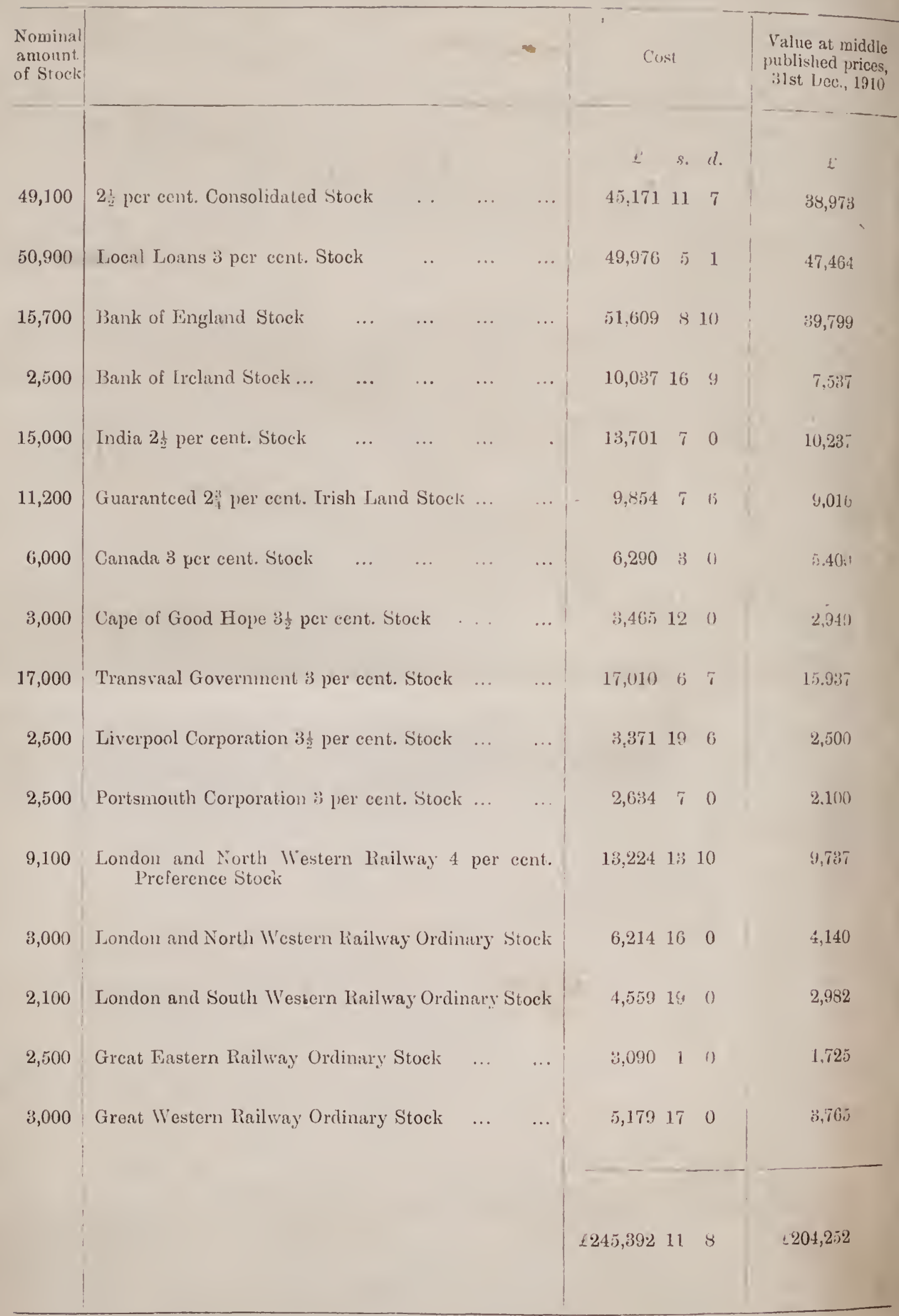


COPY OF PIAN

ATTACHED TO 3RD REPORT DATED 1856

OF IANDS

ORIGINALLY PURCHASED BY THE COMMISSIONERS FOR THE EXHIBHTION OF 1851
P A R K

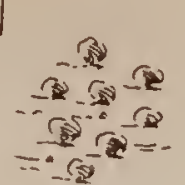

Site of the

Great Exhibition Building 1851

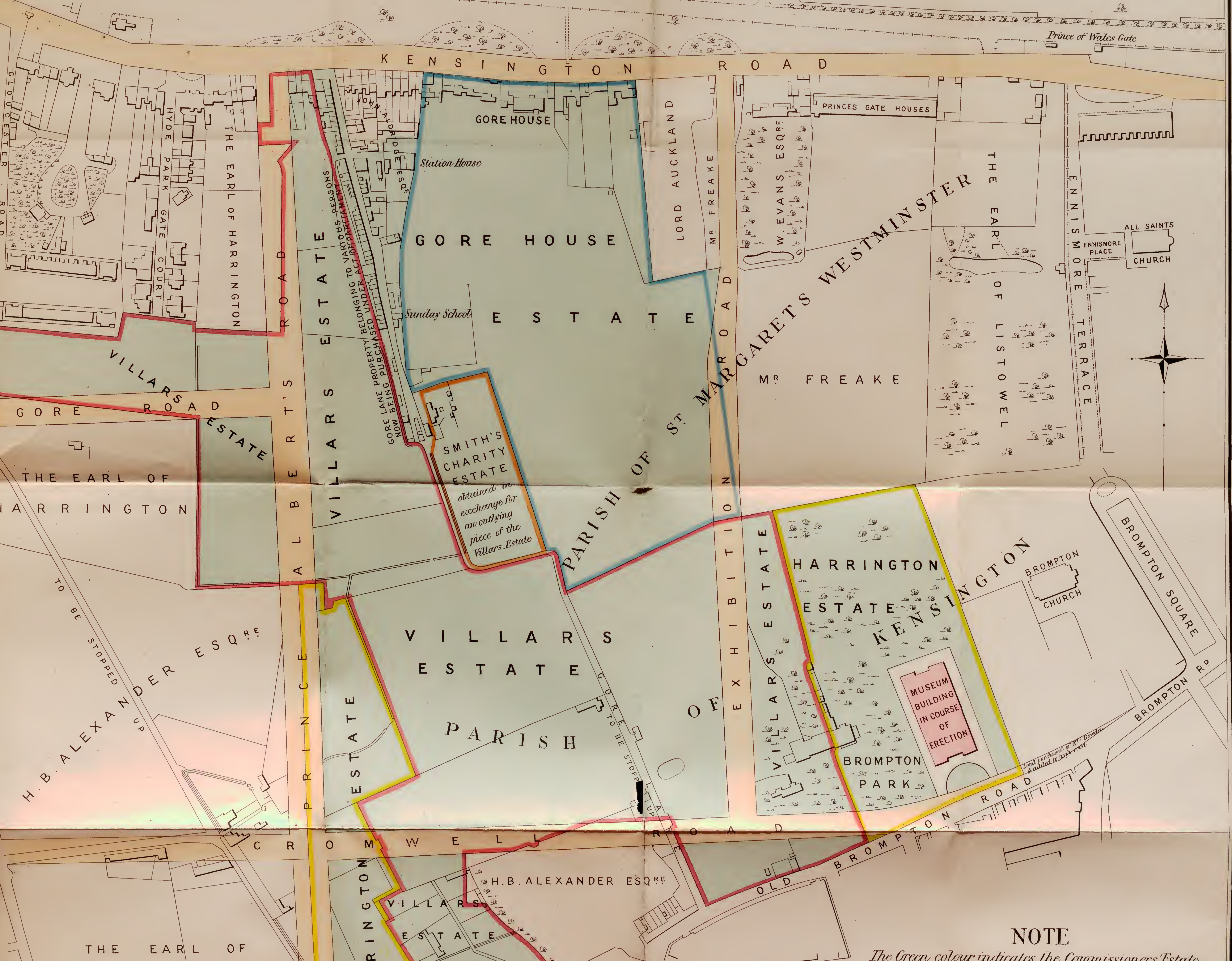



(n) 




\section{EIGHTH LEPORT}

\section{THE COMMISSIONERS}

ENi? TII:

EXHTBITIU OK KA.

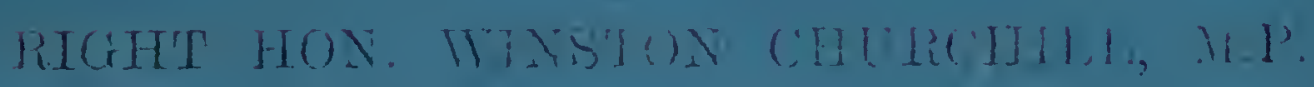

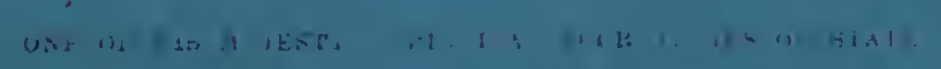

1. ONDUN:

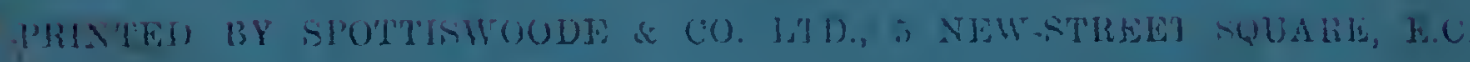

